In cooperation with Northern Arizona University and Utah State University

\title{
2008 Weather and Aeolian Sand-Transport Data from the Colorado River Corridor, Grand Canyon, Arizona
}

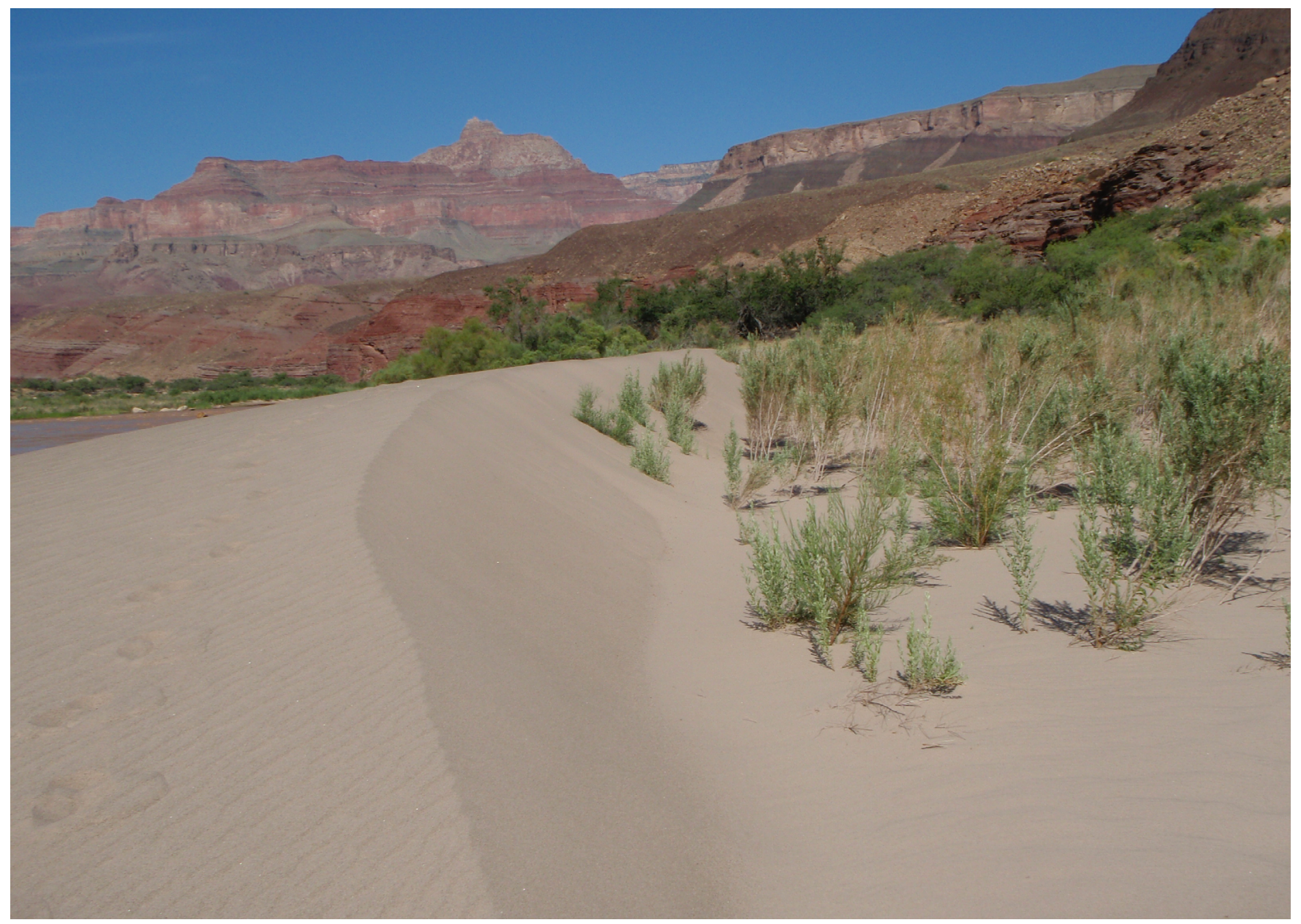

Open-File Report 2009-1190 
Cover: Photograph taken on July 30, 2008, of an aeolian dune formed from sand reworked along the Colorado River below Glen Canyon Dam after the March 2008 high-flow experiment (USGS photograph by Amy Draut). 


\section{Weather and Aeolian Sand-Transport Data from the Colorado River Corridor, Grand Canyon, Arizona}

By Amy E. Draut, Hoda A. Sondossi, Joseph E. Hazel, Jr., Timothy Andrews, Helen

C. Fairley, Christopher R. Brown, and Karen M. Vanaman

Open-File Report 2009-1190 


\title{
U.S. Department of the Interior \\ KEN SALAZAR, Secretary
}

\author{
U.S. Geological Survey \\ Suzette M. Kimball, Acting Director
}

U.S. Geological Survey, Reston, Virginia: 2009

For product and ordering information:

World Wide Web: http://www.usgs.gov/pubprod

Telephone: 1-888-ASK-USGS

For more information on the USGS--the Federal source for science about the Earth, its natural and living resources, natural hazards, and the environment:

World Wide Web: http://www.usgs.gov

Telephone: 1-888-ASK-USGS

Any use of trade, product, or firm names is for descriptive purposes only and does not imply endorsement by the U.S. Government.

Although this report is in the public domain, permission must be secured from the individual copyright owners to reproduce any copyrighted materials contained within this report.

Suggested citation:

Draut, A.E., Sondossi, H.A., Hazel, J.E., Jr., Andrews, T., Fairley, H.C., Brown, C.R., and Vanaman, K.M., 2009, 2008 Weather and aeolian sand-transport data from the Colorado River corridor, Grand Canyon, Arizona: U.S. Geological Survey Open-File Report 2009-1190, 98 p. 


\section{Contents}

Abstract
Introduction.
Project Objectives
Methods.
Monitoring Weather Parameters
Monitoring Aeolian Sediment Transport
AZ C:13:0006 C:13:0336
AZ C:13:0321
AZ C:13:0346
AZ B:11:0281
AZ A:15:0033
AZ G:03:0072

\section{Figures}

1. Colorado River corridor through Grand Canyon, Ariz., showing approximate locations of

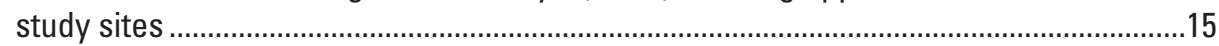

2. Photograph of instrument station near AZ A:15:0033 .............................................................16

3. Photographs of the sandbar near AZ C:05:0031 before and after the 2008 high-flow experiment

4. Surveyed profiles of the sandbar near AZ C:05:0031, in Grand Canyon, Ariz., before and after the 2008 high-flow experiment

5. Aerial photograph of the area around AZ C:05:0031, in Grand Canyon, Ariz., with arrow indicating net direction of potential aeolian sediment transport measured at AZ C:05:0031 L in 2008

6. Magnitude and direction of wind velocity measured at the instrument station AZ C:05:0031 L in the Colorado River corridor, Grand Canyon, Ariz., at 4-minute resolution throughout 2008

7. Cumulative 2008 rainfall record measured at $A Z$ C:05:0031 L in the Colorado River corridor, Grand Canyon, Ariz

8. Wind, aeolian sand-transport, and rainfall data collected at the instrument station AZ C:05:0031 L in the Colorado River corridor, Grand Canyon, Ariz., in 2007 and 2008. 
9. Temperature, humidity, and barometric pressure data collected at the instrument station $A Z$ C:05:0031 L in the Colorado River corridor, Grand Canyon, Ariz., in 2007 and 2008..........23

10. Aerial photograph of the area around AZ C:05:0031, in Grand Canyon, Ariz., with arrow indicating net direction of potential aeolian sediment transport measured at AZ C:05:0031 $\mathrm{U}$ in 2008

11. Magnitude and direction of wind velocity measured at the instrument station AZ C:05:0031 $\mathrm{U}$ in the Colorado River corridor, Grand Canyon, Ariz., at 4-minute resolution throughout 2008.

12. Cumulative 2008 rainfall record measured at AZ C:05:0031 U in the Colorado River corridor, Grand Canyon, Ariz. 26

13. Wind, aeolian sand-transport, and rainfall data collected at the instrument station $A Z$ C:05:0031 U in the Colorado River corridor, Grand Canyon, Ariz., in 2007 and 2008.........27

14. Temperature, humidity, and barometric pressure data collected at the instrument station AZ C:05:0031 U in the Colorado River corridor, Grand Canyon, Ariz., in 2007 and 2008...28

15. Photographs of the sandbar near AZ C:13:0365 before and after the 2008 high-flow experiment

16. Photograph of an aeolian dune near AZ C:13:0365 that formed on sand deposited by the March 2008 high-flow experiment.

17. Surveyed profiles of the sandbar near AZ C:13:0365 before and after the 2008 high-flow experiment.

18. Aerial photograph of the area around AZ C:13:0365, in Grand Canyon, Ariz., with arrow indicating net direction of potential aeolian sediment transport measured at AZ C:13:0365 L in 2008 .

19. Magnitude and direction of wind velocity measured at the instrument station AZ C:13:0365 $L$ in the Colorado River corridor, Grand Canyon, Ariz., at 4-minute resolution throughout 2008

20. Cumulative 2008 rainfall record measured at AZ C:13:0365 L in the Colorado River corridor, Grand Canyon, Ariz

21. Wind, aeolian sand-transport, and rainfall data collected at the instrument station $A Z$ C:13:0365 L in the Colorado River corridor, Grand Canyon, Ariz., in 2008

22. Temperature, humidity, and barometric pressure data collected at the instrument station AZ C:13:0365 L in the Colorado River corridor, Grand Canyon, Ariz., in 2008 ....................36

23. Aerial photograph of the area around AZ C:13:0365, in Grand Canyon, Ariz., with arrow indicating net direction of potential aeolian sediment transport measured at AZ C:13:0365 $\mathrm{U}$ in 2008

24. Magnitude and direction of wind velocity measured at the instrument station AZ C:13:0365 $\mathrm{U}$ in the Colorado River corridor, Grand Canyon, Ariz., at 4-minute resolution throughout 2008 ...

25. Cumulative 2008 rainfall record measured at AZ C:13:0365 U in the Colorado River corridor, Grand Canyon, Ariz.

26. Wind, aeolian sand-transport, and rainfall data collected at the instrument station $A Z$ C:13:0365 U in the Colorado River corridor, Grand Canyon, Ariz., in 2007 and 2008 40

27. Temperature, humidity, and barometric pressure data collected at the instrument station AZ C:13:0365 L in the Colorado River corridor, Grand Canyon, Ariz., in 2007 and 2008....41

28. Photograph of the sandbar near AZ C:13:0006 after the 2008 high-flow experiment.............42

29. Surveyed shore-perpendicular profiles of the sandbar near AZ C:13:0006 before and after the 2008 high-flow experiment

30. Aerial photograph of the area around AZ C:13:0006, in Grand Canyon, Ariz., with arrow indicating net direction of potential aeolian sediment transport measured in 2008 
31. Magnitude and direction of wind velocity measured at the instrument station AZ C:13:0006

in the Colorado River corridor, Grand Canyon, Ariz., at 4-minute resolution in 2008.......45

32. Cumulative 2008 rainfall record measured at AZ C:13:0006 in the Colorado River corridor, Grand Canyon, Ariz.

33. Wind, aeolian sand-transport, and rainfall data collected at the instrument station AZ C:13:0006 in the Colorado River corridor, Grand Canyon, Ariz., in 2007 and 2008 . .47

34. Temperature, humidity, and barometric pressure data collected at the instrument station AZ C:13:0006 in the Colorado River corridor, Grand Canyon, Ariz., in 2007 and 2008.......48

35. Photographs of the sandbar near AZ C:13:0336 before and after the 2008 high-flow experiment

36. Aerial photograph of the area around AZ C:13:0336, in Grand Canyon, Ariz., with arrow indicating net direction of potential aeolian sediment transport measured at AZ C:13:0336 $\mathrm{U}$ in 2008

37. Magnitude and direction of wind velocity measured at the instrument station AZ C:13:0336

$\mathrm{U}$ in the Colorado River corridor, Grand Canyon, Ariz .....................................................51

38. Cumulative 2008 rainfall record measured at AZ C:13:0336 U.............................................52

39. Wind, aeolian sand-transport, and rainfall data collected at the instrument station $A Z$ C:13:0336 U in the Colorado River corridor, Grand Canyon, Ariz., in 2007 and 2008, and sand-transport data collected at AZ C:13:0336 L in 2008.

40. Temperature, humidity, and barometric pressure data collected at the instrument station AZ C:13:0336 U in the Colorado River corridor, Grand Canyon, Ariz., in 2007 and 2008...54

41. Photographs of the sandbar near AZ C:13:0321 before and after the 2008 high-flow experiment.

42. Surveyed shore-perpendicular profiles of the sandbar near AZ C:13:0321 before and after the 2008 high-flow experiment

43. Aeolian sand-transport data collected near AZ C:13:0321 in 2008

44. Aerial photograph of the area around AZ C:13:0346, in Grand Canyon, Ariz., with arrow indicating net direction of potential aeolian sediment transport measured at AZ C:13:0346 L in 2008

45. Magnitude and direction of wind velocity measured th the instrument station AZ C:13:0346

$\mathrm{L}$ in the Colorado River corridor, Grand Canyon, Ariz.

46. Cumulative 2008 rainfall record measured at AZ C:13:0346 L

47. Wind, aeolian sand-transport, and rainfall data collected at the instrument station $A Z$ C:13:0346 L in the Colorado River corridor, Grand Canyon, Ariz., in 2007 and 2008

48. Temperature, humidity, and barometric pressure data collected at the instrument station AZ C:13:0346 L in the Colorado River corridor, Grand Canyon, Ariz., in 2007 and 2008....62

49. Aerial photograph of the area around AZ C:13:0346, in Grand Canyon, Ariz., with arrow indicating net direction of potential aeolian sediment transport measured at instrument station AZ C:13:0346 U in 2008.

50. Magnitude and direction of wind velocity measured at the instrument station AZ C:13:0346 $\mathrm{U}$ in the Colorado River corridor, Grand Canyon, Ariz., at 4-minute resolution throughout 2008 .

51. Cumulative 2008 rainfall record measured at $A Z \mathrm{C}: 13: 0346 \mathrm{U}$

52. Wind, aeolian sand-transport, and rainfall data collected at the instrument station $A Z$ C:13:0346 U in the Colorado River corridor, Grand Canyon, Ariz., in 2007 and 2008 66

53. Temperature, humidity, and barometric pressure data collected at the instrument station AZ C:13:0346 U in the Colorado River corridor, Grand Canyon, Ariz., in 2007 and 2008...67 
54. Aerial photograph of the area around the instrument station near AZ B:11:0281, in Grand Canyon, Ariz., with arrow indicating net direction of potential aeolian sediment transport measured in 2008

55. Magnitude and direction of wind velocity measured th the instrument station AZ B:11:0281 in the Colorado River corridor, Grand Canyon, Ariz., at 4-minute resolution throughout 2008

56. Cumulative 2008 rainfall record measured at AZ B:11:0281

57. Wind, aeolian sand-transport, and rainfall data collected at the instrument station $A Z$

B:11:0281 in the Colorado River corridor, Grand Canyon, Ariz., in 2007 and 2008

58. Temperature, humidity, and barometric pressure data collected at the instrument station AZ B:11:0281 in the Colorado River corridor, Grand Canyon, Ariz., in 2007 and 2008 .....72

59. Aerial photograph of the area around the instrument station near AZ A:15:0033, in Grand Canyon, Ariz., with arrow indicating net direction of potential aeolian sediment transport measured in 2008

60. Magnitude and direction of wind velocity measured the instrument station AZ A:15:0033 in the Colorado River corridor, Grand Canyon, Ariz., at 4-minute resolution throughout 2008

61. Cumulative 2008 rainfall record measured at AZ A:15:0033

62. Wind, aeolian sand-transport, and rainfall data collected at the instrument station $A Z$ A:15:0033 in the Colorado River corridor, Grand Canyon, Ariz., in 2007 and 2008

63. Temperature, humidity, and barometric pressure data collected at the instrument station AZ A:15:0033 in the Colorado River corridor, Grand Canyon, Ariz., in 2007 and 2008 ......77

64. Aerial photograph of the area around the instrument station near AZ G:03:0072, in Grand Canyon, Ariz., with arrow indicating net direction of potential aeolian sediment transport measured at AZ G:03:0072 U in 2008.

65. Magnitude and direction of wind velocity measured at the instrument station AZ G:03:0072 $\mathrm{U}$ in the Colorado River corridor, Grand Canyon, Ariz., at 4-minute resolution throughout 2008.

66. Cumulative 2008 rainfall record measured at $A Z \mathrm{G}: 03: 0072 \mathrm{U}$

67. Wind, aeolian sand-transport, and rainfall data collected at the instrument station $A Z$ G:03:0072 U, and aeolian sand-transport data collected in sand traps at AZ G:03:0072 L, in the Colorado River corridor, Grand Canyon, Ariz., in 2007 and 2008

68. Temperature, humidity, and barometric pressure data collected at the instrument station AZ G:03:0072 U in the Colorado River corridor, Grand Canyon, Ariz., in 2007 and 2008...82

\section{Tables}

1. Approximate river miles, station names, abbreviations, and equipment deployed at each study site, month in which the station was established, and setting of aeolian dunes at

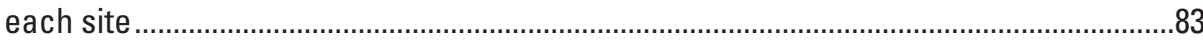

2. Total rainfall, in $\mathrm{mm}$, recorded daily at each of the weather stations... 84

3. Vector sums of the sediment-transport proxy variable, $Q p$, by month for each weather station

4. Area and volume of sand above the $226 \mathrm{~m}^{3} / \mathrm{s}\left(8,000 \mathrm{ft}^{3} / \mathrm{s}\right)$ stage on sandbars near sites monitored for this project. 


\title{
2008 Weather and Aeolian Sand-Transport Data from the Colorado River Corridor, Grand Canyon, Arizona
}

\author{
By Amy E. Draut, ${ }^{1}$ Hoda A. Sondossi, ${ }^{2}$ Joseph E. Hazel, Jr., ${ }^{3}$ Timothy Andrews, ${ }^{4}$ Helen C. Fairley, ${ }^{2}$ Christopher \\ R. Brown, ${ }^{3}$ and Karen M. Vanaman ${ }^{3}$
}

\begin{abstract}
This report presents measurements of weather parameters and aeolian (windblown) sand transport made in 2008 near selected archaeological sites in the Colorado River corridor through Grand Canyon, Ariz. The quantitative methods and data discussed here form a basis for monitoring ecosystem processes that affect archeological-site stability. Combined with forthcoming work to evaluate landscape evolution at nearby archaeological sites, these data can be used to document the relationship between physical processes, including weather and aeolian sand transport, and their effects on the physical integrity of archaeological sites. Data collected in 2008 reveal eventand seasonal-scale variations in rainfall, wind, temperature, humidity, and barometric pressure. Broad seasonal changes in aeolian sediment flux are also apparent at most study sites.

The continuation of monitoring that began in 2007, and installation of equipment at several new sites in early 2008, allowed evaluation of the effects of the March 2008 high-flow experiment (HFE) on aeolian sand transport. At two of the nine sites studied, spring and summer winds reworked 2008 HFE sandbars to form new aeolian dunes, at which sand moved inland toward larger, well-established dune fields. At the other seven study sites, neither dune formation nor enhanced sand transport after the HFE were observed. At several of those sites, dominant wind directions in spring 2008 were not oriented such that much HFE sand would have moved inland; at other sites, lack of increased inland sand flux is attributable to lack of sandbar enlargement near the study sites or to inhibition of sand movement by vegetation or local topography.
\end{abstract}

\section{Introduction}

This report summarizes high-resolution measurements of wind speed and direction, rainfall, air temperature, barometric

\footnotetext{
${ }^{1}$ U.S. Geological Survey, Santa Cruz, Calif.

${ }^{2}$ U.S. Geological Survey, Flagstaff, Ariz.

${ }^{3}$ Northern Arizona University, Flagstaff, Ariz.

${ }^{4}$ Utah State University, Logan, Utah.
}

pressure, and relative humidity made during 2008 at weather stations operated by the U.S. Geological Survey's (USGS) Grand Canyon Monitoring and Research Center within the Colorado River corridor through Grand Canyon, Ariz. Sand traps deployed near each weather station collect aeolian (windblown) sand, from which daily sand-transport rates are estimated. These stations provide the only meteorological record available from the interior of Grand Canyon, apart from daily temperature and rainfall measurements made by the National Park Service (NPS) at Phantom Ranch, near river mile 88 and rainfall measurements recorded near river mile 60 and near river mile 225 by researchers from Utah State University in 2006 and $2007 .^{1}$

During March 6-9, 2008, a high-flow experiment (HFE) occurred in Grand Canyon, involving a 60-hour release of $1,160 \mathrm{~m}^{3} / \mathrm{s}\left(41,000 \mathrm{ft}^{3} / \mathrm{s}\right)$ from Glen Canyon Dam that was intended to rebuild sandbars in the Colorado River corridor. This was the third such experimental flow; the earlier two occurred in March 1996 (Webb and others, 1999) and November 2004 (Topping and others, 2006). Some of the sandbars rebuilt by the HFEs are source areas from which windblown sand moves inland to replenish aeolian sand dunes. Aeolian movement of sand following HFEs is important because some dune fields in Grand Canyon contain archaeological sites that depend on a supply of windblown sand to remain covered and preserved (Neal and others, 2000; Thompson and Potochnik, 2000; Draut and others, 2008). In addition to reporting weather data, this report discusses area and volume changes at sandbars nearest to the weather stations and evaluates effects of the 2008 HFE on aeolian sand movement around these study sites. More detailed discussion of the effects of the 2004 HFE on aeolian sand in the Colorado River corridor through Grand Canyon, and associated management implications, can be found in Draut and Rubin (2008).

\footnotetext{
${ }^{1}$ Locations in the river corridor are commonly referred to by their distance, in miles, downstream from Lees Ferry, Ariz. (fig. 1). This report follows that convention and uses the International System of Units for other measurements. River miles used here are those provided by the World Wide Web map server operated by the Grand Canyon Monitoring and Research Center: http:// www.gcmrc.gov/products/ims/ims.htm, accessed August 13, 2009. However, in keeping with the legal requirement for Federal agencies not to disclose sensitive archaeological site locations, river miles cited in this report are approximate.
} 
This report follows Draut and Rubin (2008) in referring to aeolian sand deposits as belonging to one of two types: modern fluvial sourced (MFS) and relict fluvial sourced (RFS) deposits. The two types are distinguishable by their position relative to modern fluvial sandbars (those that formed at river flows of $1,270 \mathrm{~m}^{3} / \mathrm{s}$ or less) that could have provided windblown sand. MFS dune fields are situated directly downwind of active (postdam) fluvial sandbars and formed as the wind moved sand inland from those sandbars, creating dune fields. RFS deposits, in contrast, formed as wind reworked sediment from older (predam), higher-elevation flood deposits, forming aeolian sand dunes from sediment left by floods that were larger than any postdam floods have been. RFS dunes may receive some sand from modern sandbars if the wind blows from upwind sandbars at times, but their major source of sand is older deposits left by floods with flows greater than 1,270 $\mathrm{m}^{3} / \mathrm{s}$.

\section{Project Objectives}

The primary objective of the cultural-resource research and development monitoring project is to develop objective, replicable, quantitative methods for monitoring ecosystem processes affecting archaeological-site stability in the Colorado River corridor in Grand Canyon, Ariz. This monitoring effort uses sufficient spatial and temporal resolution to document the relationship between physical landscape processes, including weather and aeolian sediment transport, and the physical integrity of archaeological sites. Objectives specific to the weather-monitoring component of this project include (1) evaluating the utility and practicality of employing Vaisala transmitters for high-resolution monitoring of local weather conditions in the remote, logistically challenging environment of inner Grand Canyon; (2) evaluating spatial and temporal variability of weather parameters measured throughout the Colorado River corridor in Grand Canyon; and (3) evaluating effects of weather and sediment transport on the physical condition of archaeological sites in the Colorado River. An additional objective, (4), specific to the work conducted in 2008, was to apply the methods being tested in the cultural-monitoring research and development project to evaluate the effects of the experimental high flow release from Glen Canyon Dam on downstream resources (sandbars, aeolian dunes, and sensitive archaeological areas). In particular, we wanted to determine whether changes in the size of sandbars created during the high-flow event would, under dry and windy weather conditions, result in increased sediment transport and an accumulation of sand cover at appropriately situated archaeological sites. This report concentrates primarily on reporting results related to objectives 2 and 4. Objective 1 was addressed in a previous publication (Draut and others, 2009), and objective 3 is the subject of continuing research.

The physical processes represented by data collected in this study include seasonal weather cycles (of wind intensity, humidity, barometric pressure, and precipitation patterns) and storm events with daily or hourly time scales. The rainfall and aeolian sand-transport rates measured in 2008 and reported here will be used in future reports to evaluate processes responsible for observed landscape change documented at nearby archaeological sites using terrestrial light detection and ranging, or lidar, and total-station surveys (for example, Collins and Kayen, 2006; Collins and others, 2008, 2009).

High-resolution weather data, when combined with high-resolution topographic surveys, form one basis from which to assess potential or measured effects of Glen Canyon Dam operations on archaeological sites in the Colorado River corridor (Fairley and Sondossi, 2008). Data presented in this report provide a basis for comparison with aeolian sand-transport regimes measured at some of the same sites in years preceding the March HFE. These results will help to address the question of whether, and under what specific weather conditions, enlarging fluvial sandbars (by high-flow dam operations) increases the amount of sand moved inland by wind toward dunes and archaeological sites. Additionally, when compiled into decadal-scale records, weather data such as these can also be used to identify regional climatic trends. Given that the Colorado River Basin has experienced more warming during recent years than other areas of the United States (Saunders and others, 2008), records such as these should prove valuable to a range of ecosystem studies during the coming years.

\section{Methods}

Since early 2007, instrument stations have operated near seven archaeological sites in the Colorado River corridor indicated on figure 1: AZ C:05:0031, AZ C:13:0006, AZ C:13:0336, AZ C:13:0346, AZ B:11:0281, AZ A;15:0033, and AZ G:03:0072. In February 2008, two additional instrument stations were deployed near AZ C:13:0365 (AZ C:13:0365 L and U), and new sets of sand traps were deployed near AZ C:13:0321 and AZ C:13:0336 (AZ $\mathrm{C}: 13: 0336 \mathrm{~L})$ to collect data relevant to the March 2008 HFE. Each "instrument station" consists of one weather station and one set of sand traps (specifications are discussed below). At AZ C:05:0031, AZ C:13:0365, and AZ C:13:0346, two instrument stations operate approximately $80 \mathrm{~m}$ apart at each site, to resolve differences in weather and aeolian sand transport that occur with elevation and distance from the river. At AZ C:13:0336 and AZ G:03:0072, one additional set of sand traps is present approximately $40 \mathrm{~m}$ closer to the river than the full instrument station. Table 1 lists all station locations by approximate river mile, along with the equipment operating at each site in 2008, names used for each station in this report, and the general setting of each dune field (whether MFS, RFS, or other type).

Study sites were chosen to provide data relevant to the condition and stability of nearby archaeological sites 
where topographic surveys were planned (Collins and others, 2008; O'Brien and Pederson, 2008). Instrument stations were deployed in the vicinity of archaeological sites but not near enough to disturb any cultural features or artifacts; sites were selected and equipment installed with input from NPS archaeologists. Several of the study sites were chosen because of their apparent responsiveness to experimental sandbar-building flows in 1996 and 2004 (Draut and Rubin, 2006). These sites were retained in the present study to extend weather records at these locations and to be able to compare results from previous experimental flows with the March 2008 HFE. Sites were also selected to be distributed along the river corridor between upper Marble Canyon (approximately river mile 25) and the western canyon (approximately river mile 225) to record spatial variations in weather patterns throughout the river corridor.

At five of the study sites upstream of river mile 70 (AZ C:05:0031, AZ C:13:0365, AZ C:13:0006, AZ C:13:0336, and AZ C:13:0321), dimensions of river-level sandbars nearest to the instrument stations were surveyed several weeks before and several weeks after the March HFE to evaluate area and volume changes caused by the high flow. Survey methods used were the same as those described by Hazel and others (2008a). In addition, sandbar topography was surveyed before and after the HFE at these same sites to determine whether sand derived from sandbars moved inland toward areas containing archaeological sites. Of the four study sites not surveyed, one does not have a nearby sandbar under the modern dam-controlled flow regime (AZ C:13:0346), and the others have ephemeral sandbars nearby but could not be surveyed within the restricted time frame of the field work just before the HFE (AZ B:11:0281, AZ A:15:0033, and AZ G:03:0072).

\section{Monitoring Weather Parameters}

Specifications of the weather stations were established and fine-tuned during 2007; details of equipment design and modifications made for use in Grand Canyon were discussed by Draut and others (2009). All weather stations used for this study are configured identically and consist of a transmitter and data logger mounted on a tripod (fig. 2). The transmitter, a Vaisala $^{\mathrm{TM}}$ multiparameter weather transmitter, model WXT510 with serial data interface SDI-12, is mounted at a height of $2 \mathrm{~m}$ above ground level. The data logger is a Nexsens ${ }^{\mathrm{TM}}$ iSIC logger upgraded to $2 \mathrm{MB}$ memory. The system is powered by an Optima D34/78 deep-cycle 12 V battery (AGM type, $55 \mathrm{Ah}$ ) housed in a box on the ground and charged by a south-facing 30-watt, 12 VDC solar panel mounted on the tripod. Solar panels are the BPSX3OU model made by BP Solar, modulated by a SK-6 Morningstar Solar 12 VDC, 6A controller.

The manufacturer's stated measurement range for wind speed measured by the Vaisala WXT510 sensor is $0-60 \mathrm{~m} / \mathrm{s}$, with accuracy $\pm 0.3 \mathrm{~m} / \mathrm{s}$ or \pm 3 percent, whichever is greater, for wind speed $0-35 \mathrm{~m} / \mathrm{s}$. For wind speed $36-60 \mathrm{~m} / \mathrm{s}$, accuracy is \pm 5 percent. The measurement range for wind direction is $360^{\circ}$, with an accuracy of $\pm 3^{\circ}$. We assume an additional $5^{\circ}$ margin for error incurred by the user when aligning the transmitter with true north, for a total estimated accuracy range on wind direction of $\pm 8^{\circ}$. The transmitter has an estimated response time of $250 \mathrm{~ms}$ for detecting wind speed and direction. We record wind speed and direction at 4-minute intervals, with each data point consisting of the 4-minute averaged wind speed and direction, as well as the speed and direction of the highest gust during each 4-minute interval (gust speed measured as 3-second average).

A pressure sensor on the Vaisala WXT510 transmitter detects liquid rainfall with resolution of $0.01 \mathrm{~mm}$ and 5 percent accuracy according to the manufacturer. Rainfall is recorded on the data logger at 4-minute intervals as 4-minute total amount. Air temperature, relative humidity, and barometric pressure are recorded by a separate sensor within the shaded housing of the WXT510 unit. The measurement range on air temperature is from -52 to $+60^{\circ} \mathrm{C}$ with accuracy at $20^{\circ} \mathrm{C}$ of $\pm 0.3^{\circ} \mathrm{C}$. Relative humidity $(\mathrm{RH})$ ranges from 0 to 100 percent, with accuracy of \pm 3 percent within $0-90$ percent $\mathrm{RH}$ and \pm 5 percent within $90-100$ percent $\mathrm{RH}$. The sensor measures barometric pressure with a measurement range of $600-1100$ mbar, with accuracy of $\pm 0.5 \mathrm{mbar}$ at $0-30^{\circ} \mathrm{C}$ and \pm 1 mbar below $0^{\circ} \mathrm{C}$ or above $30^{\circ} \mathrm{C}$. Temperature, relative humidity, and barometric pressure are recorded on the data logger at 4-minute intervals as 4-minute averages.

Weather stations are camouflaged using paint and burlap to reduce their visibility to Grand Canyon National Park visitors and are equipped with signs explaining their purpose in the event that visitors approach them. Stations were visited for maintenance and data downloading every 12 to 18 weeks during 2008. Transmitters from each station were replaced during 2008 and sent to Vaisala for calibration; all were found to have been operating within the manufacturer's stated accuracy ranges during 2008 with the exception of the sensor removed from station AZ C:13:0006 in October 2008, which had failed to record accurate wind data for several months (spurious wind data collected at AZ C:13:0006 have been omitted from this report).

\section{Monitoring Aeolian Sediment Transport}

Aeolian sediment transport is monitored at each study site using wedge-shaped, galvanized metal "big spring number eight" (BSNE) passive-sampling sand traps (Fryrear, 1986). Sand traps are emptied during maintenance visits to the instrument stations every 6 to 18 weeks. Therefore, sediment-transport measurements are based on cumulative values representing the interval between visits. Sediment samples are collected from traps in the field and brought back to a laboratory at Northern Arizona University in Flagstaff, Ariz., to be weighed. Organic material is removed from the sediment by treating the samples with hydrogen peroxide. Samples are then dried overnight in an oven at $80^{\circ} \mathrm{C}$, allowed to cool in a desiccant chamber, and weighed on scale with precision to $0.0001 \mathrm{~g}$. 
This study uses BSNE traps in sets of four deployed on a vertical pole, with the orifices of the four traps set at heights of $0.1,0.4,0.7$, and $1.0 \mathrm{~m}$ above the ground (fig. 2). Each trap is equipped with a vane that turns the trap into the wind. The BSNE design is used widely in agricultural and geologic studies of windblown sediment, in part, because its shape allows it to perform nearly isokinetically, causing minimal distortion of air flow at the sampling orifice (Stout and Fryrear, 1989; Nickling and McKenna Neuman, 1997; Zobeck and others, 2003). The sampling orifice measures $5 \mathrm{~cm}$ tall by $2 \mathrm{~cm}$ wide; air flow enters the trap through the orifice and exits through a 60-mesh screen in the upper surface of the trap. Sediment is retained in the lower half of the trap after falling through a wider (18-mesh) screen. Wind-tunnel studies (Goossens and others, 2000) indicate an efficiency range of 70 to 130 percent for BSNE sand traps for the wind velocities and sediment grain sizes encountered in Grand Canyon. Efficiency less than 100 percent indicates that air flow is directed away from the orifice, such that the trap undersamples windblown sediment, whereas efficiency greater than 100 percent indicates that air flow is directed into the trap, oversampling windblown sediment. We use the efficiency range of 70 to 130 percent to estimate error in the sand-transport data reported here. This conservative treatment of the data is the best available for the bulk sand-transport data reported here; the exact correspondence between wind velocities and local sand-transport rates is unknown.

To represent the sand-transport potential for a given wind velocity, we use a proxy variable, $Q p$, which is defined as:

$$
Q p=\left(u-u_{\text {crit }}\right)^{3}
$$

The relation in equation (1) follows the convention used to construct aeolian-sediment-transport models, such as those of Kawamura (1951) and Lettau and Lettau (1977) but substitutes wind velocity for shear velocity. Although the units of $Q p\left(\mathrm{~m}^{3} /\right.$ $\mathrm{s}^{3}$ ) do not translate directly to a sand flux, the $Q p$ value for each site over a given time interval serves as a proxy indicating potential for sand transport. $Q p$ was calculated for all the data points at which the wind velocity $(u)$ exceeded the critical threshold of motion $\left(u_{c r i t}\right)$. The critical threshold of motion is taken to be $2 \mathrm{~m} / \mathrm{s}$ based on sediment grain size measured for these study sites and other surficial sediment deposits in Grand Canyon (Bagnold, 1941; see Draut and Rubin, 2005, 2008). For the data points at which $u<_{u c r i t}, Q p$ was set equal to zero, indicating that no sand transport would occur. Dominant wind directions causing sand transport were then calculated by using vector sums of $Q p$ values from the 4-minute wind measurements. Vector-sum calculations were also made after eliminating wind measured within 48 hours after a rainfall event, the amount of time (based on field observations at different times of year) after which sand is generally sufficiently dry to be mobilized by wind.

\section{Results}

Weather and aeolian sand-transport data from each station are discussed in detail below. Table 2 shows daily rainfall recorded at each weather station during 2008. Vector sums of aeolian sand-transport potential, listed by month at each station, are shown in table 3. $Q p$ vector sums for dry conditions are shown in table $3 B$.

Table 4 lists changes in sandbar area and volume for the five study sites that were surveyed before and after the March 2008 HFE.

\section{Site-Specific Data}

The following sections describe the setting of each weather station, any problems with instrument performance, and site-specific findings from 2008. The station numbers reference nearby archaeological sites and are presented in geographic order, starting with the farthest upstream station and proceeding downstream.

\section{AZ C:05:0031}

Two weather stations operated throughout 2008 in an aeolian dune field on the downstream side of a debris fan at the AZ C:05:0031 site—one near river level (AZ C:05:0031 L) and one at the upper end of the dune field (AZ C:05:0031 U). Neither station experienced equipment malfunctions in 2008. A fluvial sand deposit occurs at the riverward (western) side of this dune field. The fluvial sandbar area increased 1 percent and its volume increased 8 percent as a result of the March 2008 HFE (table 4; figs. 3, 4). Between March and October 2008, during summer daily flow fluctuations, the sandbar at this site lost 33 percent of its area and 6 percent of its volume (table 4).

The dune-field area between the two weather stations at AZ C:05:0031 undergoes active sand transport and has moderate vegetation and little biologic soil crust. An approximately equal area at the north (upstream) end of the dune field is relatively inactive, with well-developed soil crust and evident deflation of the land surface. Draut and Rubin (2008) identified this dune field as a MFS aeolian sediment deposit, based on observations between 2003 and 2006 of net sediment-transport potential from the direction of a river-level sandbar. However, some of the sand in this area was apparently deposited by predam floods and by exceptionally high postdam flows in 1983-84, based on its topographic position relative to modeled water-surface elevations (Magirl and others, 2008) and the presence of a penny, dated 1981, found embedded in a fluvial deposit a short distance upstream of the weather station $A Z$ C:05:0031 L. A vector sum of all available wind data from AZ C:05:0031 L in 2008 yields a net $Q p$ magnitude of $32,164 \mathrm{~m}^{3} / \mathrm{s}^{3}$ from a direction of $174^{\circ}$; using wind data only from when the 
sand is estimated to have been dry, a vector sum yields a net $Q p$ magnitude of $26,995 \mathrm{~m}^{3} / \mathrm{s}^{3}$ from a direction of $169^{\circ}$ (fig. 5 ). These calculations indicate net sand transport toward the river and upstream, although, a directional wind plot shows no strong directional component at AZ C:05:0031 L (fig. 6). This contrasts with net potential sand transport toward the eastnortheast that was measured from 2003 to 2006 at this location (Draut and Rubin, 2008) but is similar to what was measured in 2007 (Draut and others, 2009).

The total annual rainfall measured at AZ C:05:0031 L in 2008 was $189.7 \mathrm{~mm}$ (table 2); cumulative rainfall data for this station are shown on figure 7. All weather parameters and sand transport measured at AZ C:05:0031 L in 2008 are summarized in figures 8 and 9, with 2007 data shown for comparison.

A vector sum of all available wind data from station AZ $\mathrm{C}: 05: 0031 \mathrm{U}$ (approximately $80 \mathrm{~m}$ inland and uphill of AZ C:05:0031 L) in 2008 yields a net $Q p$ magnitude of $82,308 \mathrm{~m}^{3} /$ $\mathrm{s}^{3}$ from a direction of $211^{\circ}$; using wind data only from when the sand is estimated to have been dry, a vector sum yields a net $Q p$ magnitude of $76,494 \mathrm{~m}^{3} / \mathrm{s}^{3}$ from a direction of $215^{\circ}$ (fig. 10). These calculations indicate net sand transport generally toward upstream, although, like the lower station, the directional wind plot (fig. 11) shows no strong directional component at AZ C:05:0031 U. As at the lower station, this upstream-directed net potential sand transport contrasts with a more northeastward net transport measured from 2003 to 2006 but is similar to what was measured in 2007 (Draut and others, 2009).

Total annual rainfall measured at AZ C:05:0031 U was $193.2 \mathrm{~mm}$ (table 2); cumulative rainfall data for this station are shown on figure 12. All weather parameters and sand transport measured at AZ C:05:0031 U in 2008 are summarized in figures 13 and 14, with 2007 data shown for comparison.

As observed previously at this site, wind velocities are typically higher at station AZ C:05:0031 U than at station AZ C:05:0031 L, attributed to lower vegetation densities at the upper site compared with the lower site. Aeolian sand-transport rates measured at AZ C:05:0031 U are correspondingly higher also (figs. 8, 13). At both the upper and lower station, the greatest sand-transport rates in 2008 occurred in the spring (April-June, year days 110-160), as is commonly observed at eastern Grand Canyon sites (Draut and Rubin, 2005, 2006; Draut and others, 2009), although an October event (year days 275-285) also caused substantial sand transport at AZ C:05:0031 U (fig. 13).

Consistently windy winter weather in late 2007 into early 2008 (year day 330 of 2007 to year day 35 of 2008; figs. 8, 13) was accompanied by substantial rainfall (table 2; figs. 8 , 13, and humidity plots in figs. 9 and 14), which apparently suppressed windblown sand movement. At both stations (AZ $\mathrm{C}: 05: 0031 \mathrm{~L}$ and $\mathrm{U})$, aeolian sand-transport rates were not discernibly higher in spring 2008 (after the HFE) than in spring 2007 given the error margin assigned to these data.

\section{AZ C:13:0365}

Two instrument stations were deployed near AZ C:13:0365 on February 9, 2008, to measure weather parameters and aeolian sand transport in relation to the March 2008 HFE. These two stations, AZ C:13:0365 L and AZ C:13:0365 $\mathrm{U}$, are situated in approximately the same places as those used near this site by Draut and Rubin (2008) when studying the November 2004 high flow. The area around AZ C:13:0365 includes an active aeolian dune field on the downstream side of a side canyon and associated debris fan; sand-transport rates within this dune field were the highest of any sites measured by Draut and Rubin (2008). Dune morphology there includes north-facing slip faces, consistent with northward dune migration; this, together with dominantly south-southeast winds measured by Draut and Rubin (2008), identify this as a MFS dune field whose primary sediment source is a fluvial sandbar immediately upwind of the dune field. A second sandbar, across the river and approximately $200 \mathrm{~m}$ downstream, also occasionally provides minor amounts of sediment to the dune field near AZ C:13:0365 (Draut and Rubin, 2008).

The sandbar near AZ C:13:0365 lost 17 percent of its area but gained 14 percent more volume as a result of the March 2008 HFE (table 4; fig. 15). Between March and October 2008, during summer daily flow fluctuations, the sandbar at this site gained 38 percent more area but lost 3 percent of its sand volume (table 4), a discrepancy that may be attributable to cutbank collapse. As of July 2008, it was observed that a new aeolian dune approximately $1 \mathrm{~m}$ high had formed on the HFE-deposited sandbar (fig. 16). The orientation and morphology of the new aeolian dune indicated transport inland, toward the north and into the larger aeolian dune field. Topographic surveys in February, April, and October 2008 indicated that, over the summer of 2008, sand from the HFE sandbar had moved inland such that by October, the highest elevation of the new sand deposit was $10 \mathrm{~m}$ inland and $1 \mathrm{~m}$ higher than its April position (profile 2 in fig. 17), consistent with wind reworking of HFE sand to form the aeolian dune shown in figure 16. The surveyed profiles in figure 17 also indicate substantial erosion of the outer (riverward) part of the sandbar over the summer of 2008, presumably caused by daily flow fluctuations.

A vector sum of all available wind data from AZ C:13:0365 L in 2008 (beginning on February 9) yields a net $Q p$ magnitude of $45,383 \mathrm{~m}^{3} / \mathrm{s}^{3}$ from a direction of $152^{\circ}$; using wind data only from when the sand is estimated to have been dry, a vector sum yields a net $Q p$ magnitude of $40,262 \mathrm{~m}^{3} / \mathrm{s}^{3}$ from a direction of $158^{\circ}$ (fig. 18). These calculations indicate net sand transport toward the north-northwest and upstream, although, the directional wind plot (fig. 19) shows that substantial transport from the north-northwest can also occur at AZ C:13:0365 L. This is consistent with net potential sand 
transport measured from 2003 to 2006 at this site (Draut and Rubin, 2008).

Total rainfall measured at AZ C:13:0365 L (beginning

when the station was deployed on February 9) was $263.7 \mathrm{~mm}$; cumulative rainfall during 2008 at this station is plotted on figure 20. All weather parameters and sand transport measured at AZ C:13:0365 L in 2008 are summarized in figures 21 and 22. Sand-transport rates were highest at AZ C:13:0365 L during spring 2008 (fig. 21); the daily sand-transport rates of about 4 $\mathrm{g} / \mathrm{cm}$ measured in May were approximately four times higher than spring sand transport rates measured near AZ C:13:0365 L during spring 2005, following the 2004 HFE (Draut and Rubin, 2008).

A vector sum of all available wind data from AZ $\mathrm{C}: 13: 0365 \mathrm{U}$ (approximately $50 \mathrm{~m}$ inland and uphill of $\mathrm{AZ}$ C:13:0365 L) in 2008 yields a net $Q p$ magnitude of 858,790 $\mathrm{m}^{3} / \mathrm{s}^{3}$ from a direction of $142^{\circ}$; using wind data only from when the sand is estimated to have been dry, a vector sum yields a net $Q p$ magnitude of $151,870 \mathrm{~m}^{3} / \mathrm{s}^{3}$ from a direction of $146^{\circ}$ (fig. 23). These calculations indicate net sand transport generally toward upstream, with higher wind speeds and a stronger southeasterly directional component than at the lower-elevation station AZ C:13:0365 L, although strong winds also come from the northwest at times (fig. 24). The wind velocities and dominant direction from the southeast at AZ C:13:0365 U are consistent with wind conditions measured here between 2003 and 2006 (Draut and Rubin, 2008) and would move sand inland from the HFE-deposited sandbar into the active MFS dune field.

Total rainfall measured in 2008 (beginning when the station was deployed on February 9) $295.2 \mathrm{~mm}$ at AZ C:13:0365 $\mathrm{U}$; cumulative rainfall is plotted on figure 25 . It is notable that the upper station at this site appeared to have recorded substantially more rain than the lower station (a difference of $31.6 \mathrm{~mm}$, or 12 percent). This is likely because the pressure sensor on the Vaisala transmitter at the upper site was recording windblown sand striking the sensor rather than raindrops; most of the apparent difference in rainfall between those two stations occurred between March and late May (table 2), when spring winds were causing substantial aeolian sand transport (sand-transport rates are substantially higher at the upper station than at the lower station at AZ C:13:0365; transport of sand in suspension to heights $>2 \mathrm{~m}$ has been observed many times in this and other Grand Canyon dune fields). The inability of the sensor to distinguish between the impact of raindrops and windblown sand would affect data integrity the most at sites with the greatest sand transport, that is, at AZ C:13:0365 $\mathrm{U}$ and at AZ C:13:0346 L (discussed below).

All weather parameters and sand transport measured at AZ C:13:0365 U in 2008 are summarized in figures 26 and 27.

\section{AZ C:13:0006}

The instrument station near AZ C:13:0006 is on the upstream side (with respect to the Colorado River) of an ephemeral tributary streambed on a small debris fan. At the instrument site, aeolian sediment is present but is interspersed with rocks and sparse vegetation; areas of open sediment in the vicinity of the weather station and sand traps are largely covered by well-developed biologic soil crust. The sandbar nearest to AZ C:13:0006 lost more than 12 percent of its area during the March 2008 HFE but gained almost 14 percent more volume (table 4; figs. 28, 29). Between March and October 2008, this sandbar gained 5 percent more area but lost 9 percent of its volume, a combination likely attributable to the collapse and partial erosion (by the river) of sand from cutbanks.

The Vaisala sensor at AZ C:13:0006 malfunctioned in 2008 such that wind speed and direction data between March and October, when the transmitter was replaced, were unreliable and are not reported here. A vector sum of usable wind data from the weather station at AZ C:13:0006 in 2008 yields a net $Q p$ magnitude of $10,999 \mathrm{~m}^{3} / \mathrm{s}^{3}$ from a direction of $115^{\circ}$; using data only from when the sand is estimated to have been dry, a vector sum yields a net $Q p$ magnitude of $6,419 \mathrm{~m}^{3} / \mathrm{s}^{3}$ from a direction of $127^{\circ}$ (fig. 30).

Wind speed and direction measured at AZ C:13:0006 (excluding March-October data) are plotted on figure 31. Cumulative rainfall data are shown in figure 32. All weather parameters and sand transport measured at AZ C:13:0006 in 2008 are summarized in figures 33 and 34.

It is notable that rainfall measured at AZ C:13:0006 was substantially greater than at any other station in 2008 (fig. 32). The annual rainfall total was $329.2 \mathrm{~mm}$ at AZ C:13:0006 (table 2), with the greatest single event being a winter storm on January 5-7, 2008, for which the 3-day rainfall total at AZ C:13:0006 was $75.2 \mathrm{~mm}$ (fig. 32). The nearest other weather station operating during that January storm, at AZ C:13:0336 (discussed below), approximately $10 \mathrm{~km}$ downstream, recorded only half that amount of rain for those three days $(37.2 \mathrm{~mm})$ and had an annual rainfall of $234.7 \mathrm{~mm}$.

Although wind from the northwest is not uncommon around AZ C:13:0006 (fig. 31), net potential sediment transport from the east-southeast is indicated during 2008, similar to conditions measured here in 2007 (Draut and others, 2009). Net sand transport from the southeast would be consistent with the fluvial sand deposit at the downstream end of the debris fan serving as a possible source of windblown sand (fig. 30); however, sand-transport rates measured in 2008 were no higher than in 2007 and, even after the 2008 HFE, remain substantially lower than in active dune fields such as that at AZ C:13:0365, with daily flux less than $0.1 \mathrm{~g} / \mathrm{cm}$ (fig. 33).

\section{AZ C:13:0336}

The Palisades (Palisades of the Desert) area, in eastern Grand Canyon, is characterized by alluvial terraces with local aeolian coppice dunes that are vegetated by grasses and small mesquite trees. The alluvial deposits at Palisades represent multiple episodes of flood plain aggradation by Colorado River floods that predate the closure of Glen Canyon Dam in 1963 (for example, Hereford and others, 1996; Draut and oth- 
ers, 2008). Consistent with the findings of Hereford and others (1996), the aeolian dunes at Palisades were interpreted by Draut and Rubin (2008) as RFS aeolian deposits that formed by in place reworking of ancient flood sediment, rather than having been sourced from river-level sandbars within the normal dam-controlled flow range. Alluvial and aeolian deposits are incised by a major gully network (as much as 2 $\mathrm{m}$ deep and tens of $\mathrm{m}$ wide in places) that drains to the river (Hereford and others, 1993; Thompson and Potochnik, 2000; Hazel and others, 2008b). Repeated topographic surveys have shown frequent changes in gully geometry at Palisades, including aggradation in its mouth as a result of high-flow experiments in 1996 and 2004 and episodic erosion attributed to rain events (Yeatts, 1996; Hazel and others, 2008b). The sandbar nearest to AZ C:13:0336 increased in area by 35 percent and increased in volume by 154 percent as a result of the March 2008 HFE (table 4; fig. 35). Between March and October 2008, this sandbar lost 31 percent of its area and 42 percent of its volume (table 4), attributed largely to the collapse of steep cutbanks during summer daily flow fluctuations (for example, see photograph in fig. 35D).

One weather station and one set of sand traps operate at station AZ C:13:0336 U. In February 2008, one additional set of sand traps was deployed at a site referred to as $\mathrm{AZ}$ C:13:0336 $\mathrm{L}$ on a cobble bar riverward of AZ C:13:0336 U (fig. 36). The AZ C:13:0336 L study site is approximately $50 \mathrm{~m}$ upstream of where a single set of sand traps was used by Draut and Rubin (2008) to study sand transport near river level following the $2004 \mathrm{HFE}$.

Wind speed and direction measured at AZ C:13:0336 U in 2008 are plotted on figure 37. Cumulative rainfall data are shown in figure 38 . All weather parameters and sand transport measured at AZ C:13:0336 U and sand transport measured at AZ C:13:0336 L in 2008 are summarized in figures 39 and 40 with 2007 data shown for comparison.

Net potential sediment transport from the east-southeast is indicated at AZ C:13:0336 U during 2008 (fig. 36), similar to conditions measured here in previous years (Draut and Rubin, 2008; Draut and others, 2009). A vector sum of wind data from the weather station at AZ C:13:0336 U in 2008 yields a net $\mathrm{Qp}$ magnitude of $691,470 \mathrm{~m}^{3} / \mathrm{s}^{3}$ from a direction of $133^{\circ}$; using wind data only from when the sand is estimated to have been dry, a vector sum yields a net Qp magnitude of $415,870 \mathrm{~m}^{3} / \mathrm{s}^{3}$ from a direction of $137^{\circ}$ (fig. 36 ). Therefore, although the sandbar riverward (southwest) of the study sites enlarged substantially during the $2008 \mathrm{HFE}$, the dominant wind direction here would not move sand from the sandbar into the dune field (even though, on occasion, wind does blow from the southwest here; fig. 37). Sand-transport rates measured at $\mathrm{AZ} \mathrm{C:13:0336} \mathrm{U}$ in 2008 were lower than in 2007 (fig. 39) and were not significantly higher during the spring than at any other time of year, in contrast to conditions measured at this site in spring 2004, 2005, and 2007 (Draut and Rubin, 2008). During 2008, daily sand-transport rates measured at AZ C:13:0336 $\mathrm{U}$ did not exceed $1 \mathrm{~g} / \mathrm{cm}$, and transport rates on the cobble bar near river level (AZ $\mathrm{C}: 13: 0336 \mathrm{~L}$ ) were generally one-twentieth as great as those within the dune field (AZ C:13:0336 U; fig. 39).

As noted above, annual rainfall at AZ C:13:0336 (table 2, fig. 38) is substantially lower, at $234.7 \mathrm{~mm}$, than at the next-nearest station AZ C:13:0006, $10 \mathrm{~km}$ upstream. This spatial variability between river mile 60 and 65 is consistent with rainfall patterns measured in previous years (Draut and Rubin, 2005, 2006; Draut and others, 2009).

\section{AZ C:13:0321}

One set of BSNE sand traps was deployed in a moderately vegetated aeolian sand deposit near river level at AZ C:13:0321 on February 10, 2008, to measure sand-transport rates following the March high flow. At this site, large ( $>10$ $\mathrm{m}$ high), well established aeolian dunes are present inland from a fluvial sandbar; the orientation of dune slip faces indicates migration toward the northeast (inland), suggesting that this site is most likely an MFS aeolian deposit downwind of an active, modern sandbar. The sandbar and the aeolian deposit area immediately inland of the sandbar were photographed and surveyed before and after the 2008 HFE to study their response to the high flow (fig. 41).

The sandbar near AZ C:13:0321 increased substantially in area (by 129 percent) and volume (90 percent) owing to sediment deposition from the March 2008 HFE (table 4; fig. 41); reworking of sand by the HFE apparently also leveled out a small aeolian dune crest present near the HFE high-water mark before the high flow (profile 2 on fig. 42). Between March and October 2008, this sandbar lost 7 percent of its area and 17 percent of its volume (table 4). By July 2008, wind had reworked sand from the HFE sandbar to form a new aeolian dune more than $1 \mathrm{~m}$ high (figs. $41 \mathrm{D}, 42$ ). The shape and slipface orientation of the new dune face indicated that it was migrating (and moving sand) inland, toward the well established dune field consisting of larger, vegetated dunes $>10 \mathrm{~m}$ tall that are inland above the postdam high-water elevation. When surveyed in October 2008, the new dune was taller (by $1.5 \mathrm{~m}$ ) than the surface of the sandbar deposited by the HFE, and its crest was approximately $1 \mathrm{~m}$ higher than the maximum elevation reached by the HFE water (profile 2 in fig. 47). Because this site was monitored beginning in February 2008, it is not possible to compare sandtransport rates with the year before the HFE, but daily sand flux of 1-3 grams per centimeter measured here during 2008 (fig. 43) was similar to that measured near river level at an active dune field upstream (AZ C:13:0365 L). Although wind conditions were not measured directly at AZ C:13:0321, the dune migration direction indicates a dominant sand-transport direction from southwest toward northeast (sand moving inland). This is consistent with net sediment-transport directions derived from wind measurements at the nearest weather stations (at AZ C:13:0346, discussed below), which are situated $700 \mathrm{~m}$ away from AZ C:13:0321 (fig. 44). 


\section{AZ C:13:0346}

Two instrument stations operated near river mile 70: AZ C:13:0346 L and AZ C:13:0346 U in 2008. This reach of the Colorado River corridor in eastern Grand Canyon is several $\mathrm{km}$ wide, is characterized by $\mathrm{km}$ wide meander bends in the river, and is part of the geomorphic region referred to as the Furnace Flats reach by Schmidt and Graf (1987). It is not known whether sandbars in the vicinity of AZ C:13:0346 grew substantially as a result of the $2008 \mathrm{HFE}$; in general, the dune field there is bordered by riparian vegetation and not by sandbars (fig. 44). The station AZ C:13:0346 L is situated within an active dune field that has moderate vegetation coverage, well-developed dune forms, and abundant active sediment transport. Multiple failures of the Vaisala sensor at this station occurred in 2007 (Draut and others, 2009), and data was not collected at this station for the first 40 days of 2008 . The sensor was replaced on February 10, 2008, after which data were collected for the remainder of the year without interruption.

Wind speed and direction measured at AZ C:13:0346 L in 2008 are plotted on figure 45. Cumulative rainfall data are shown in figure 46; total rainfall measured in 2008, excluding the first 40 days of the year when the station was not operating, was $202.6 \mathrm{~mm}$. All weather parameters and sand transport measured at AZ C:13:0346 L in 2008 are summarized in figures 47 and 48, with 2007 data shown for comparison.

A vector sum of wind data from the weather station at AZ $\mathrm{C}: 13: 0346 \mathrm{~L}$ in 2008 yields a net $Q p$ magnitude of 748,550 $\mathrm{m}^{3} / \mathrm{s}^{3}$ from a direction of $252^{\circ}$; using wind data only from when the sand is estimated to have been dry, a vector sum yields a net $Q p$ magnitude of $374,710 \mathrm{~m}^{3} / \mathrm{s}^{3}$ from a direction of $254^{\circ}$ (fig. 44). These net potential sand-transport directions reflect a strong directional component from the west-southwest (fig. 45). Daily sand-transport rates at AZ C:13:0346 L were highest in late winter and early spring, although with no measurable spike during the high winds that occurred in April and May (fig. 47). Similar to conditions in 2007, strong winds were measured in October at this site. Unlike in 2007, for reasons unknown, those October winds did not correspond to an increase in sand-transport rates; the October high winds were not accompanied by rain, and no sand-trap malfunctions were known to have occurred then.

Station AZ C:13:0346 U is situated upstream of AZ $\mathrm{C}: 13: 0346 \mathrm{~L}$ and slightly farther inland from the river (fig. 49). The land surface in the vicinity of station AZ C:13:0346 $\mathrm{U}$ includes relatively inactive dunes on a broad, flat landscape with abundant silty material, some derived from relict fluvial deposits and some comprising distal slope-wash from local bedrock. Biologic soil crust is more abundant around AZ C:13:0346 U than around AZ C:13:0346 L. Station AZ C:13:0346 U experienced several interruptions in its operation during 2008 and did not collect data during the following intervals: January 1-7, March 20-April 4, May 14-July 29, and September 6-October 18 (year days 1-7, 80-95, 135-211, and 250-292, respectively). On October 18, both the Vaisala transmitter and Nexsens data logger were replaced; the station collected data normally thereafter. Wind speed and direction measured at AZ C:13:0346 U in 2008 are plotted on figure 50. Cumulative rainfall data are shown in figure 51; total rainfall measured in 2008, excluding the intervals when the station was not operating, was $180.4 \mathrm{~mm}$. All weather parameters and sand transport measured at AZ C:13:0346 U in 2008 are summarized in figures 52 and 53, with 2007 data shown for comparison.

A vector sum of all available wind data from $A Z$ C:13:0346 U in 2008 yields a net $Q p$ magnitude of 381,070 $\mathrm{m}^{3} / \mathrm{s}^{3}$ from a direction of $237^{\circ}$; using wind data only from when the sand is estimated to have been dry, a vector sum yields a net $Q p$ magnitude of $445,970 \mathrm{~m}^{3} / \mathrm{s}^{3}$ from a direction of $234^{\circ}$ (fig. 49). These net potential sand-transport directions reflect a consistent directional component from the west-southwest (fig. 50), although less strongly than at AZ C:13:0346 L (fig. 44).

Aeolian sediment-transport rates at AZ C:13:0346 U were, in general, approximately one-tenth of those measured at AZ C:13:0346 L (figs. 47, 52). Similar difference in sandtransport rates between these two stations occurred in 2007. The difference is likely caused partly by biologic soil crust around station AZ C:13:0346 U inhibiting entrainment and transport of sand by wind (Leys and Eldridge, 1998; Belnap, 2003; Goossens, 2004) and partly by wind velocities having been slightly higher at AZ C:13:0346 L (figs. 47, 52). Neither station showed increased sand-transport rates in spring 2008 compared to spring 2007. Similar to conditions measured at AZ C:13:0346 L, high winds occurred at AZ C:13:0346 U in October 2008 that apparently did not have much effect on sand-transport rates (fig. 52).

\section{AZ B:11:0281}

One instrument station operated near AZ B:11:0281 throughout 2008 with no interruptions. This station is situated on the upstream side of a small debris fan that formed at the mouth of an ephemeral tributary drainage (fig. 54). The land surface at this site consists of moderately active aeolian dunes with moderate vegetation cover and biologic soil crust. Inland from the river on its south side, fine-grained sedimentary deposits occur near AZ B:11:0281 that are thought to have settled out of suspension as the river flow ponded behind a large landslide deposit that temporarily dammed the river 3 $\mathrm{km}$ downstream around $20 \mathrm{ka}$ (Huntoon, 2003; R.H. Webb, written comm., 2008). Sandbars $400 \mathrm{~m}$ upstream and $200 \mathrm{~m}$ downstream of AZ B:11:0281 received new fluvial sand as a result of the $2008 \mathrm{HFE}$, according to qualitative observations by river runners who utilized the new sandbars as camping beaches after the high flow, but those sand deposits were neither photographed nor surveyed by science parties.

Wind speed and direction measured at AZ B:11:0281 in 2008 are plotted on figure 55. Cumulative rainfall data are shown in figure 56; total rainfall measured in 2008 was 298.8 $\mathrm{mm}$. All weather parameters and sand transport measured at AZ B:11:0281 in 2008 are summarized in figures 57 and 58, with 2007 data shown for comparison. 
A vector sum of all wind data from AZ B:11:0281 in 2008 yields a net $Q p$ magnitude of $52,521 \mathrm{~m}^{3} / \mathrm{s}^{3}$ from a direction of $99^{\circ}$; using wind data only from when the sand is estimated to have been dry, a vector sum yields a net $Q p$ magnitude of $13,756 \mathrm{~m}^{3} / \mathrm{s}^{3}$ from a direction of $97^{\circ}$ (fig. 54). These net potential sand-transport directions reflect a consistent directional component from the east-southeast (fig. 55). Daily sand-transport rates were substantially lower at AZ B:11:0281 than at Palisades (AZ C:13:0336 U, where the terrain is similar), which we attribute primarily to consistently higher wind speeds at Palisades (figs. 39, 57). Sand transport around AZ B:11:0281 did not increase during spring 2008, even though wind speed was generally higher then than in other seasons, and daily sand-transport rates remained below $0.1 \mathrm{~g} /$ $\mathrm{cm}$ throughout the year, less than a third the rates that were measured during spring 2007 (fig. 57). Sand transport also did not increase in response to a high-wind event in October 2008, when rainfall and relative-humidity measurements indicate that sand should have been dry enough to be mobilized by wind (figs. 57, 58). This may have been caused by vegetation upwind (east) of the sand traps limiting sand entrainment, a possibility that will be evaluated further during field work in 2009.

\section{AZ A:15:0033}

One instrument station operated near archaeological site AZ A:15:0033 in 2008, with no interruptions. The study site includes an aeolian dune field near river level that is covered by moderately dense vegetation (fig. 59). The vegetation has grown on the dune field and on a large river-level sandbar just downstream from the dune field since the 1960s and now covers much of what was previously open sand area (Draut and Rubin, 2008). Immediately upstream of the weather station, an aeolian dune field shows evidence of deflation, some biologic soil crust, and gully incision. It is not known whether riparian sandbars near this study site increased in area or volume as a result of the March 2008 HFE, as no topographic surveys were conducted in this area; anecdotal evidence from people who observed this area shortly after the high flow indicates that the HFE did not form substantial new sand deposits near AZ A:15:0033.

Wind speed and direction measured at AZ A:15:0033 in 2008 are plotted on figure 60. Cumulative rainfall data are shown in figure 61; total rainfall measured in 2008 was 264.6 $\mathrm{mm}$. All weather parameters and sand transport measured at A:15:0033 in 2008 are summarized in figures 62 and 63, with 2007 data shown for comparison.

Wind conditions measured at station AZ A:15:0033 in 2004, 2005, and 2007 were complex; although upstream and downstream winds nearly balanced each other, vector components from the northeast yield net potential sand flux toward the river (Draut and Rubin, 2006, 2008). A vector sum of all wind data from AZ A:15:0033 in 2008 yields a net $Q p$ magnitude of $5,856 \mathrm{~m}^{3} / \mathrm{s}^{3}$ from a direction of $276^{\circ}$; using wind data only from when the sand is estimated to have been dry, a vector sum yields a net $Q p$ magnitude of $4,837 \mathrm{~m}^{3} / \mathrm{s}^{3}$ from a direction of $281^{\circ}$ (fig. 60). As in past years, these net potential sand-transport directions reflect a balance between upstream and downstream winds, with the "winning" net transport vector weakly from the west (figs. 59, 60).

Daily sand-transport rates at AZ A:15:0033 were the lowest measured at any study site in 2007 and 2008 (fig. 62), always below $0.01 \mathrm{~g} / \mathrm{cm}$ in 2008 . This is attributed to the density of vegetation cover near the instrument station (Bressolier and Thomas, 1977; Buckley, 1987). Sand transport at this site was no higher in the spring than at other times of year in either 2007 or 2008.

\section{AZ G:03:0072}

During 2008, one complete instrument station operated at AZ G:03:0072 (station AZ G:03:0072 U; table 1) along with one additional set of sand traps (station AZ G:03:0072 L; locations are shown on fig. 64). The study sites are on sedimentary deposits that cover the downstream part of a debris fan. Station AZ G:03:0072 $\mathrm{U}$ is in an active aeolian dune field that has sparse vegetation and patches of biologic soil crust. The sand traps at AZ G:03:0072 L are at lower elevation and closer to the river than AZ G:03:0072 $\mathrm{U}$, in an area with some biologic soil crust; moderate to thick vegetation is present between $\mathrm{AZ}$ G:03:0072 L and the river (fig. 64). All equipment near AZ G:03:0072 operated throughout 2008 with no interruptions. Members of a river trip in spring 2008 reported observing a minor new sand deposit in the eddy immediately downstream of AZ G:03:0072 after the HFE, but this deposit was not photographed or surveyed.

Wind speed and direction measured at AZ G:03:0072 U in 2008 are plotted on figure 65. Cumulative rainfall data are shown in figure 66; total rainfall measured in 2008 was 248.9 $\mathrm{mm}$. All weather parameters and sand transport measured at G:03:0072 $\mathrm{U}$ in 2008, and sand transport measured at AZ G:03:0072 L, are summarized in figures 67 and 68, with 2007 data shown for comparison.

A vector sum of all available wind data from AZ G:03:0072 U in 2008 yields a net $Q p$ magnitude of $65,861 \mathrm{~m}^{3} /$ $\mathrm{s}^{3}$ from a direction of $187^{\circ}$; using wind data only from when the sand is estimated to have been dry, a vector sum yields a net $Q p$ magnitude of $52,188 \mathrm{~m}^{3} / \mathrm{s}^{3}$ from a direction of $187^{\circ}$ (fig. 64). This net flux direction toward upstream reflects a balance between upstream and downstream winds, with a minor component from approximately $290^{\circ}$, which we attribute to local topographic effects-wind moving down the side canyon toward the river (fig. 65).

Daily sand-transport rates measured at AZ G:03:0072 L and AZ G:03:0072 U were similar, although slightly higher at AZ G:03:0072 U, commonly on the order of $0.1 \mathrm{~g} / \mathrm{cm}$ (fig. 67). Daily sand-transport rates at AZ G:03:0072 L were below $0.05 \mathrm{~g} / \mathrm{cm}$ throughout 2008 (fig. 67). Higher sand-transport rates at AZ G:03:0072 $\mathrm{U}$ are attributed to the higher elevation above river level (where wind speeds are commonly higher than near the river) and reduced effects of vegetation in the 
active dune area there. Aeolian sediment-transport rates at $\mathrm{AZ}$ G:03:0072 U were only slightly higher during the spring of 2008 than in other seasons that year and were no higher than in spring 2007 (fig. 67).

\section{Discussion}

According to the National Climatic Data Center (NCDC), drought conditions that were prevalent in the Southwestern United States in 2007 abated somewhat during 2008; Arizona experienced near-normal precipitation for the year as a whole, with 2008 being the 60th wettest year of 114 in which precipitation has been monitored (NCDC; http://www.ncdc.noaa. gov/). The 2007-08 winter began with above-normal precipitation in the Southwest, counteracted by below-normal precipitation in subsequent months. Overall temperatures in Arizona and the Southwest generally were above normal (above the 1896-2008 average), particularly in summer and fall; detailed climatic summaries for the United States in 2008 are available from the NCDC (http://www.ncdc.noaa.gov/oa/climate/ research/2008/ann/us-summary.html; last accessed May 26, 2009). El Niño/Southern Oscillation (ENSO) conditions began 2008 in a La Niña (cool) mode, which lasted from September 2007 to June 2008. By the end of 2008, the ENSO cycle was in a neutral phase (http://www.ncdc.noaa.gov/oa/climate/ research/enso/; last accessed May 26, 2009).

Comparing 2007 and 2008 weather in Grand Canyon is complicated by data gaps in our 2007 record (Draut and others, 2009), but the continuity of the 2008 records reveal some clear patterns. Similar to conditions measured in previous years in the Colorado River corridor through Grand Canyon, rainfall in 2008 was highly spatially variable among the study sites. As in past years (Draut and Rubin, 2008; Draut and others, 2009), the greatest rainfall amounts were measured in eastern Grand Canyon near river mile 60, where event-based and annual total rainfall are commonly twice as great as a short distance downstream near river mile 65 (for example, figs. 32, 38). This spatial difference occurs both during individual storms, such as the one that occurred from January 5-7, 2008 (table 2), and also over the year as a whole, and is attributed to local topographic effects of the Walhalla Plateau, which rises above the western rim ("North Rim") of the canyon near river miles 57-64.

In two dune fields that experience active aeolian sand transport, near river miles 60 and 70, we observed that the inability of the Vaisala sensors to distinguish between the impact of raindrops and windblown sediment particles likely causes rainfall readings to be erroneously high at two of the study sites especially during spring, when wind velocities are commonly highest (AZ C:13:0365 U and AZ C:13:0346 L).

At each site, the season with the most intense rainfall accumulation occurred between year days 180 and 270 (late June to late September), when summer monsoon storms bring intense, spatially concentrated rain events. During the mon- soon season, although intense rain events occur, daily fluctuations in barometric pressure are low-commonly less than 10 mbar. In contrast, weather patterns at other times of year are accompanied by greater diurnal barometric-pressure variations (20 mbar or more), as is apparent in figures 9, 14, 22, 27, 34, $40,48,53,58,63$, and 68 .

\section{Effects of the March 2008 High-Flow Experiment}

Observations of sand-transport rates in 2007 and 2008, and, at some sites, of changing sandbar area and volume, can be used to evaluate the effectiveness of the March 2008 HFE to enhance windblown transport of sand inland. Effects of the 2008 HFE on aeolian sand transport are summarized here; these, and associated implications for management, will be discussed in detail in a forthcoming USGS publication.

In general, investigations of the HFEs that occurred in 2004 and 2008 have shown that, under sufficiently sandenriched conditions in the mainstem river channel, HFEs can create new sandbars and enlarge existing ones, at least on time scales of months; this was observed at the five sites studied for this project where sandbar area and volume were quantified (table 4; figs. 4, 17, 29, 41, 42). Unlike sandbars formed by the November 2004 HFE, from which sand rapidly eroded owing to high fluctuating flows in January to March 2005 (Draut and Rubin, 2008), the 2008 HFE sandbars were present during spring months, the season when windblown sand transport is generally greatest in Grand Canyon. Topographic surveys showed that, after having gained sand volume as a result of the March 2008 HFE, sandbars commonly lost sand volume between March and October 2008 (table 4). This is largely attributed to cutbank erosion resulting from summer daily flow fluctuations, which were generally $340-509 \mathrm{~m}^{3} / \mathrm{s}$ $\left(12,000-18,000 \mathrm{ft}^{3} / \mathrm{s}\right)$, although some volume loss could also have occurred by wind deflation; sandbar profile surveys show evidence of both processes (figs. 4, 17, 29, 42). That some sandbars gained area (while losing sand volume) between March and October 2008, whereas others lost area (table 4), likely reflects the collapse of cutbanks.

At two of nine study sites (AZ C:13:0321 and AZ C:13:0365), spring and summer winds reworked the 2008 HFE sandbars to form new aeolian dunes (figs. 16, 41D). The shape and orientation of the dunes in both cases indicated sand movement inland toward larger, well-established dune fields.

At the other seven study sites, HFE deposits did not form sizeable aeolian dunes, there was no clear evidence for HFEdeposited sand moving inland by wind, and sand-transport rates after the 2008 HFE were similar to or lower than in previous years. At two sites, AZ C:13:0336 and AZ A:15:0033, this result was expected because the associated aeolian dunes are RFS sedimentary deposits, the sand sources of which occur at too high an elevation to have been replenished by the March 2008 HFE.

Three of the remaining five study sites (AZ C:05:0031, AZ B:11:0281, and AZ G:03:0072) contain predominantly MFS aeolian dunes, downwind of fluvial sandbars capable of 
being enlarged by HFEs, but had wind conditions in spring 2008 that were not effective at moving sand inland. At AZ C:05:0031, increased aeolian sand transport from the sandbar to the dune field was documented after the November 2004 HFE, but no similar response occurred after the 2008 HFE. In spring 2008, the wind instead blew predominantly upstream, parallel to the river at this site (table 3). Wind conditions, therefore, were not conducive to moving new HFE sand inland toward the dunes at AZ C:05:0031. At AZ B:11:0281 and AZ G:03:0072, although the prevailing wind directions from March to June 2008 (year days 60-180) were oriented inland toward dune fields (table 3), spring sand transport was no higher in 2008 than in 2007. This may have been because wind was not substantially stronger during spring 2008 than at other times of year (figs. 57, 67) or because upwind obstacles limit sand transport at the sand-trap sites, a possibility that will be evaluated during field work in 2009. The degree of sandbar growth from the HFE is unknown at those two sites because they were not surveyed.

The final two study sites, AZ C:13:0006 and AZ C:13:0346, showed no increase in aeolian sand transport after the 2008 HFE. This may be because sandbars near those sites did not enlarge much or because (although in the past enough fluvial sand moved inland to form dunes) the dune field at each site is now separated from river-level sandbars by vegetation and/or topographic barriers.

At AZ C:13:0006, the typical wind direction is consistent with movement of sand inland toward an MFS aeolian dune field; however, sand-transport rates in the dune field were no higher in 2008 than in 2007 (fig. 33). Lack of increased sand flux in the AZ C:13:0006 dune field may be because not much new sand was available on the source sandbar (having lost area; table 4) and/or because sand must cross a side canyon, $\sim 5 \mathrm{~m}$ wide, to move from the sandbar toward the dune field and instrument station (fig. 30). Although this topographic influence (the side canyon) is not new, and windblown sand must have crossed it in the past to form the dune field, it is possible that a much larger sandbar would be required upwind for sand transport across the side canyon to increase measurably. Considering observations by Collins and others (2009) that substantial quantities $\left(>25 \mathrm{~m}^{3}\right)$ of sand were deposited by wind at the archaeological site AZ C:13:0006 between 2006 and 2007, it is possible that the low sand-transport rates measured at the weather station in 2007 and 2008 (situated approximately $20 \mathrm{~m}$ laterally away from and $5 \mathrm{~m}$ vertically below the archaeological site) do not accurately reflect aeolian processes affecting the cultural site. However, to avoid disturbing the archaeological site, we cannot deploy sand traps to measure sand transport directly in the area where Collins and others (2009) used remote-sensing lidar equipment to record aeolian sand deposition at AZ C:13:0006. Therefore, links among HFE sand deposition, aeolian sand transport, and inflation/deflation at the archaeological site AZ C:13:0006 may not be resolved accurately using the data collected by this study.

At Site AZ C:13:0346, although the dominant wind direction was oriented such that it could have moved sand inland and upslope toward large dunes (figs. 44, 49), neither station there measured any increase in aeolian sand transport in 2008 relative to 2007 (figs. 47, 52). At this site, any new HFE sand deposited on sandbars upwind of this dune field is separated from the dunes by a thick band of riparian vegetation parallel to the river. It is likely that any new fluvial sand would not readily move toward the dunes near AZ C:13:0346 unless the vegetation were removed. This suggests that although these dunes could potentially receive sand from HFE deposits if vegetation were absent, this dune field is presently behaving as a relict (RFS) feature that receives little or no sand from modern fluvial sandbars.

\section{Conclusions}

Analysis of weather patterns in the Colorado River corridor through Grand Canyon, Ariz., was facilitated in 2008 by improved equipment performance compared with 2007, owing to software and hardware modifications made throughout 2007. Data collected in 2008 clearly reveal eventand seasonal-scale variations in rainfall, wind, temperature, humidity, and barometric pressure. Broad seasonal changes in aeolian sand flux are also apparent at most study sites, although the resolution of sand-transport variations depends upon the intervals of manual sample collection. The quantitative methods and data discussed here form a basis for monitoring ecosystem processes that affect archaeologicalsite stability. Combined with work by other researchers to evaluate landscape evolution at nearby archaeological sites, these data can be used to document the relationship between physical processes, including weather and aeolian sand transport, and the stability of archaeological sites.

The continuation of monitoring that began in 2007, and installation of equipment at several new sites in early 2008 , allowed evaluation of the effects of the March 2008 HFE on aeolian sand transport. At two of the nine study sites, spring and summer winds reworked HFE sandbars to form new aeolian dunes, which moved sand inland toward larger, well established dune fields. At the other seven study sites, new aeolian dunes were not observed, and sand-transport rates after the 2008 HFE were similar to or lower than in previous years. At several sites, dominant wind directions in spring 2008 were oriented such that little HFE sand would have moved inland; at other sites, lack of increased sand flux is attributable to lack of sandbar enlargement near the study sites or inhibition of sand movement by vegetation or local topography.

\section{Acknowledgments}

The Bureau of Reclamation provided financial support for this research; the funding is derived from power revenues that are provided to the USGS Grand Canyon Monitoring and 
Research Center for science activities undertaken on behalf of the Glen Canyon Dam Adaptive Management Program. C. Anderson, C. Fritzinger, C. Nelson, and Grand Canyon Youth river trips assisted with field data collection. The two anonymous reviewers who commented on an earlier draft of this report are thanked for constructive comments.

\section{References Cited}

Bagnold, R.A., 1941, The physics of blown sand and desert dunes (4th ed.): London, Chapman and Hall, 265 p.

Belnap, J., 2003, Biological soil crusts and wind erosion, in Belnap, J., and Lange, O.L., eds., Biological soil crustsstructure, function, and management: Berlin, Springer-Verlag, Ecological Studies series, v. 150, p. 339-347.

Bressolier, C., and Thomas, Y.-F., 1977, Studies on wind and plant interactions on French Atlantic coastal dunes: Journal of Sedimentary Petrology, v. 47, p. 331-338.

Buckley, R., 1987, The effect of sparse vegetation on the transport of dune sand by wind: Nature, v. 325, p. 426-428.

Collins, B.D., and Kayen, R., 2006, Applicability of terrestrial LIDAR scanning for scientific studies in Grand Canyon National Park, Arizona: U.S. Geological Survey Open-File Report 2006-1198, 32 p. [http://pubs.usgs.gov/ of/2006/1198/].

Collins, B.D., Brown, K.M., and Fairley, H.C., 2008, Evaluation of terrestrial LIDAR for monitoring geomorphic change at archeological sites in Grand Canyon National Park, Arizona: U.S. Geological Survey Open-File Report 2008-1384, 60 p. [http://pubs.usgs.gov/of/2008/1384/].

Collins, B.D., Minasian, D., and Kayen, R., 2009, Topographic change detection at select archeological sites in Grand Canyon National Park, Arizona, 2006-2007: U.S. Geological Survey Scientific Investigations Report 2009-5116, 68 p. [http://pubs.usgs.gov/sir/2009/5116/].

Draut, A.E., and Rubin, D.M., 2005, Measurements of wind, aeolian sand transport, and precipitation in the Colorado River corridor, Grand Canyon, Arizona-November 2003 to December 2004: U.S. Geological Survey Open-File Report 2005-1309, 70 p. [http://pubs.usgs.gov/of/2005/1309/].

Draut, A.E., and Rubin, D.M., 2006, Measurements of wind, aeolian sand transport, and precipitation in the Colorado River corridor, Grand Canyon, Arizona-January 2005 to January 2006: U.S. Geological Survey Open-File Report 2006-1188, 88 p. [http://pubs.usgs.gov/of/2006/1188/].
Draut, A.E., and Rubin, D.M., 2008, The role of eolian sediment in the preservation of archeologic sites along the Colorado River corridor in Grand Canyon National Park, Arizona: U.S. Geological Survey Professional Paper 1756 [http://pubs.usgs.gov/pp/1756/].

Draut, A.E., Rubin, D.M., Dierker, J.L., Fairley, H.C., Griffiths, R.E., Hazel, J.E., Jr., Hunter, R.E., Kohl, K., Leap, L.M., Nials, F.L., Topping, D.J., and Yeatts, M., 2008, Application of sedimentary-structure interpretation to geoarchaeological investigations in the Colorado River corridor, Grand Canyon, Arizona: Geomorphology, v. 101, p. 497-509.

Draut, A.E., Andrews, T., Fairley, H.C., and Brown, C.R., 2009, 2007 weather and aeolian sand-transport data from the Colorado River corridor, Grand Canyon, Arizona: U.S. Geological Survey Open-File Report 2009-1098, 110 p. [http://pubs.usgs.gov/of/2009/1098/].

Fairley, H.C., 2005, Cultural resources in the Colorado River corridor, in Gloss, S.P., Lovich, J.E., and Melis, T.S., eds., The state of the Colorado River ecosystem in Grand Canyon: U.S. Geological Survey Circular 1282, p. 177-192.

Fairley, H.C., and Sondossi, H., 2008, Applying an ecosystem framework to evaluate archaeological site condition along the Colorado River in Grand Canyon National Park, Arizona: Poster presented at Coming Together-Coordination of Science and Restoration Activities for the Colorado River Ecosystem Conference, November 19, 2008, Tempe, Ariz.

Fryrear, D.W., 1986, A field dust sampler: Journal of Soil and Water Conservation, v. 41, p. 117-119.

Goossens, D., Offer, Z., and London, G., 2000, Wind tunnel and field calibration of five aeolian sand traps: Geomorphology, v. 35, p. 233-252.

Goossens, D., 2004, Effect of soil crusting on the emission and transport of wind-eroded sediment-field measurements on loamy sandy soil: Geomorphology, v. 58, p. 145-160.

Hazel, J.E., Kaplinski, M., Parnell, R.A., Kohl, K., and Schmidt, J.C., 2008a, Monitoring fine-grained sediment in the Colorado River ecosystem, Arizona-control network and conventional survey techniques: U.S. Geological Survey Open-File Report 2008-1276, 15 p. [http://pubs.usgs.gov/ of/2008/1276/].

Hazel, J.E., Jr., Kaplinski, M., Parnell, R.A., and Fairley, H.C., 2008b, Aggradation and degradation of the Palisades gully network, 1996 to 2005, with emphasis on the November 2004 high-flow experiment, Grand Canyon National Park, Arizona: U.S. Geological Survey Open-File Report 20081264, 14 p. [http://pubs.usgs.gov/of/2008/1264/]. 
Hereford, R., Fairley, H.C., Thompson, K.S., and Balsom, J.R., 1993, Surficial geology, geomorphology, and erosion of archeologic sites along the Colorado River, eastern Grand Canyon, Grand Canyon National Park, Arizona: U.S. Geological Survey Open-File Report 93-517, 46 p.

Hereford, R., Thompson, K.S., Burke, K.J., and Fairley, H.C., 1996, Tributary debris fans and the late Holocene alluvial chronology of the Colorado River, eastern Grand Canyon, Arizona: Geological Society of America Bulletin, v. 108, p. 3-19.

Huntoon, P., 2003, Post-Precambrian tectonism in the Grand Canyon region, in Beus, S.S. and Morales, M., eds., Grand Canyon geology (second edition): New York, Oxford University Press, p. 222-259.

Kawamura, R., 1951, Study of sand movement by wind: University of Tokyo, Institute of Science and Technology Report, v. 5 no. 3-4, p. 95-112 [in Japanese].

Lettau, K., and Lettau, H.H., 1977, Experimental and micrometeorological field studies of dune migration, in Lettau, H.H., and Lettau, K., eds., Exploring the world's driest climates: Madison, University of Wisconsin, Institute of Environmental Science Report 101, p. 110-147.

Leys, J.F., and Eldridge, D.J., 1998, Influence of cryptogamic crust disturbance to wind erosion on sand and loam rangeland soils: Earth Surface Processes and Landforms, v. 23, p. 963-974.

Magirl, C.S., Breedlove, M.J., Webb, R.H., and Griffiths, P.G., 2008, Modeling water-surface elevations and virtual shorelines for the Colorado River in Grand Canyon, Arizona: U.S. Geological Survey Scientific Investigations Report 2008-5075, 40 p. [http://pubs.usgs.gov/sir/2008/5075/].

Neal, L.A., Gilpin, D., Jonas, L., and Ballagh, J.H., 2000, Cultural resources data synthesis within the Colorado River corridor, Grand Canyon National Park and Glen Canyon National Recreation Area, Arizona: SWCA Environmental Consultants, Cultural Resources Report 98-85.

Nickling, W.G., and McKenna Neuman, C., 1997, Wind tunnel evaluation of a wedge-shaped aeolian sediment trap: Geomorphology, v. 18, p. 333-345.

O'Brien, G., and Pederson, J., 2008, Gully erosion processes and parameters and six cultural sites along the Colorado River in Grand Canyon National Park, Arizona: Draft report, cooperative agreement 04HQAG0122 and subagreement 04122HS010, Utah State University and U.S. Geological Survey, Grand Canyon Monitoring and Research Center, $126 \mathrm{p}$.
Saunders, S., Montgomery, C., Easley, T., and Spencer, T., 2008, Hotter and drier- the west's changing climate: New York, Rocky Mountain Climate Organization and Natural Resources Defense Council, 54 p.

Schmidt, J.C., and Graf, J.B., 1987, Aggradation and degradation of alluvial sand deposits, 1965 to 1986, Colorado River, Grand Canyon National Park, Arizona: U.S. Geological Survey Open-File Report 87-555, 120 p.

Stout, J.E., and Fryrear, D.W., 1989, Performance of a windblown-particle sampler: American Society of Agricultural Engineers Transactions, v. 32, p. 2041-2045.

Thompson, K.S., and Potochnik, A.R., 2000, Development of a geomorphic model to predict erosion of pre-dam Colorado River terraces containing archaeological resources: SWCA Environmental Consultants, Cultural Resources Report 99-257.

Topping, D.J., Rubin, D.M., Schmidt, J.C., Hazel, J.E. Jr., Wright, S.A., Kaplinski, M., Draut, A.E., and Breedlove, M.J., 2006, Comparison of sediment-transport and barresponse results from the 1996 and 2004 controlled-flood experiments on the Colorado River in Grand Canyon: Proceedings of the 8th Federal Interagency Sediment Conference, Reno, Nevada, April 2006, ISBN 0-9779007-1-1.

Webb, R.H., Schmidt, J.C., Marzolf, G.R., and Valdez, R.A., eds., 1999, The controlled flood in Grand Canyon: Washington, D.C., American Geophysical Union Geophysical Monograph 110, 367 p.

Yeatts, M., 1996, High elevation sand deposition and retention from the 1996 spike flow-An assessment for cultural resources stabilization, in Balsom, J.R., and Larralde, S., eds., Mitigation and monitoring of cultural resources in response to the experimental habitat building flow in Glen and Grand Canyons, Spring 1996: Flagstaff, Ariz., Report to Bureau of Reclamation, and Grand Canyon Monitoring and Research Center, p. 124-158.

Zobeck, T.M., Sterk, G., Funk, R., Rajot, J.L., Stout, J.E., and Van Pelt, R.S., 2003, Measurement and data analysis methods for field-scale wind erosion studies and model validation: Earth Surface Processes and Landforms, v. 28, p. 1163-1188. 


\section{Figures}

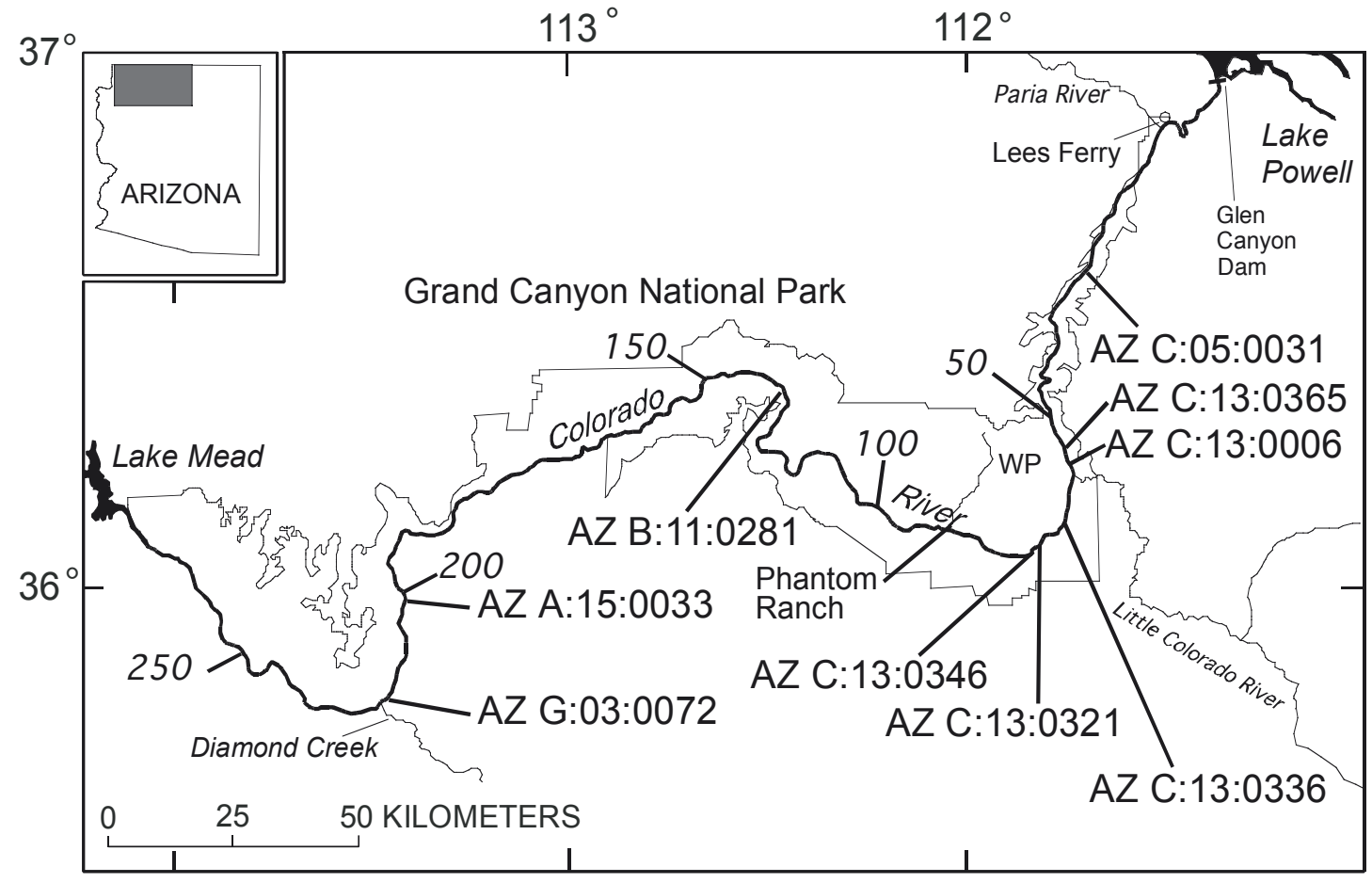

Figure 1. Colorado River corridor through Grand Canyon, Ariz., showing approximate locations of study sites. River reach between Lees Ferry and the Little Colorado River is known as Marble Canyon. WP indicates the location of the Walhalla Plateau, a promontory on the north rim of the canyon. Numbers in italics indicate river miles downstream of Lees Ferry. 


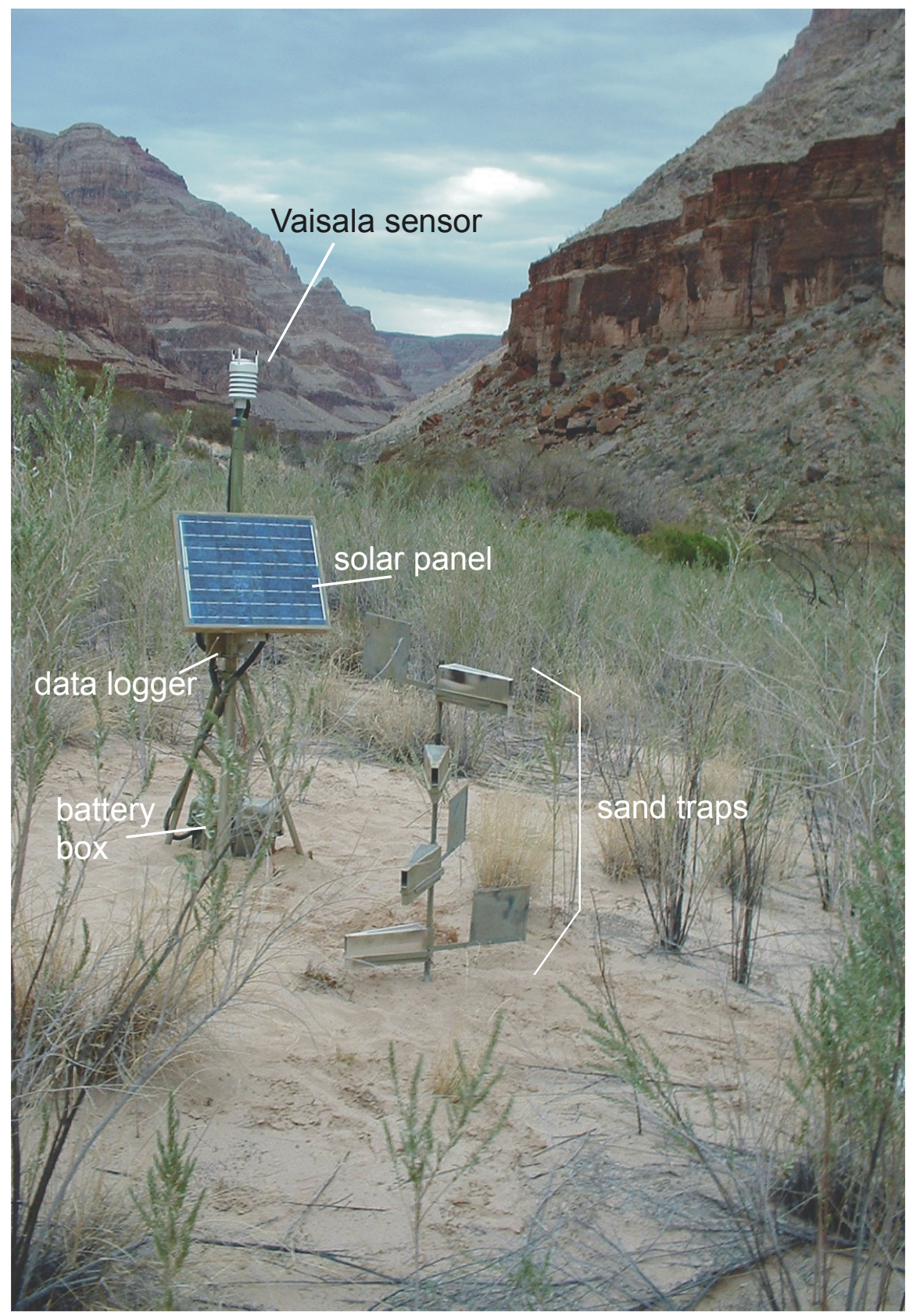

Figure 2. Photograph of instrument station near AZ A:15:0033. The sensor, data logger, and solar panel are mounted on a tripod (in this photograph, the data logger is behind the solar panel), and the system is powered by a battery housed in a box on the ground. The pole with four sand traps on it is approximately $3 \mathrm{~m}$ away from the tripod. (USGS photograph by Amy Draut.) 

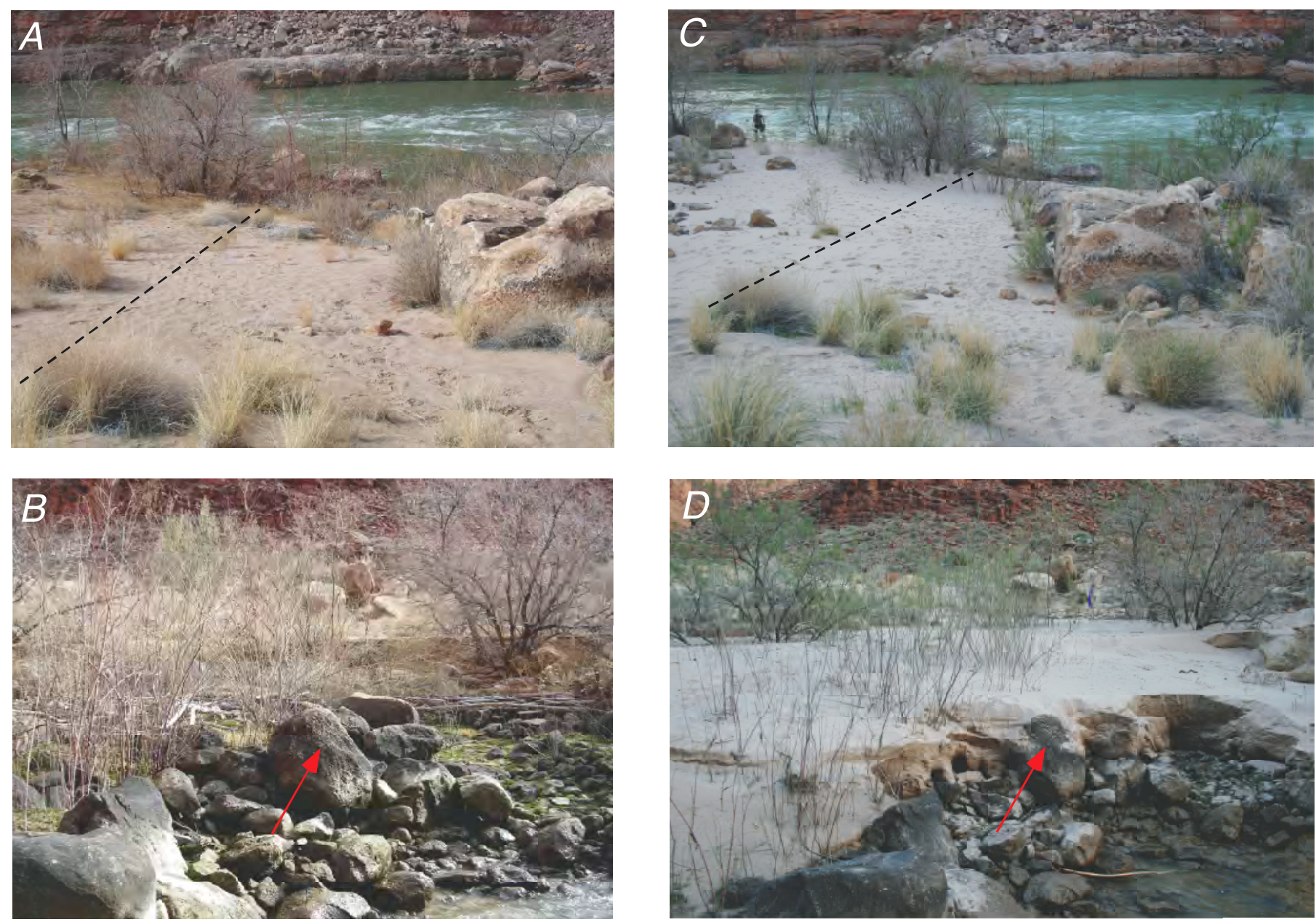

Figure 3. Photographs of the sandbar near AZ C:05:0031 before and after the 2008 high-flow experiment (HFE). $A$ and $B$ were taken on February 4, 2008 (USGS photographs by Amy Draut.); $C$ and $D$ were taken on March 29, 2008 (Northern Arizona University photographs by Joe Hazel). The red arrow on $B$ and $D$ points to the same rock in both photographs. The area shown in $A$ and $C$ includes the shoreperpendicular profile 2 plotted in figure 4 (dashed lines). 

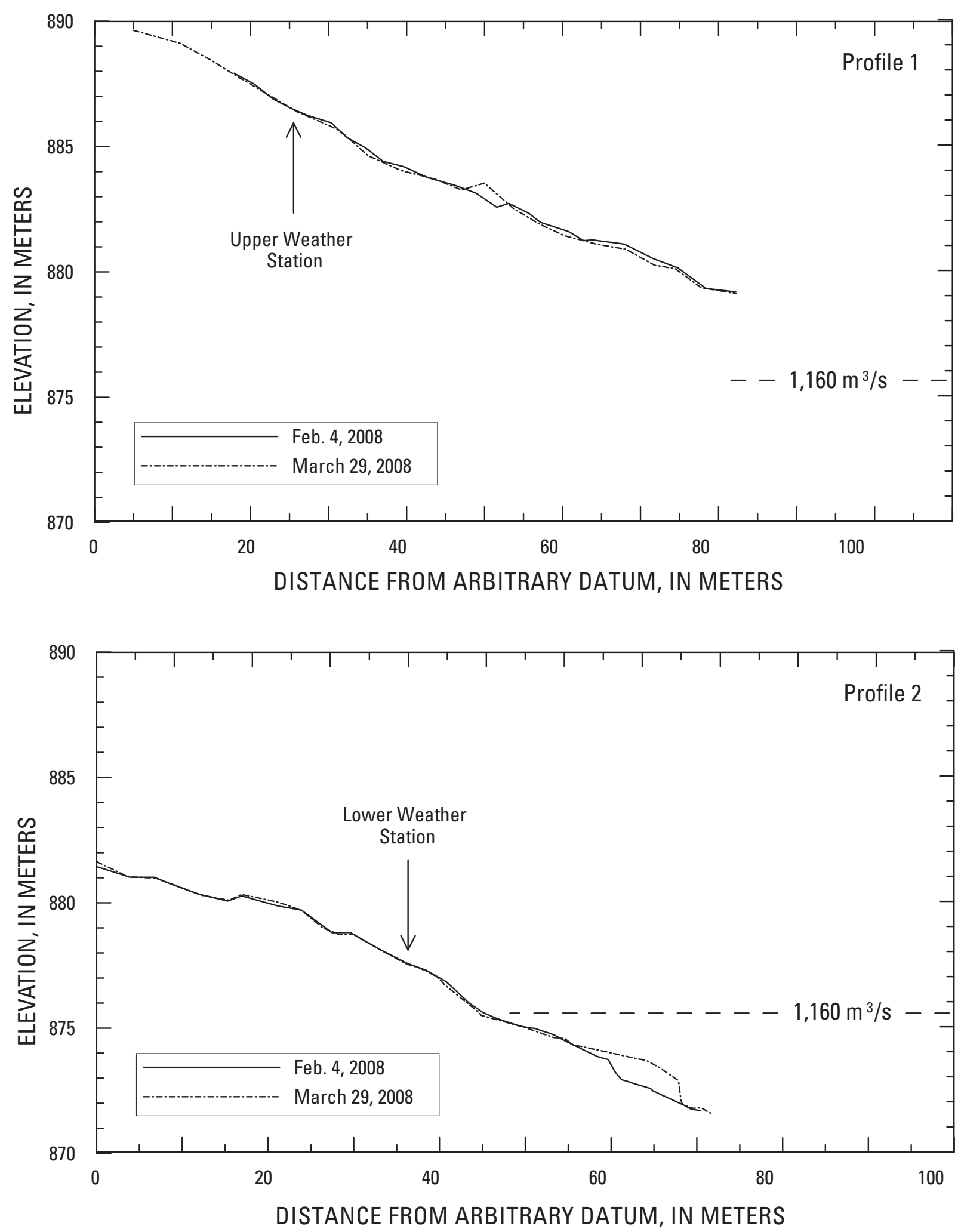

Figure 4. Surveyed profiles of the sandbar near AZ C:05:0031, in Grand Canyon, Ariz., before and after the 2008 high-flow experiment (HFE). Profiles trend east-southeast, approximately perpendicular to the channel margin. The elevation of the HFE peak stage is indicated $\left(1,160 \mathrm{~m}^{3} / \mathrm{s}\right)$. 


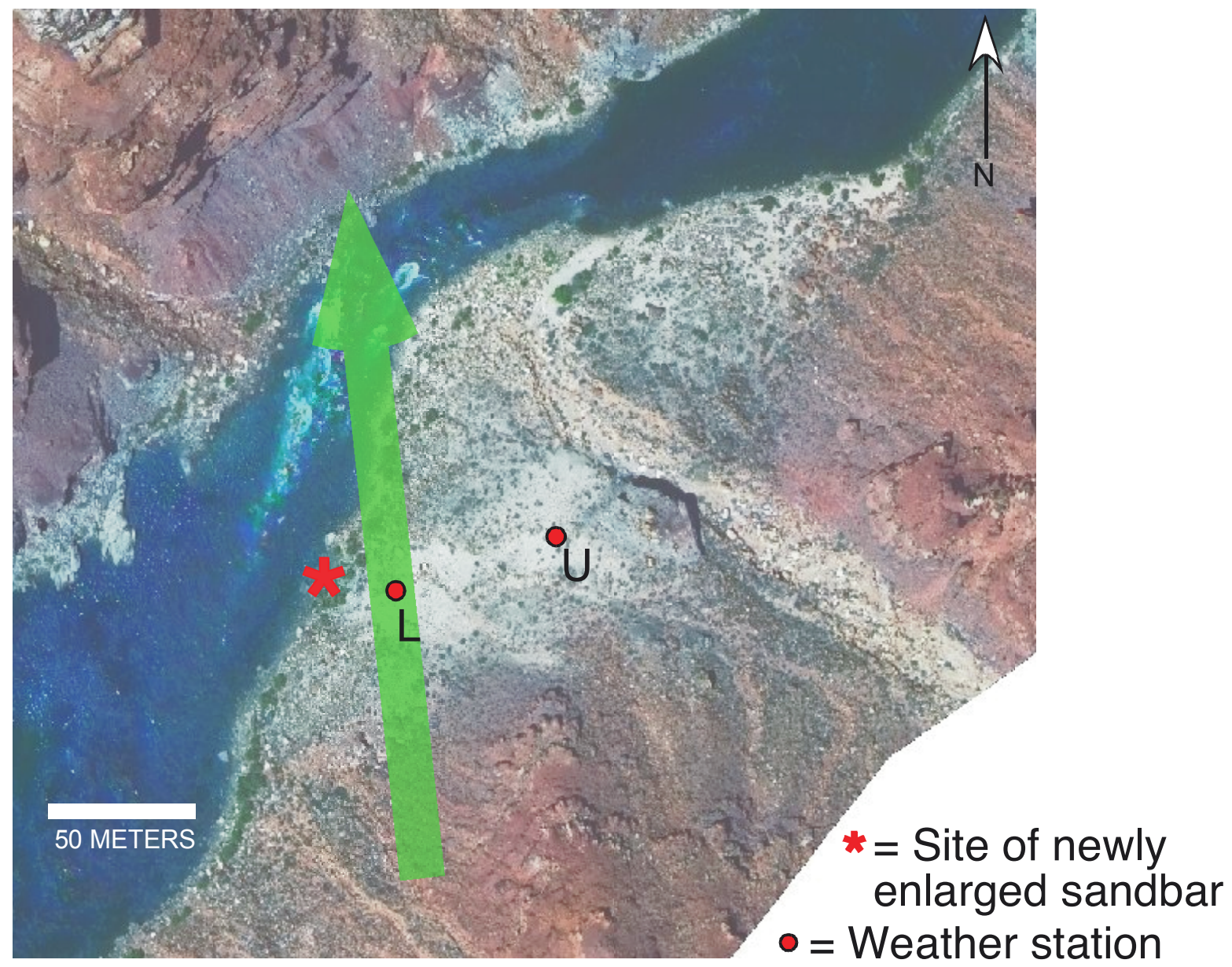

Figure 5. Aerial photograph of the area around AZ C:05:0031, in Grand Canyon, Ariz., with arrow indicating net direction of potential aeolian sediment transport measured at AZ C:05:0031 L in 2008. A vector sum of the $Q p$ proxy variable (equation 1), calculated using all available wind data from AZ C:05:0031 L in 2008, indicates net sediment transport from 174 degrees. (USGS photograph.) 


\section{4-MINUTE AVERAGE WIND SPEED, IN METERS PER SECOND AND WIND DIRECTION, IN DEGREES}

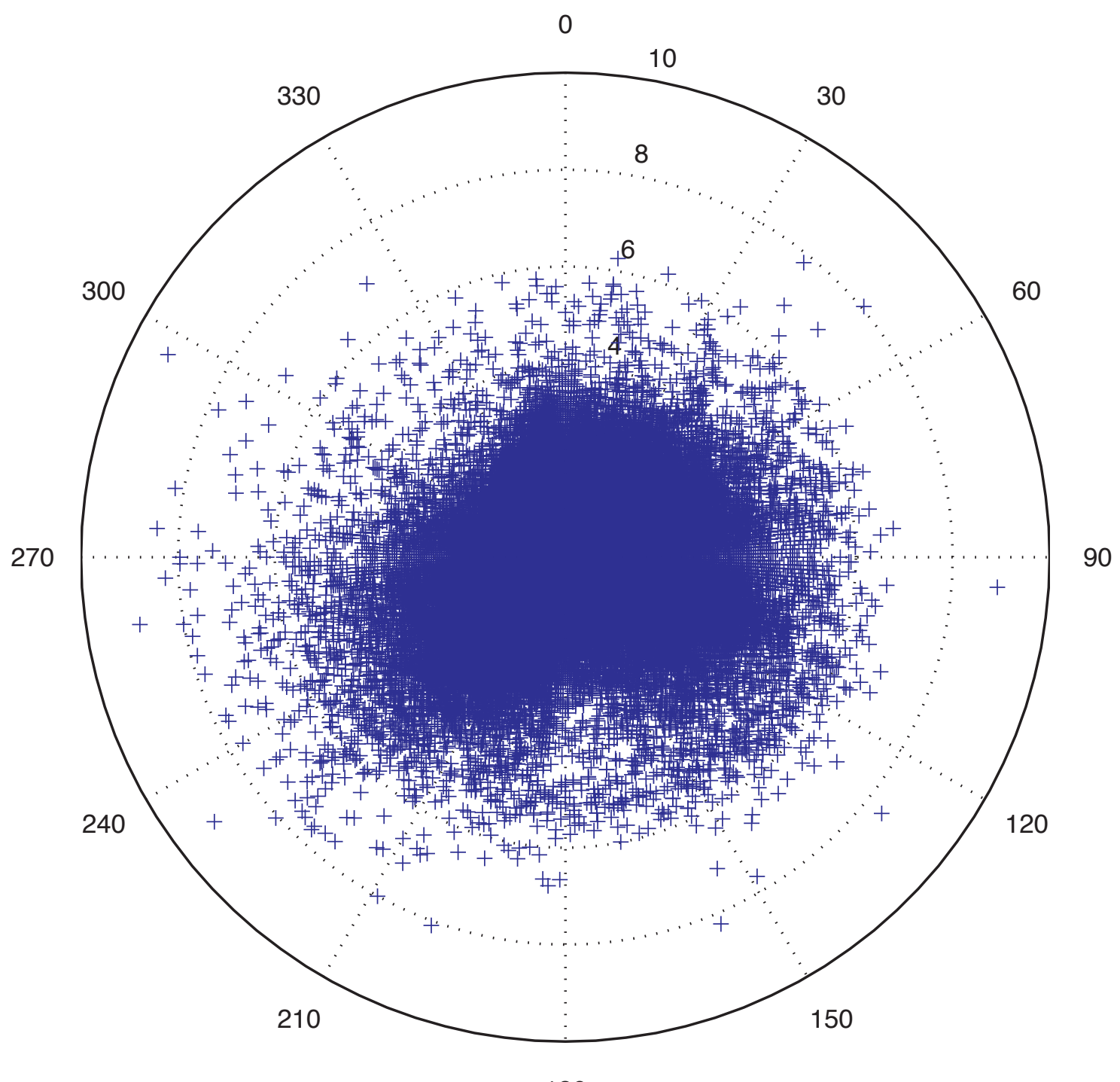

180

Figure 6. Magnitude and direction of wind velocity measured at the instrument station AZ C:05:0031 L in the Colorado River corridor, Grand Canyon, Ariz., at 4-minute resolution throughout 2008. Magnitude is indicated by the concentric circles, and compass bearing indicates direction from which the wind came. 
STATION AZ C:05:0031 L

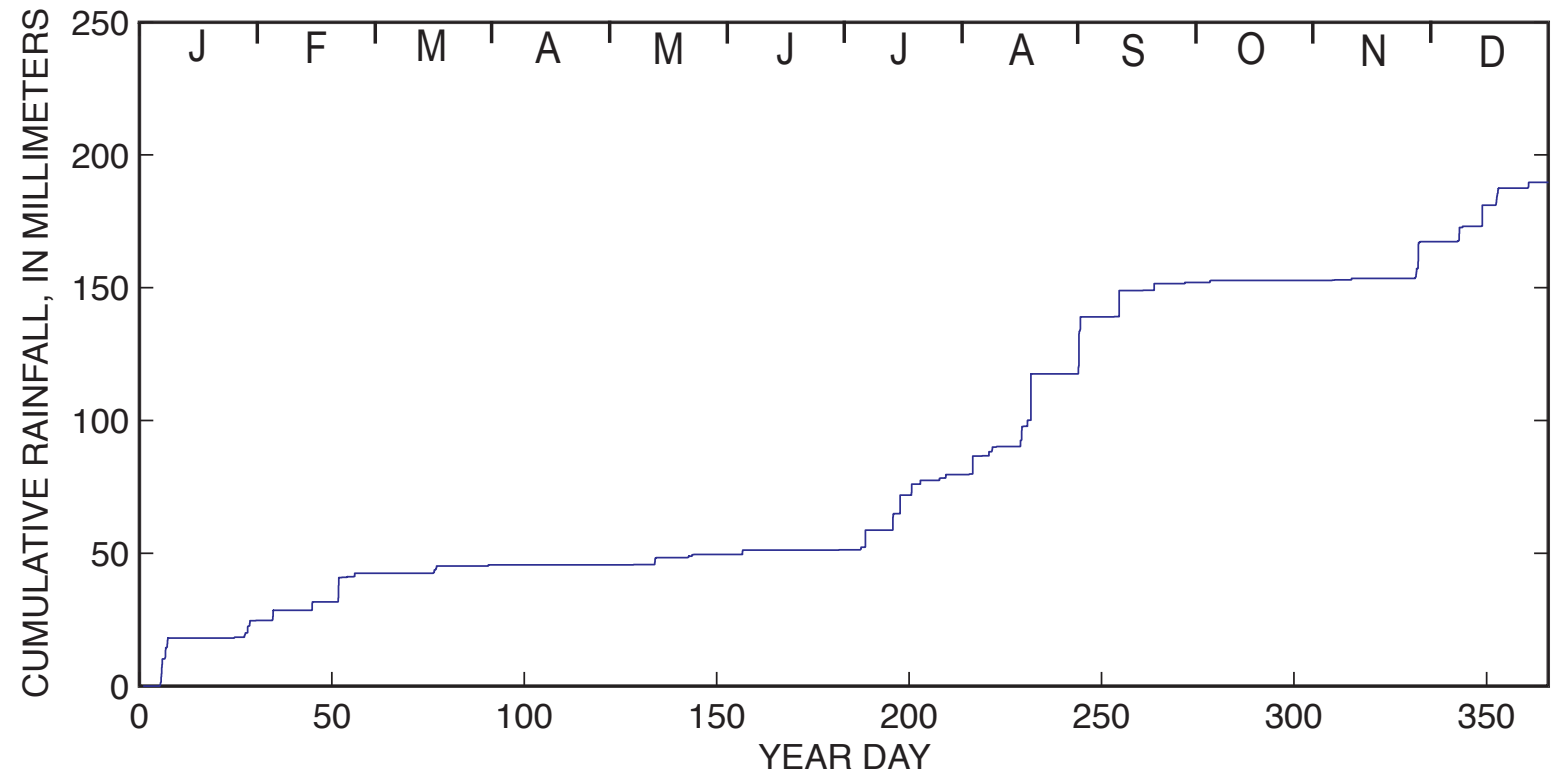

Figure 7. Cumulative 2008 rainfall record measured at AZ C:05:0031 L in the Colorado River corridor, Grand Canyon, Ariz., compiled from data collected at 4-minute resolution. Months are shown as single letter abbreviations at top of figure. 

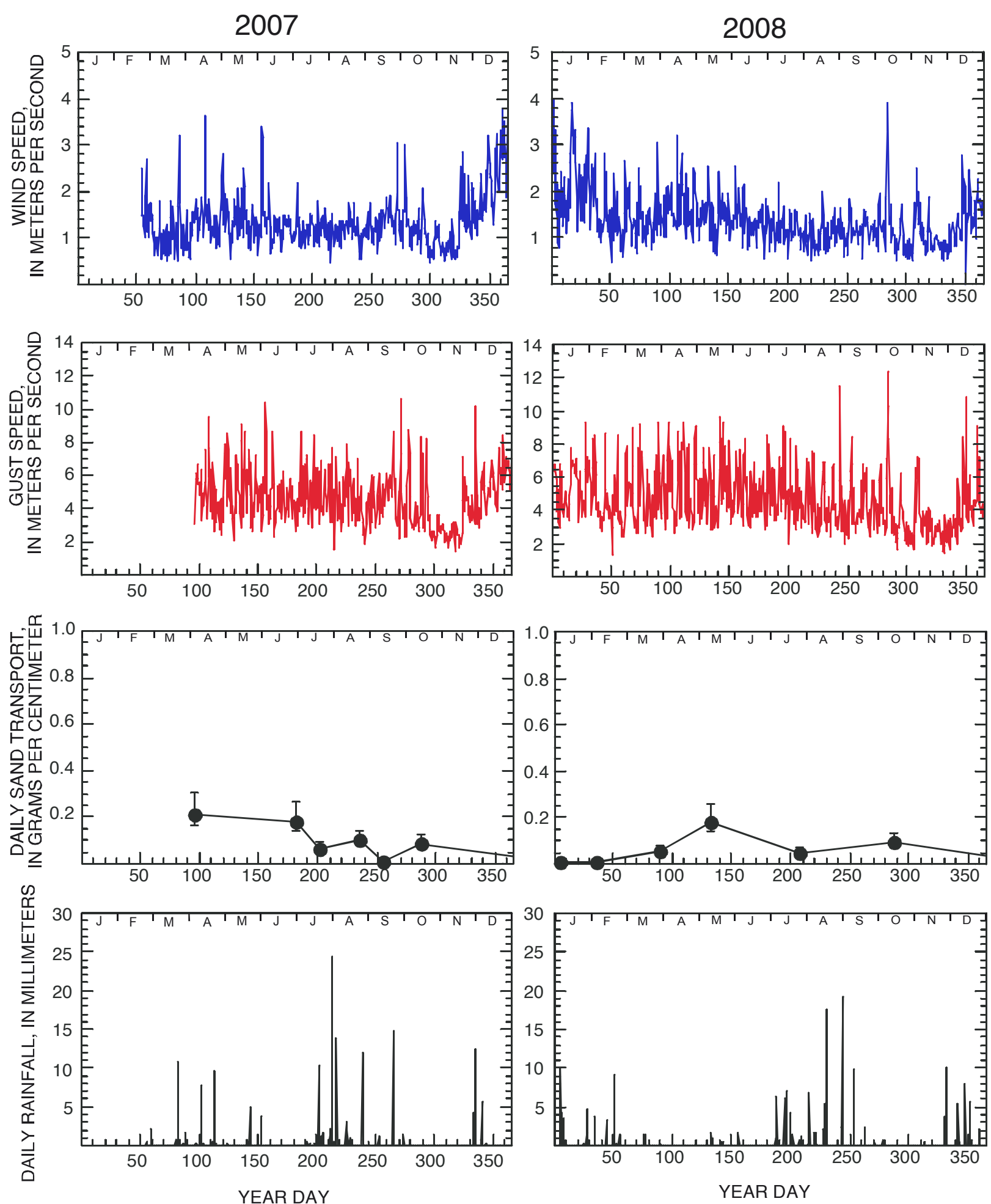

Figure 8. Wind, aeolian sand-transport, and rainfall data collected at the instrument station AZ C:05:0031 L in the Colorado River corridor, Grand Canyon, Ariz., in 2007 and 2008. Daily sand transport is plotted in grams, normalized to a width of $1 \mathrm{~cm}$. To obtain these values, total sand mass collected from four traps during each maintenance visit was divided by number of days since traps had last been emptied. Wind speed (blue plot), is presented as diurnal average values, using daytime (0600-1800 h) and nighttime (1800-0600 h) averages of data collected at 4-minute intervals. Gust speed (red plot) is shown as maximum values that occurred during each diurnal interval. Rainfall is plotted as daily (24-hour) totals. Months are shown as single letter abbreviations at top of figure. 

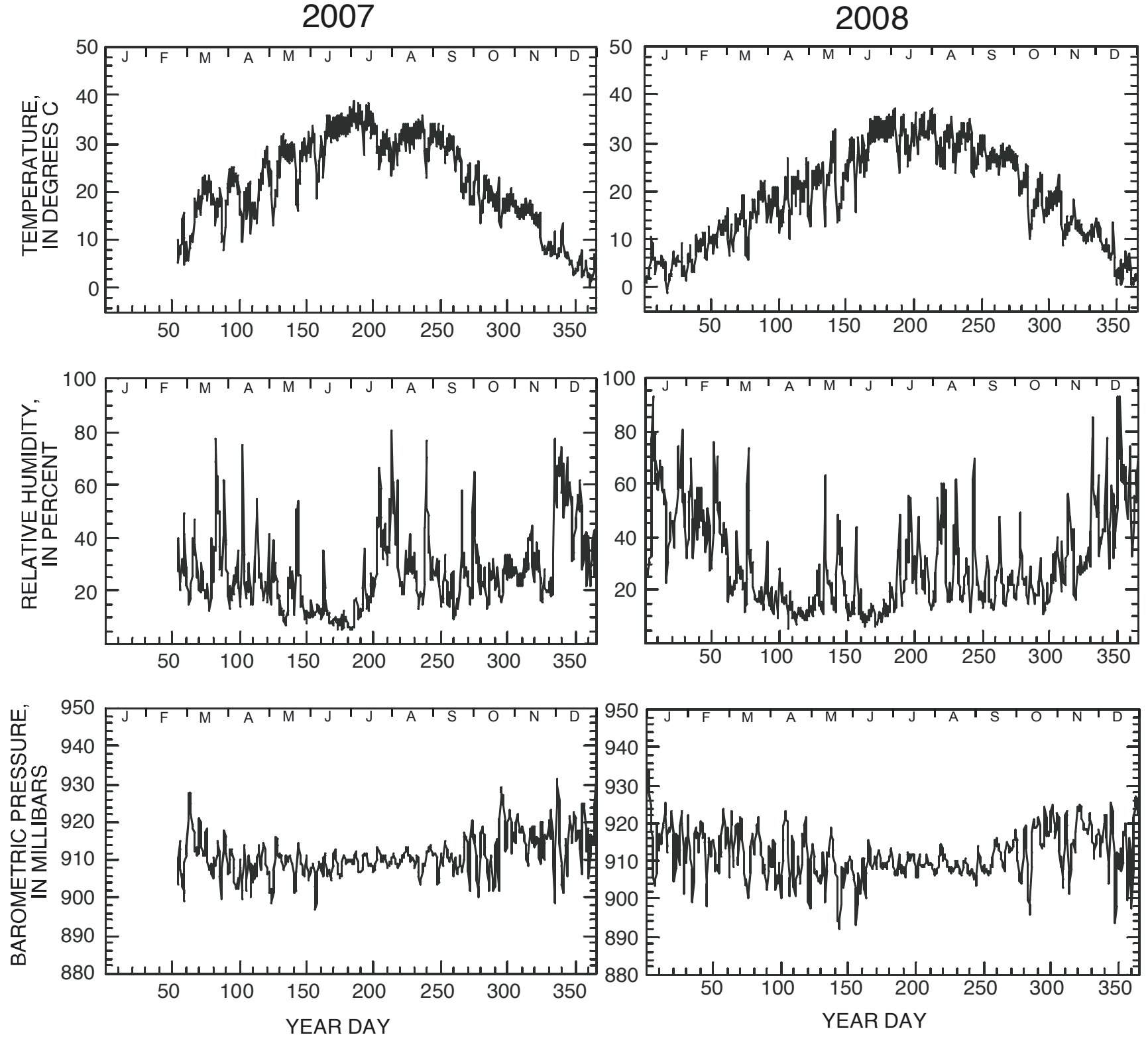

Figure 9. Temperature, humidity, and barometric pressure data collected at the instrument station AZ C:05:0031 L in the Colorado River corridor, Grand Canyon, Ariz., in 2007 and 2008. All parameters are plotted as diurnal averages (defined using 0600-1800 and 1800-0600 hours). Months are shown as single letter abbreviations at top of figure. 


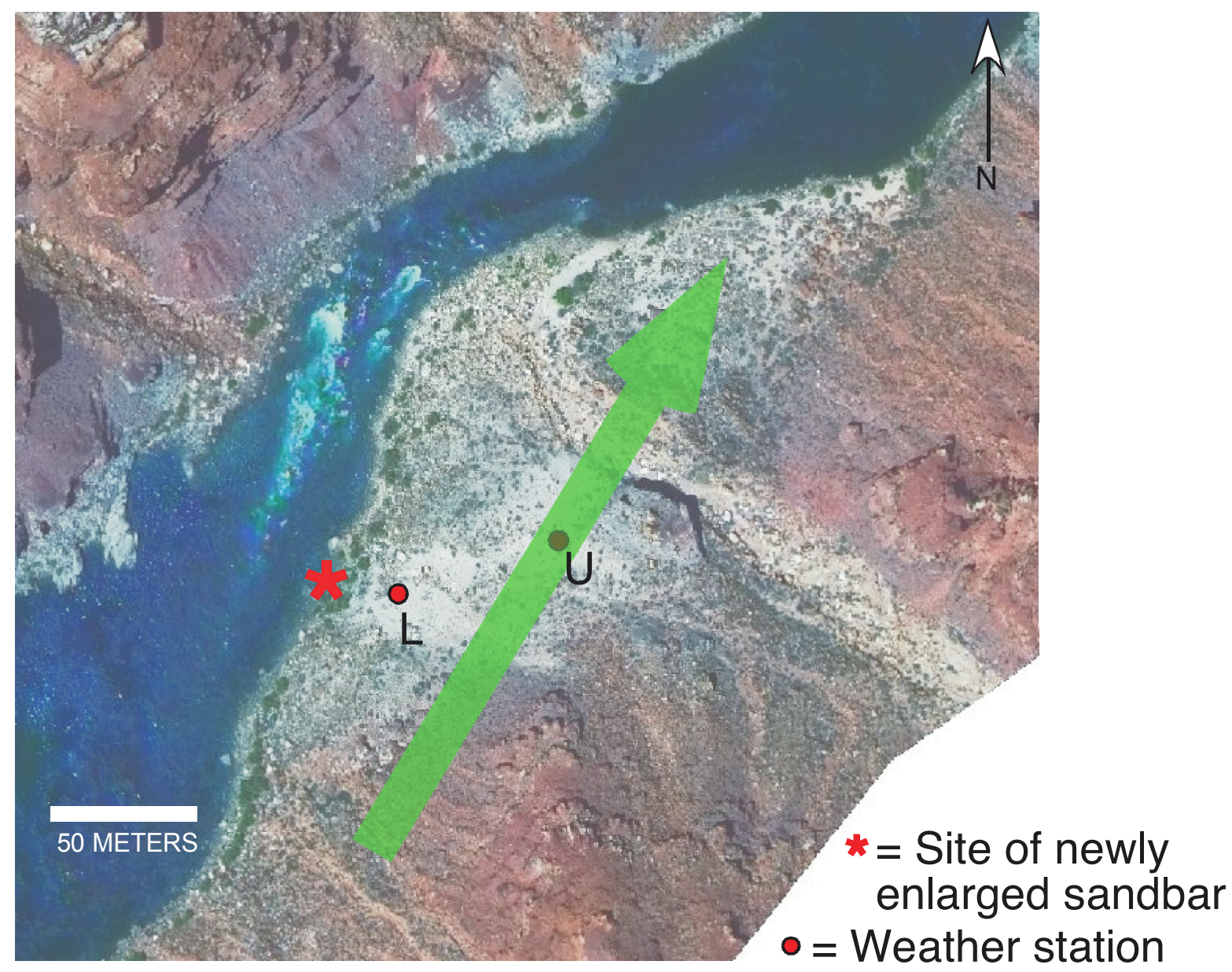

Figure 10. Aerial photograph of the area around AZ C:05:0031, in Grand Canyon, Ariz., with arrow indicating net direction of potential aeolian sediment transport measured at the instrument station AZ C:05:0031 U in 2008. A vector sum of the Op proxy variable (equation 1), calculated using all available wind data from AZ C:05:0031 U in 2008, indicates net sediment transport from 211 degrees. (USGS photograph.) 


\section{4-MINUTE AVERAGE WIND SPEED, IN METERS PER SECOND AND WIND DIRECTION, IN DEGREES}

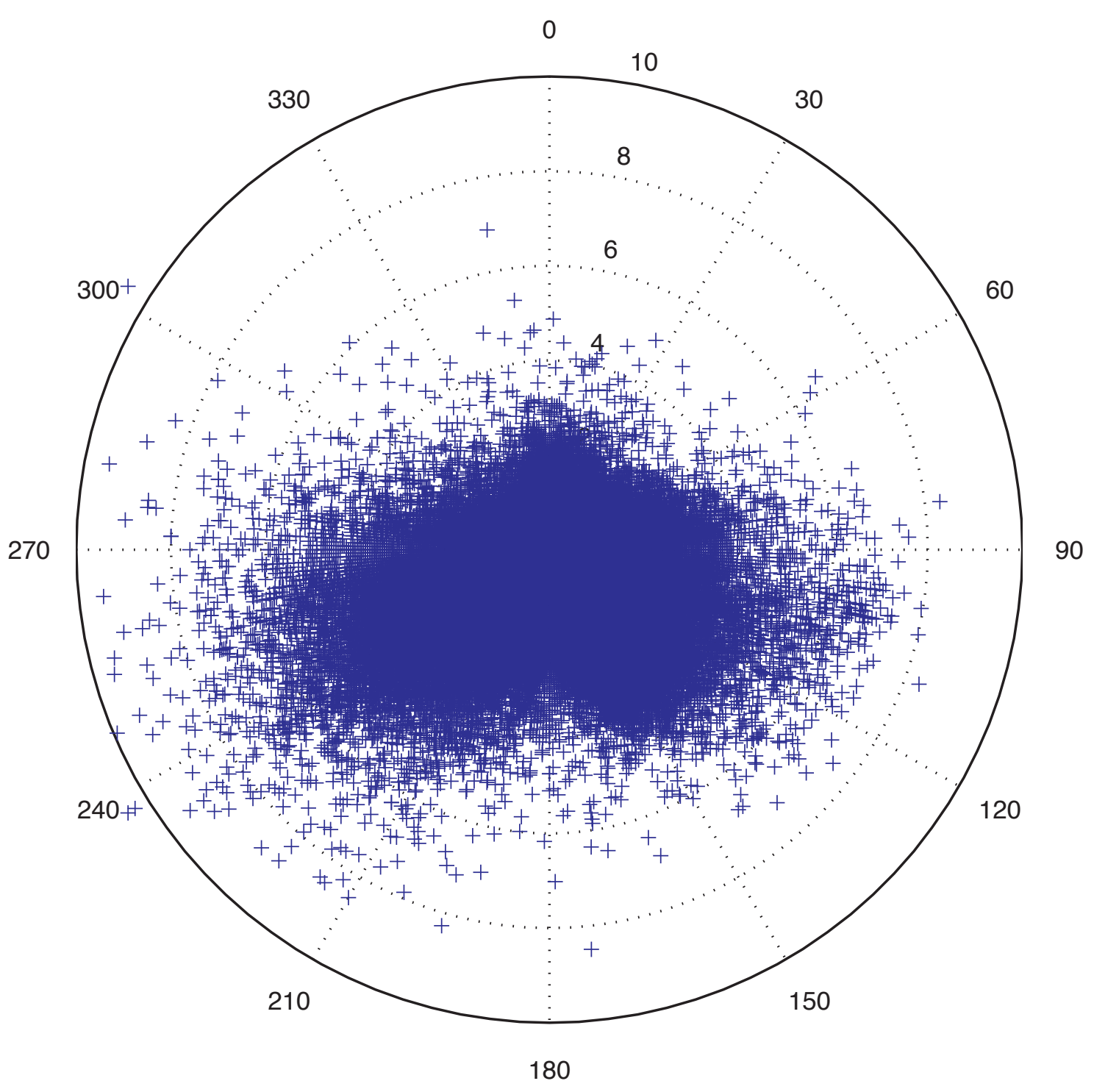

Figure 11. Magnitude and direction of wind velocity measured at the instrument station AZ C:05:0031 U in the Colorado River corridor, Grand Canyon, Ariz., at 4-minute resolution throughout 2008. Magnitude is indicated by the concentric circles, and compass bearing indicates direction from which the wind came. 
STATION AZ C:05:0031 U

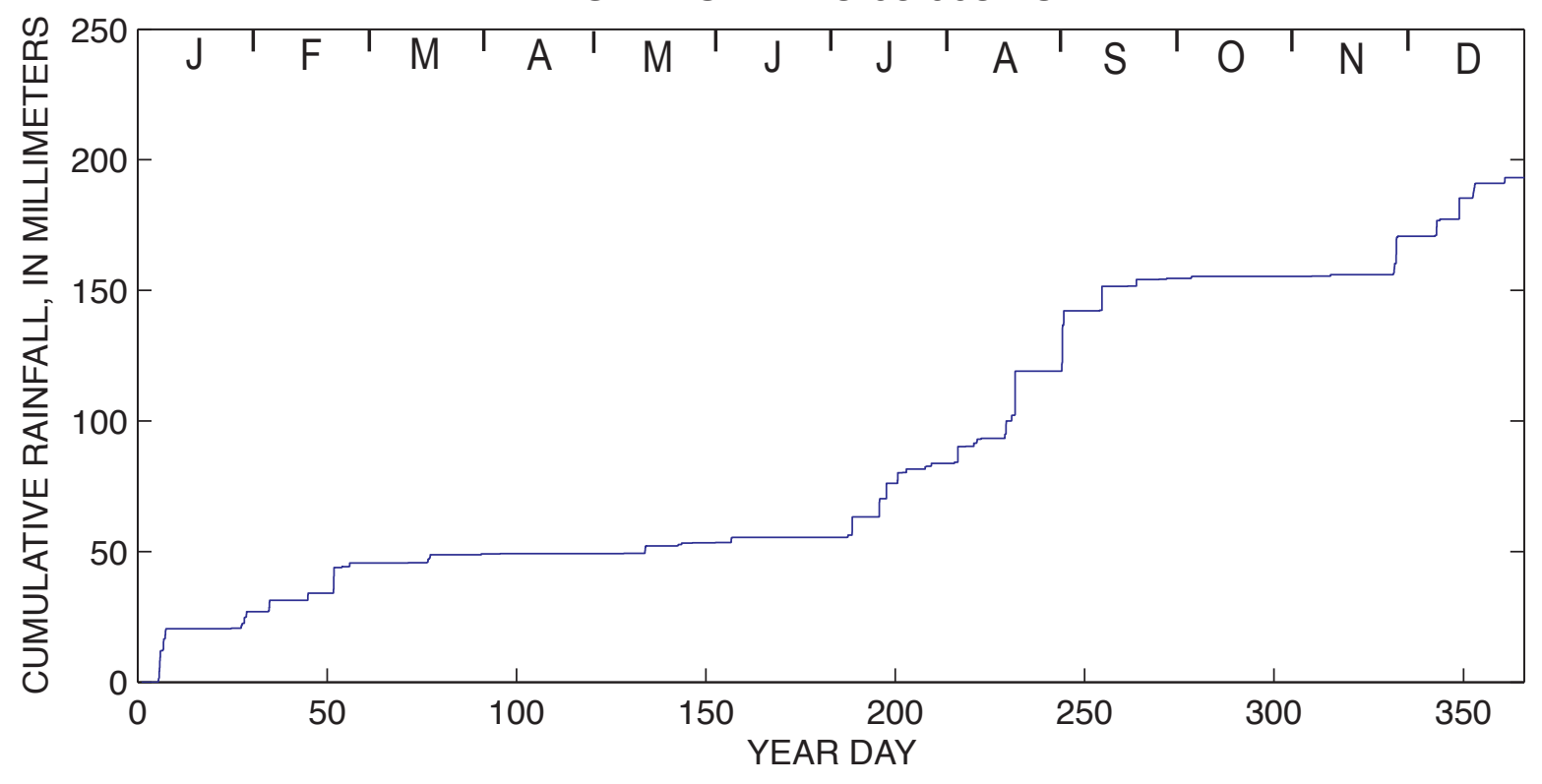

Figure 12. Cumulative 2008 rainfall record measured at AZ C:05:0031 U in the Colorado River corridor, Grand Canyon, Ariz., compiled from data collected at 4-minute resolution. Months are shown as single letter abbreviations at top of figure. 

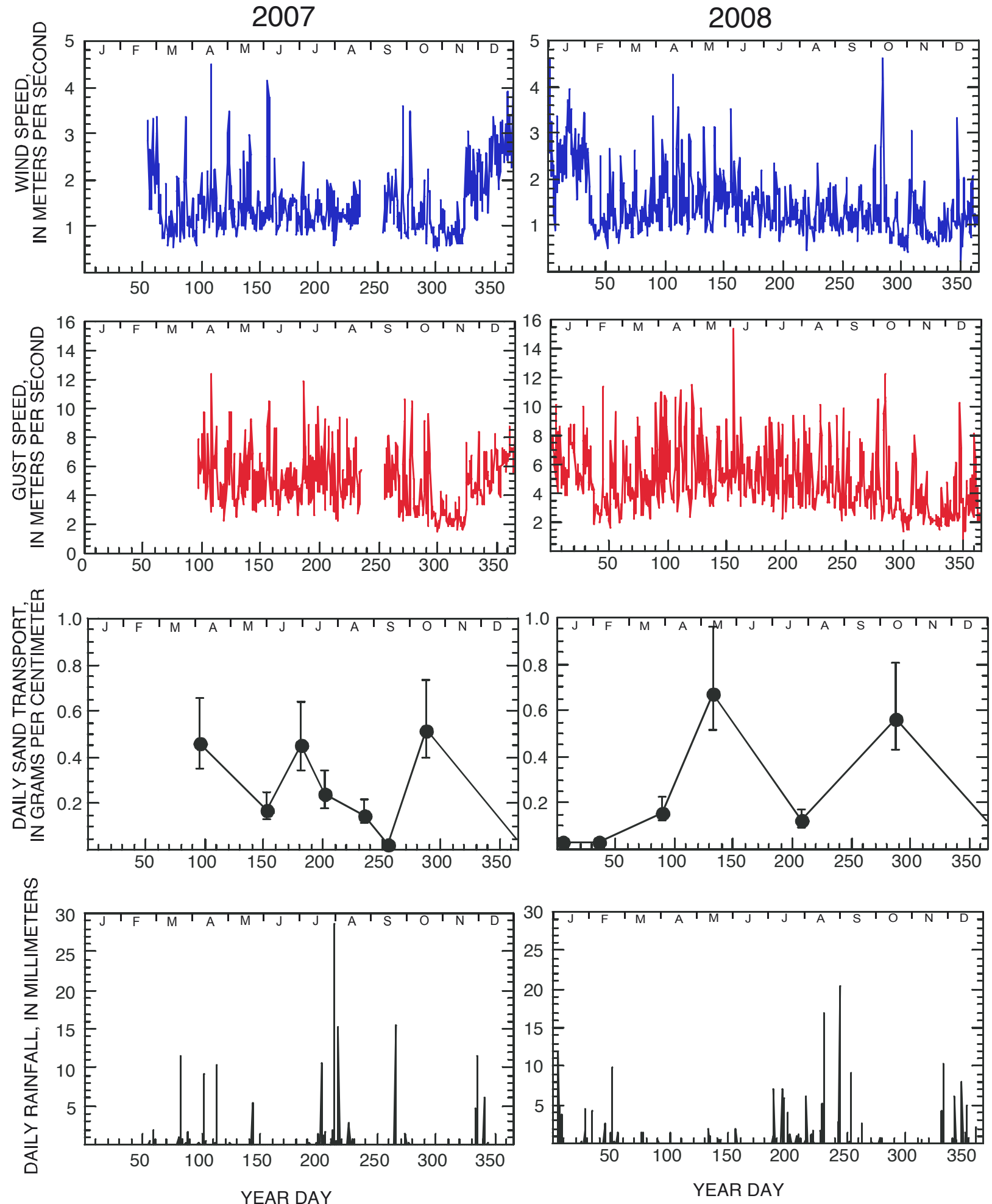

Figure 13. Wind, aeolian sand-transport, and rainfall data collected at the instrument station AZ C:05:0031 U in the Colorado River corridor, Grand Canyon, Ariz., in 2007 and 2008. Daily sand transport is plotted in grams, normalized to a width of $1 \mathrm{~cm}$. To obtain these values, total sand mass collected from four traps during each maintenance visit was divided by number of days since traps had last been emptied. Wind speed (blue plot) is presented as diurnal average values, using daytime (0600-1800 h) and nighttime (1800-0600 h) averages of data collected at 4-minute intervals. Gust speed (red plot) is shown as maximum values that occurred during each diurnal interval. Rainfall is plotted as daily (24-hour) totals. Months are shown as single letter abbreviations at top of figure. 

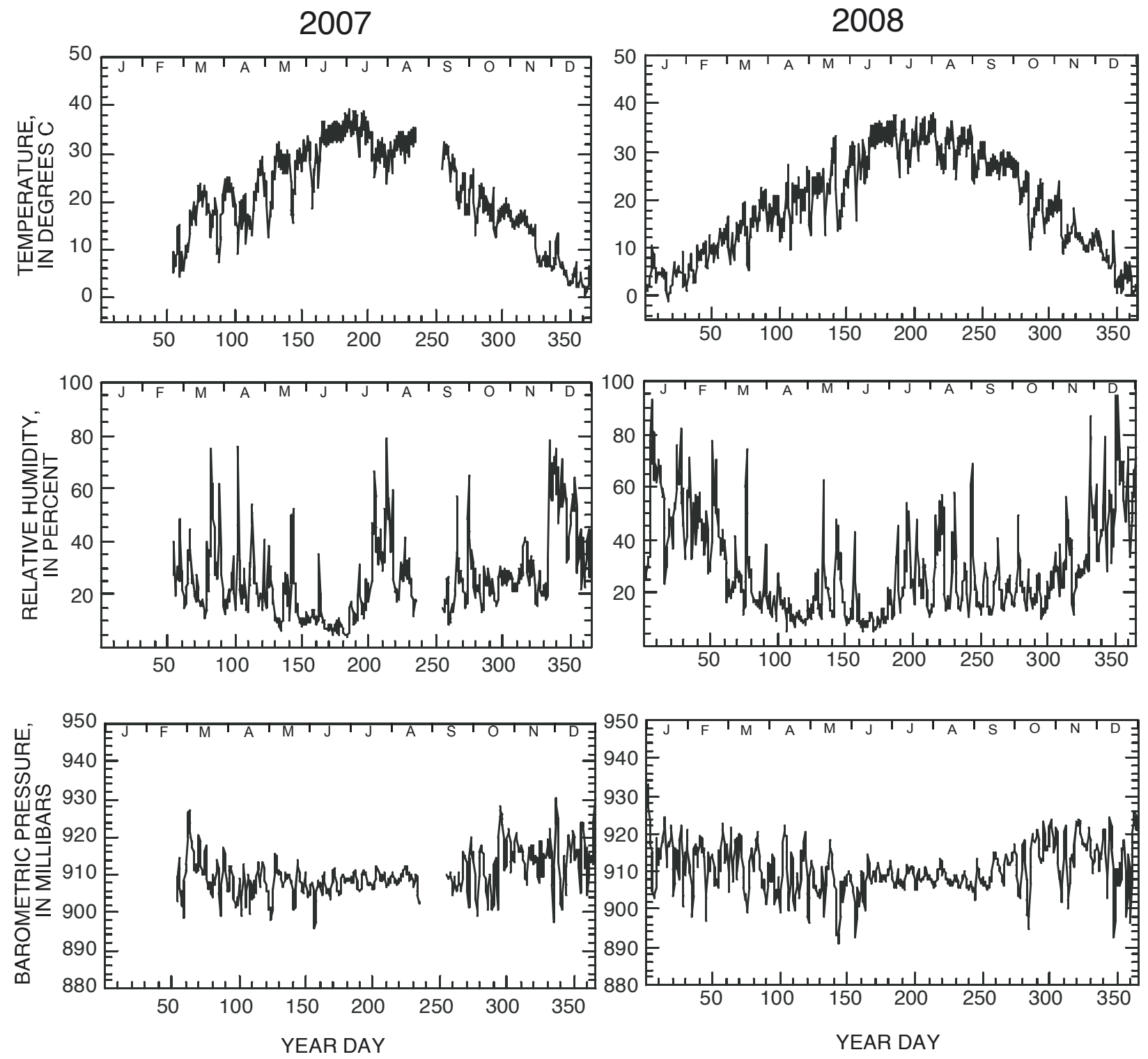

Figure 14. Temperature, humidity, and barometric pressure data collected at the instrument station AZ C:05:0031 U in the Colorado River corridor, Grand Canyon, Ariz., in 2007 and 2008. All parameters are plotted as diurnal averages (defined using 0600-1800 and 1800-0600 hours). Months are shown as single letter abbreviations at top of figure. 

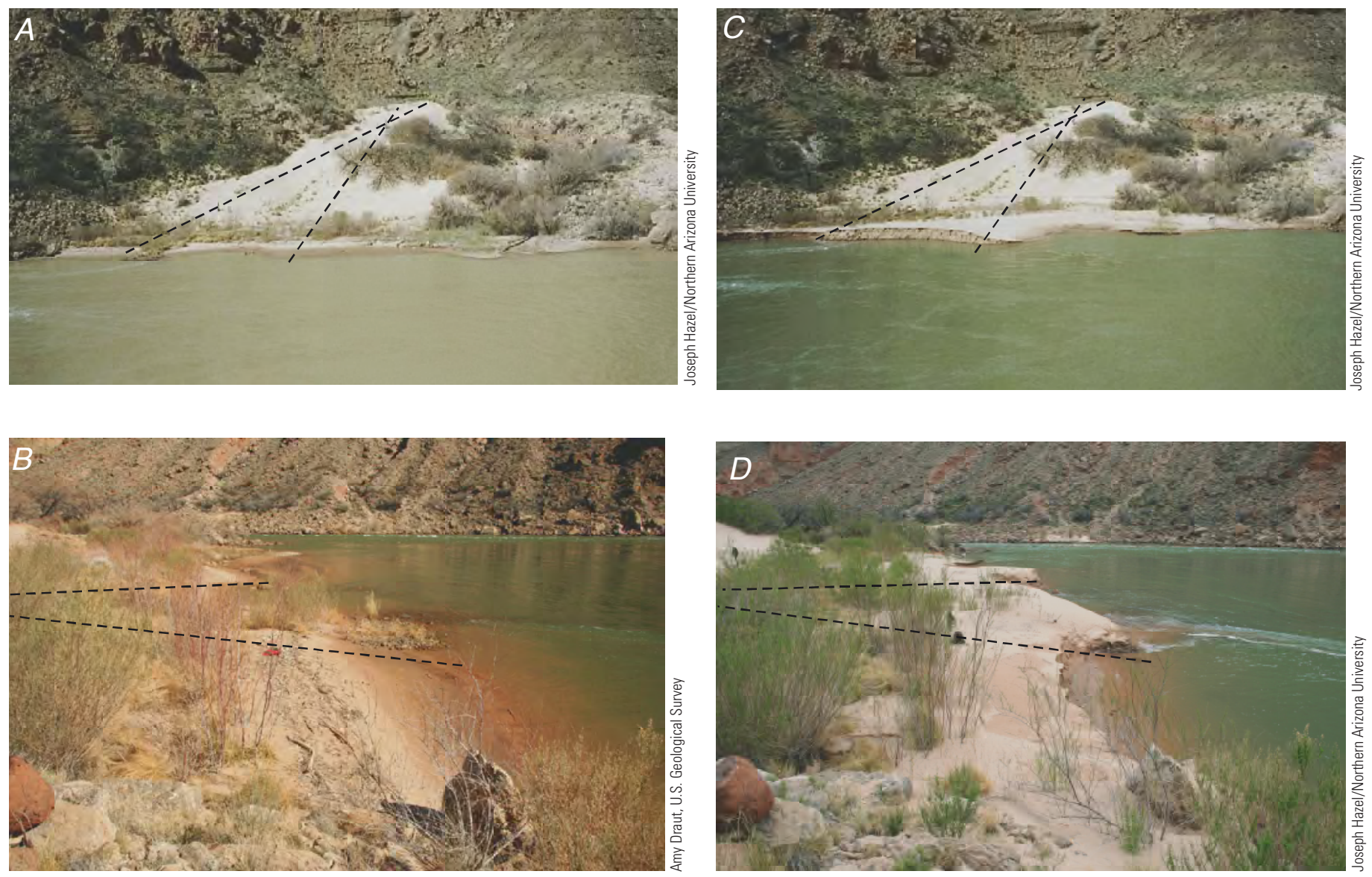

Figure 15. Photographs of the sandbar near AZ C:13:0365 before $(A, B)$ and after $(C, D)$ the 2008 high-flow experiment (HFE). $A$ and $B$ were taken on February 9, 2008; $C$ and $D$ were taken on April 3, 2008. The dashed lines on each photograph indicate the locations of shore-perpendicular topographic profiles shown in figure 17. 


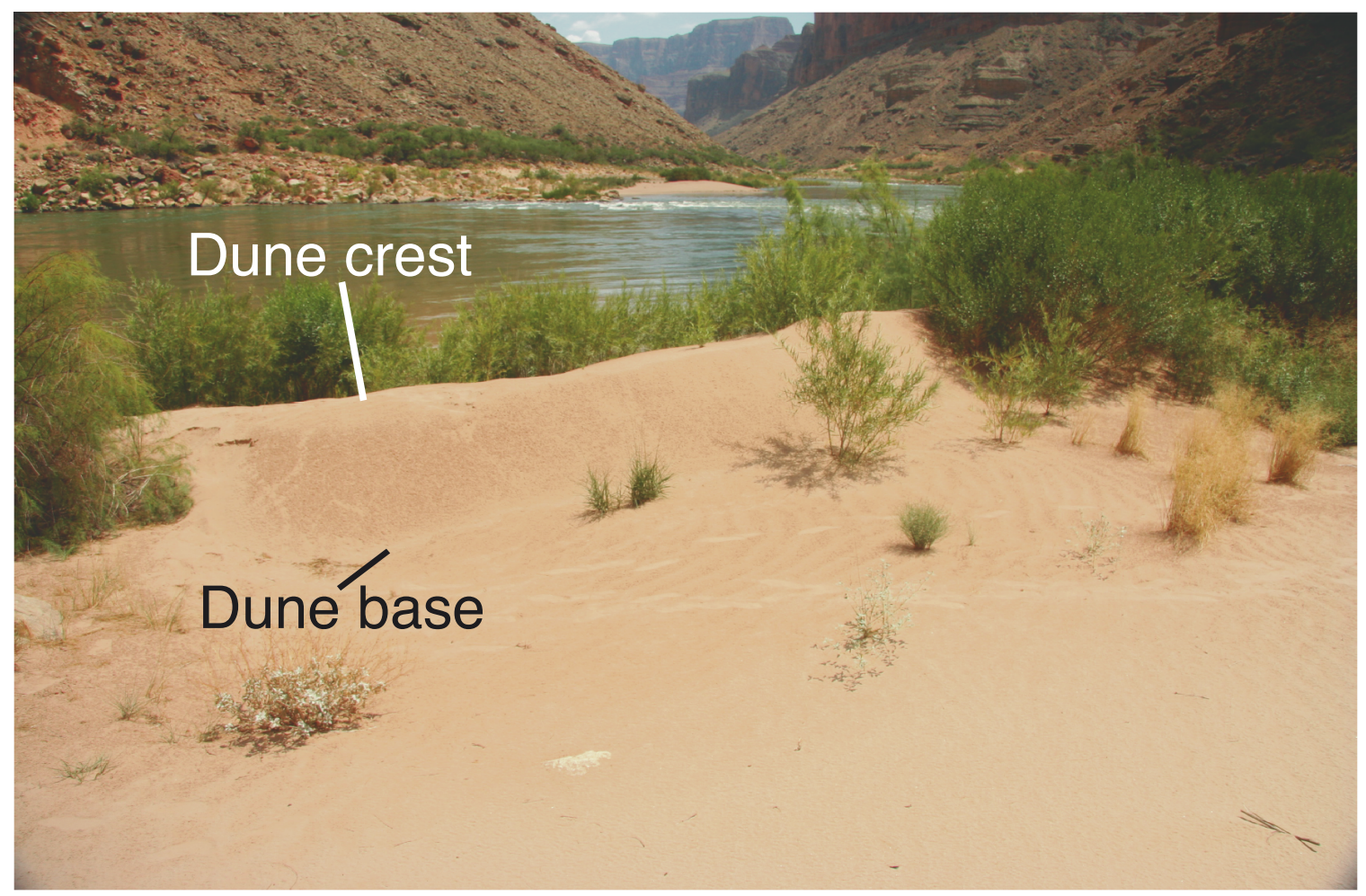

Figure 16. Photograph of an aeolian dune near AZ C:13:0365 that formed on sand deposited by the March 2008 high-flow experiment (HFE). The photograph, taken on July 29, 2008, shows a dune crest approximately $1 \mathrm{~m}$ high with an orientation indicating sand moving inland from the river toward larger, well established aeolian dunes. This dune-migration direction is consistent with the orientation of wind ripples visible on the sediment in the foreground of the photograph, and with the dominant wind direction measured at stations AZ C:13:0365 L and AZ C:13:0365 U. (USGS photograph by Amy Draut.) 

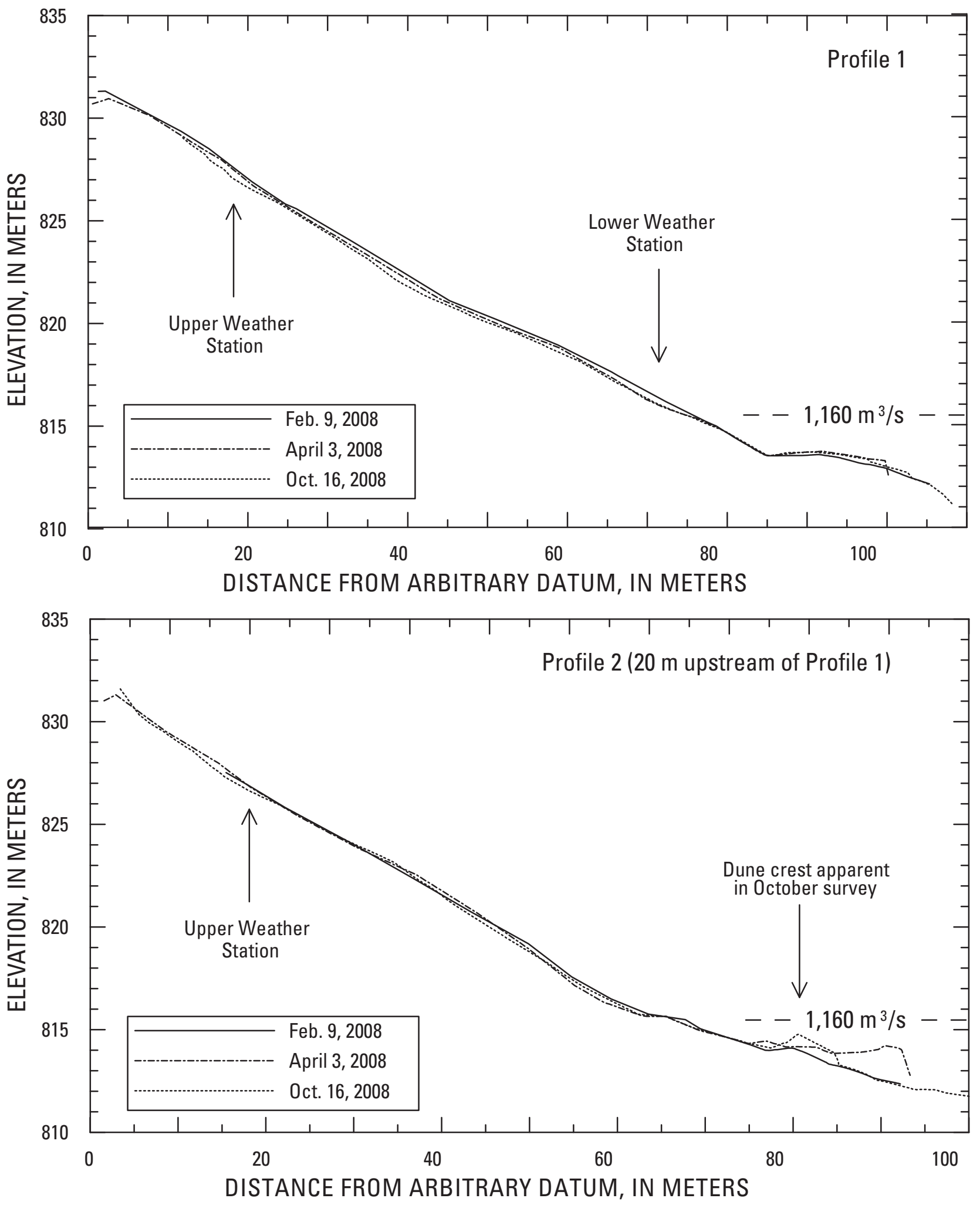

Figure 17. Surveyed profiles of the sandbar near AZ C:13:0365 before and after the 2008 high-flow experiment (HFE). The dune crest in figure 16 is evident in profile 2 . The elevation of the HFE peak stage is indicated $\left(1,160 \mathrm{~m}^{3} / \mathrm{s}\right)$. Profiles trend approximately perpendicular to the channel margin; profile 1 trends north-south, profile 2 trends north-northwest. 


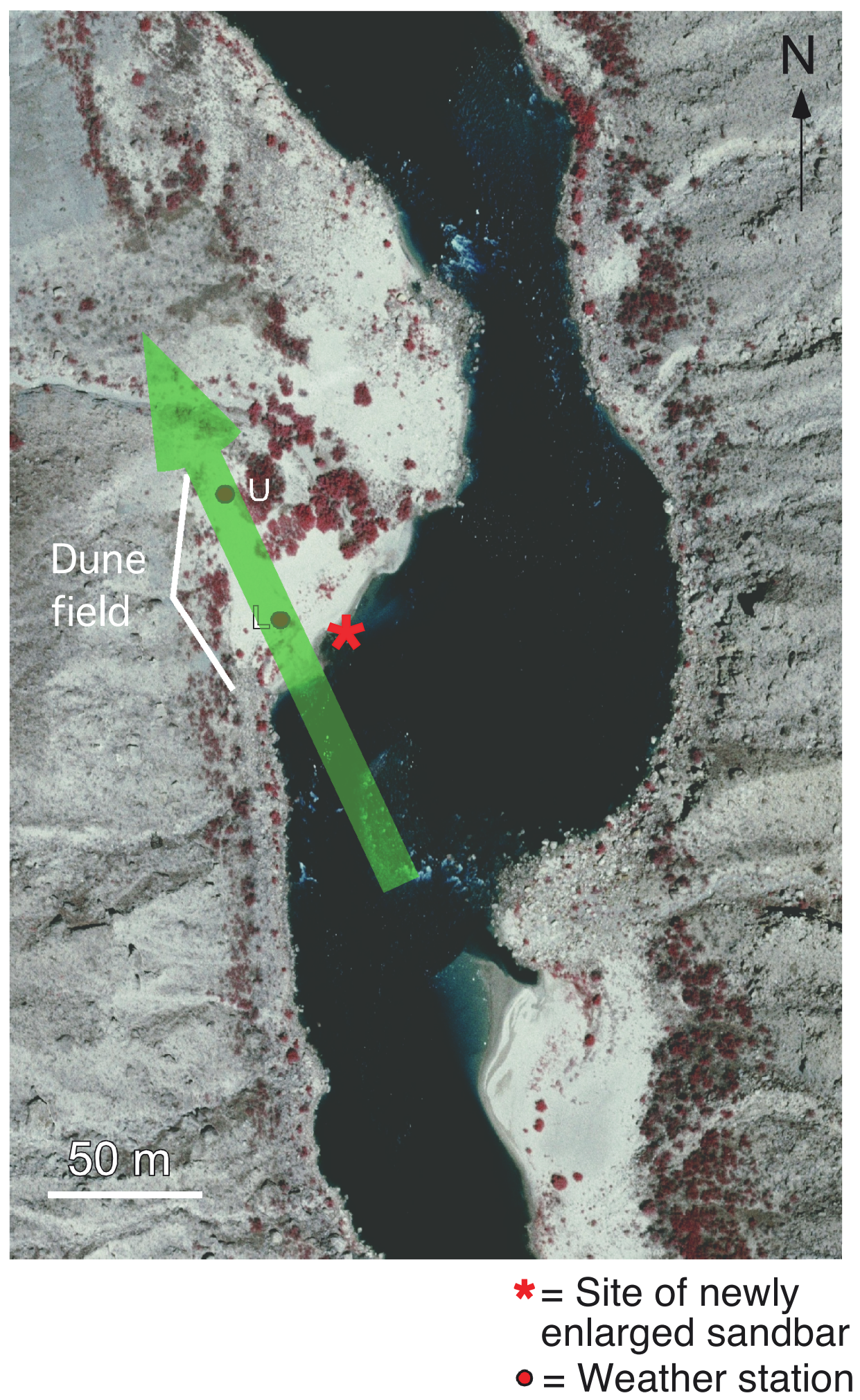

Figure 18. Aerial photograph of the area around AZ C:13:0365, in Grand Canyon, Ariz., with arrow indicating net direction of potential aeolian sediment transport measured at instrument station AZ C:13:0365 L in 2008. A vector sum of the $0 p$ proxy variable (equation 1), calculated using all available wind data from AZ C:13:0365 L in 2008, indicates net sediment transport from 152 degrees. (USGS photograph.) 


\section{4-MINUTE AVERAGE WIND SPEED, IN METERS PER SECOND AND WIND DIRECTION, IN DEGREES}

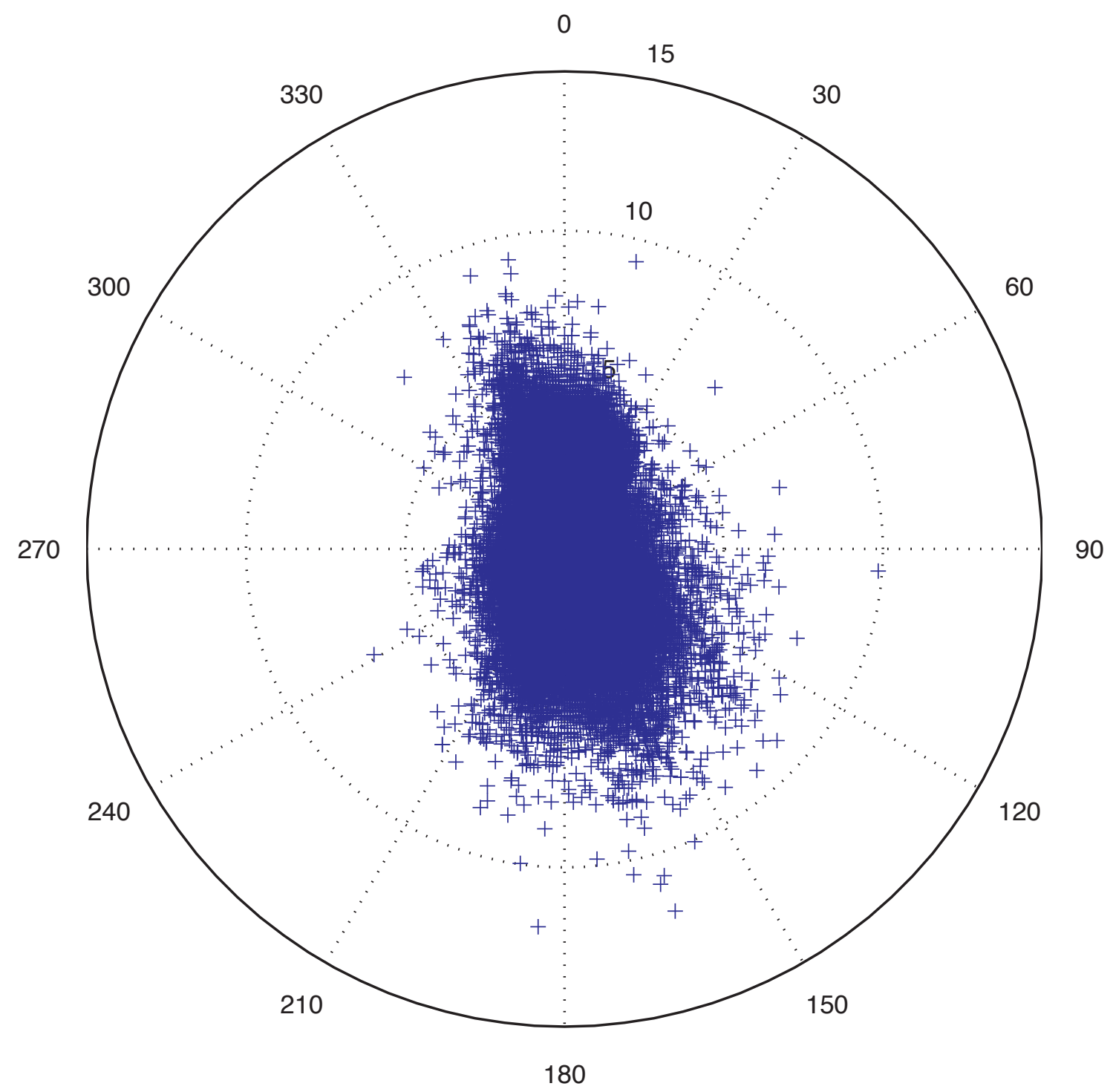

Figure 19. Magnitude and direction of wind velocity measured at the instrument station AZ C:13:0365 L in the Colorado River corridor, Grand Canyon, Ariz., at 4-minute resolution throughout 2008. Magnitude is indicated by the concentric circles, and compass bearing indicates direction from which the wind came. 
STATION AZ C:13:0365 L

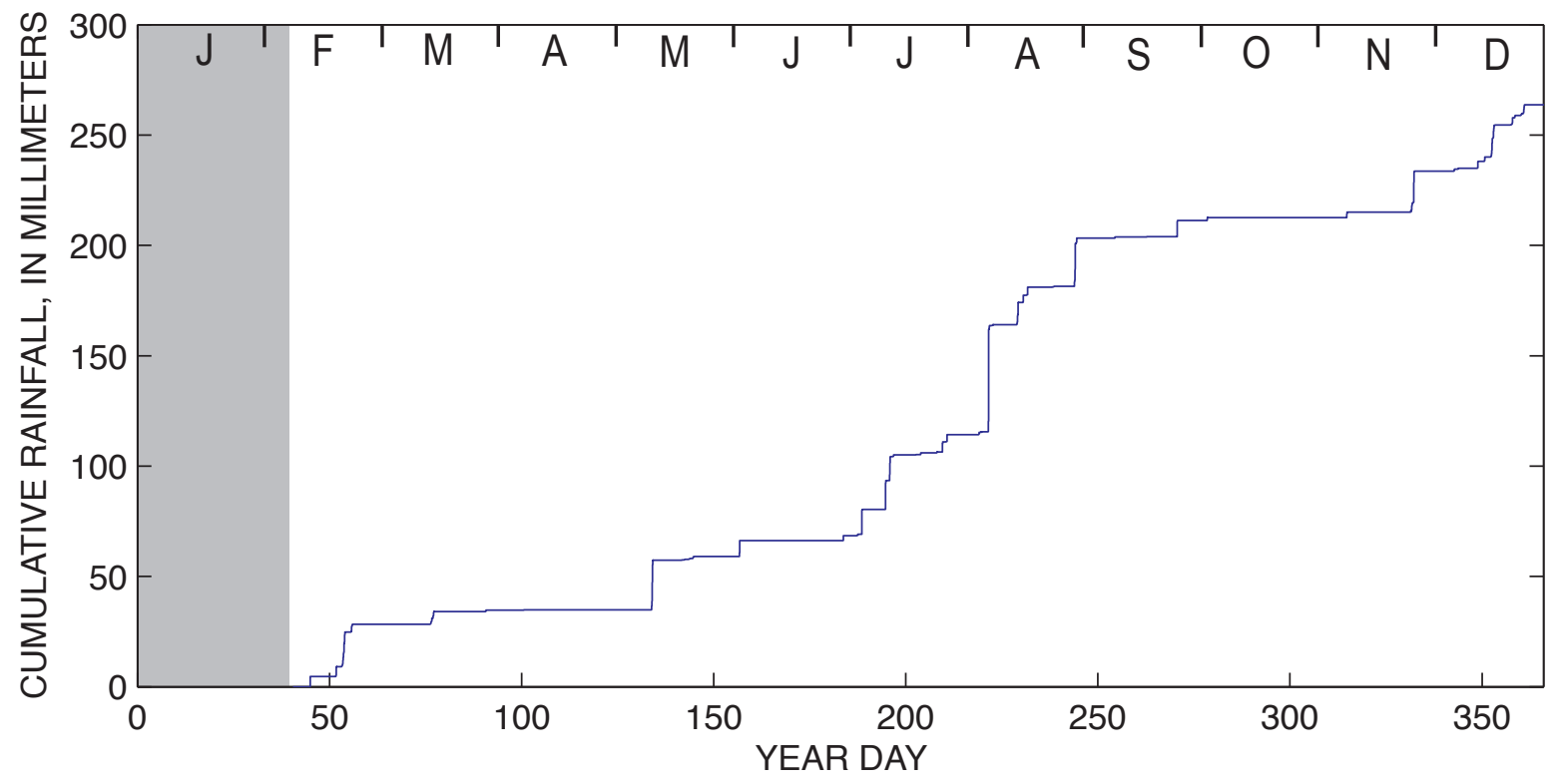

Figure 20. Cumulative 2008 rainfall record measured at AZ C:13:0365 L in the Colorado River corridor, Grand Canyon, Ariz., compiled from data collected at 4-minute resolution. The gray shaded region indicates days when the station was not collecting rainfall data (the station was deployed on February 9, 2008). Months are shown as single letter abbreviations at top of figure. 

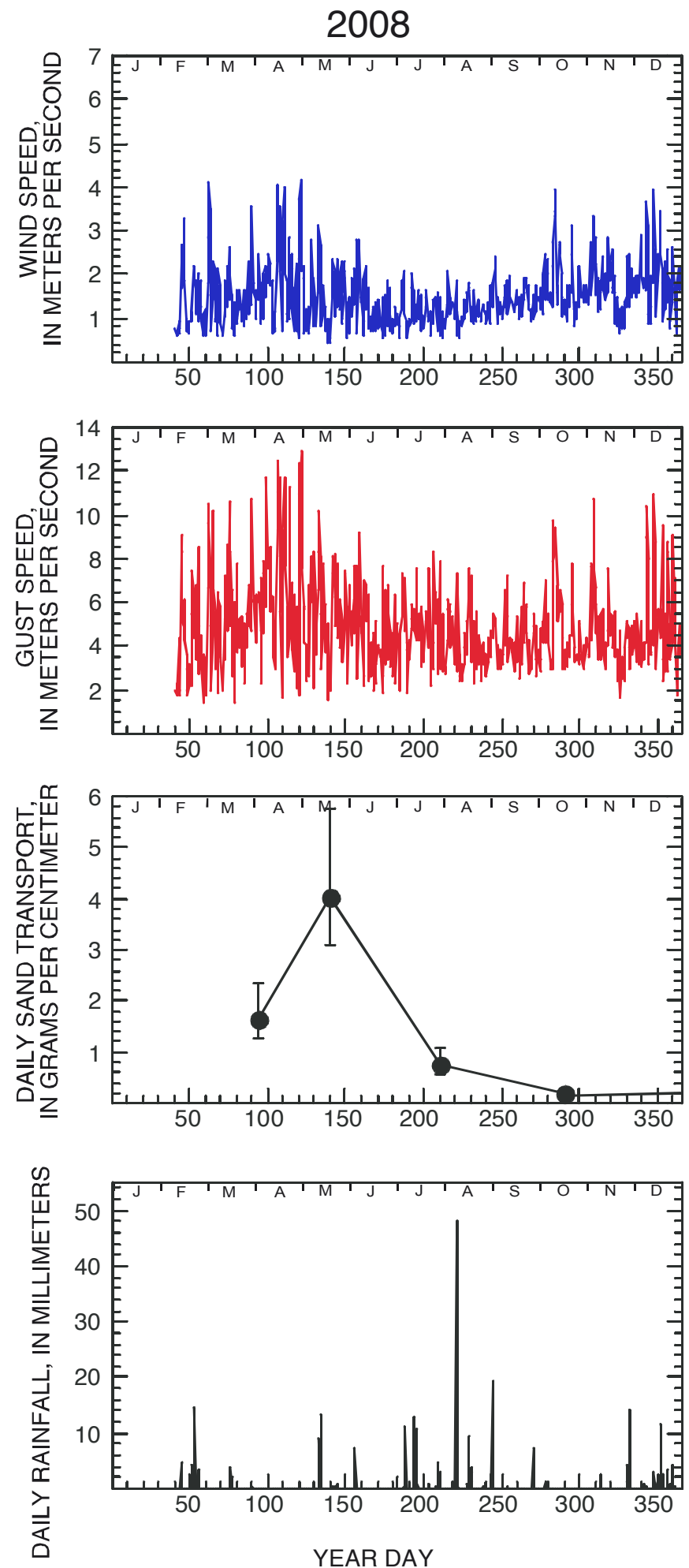

Figure 21. Wind, aeolian sand-transport, and rainfall data collected at the instrument station AZ C:13:0365 L in the Colorado River corridor, Grand Canyon, Ariz., in 2008. Daily sand transport is plotted in grams, normalized to a width of $1 \mathrm{~cm}$. To obtain these values, total sand mass collected from four traps during each maintenance visit was divided by number of days since traps had last been emptied. Wind speed (blue plot) is presented as diurnal average values, using daytime (0600-1800 h) and nighttime (1800-0600 h) averages of data collected at 4-minute intervals. Gust speed (red plot) is shown as maximum values that occurred during each diurnal interval. Rainfall is plotted as daily (24-hour) totals. Months are shown as single letter abbreviations at top of figure. 

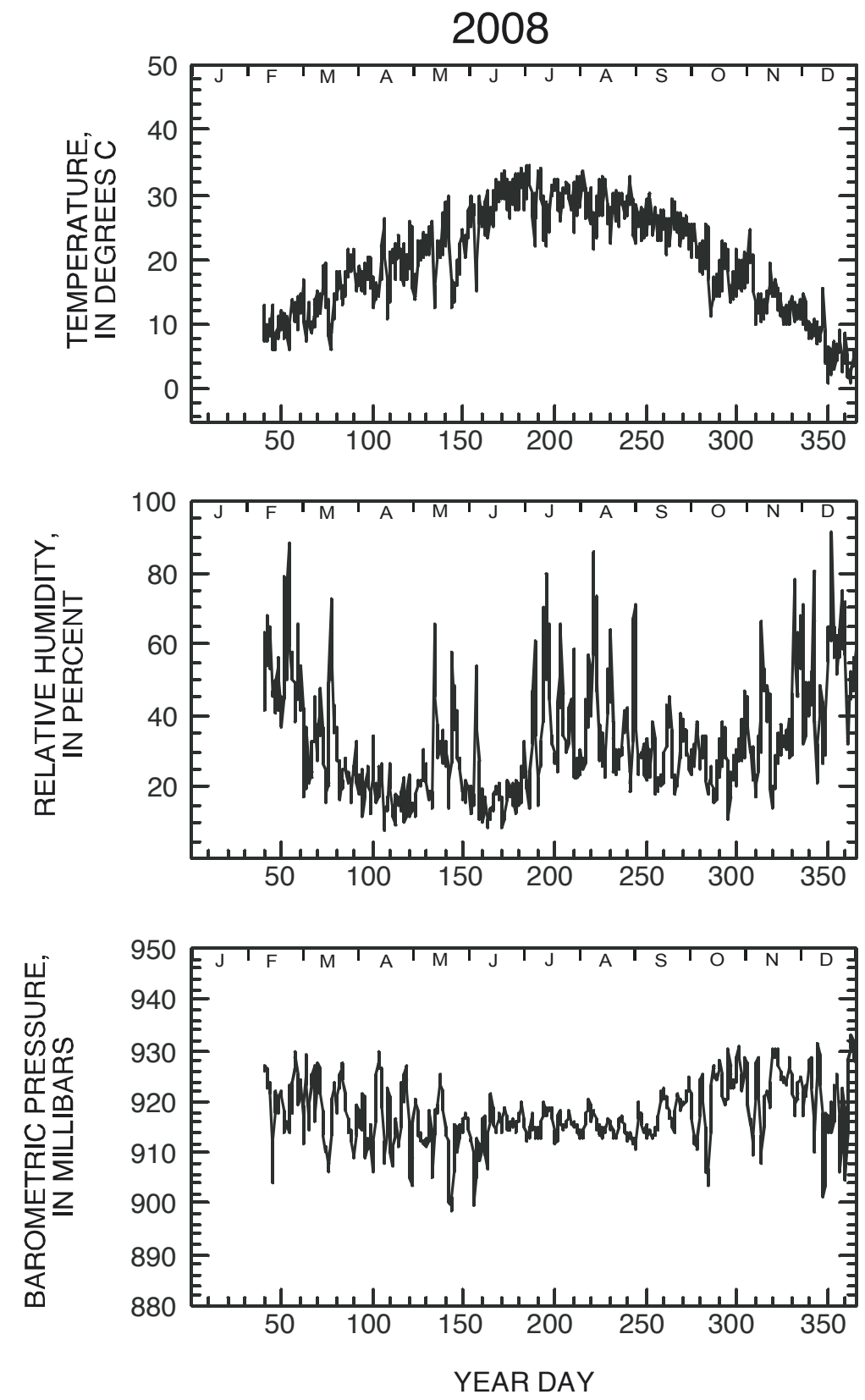

Figure 22. Temperature, humidity, and barometric pressure data collected at the instrument station AZ C:13:0365 L in the Colorado River corridor, Grand Canyon, Ariz., in 2008. All parameters are plotted as diurnal averages (defined using 0600-1800 and 1800-0600 hours). Months are shown as single letter abbreviations at top of figure. 


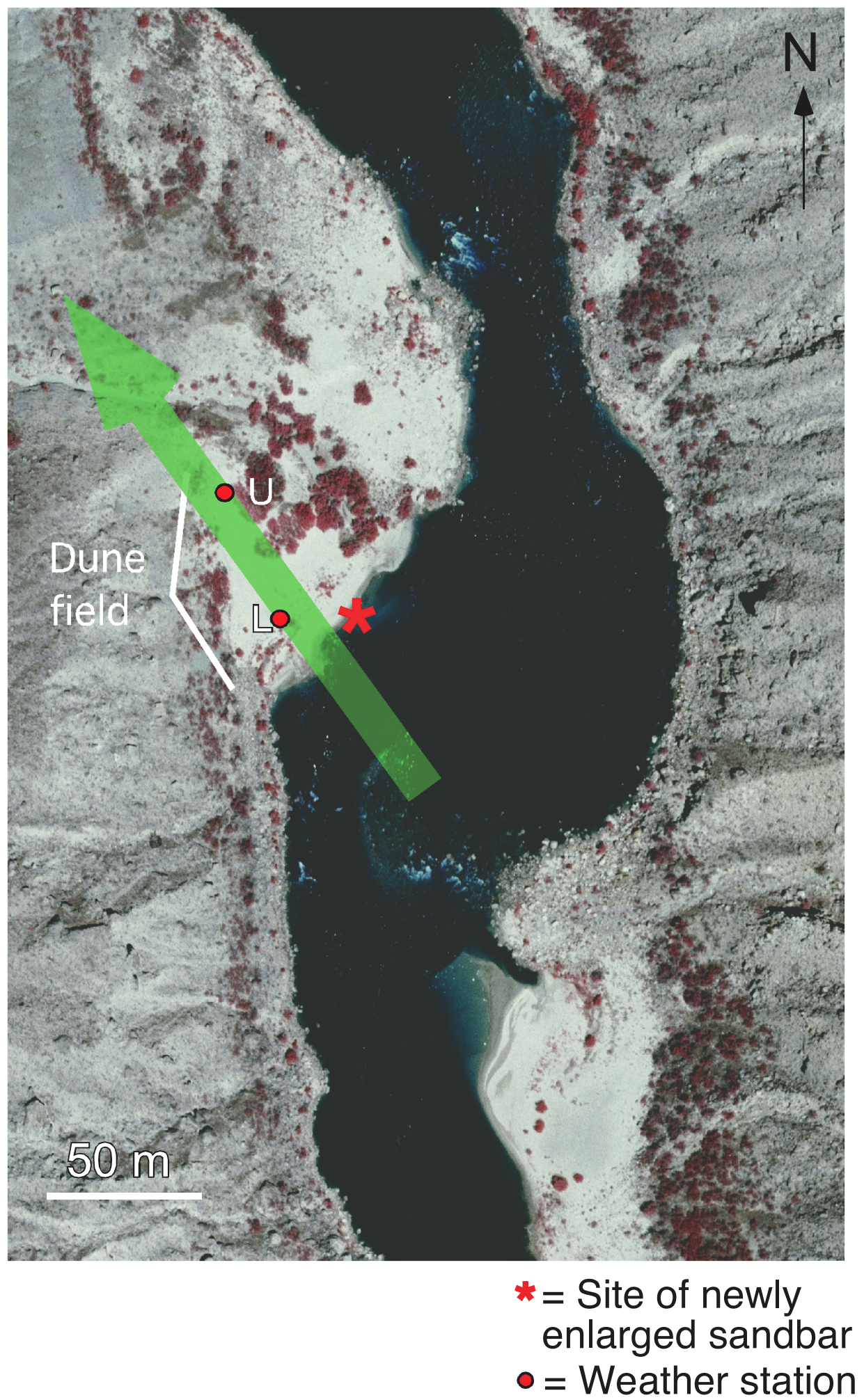

Figure 23. Aerial photograph of the area around AZ C:13:0365, in Grand Canyon, Ariz., with arrow indicating net direction of potential aeolian sediment transport measured at instrument station AZ C:13:0365 U in 2008. A vector sum of the $Q p$ proxy variable (equation 1), calculated using all available wind data from AZ C:13:0365 U in 2008, indicates net sediment transport from 142 degrees. (USGS photograph.) 


\section{4-MINUTE AVERAGE WIND SPEED, IN METERS PER SECOND \\ AND WIND DIRECTION, IN DEGREES}

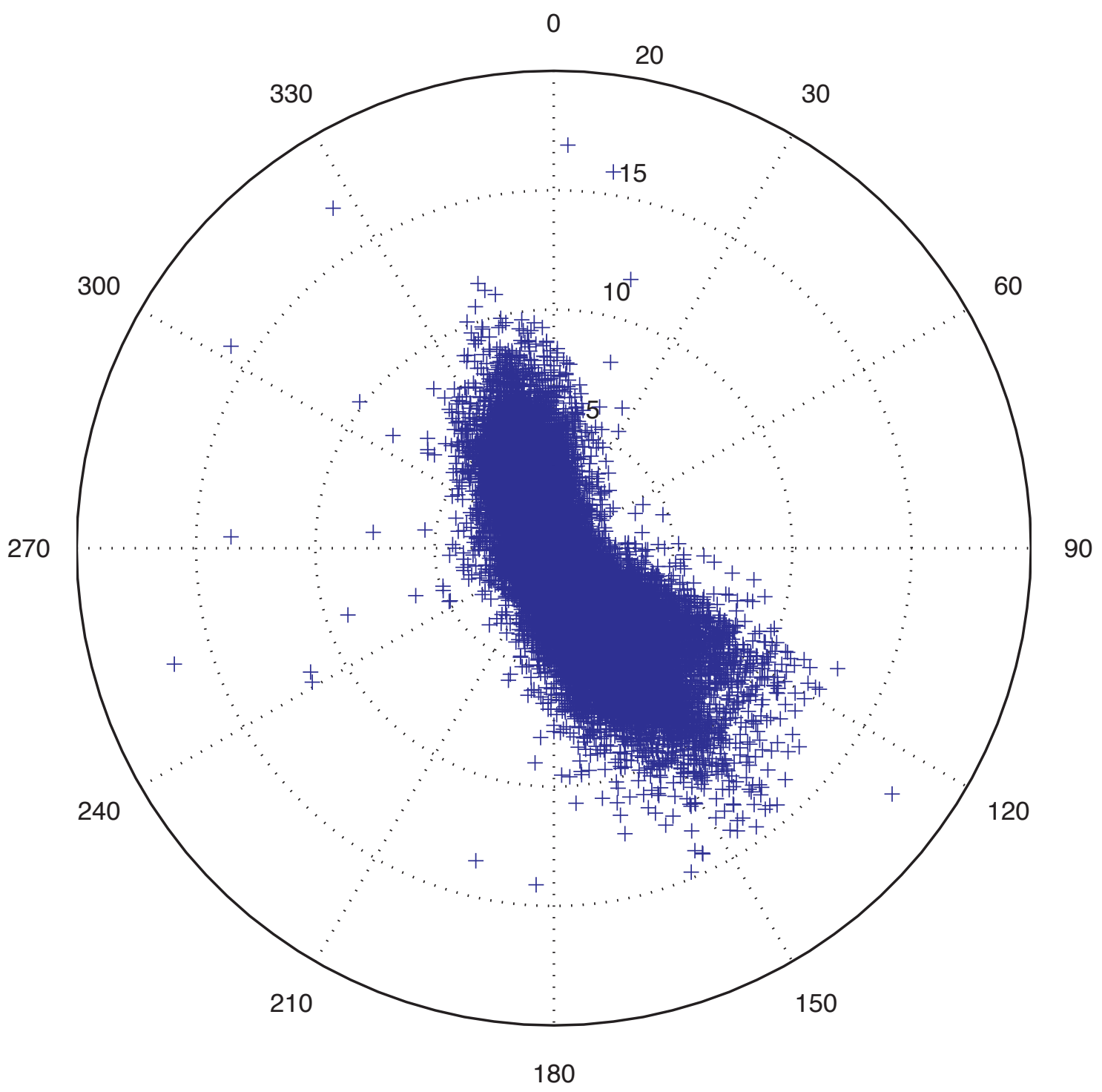

Figure 24. Magnitude and direction of wind velocity measured at the instrument station AZ C:13:0365 U in the Colorado River corridor, Grand Canyon, Ariz., at 4-minute resolution throughout 2008. Magnitude is indicated by the concentric circles, and compass bearing indicates direction from which the wind came. 
STATION AZ C:13:0365 U

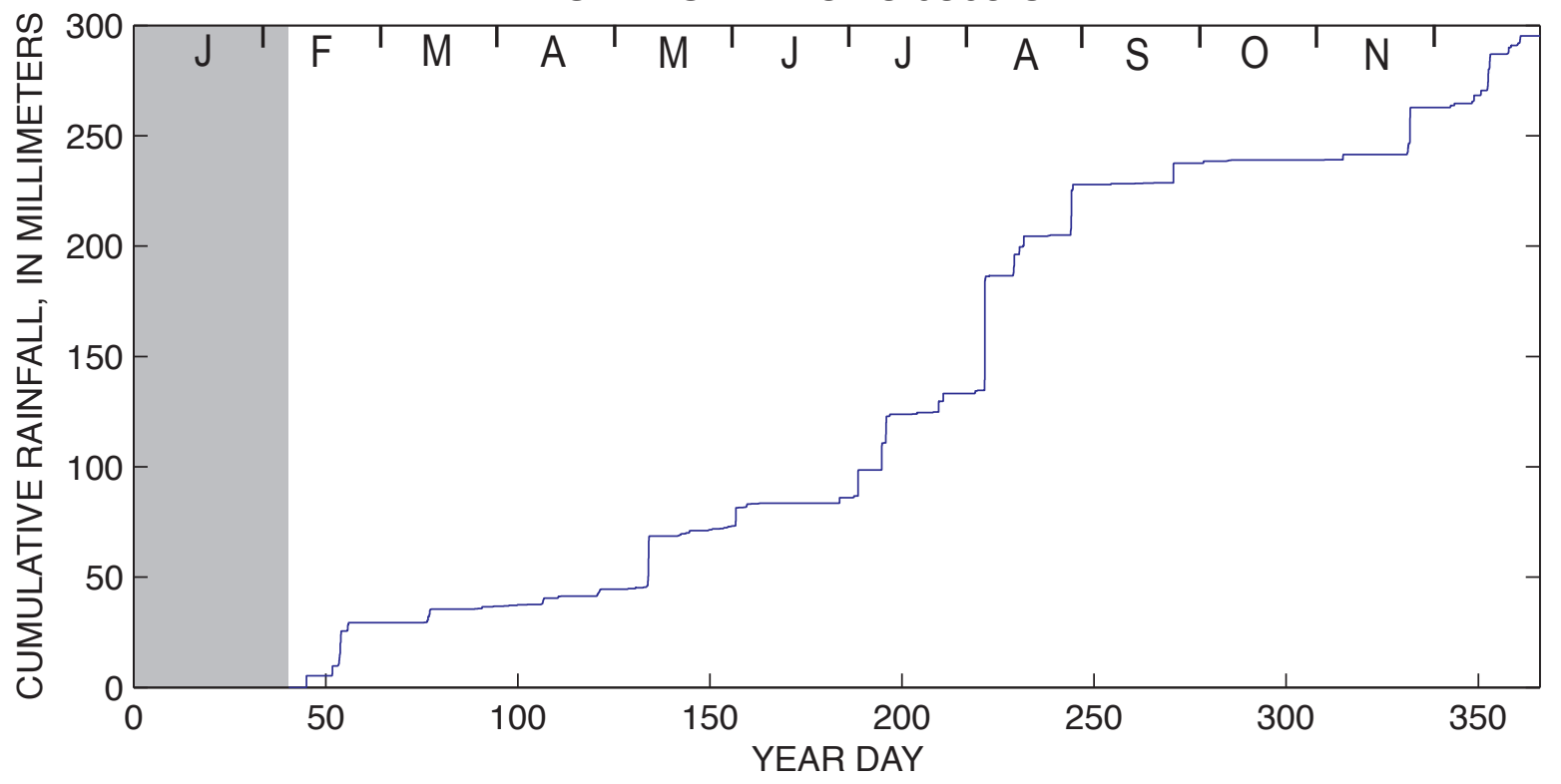

Figure 25. Cumulative 2008 rainfall record measured at AZ C:13:0365 U in the Colorado River corridor, Grand Canyon, Ariz., compiled from data collected at 4-minute resolution. The gray shaded region indicates days when the station was not collecting rainfall data (the station was deployed on February 9, 2008). Months are shown as single letter abbreviations at top of figure. 

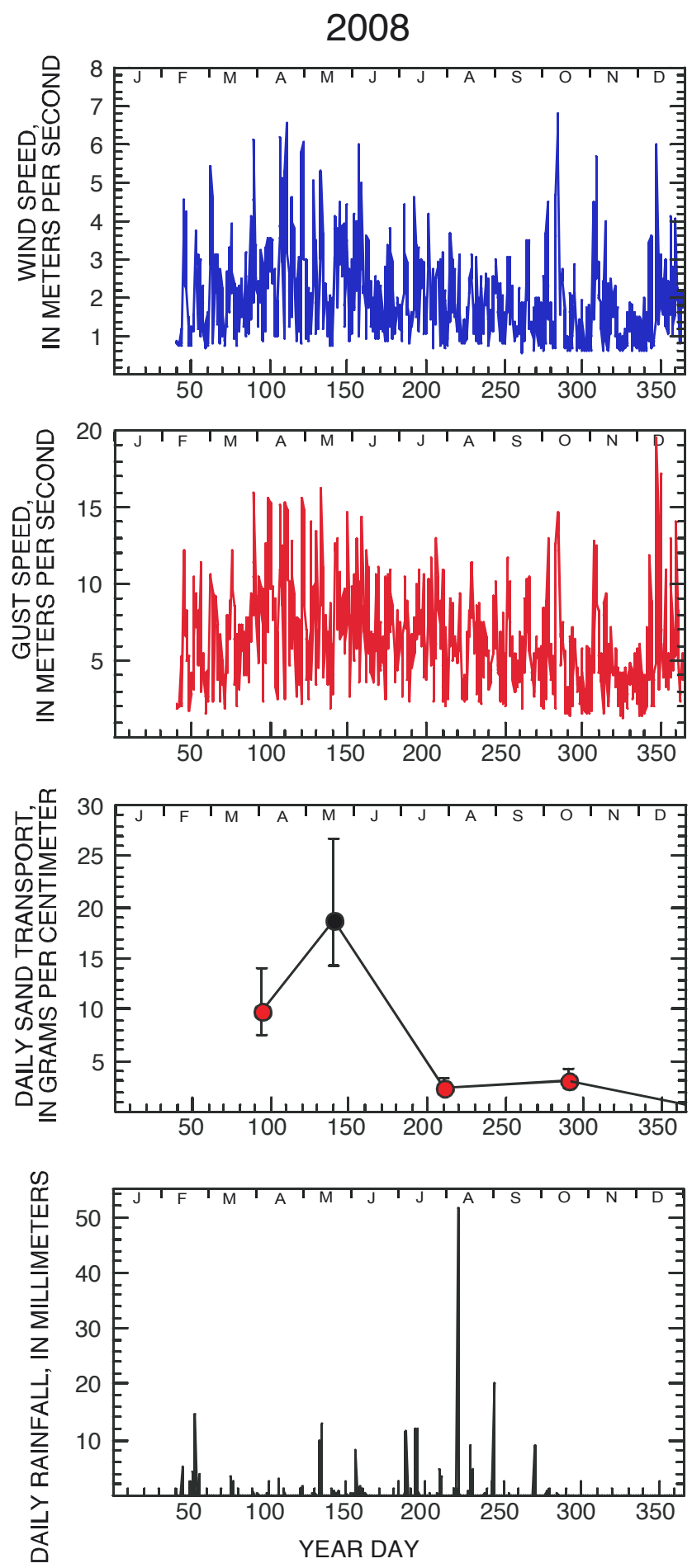

Figure 26. Wind, aeolian sand-transport, and rainfall data collected at the instrument station AZ C:13:0365 U in the Colorado River corridor, Grand Canyon, Ariz., in 2007 and 2008. Daily sand transport is plotted in grams, normalized to a width of $1 \mathrm{~cm}$. To obtain these values, total sand mass collected from four traps during each maintenance visit was divided by number of days since traps had last been emptied. Red circles on the sand-transport plot indicate minimum estimates only; these were made from data when the sand traps were found to have been blown over by the wind. Wind speed (blue plot) is presented as diurnal average values, using daytime (0600$1800 \mathrm{~h}$ ) and nighttime (1800-0600 h) averages of data collected at 4-minute intervals. Gust speed (red plot) is shown as maximum values that occurred during each diurnal interval. Rainfall is plotted as daily (24-hour) totals. Months are shown as single letter abbreviations at top of figure. 

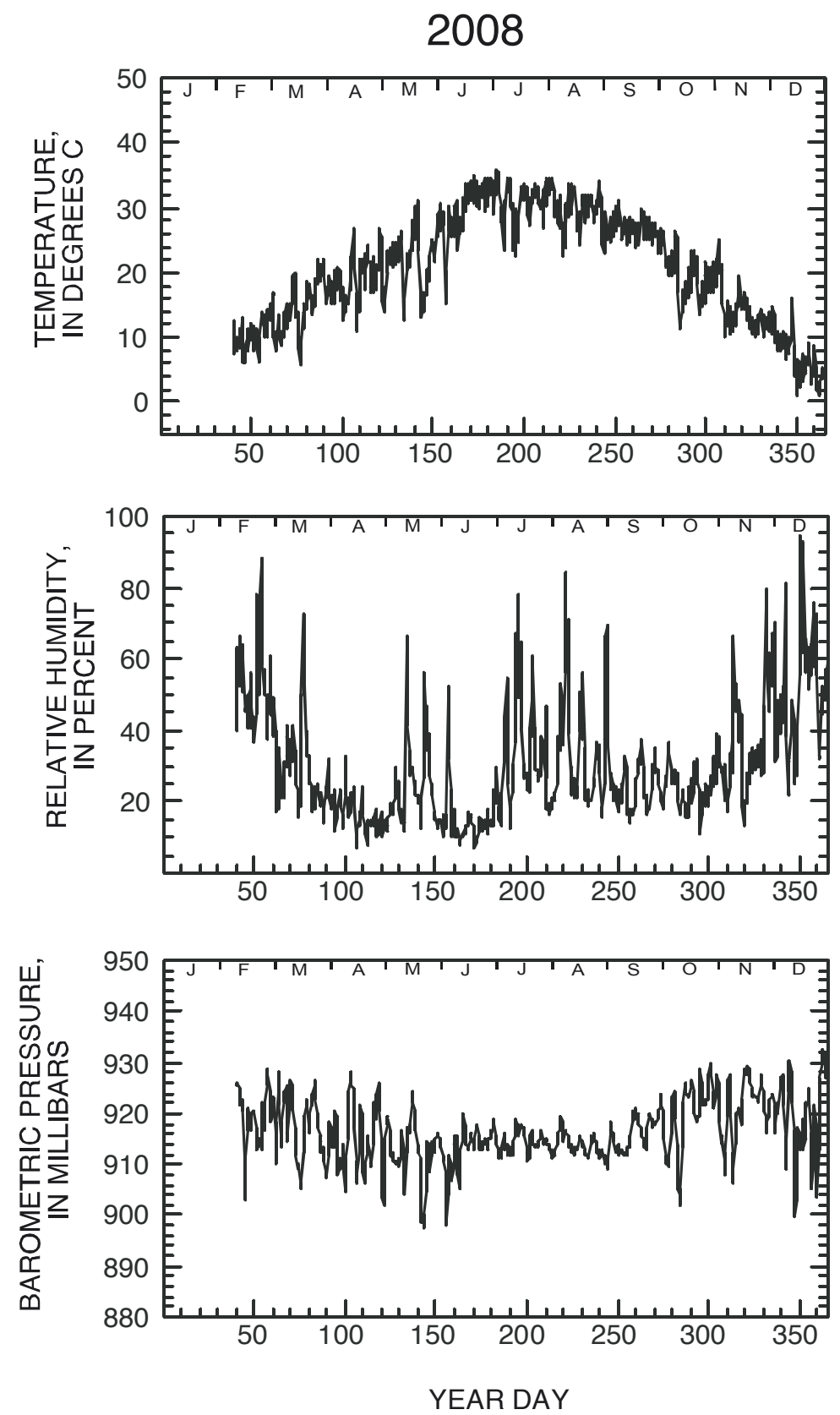

Figure 27. Temperature, humidity, and barometric pressure data collected at the instrument station AZ C:13:0365 L in the Colorado River corridor, Grand Canyon, Ariz., in 2007 and 2008. All parameters are plotted as diurnal averages (defined using 0600-1800 and 1800-0600 hours). Months are shown as single letter abbreviations at top of figure. 


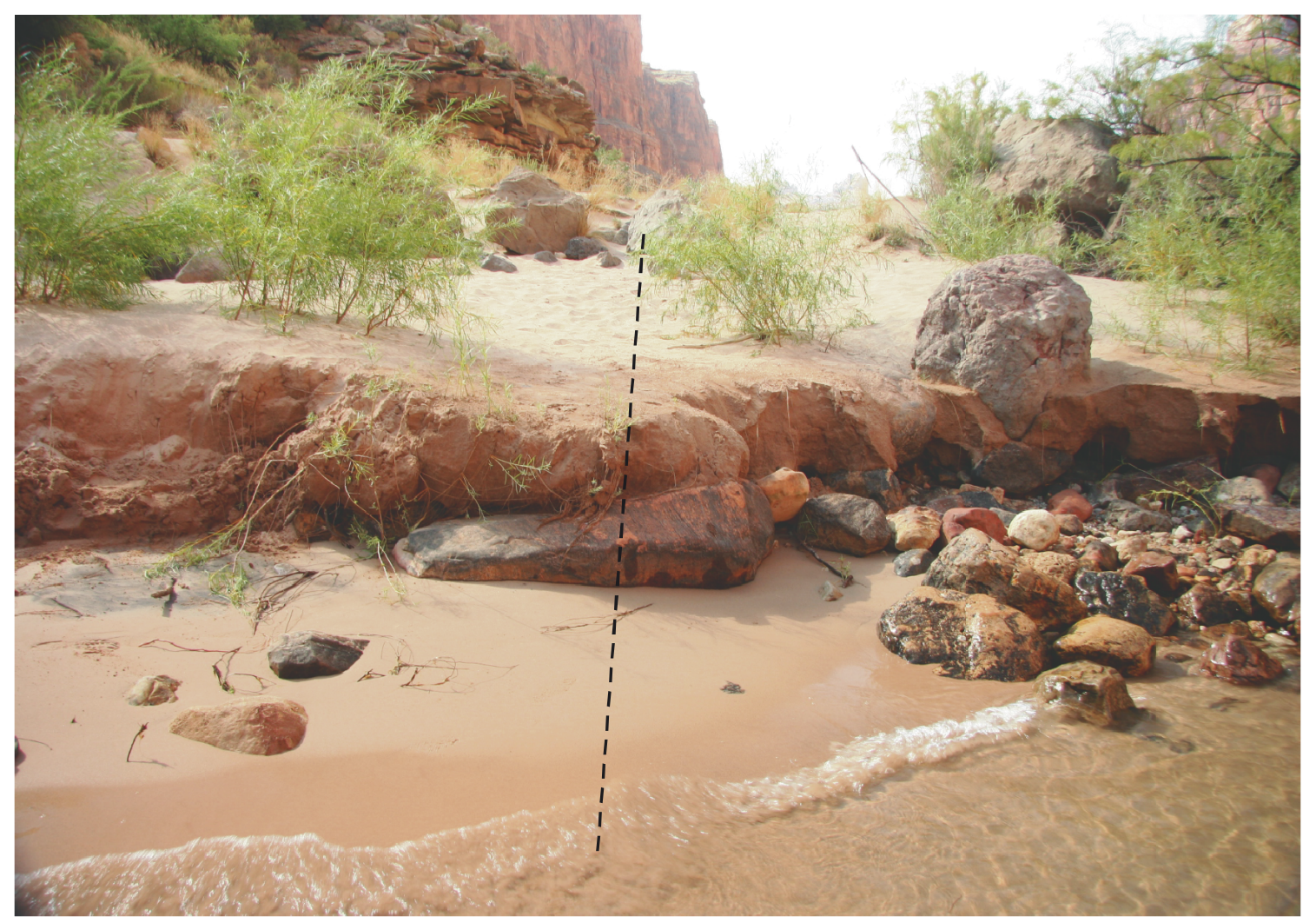

Figure 28. Photograph of the sandbar near AZ C:13:0006 after the 2008 high-flow experiment (HFE). This photograph, taken on July 28,2008 , at a discharge of approximately $340 \mathrm{~m}^{3} / \mathrm{s}\left(12,000 \mathrm{ft}^{3} / \mathrm{s}\right)$ shows sand deposited by the HFE (burying willow saplings) that was subsequently eroded by fluctuating flows. The dashed line indicates the location of the shore-perpendicular topographic profiles in figure 29. (USGS photograph by Amy Draut.) 


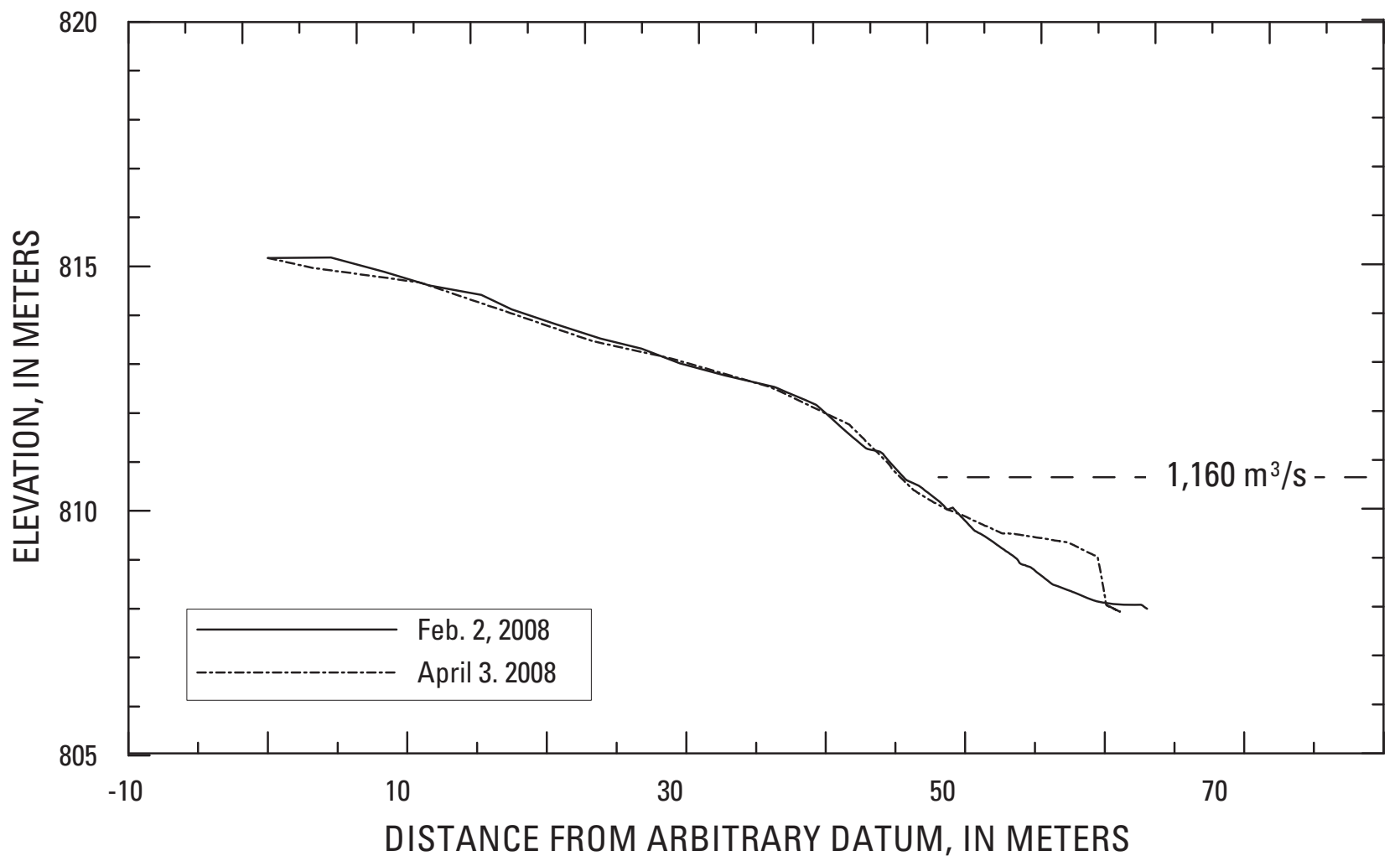

Figure 29. Surveyed shore-perpendicular profiles of the sandbar near AZ C:13:0006 before and after the 2008 high-flow experiment (HFE). The elevation of the HFE peak stage is indicated $\left(1,160 \mathrm{~m}^{3} / \mathrm{s}\right)$. Profiles trend due north, approximately perpendicular to the channel margin. 


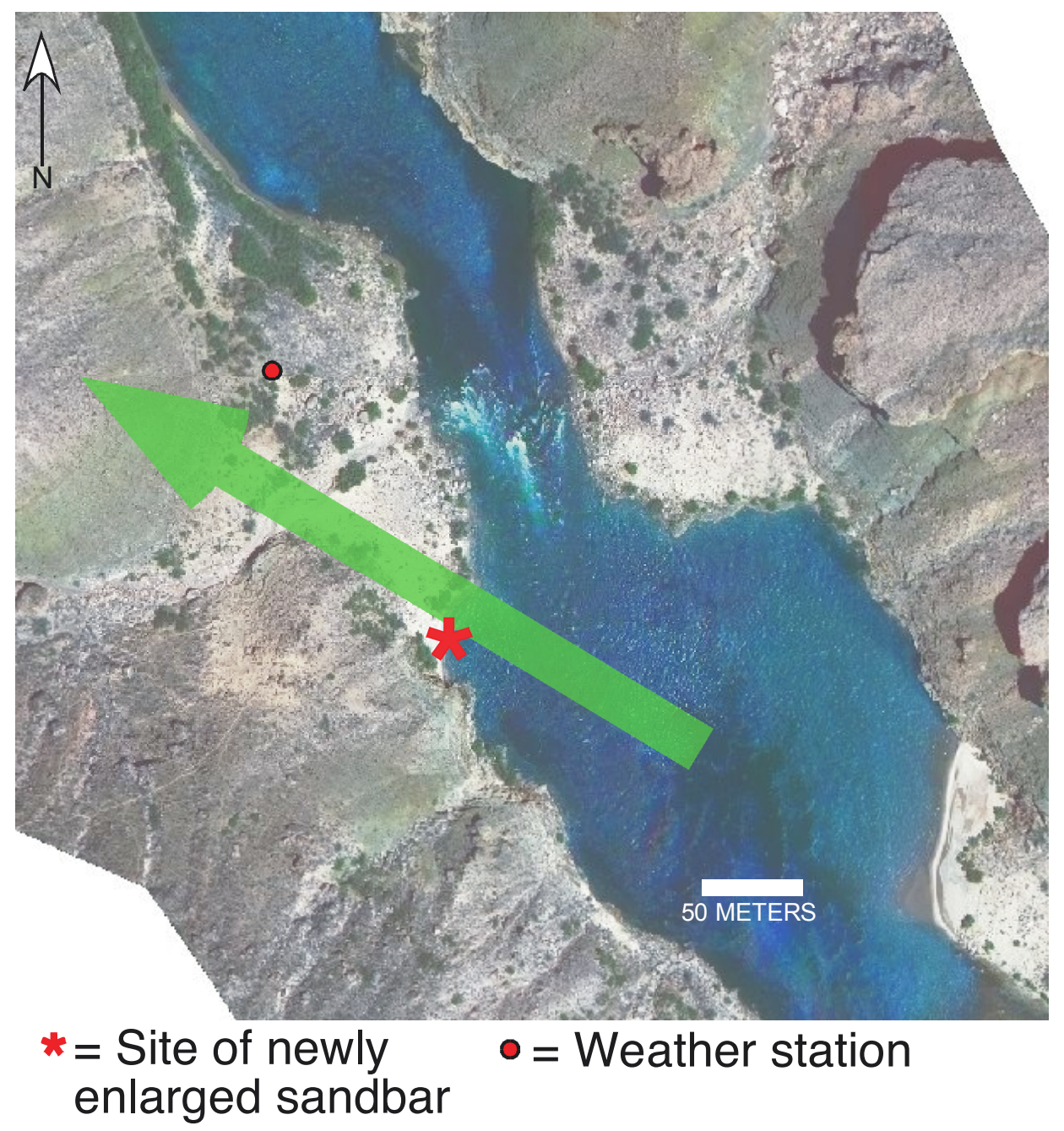

Figure 30. Aerial photograph of the area around AZ C:13:0006, in Grand Canyon, Ariz., with arrow indicating net direction of potential aeolian sediment transport measured in 2008. A vector sum of the $Q p$ proxy variable (equation 1), calculated using all available wind data from AZ C:13:0006 in 2008 (excluding data from March-0ctober, when the wind sensor was not operating correctly), indicates net sediment transport from 115 degrees. (USGS photograph.) 


\section{4-MINUTE AVERAGE WIND SPEED, IN METERS PER SECOND \\ AND WIND DIRECTION, IN DEGREES}

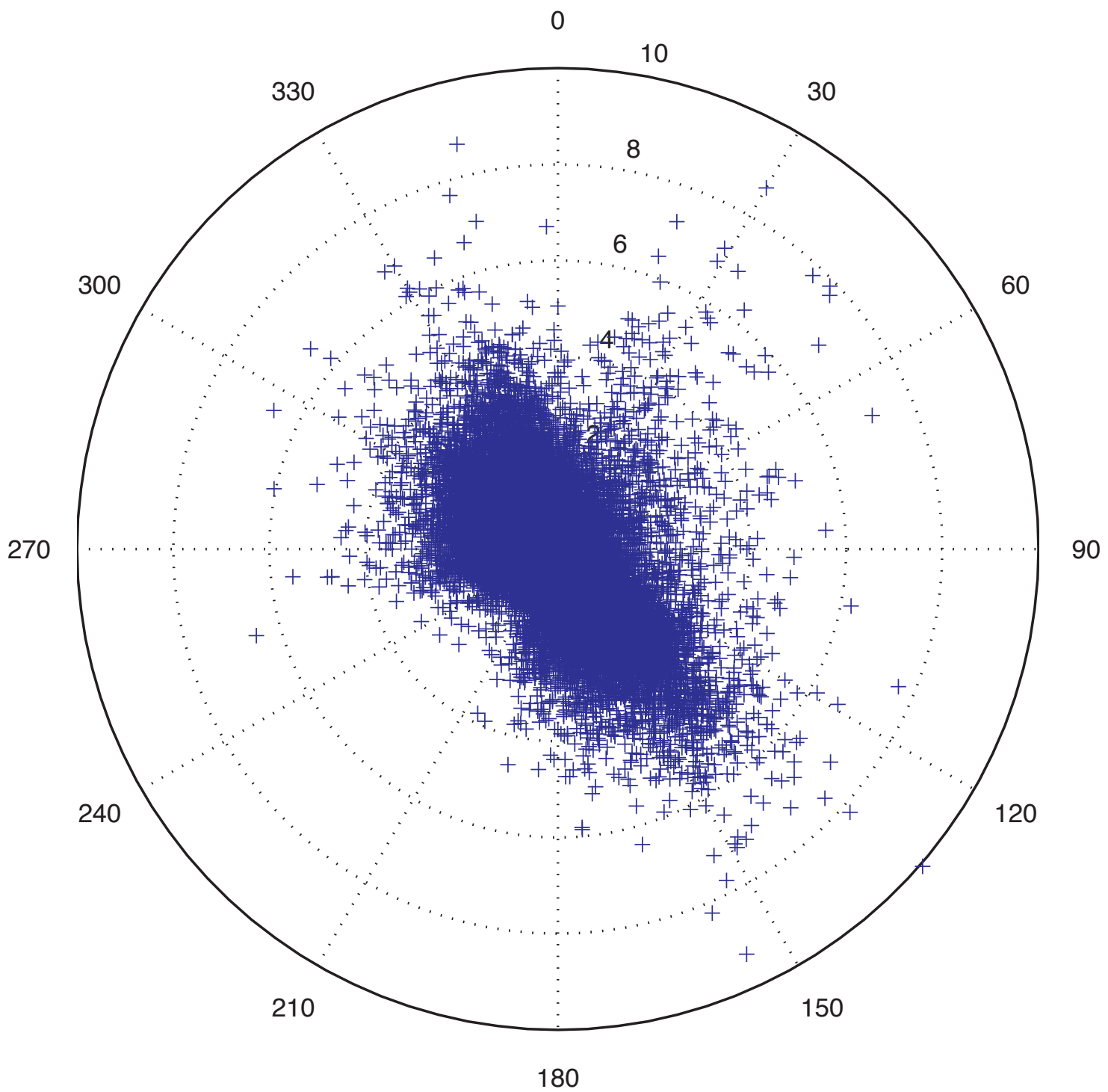

Figure 31. Magnitude and direction of wind velocity measured at the instrument station AZ C:13:0006 in the Colorado River corridor, Grand Canyon, Ariz., at 4-minute resolution in 2008. Magnitude is indicated by the concentric circles, and compass bearing indicates direction from which the wind came. This plot excludes data collected between March and October, when the wind sensor at this station was not operating correctly. 


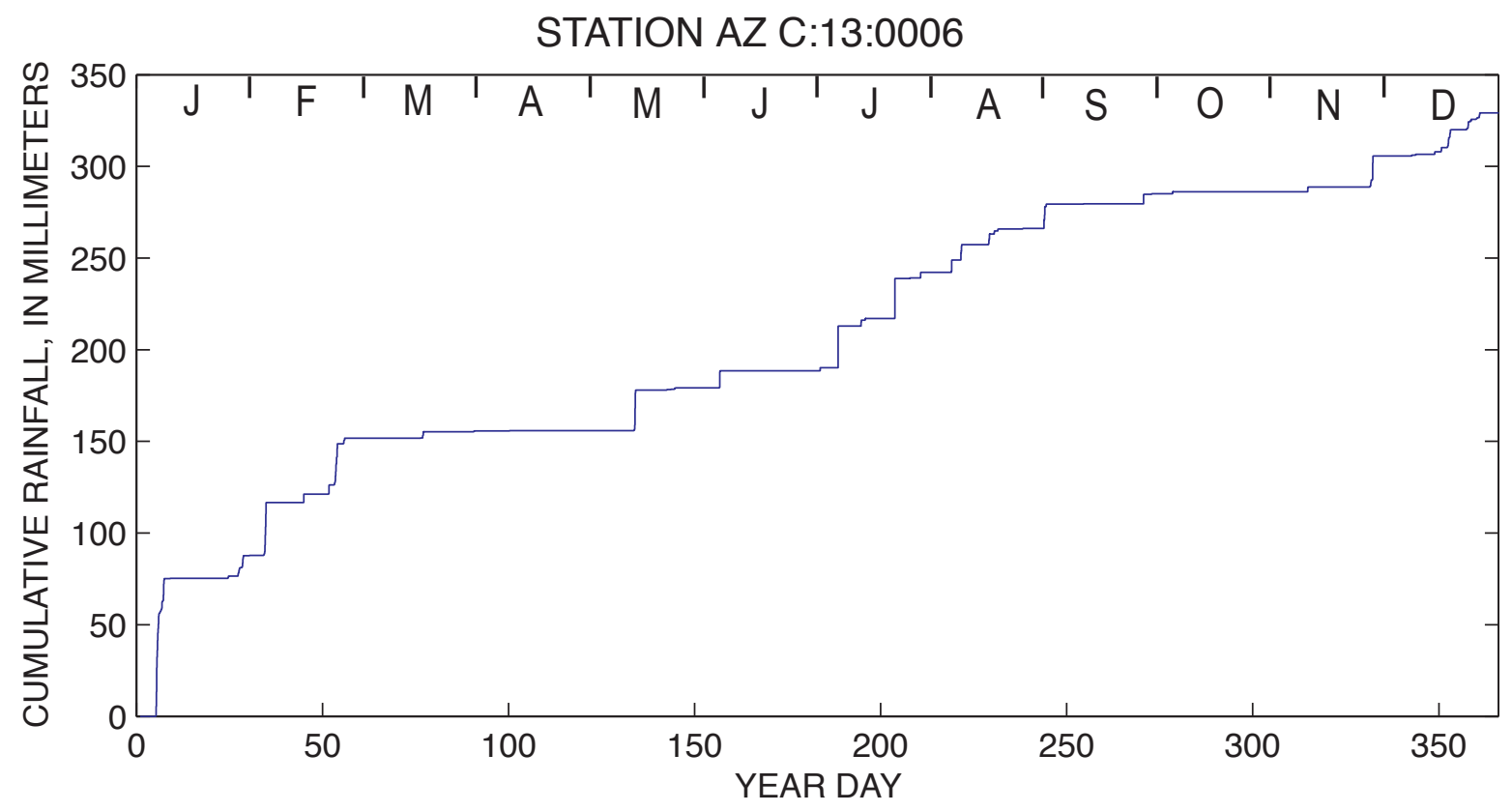

Figure 32. Cumulative 2008 rainfall record measured at AZ C:13:0006 in the Colorado River corridor, Grand Canyon, Ariz., compiled from data collected at 4-minute resolution. Months are shown as single letter abbreviations at top of figure. 

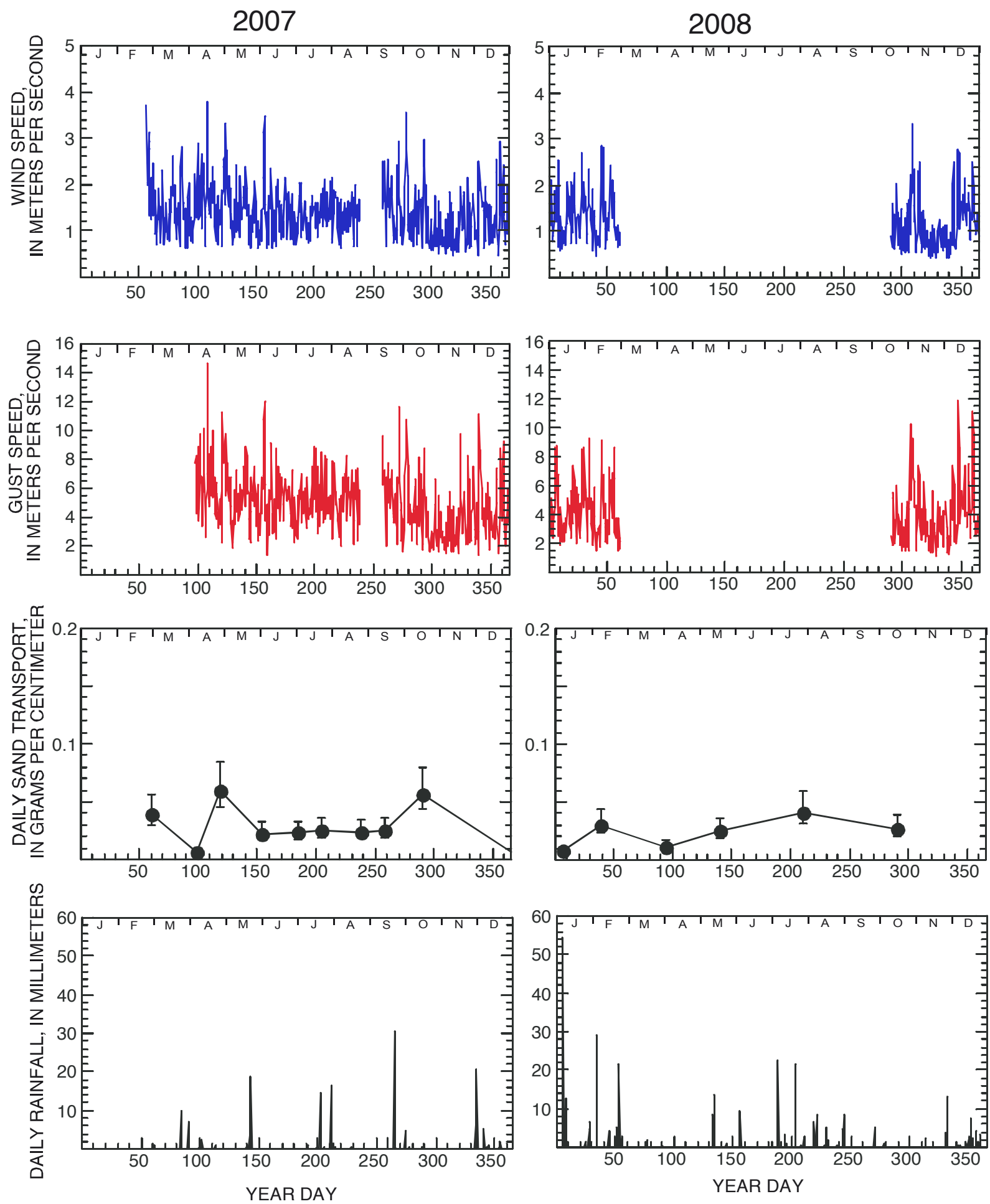

Figure 33. Wind, aeolian sand-transport, and rainfall data collected at the instrument station AZ C:13:0006 in the Colorado River corridor, Grand Canyon, Ariz., in 2007 and 2008. Daily sand transport is plotted in grams, normalized to a width of $1 \mathrm{~cm}$. To obtain these values, total sand mass collected from four traps during each maintenance visit was divided by number of days since traps had last been emptied. Wind speed (blue plot) is presented as diurnal average values, using daytime (0600-1800 h) and nighttime (1800-0600 h) averages of data collected at 4-minute intervals. Gust speed (red plot) is shown as maximum values that occurred during each diurnal interval. Wind and gust speed plots exclude data between March and October 2008, when the wind sensor at this station was not operating correctly. Rainfall is plotted as daily (24-hour) totals. Months are shown as single letter abbreviations at top of figure. 

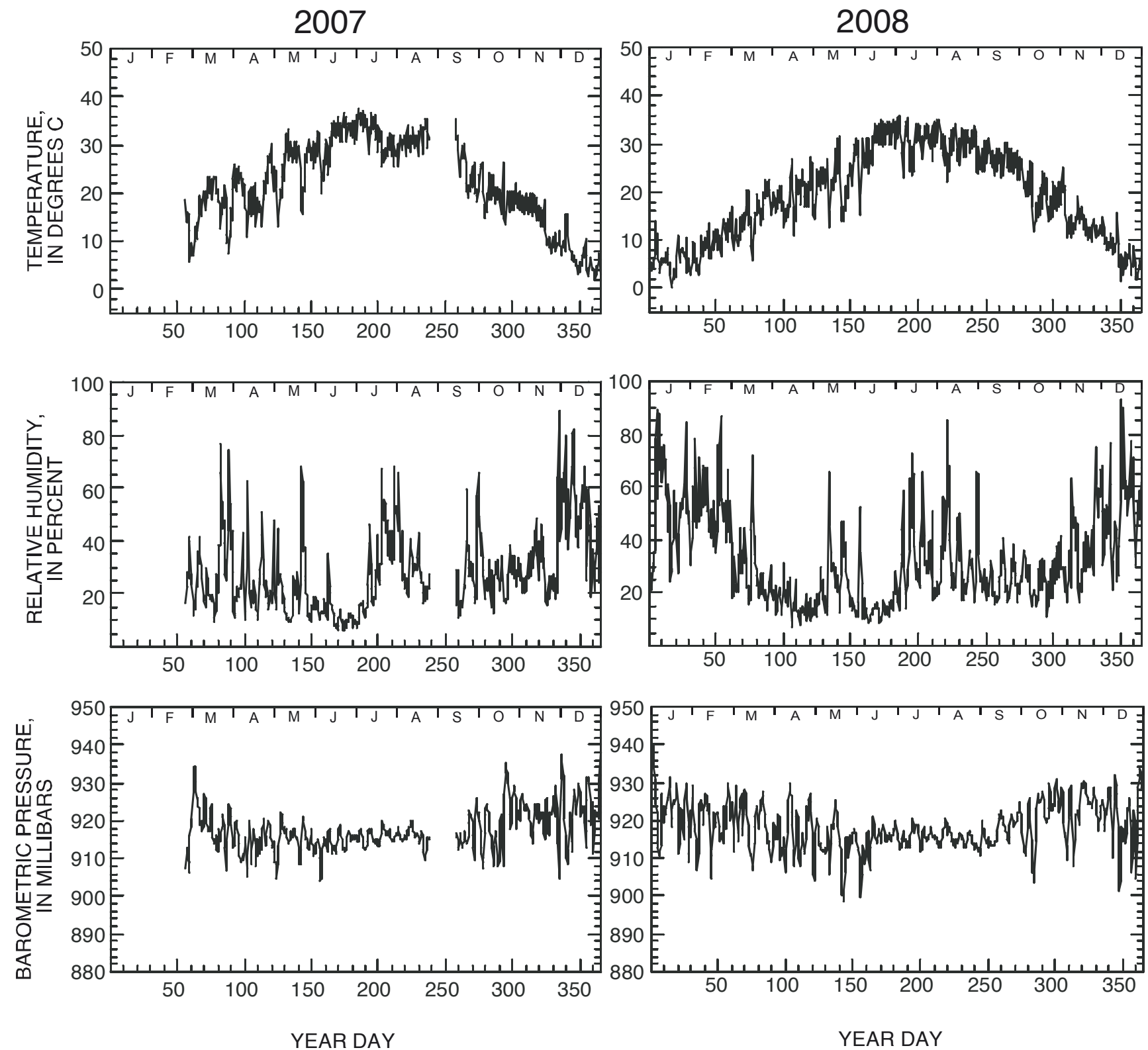

Figure 34. Temperature, humidity, and barometric pressure data collected at the instrument station AZ C:13:0006 in the Colorado River corridor, Grand Canyon, Ariz., in 2007 and 2008. All parameters are plotted as diurnal averages (defined using 0600-1800 and 1800-0600 hours). Months are shown as single letter abbreviations at top of figure. 

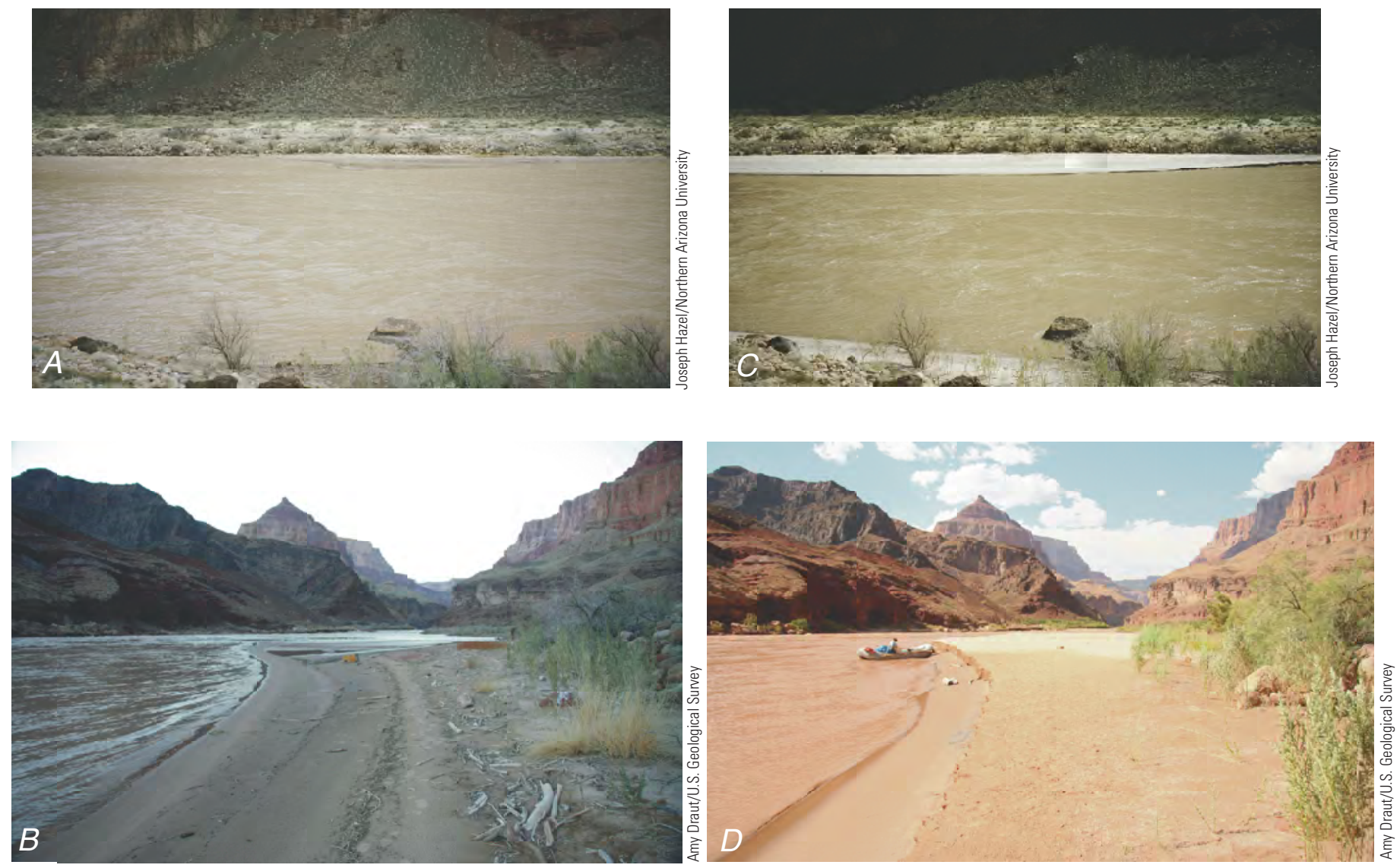

Figure 35. Photographs of the sandbar near AZ C:13:0336 before and after the 2008 high-flow experiment (HFE). A, Photograph taken from across the river on February 24, 2008, before the HFE. $B$, Photograph taken from the edge of the river on the same side as the sandbar on February 10, 2008, before the HFE. C, Photograph taken from across the river on March 10, 2008, one day after the HFE water receded. $D$, Photograph taken from the edge of the river on the same side as the sandbar on July 29, 2008. (USGS photographs by Amy Draut.) 


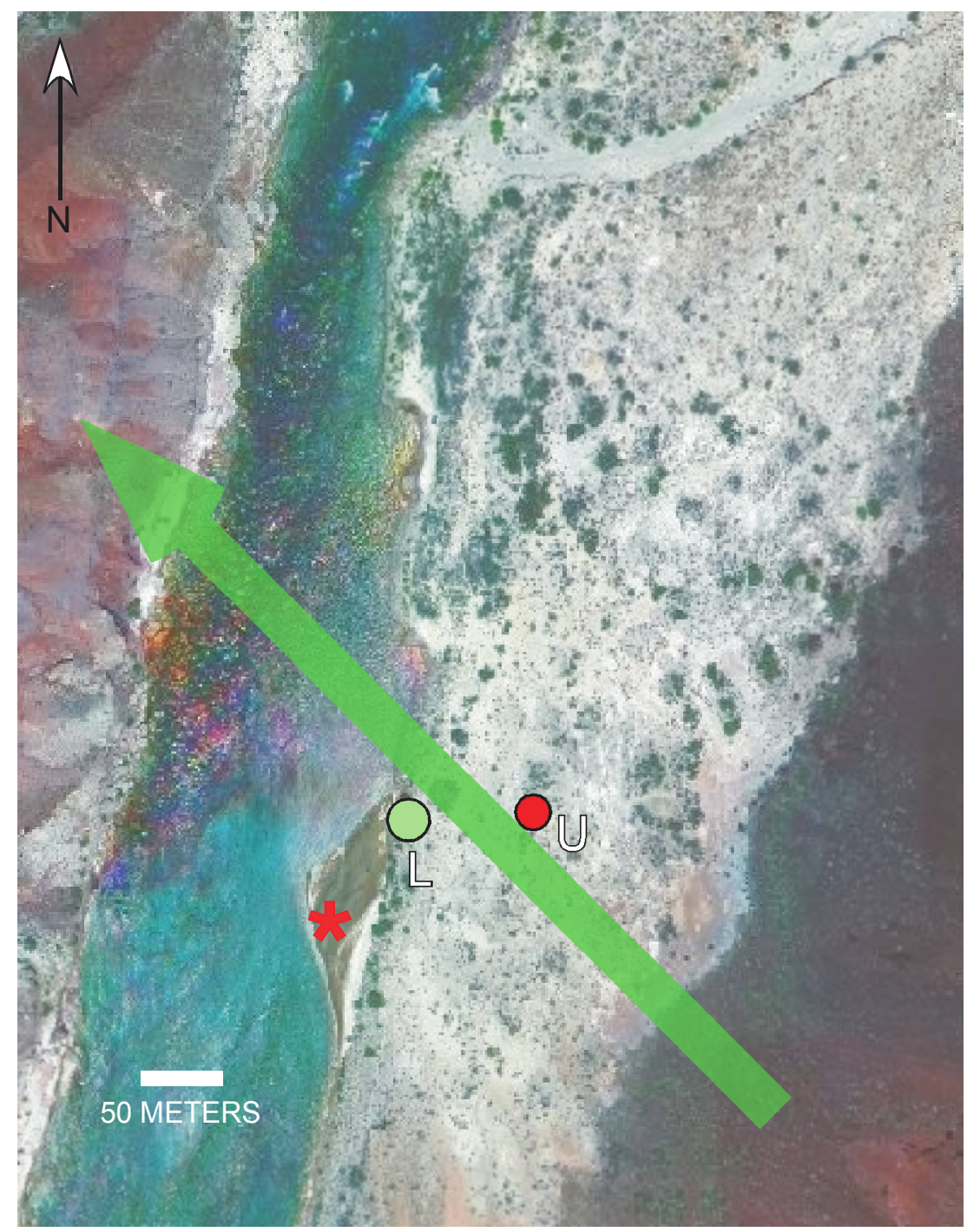

\section{* = Site of newly enlarged sandbar \\ $\mathrm{O}=$ Weather station $\mathrm{O}=$ Sand traps only}

Figure 36. Aerial photograph of the area around AZ C:13:0336, in Grand Canyon, Ariz., with arrow indicating net direction of potential aeolian sediment transport measured at $A Z \mathrm{C}: 13: 0336 \mathrm{U}$ in 2008. A vector sum of the Op proxy variable (equation 1), calculated using all available wind data from AZ C:13:0336 U in 2008, indicates net sediment transport from 133 degrees. (USGS photograph.) 


\section{4-MINUTE AVERAGE WIND SPEED, IN METERS PER SECOND AND WIND DIRECTION, IN DEGREES}

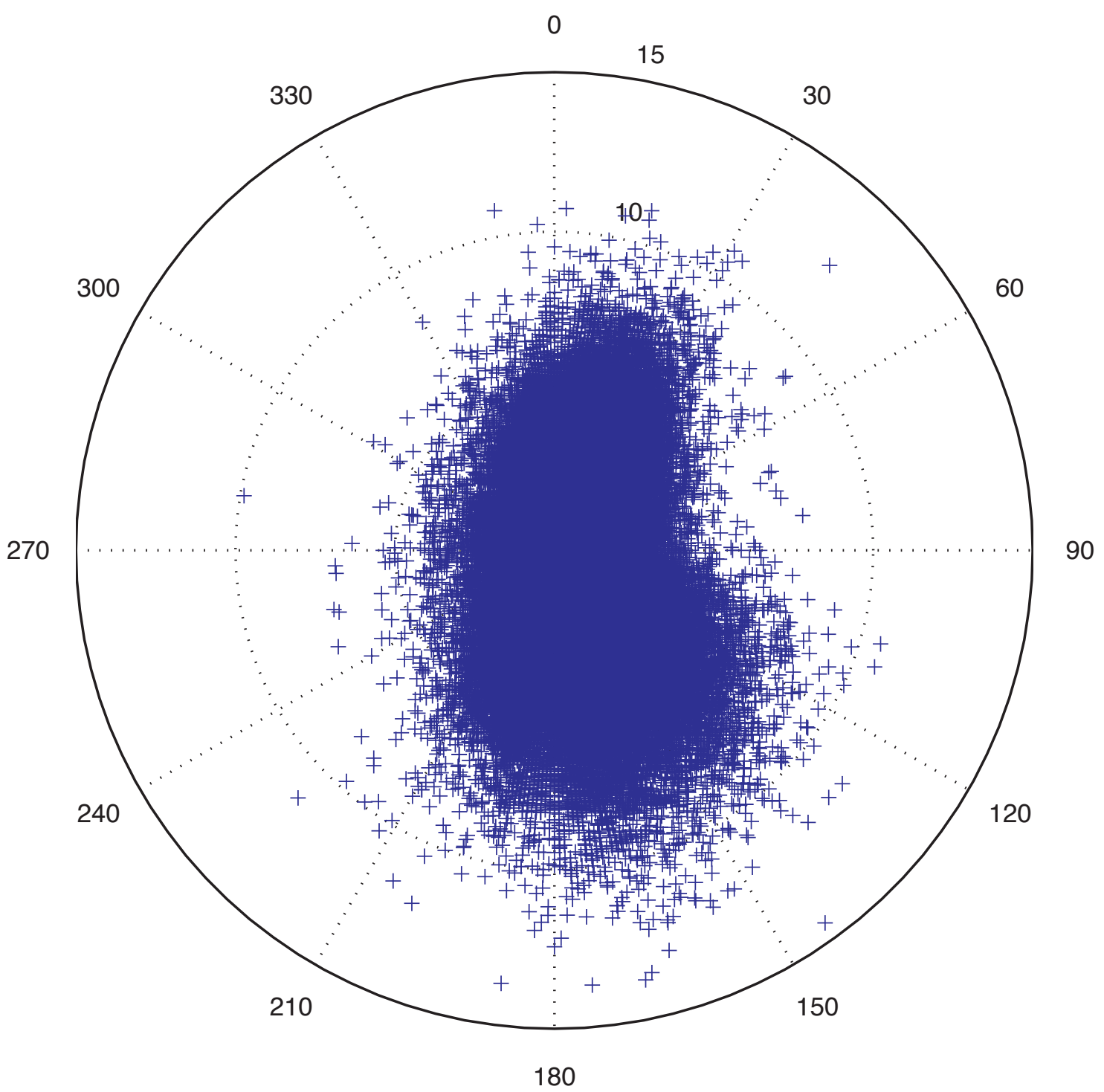

Figure 37. Magnitude and direction of wind velocity measured at the instrument station AZ C:13:0336 U in the Colorado River corridor, Grand Canyon, Ariz., at 4-minute resolution throughout 2008. Magnitude is indicated by the concentric circles, and compass bearing indicates direction from which the wind came. 


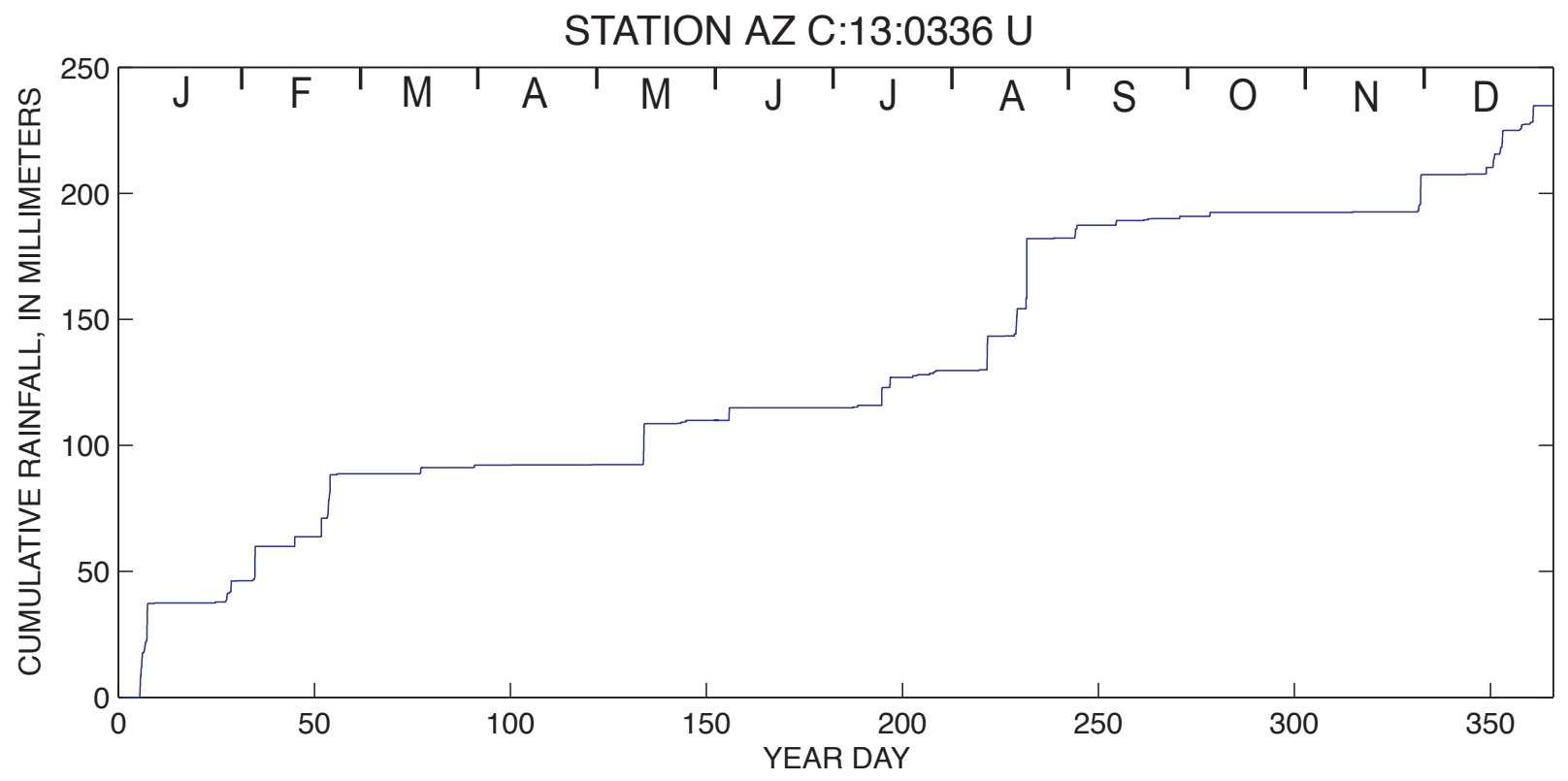

Figure 38. Cumulative 2008 rainfall record measured at AZ C:13:0336 U, compiled from data collected at 4-minute resolution. Months are shown as single letter abbreviations at top of figure. 

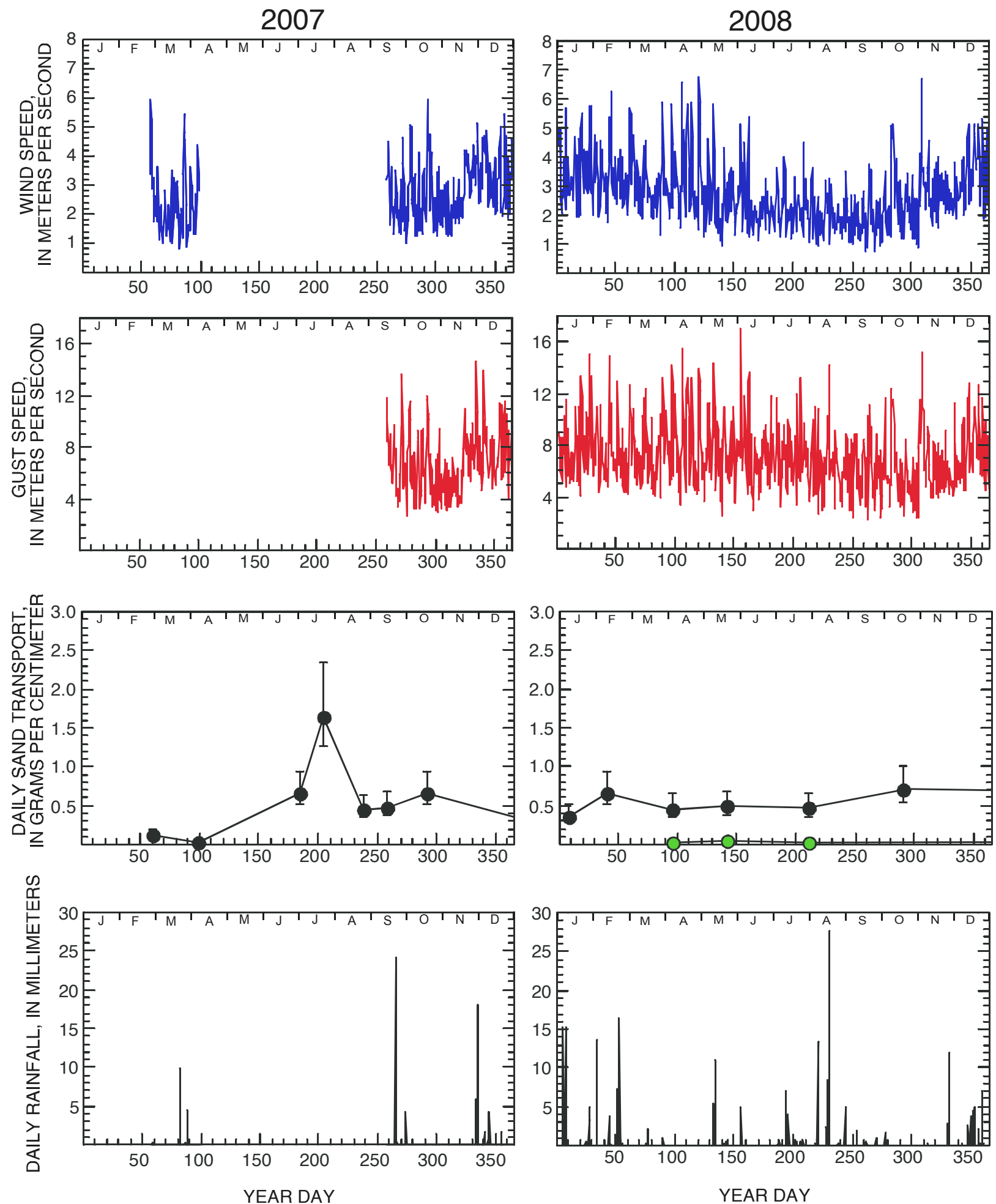

Figure 39. Wind, aeolian sand-transport, and rainfall data collected at the instrument station AZ C:13:0336 U in the Colorado River corridor, Grand Canyon, Ariz., in 2007 and 2008, and sand-transport data collected at AZ C:13:0336 L (green circles) in 2008. Daily sand transport is plotted in grams, normalized to a width of $1 \mathrm{~cm}$. To obtain these values, total sand mass collected from four traps during each maintenance visit was divided by number of days since traps had last been emptied. Wind speed (blue plot) is presented as diurnal average values, using daytime (0600-1800 h) and nighttime (1800-0600 h) averages of data collected at 4-minute intervals. Gust speed (red plot) is shown as maximum values that occurred during each diurnal interval. Rainfall is plotted as daily (24-hour) totals. Months are shown as single letter abbreviations at top of figure. 

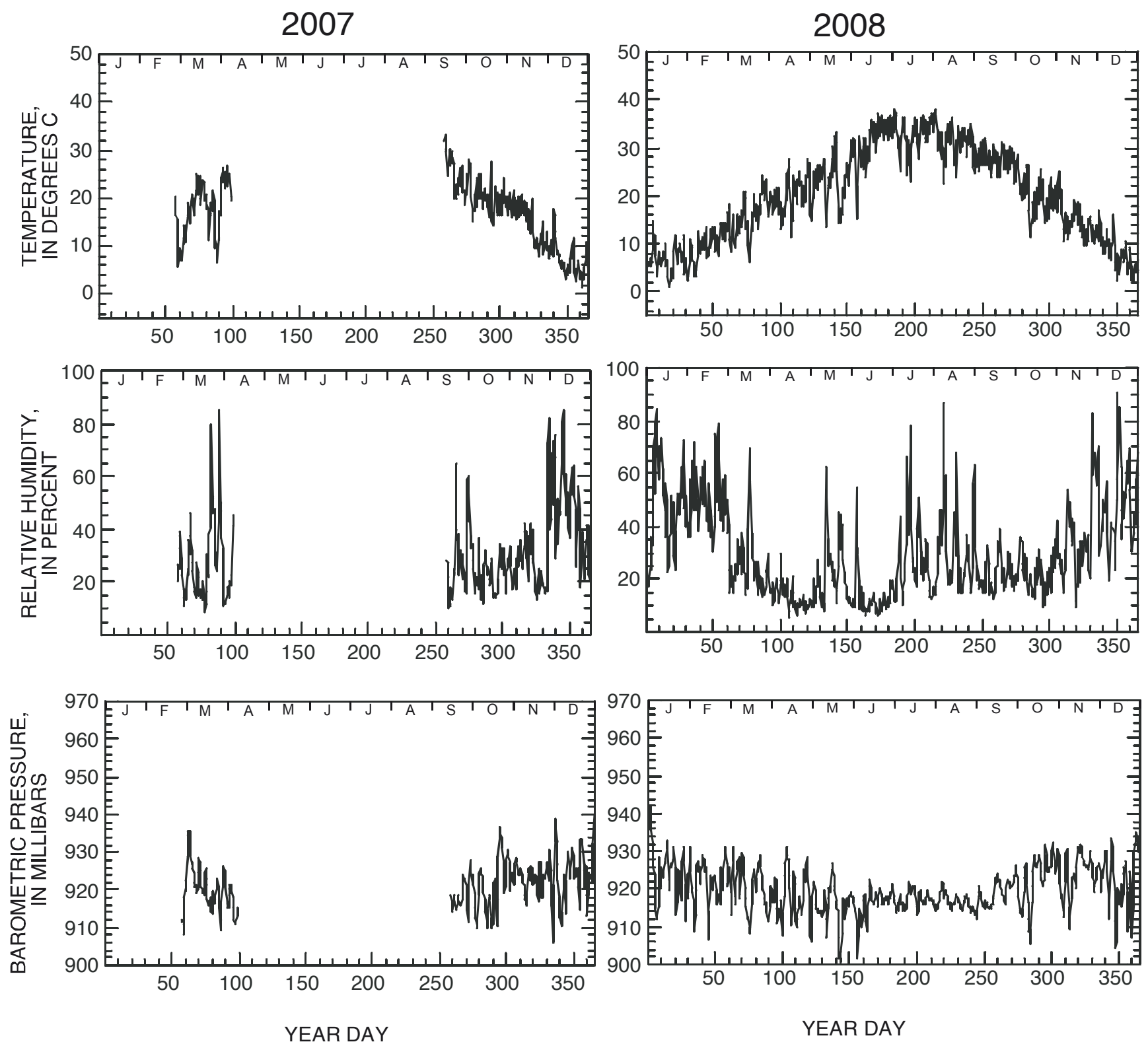

Figure 40. Temperature, humidity, and barometric pressure data collected at the instrument station AZ C:13:0336 U in the Colorado River corridor, Grand Canyon, Ariz., in 2007 and 2008. All parameters are plotted as diurnal averages (defined using 0600-1800 and 1800-0600 hours). Months are shown as single letter abbreviations at top of figure. 


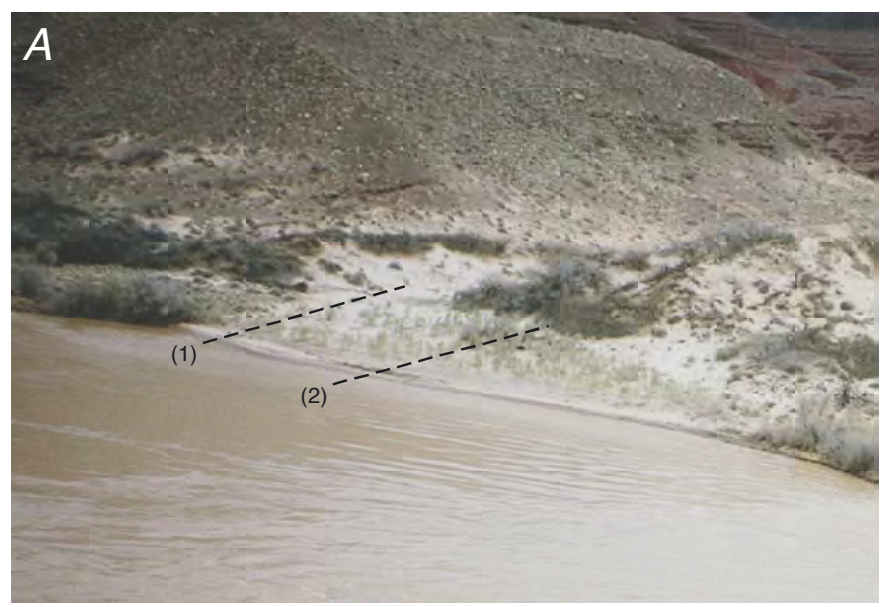

Joseph Hazel/Northern Arizona University

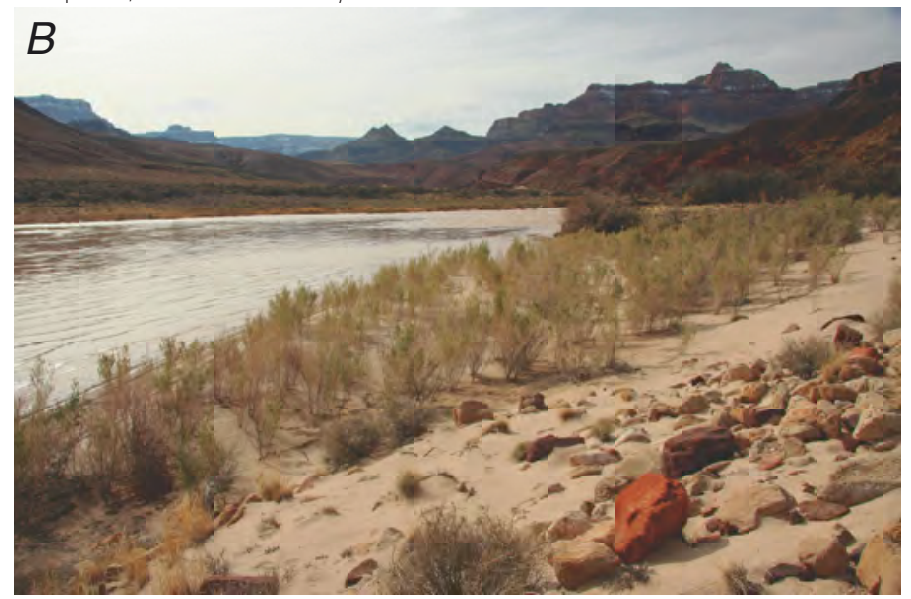

Amy Draut/U.S. Geological Survey

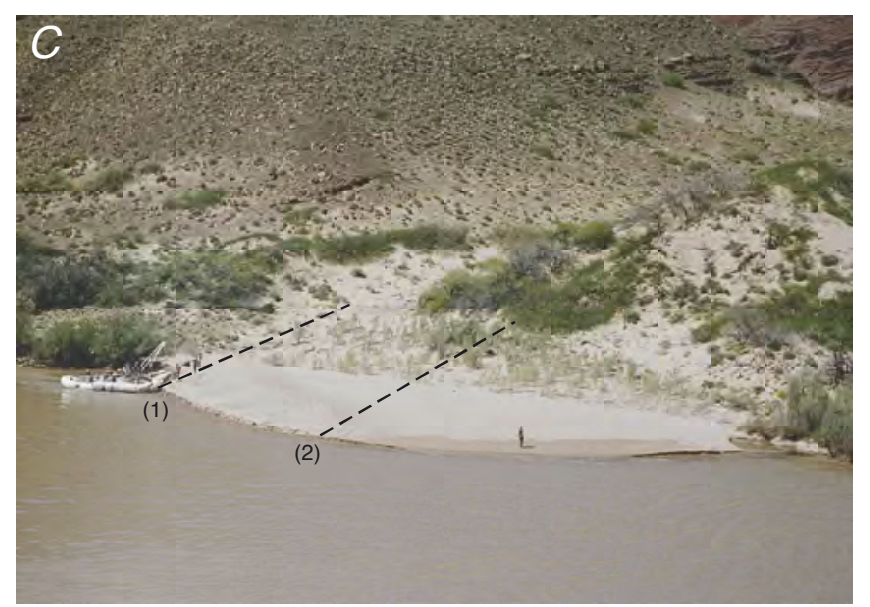

Joseph Hazel/Northern Arizona University

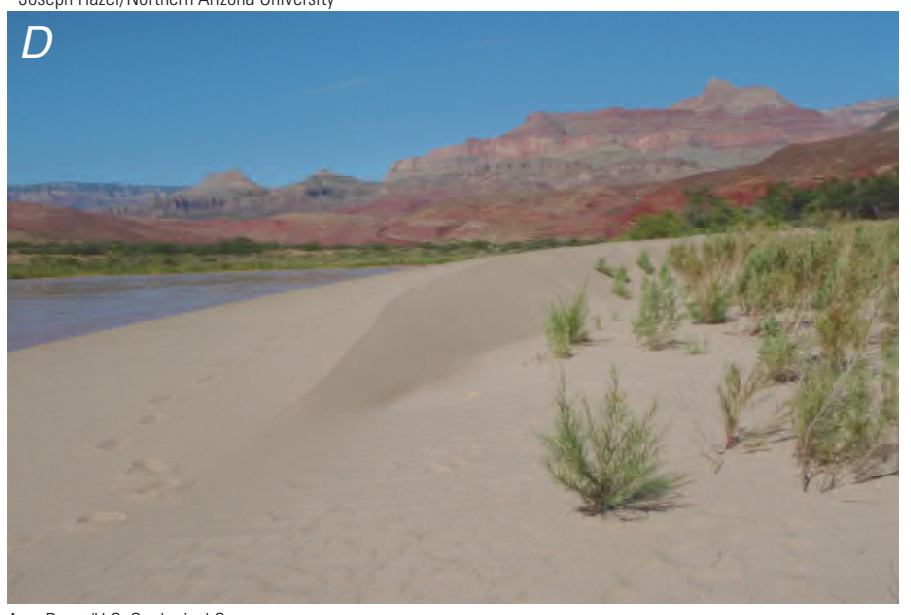

Amy Draut/U.S. Geological Survey

Figure 41. Photographs of the sandbar near AZ C:13:0321 before and after the 2008 high-flow experiment (HFE). A, Photograph taken from across the river on February 24, 2008, before the HFE. Inland of the river, aeolian dunes stand approximately $10 \mathrm{~m}$ high and are vegetated by mesquite and other plants. $B$, Photograph taken near the edge of the river on the same side as the sandbar, on February 10, 2008, before the HFE. C, Photograph taken from across the river on April 5, 2008, after the HFE; note the person for scale standing at right side of sandbar. $D$, Photograph taken from approximately the same location as in $B$ on July 29, 2008, showing the crest of a new aeolian dune that formed from wind reworking of HFE sand. The slipface orientation of the dune indicates the dune is migrating, and moving sand, inland toward the field of larger aeolian dunes. Dashed lines (1) and (2) indicate locations of shore-perpendicular transects (profile 1 and profile 2) that are shown on figure 42. (USGS photographs by Amy Draut.) 

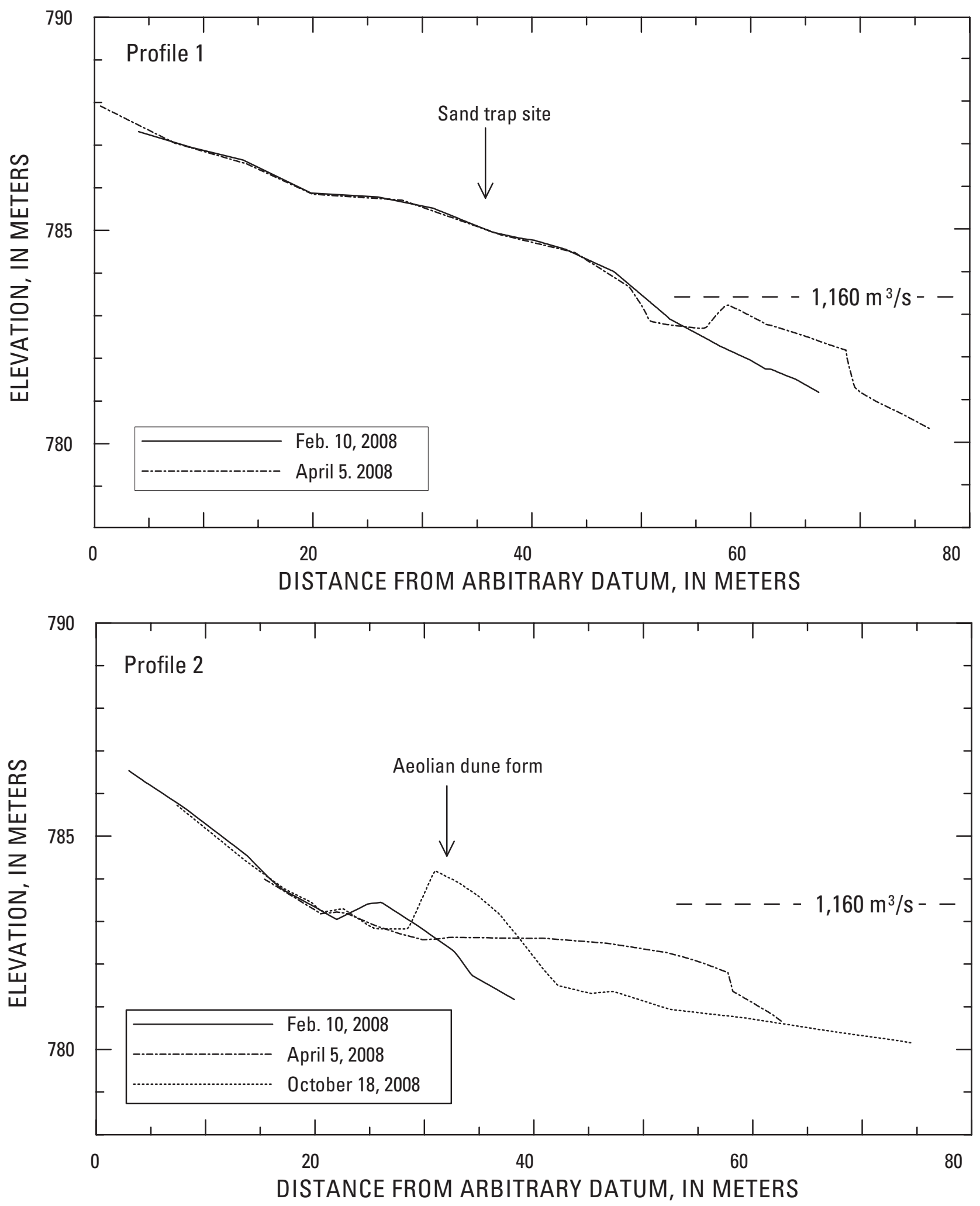

Figure 42. Surveyed shore-perpendicular profiles of the sandbar near AZ C:13:0321 before and after the 2008 high-flow experiment (HFE). The elevation of the HFE peak stage is indicated $\left(1,160 \mathrm{~m}^{3} / \mathrm{s}\right)$. Profiles trend approximately perpendicular to the channel margin; profile 1 trends northwest, profile 2 trends approximately due north. 


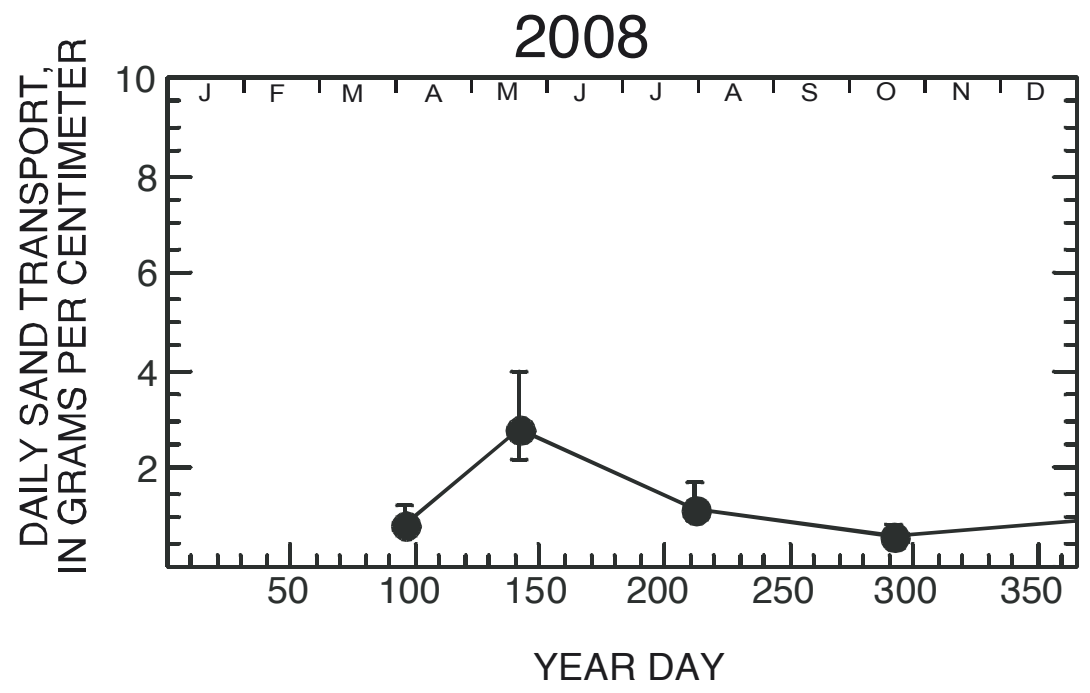

Figure 43. Aeolian sand-transport data collected near AZ C:13:0321 in 2008. Daily sand transport is plotted in grams, normalized to a width of $1 \mathrm{~cm}$. To obtain these values, total sand mass collected from four traps during each maintenance visit was divided by number of days since traps had last been emptied. Months are shown as single letter abbreviations at top of figure. 


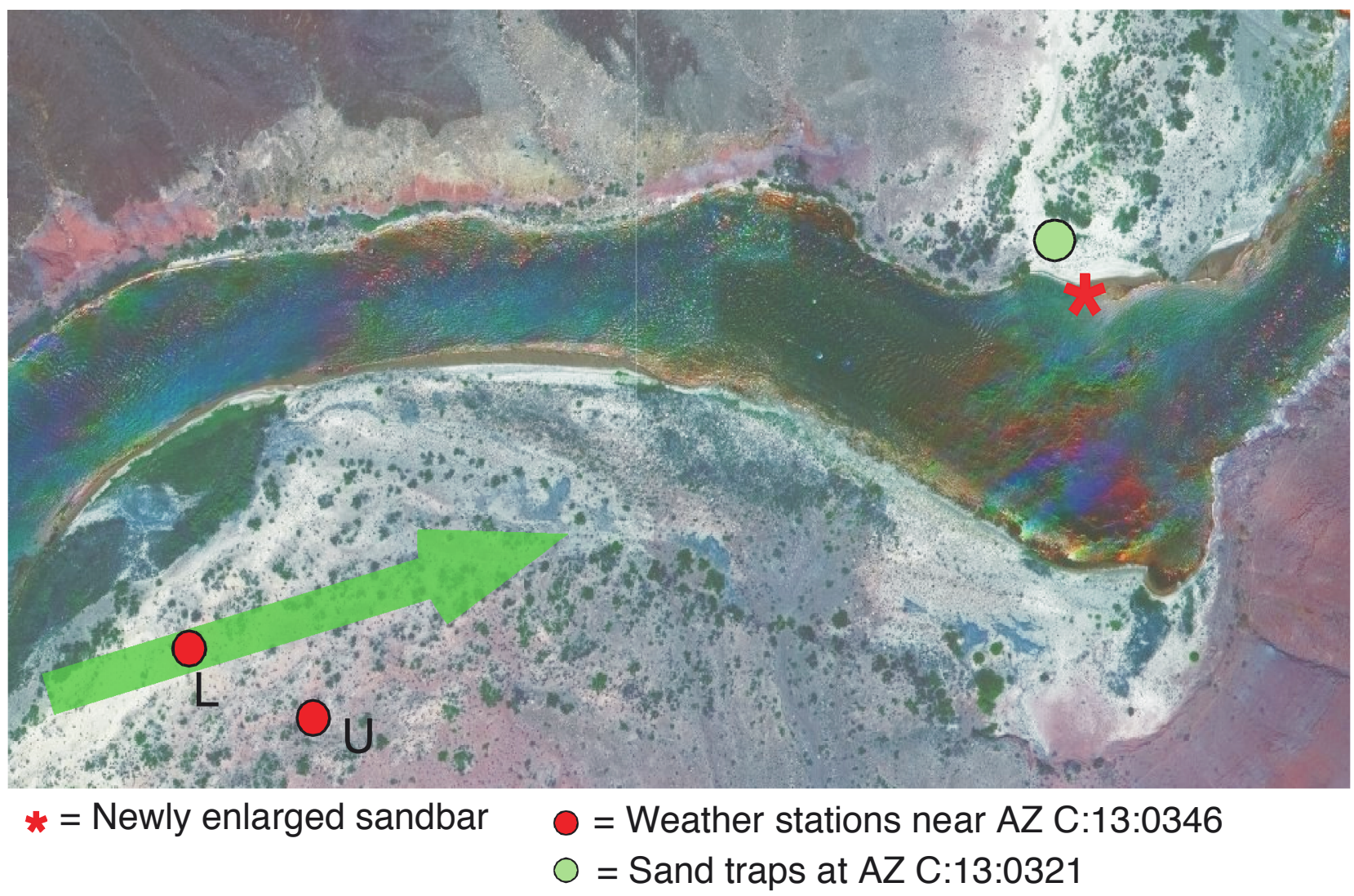

Figure 44. Aerial photograph of the area around AZ C:13:0346, in Grand Canyon, Ariz., with arrow indicating net direction of potential aeolian sediment transport measured at instrument station AZ C:13:0346 L in 2008. A vector sum of the $Q p$ proxy variable (equation 1), calculated using all available wind data from AZ C:13:0346 L in 2008, indicates net sediment transport from 252 degrees. (USGS photograph.) 


\section{4-MINUTE AVERAGE WIND SPEED, IN METERS PER SECOND AND WIND DIRECTION, IN DEGREES}

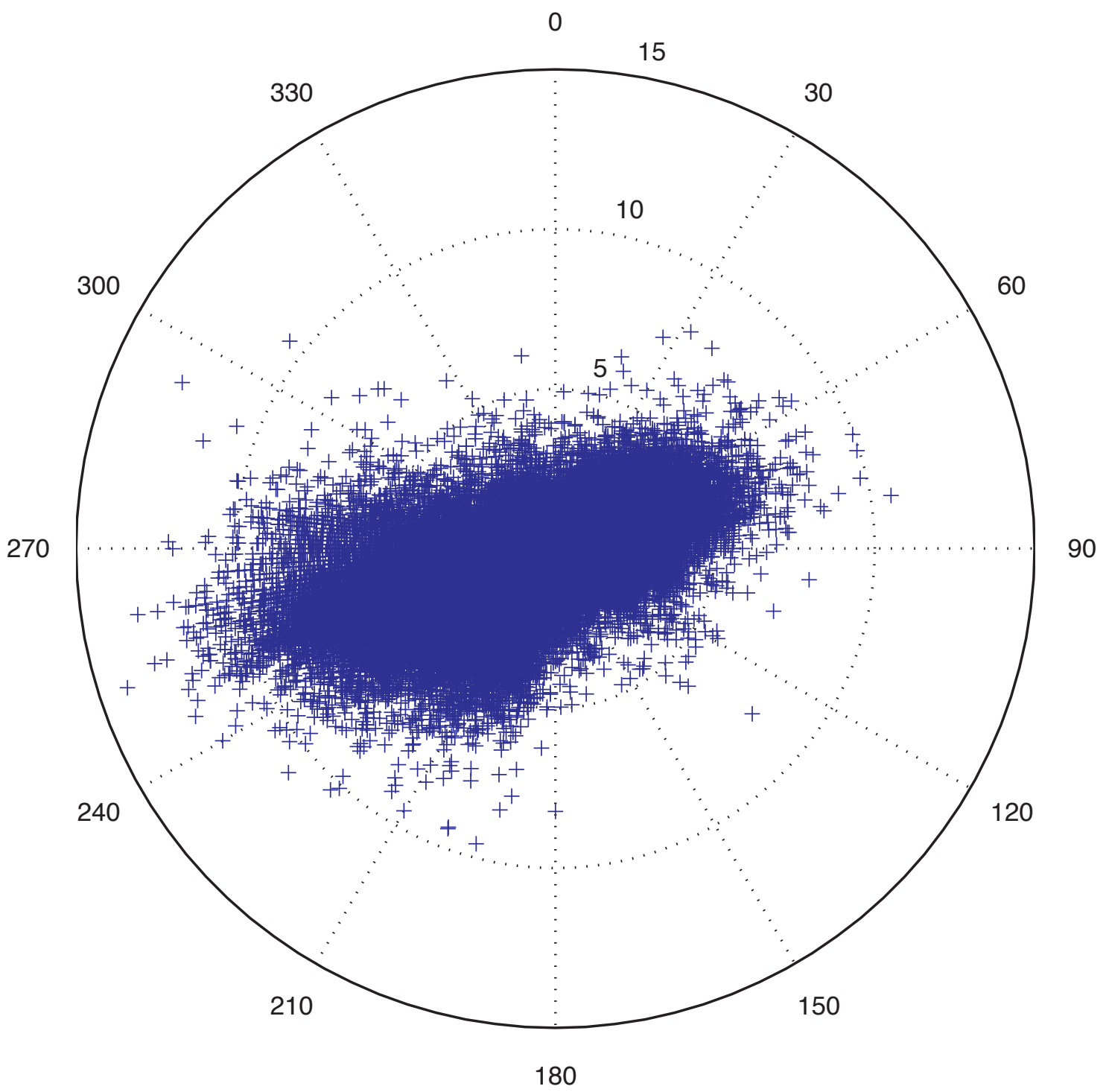

Figure 45. Magnitude and direction of wind velocity measured at the instrument station AZ C:13:0346 L in the Colorado River corridor, Grand Canyon, Ariz., at 4-minute resolution throughout 2008. Magnitude is indicated by the concentric circles, and compass bearing indicates direction from which the wind came. 
STATION AZ C:13:0346 L

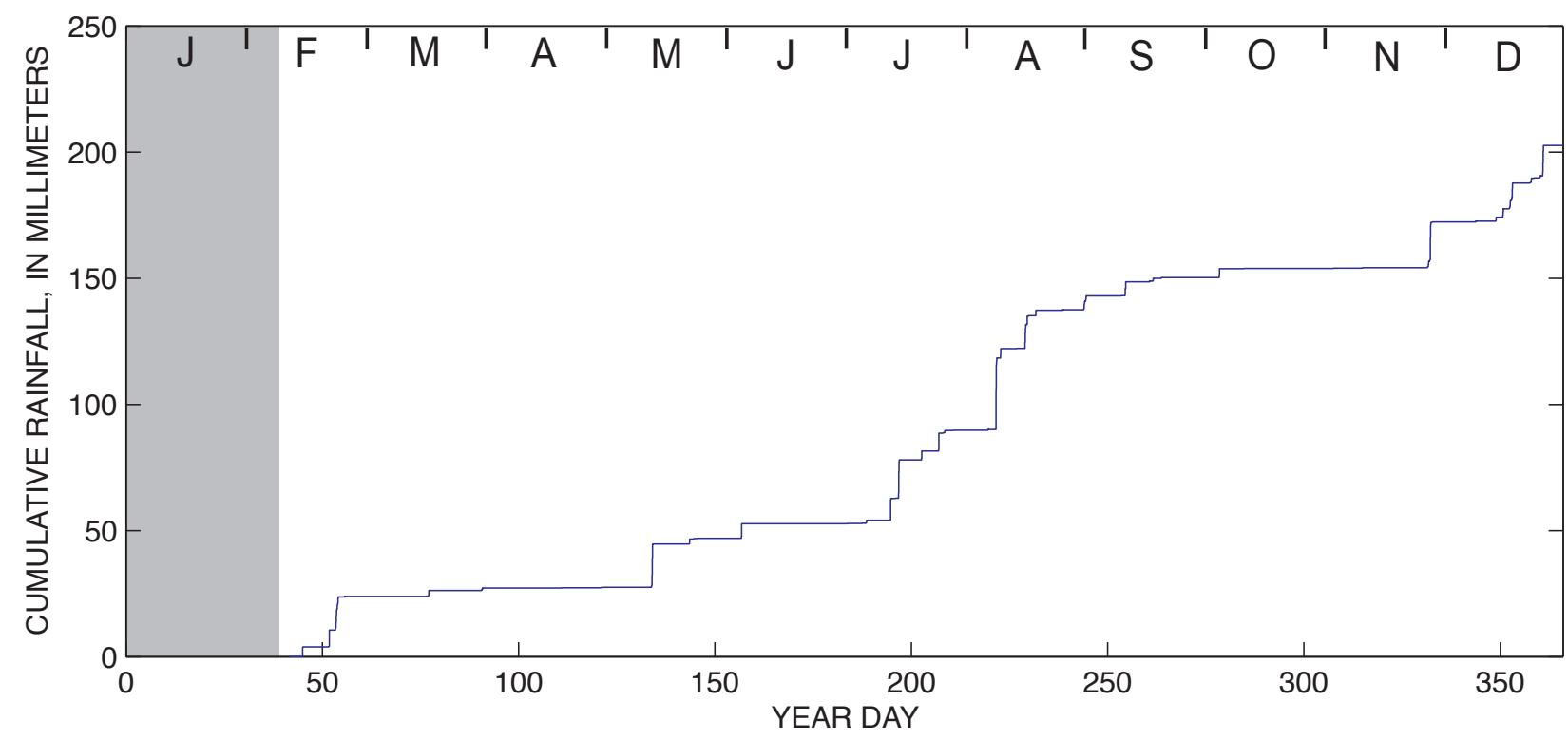

Figure 46. Cumulative 2008 rainfall record measured at AZ C:13:0346 L, compiled from data collected at 4-minute resolution. Gray shaded region indicates days when the station was not collecting data. Months are shown as single letter abbreviations at top of figure. 
2007
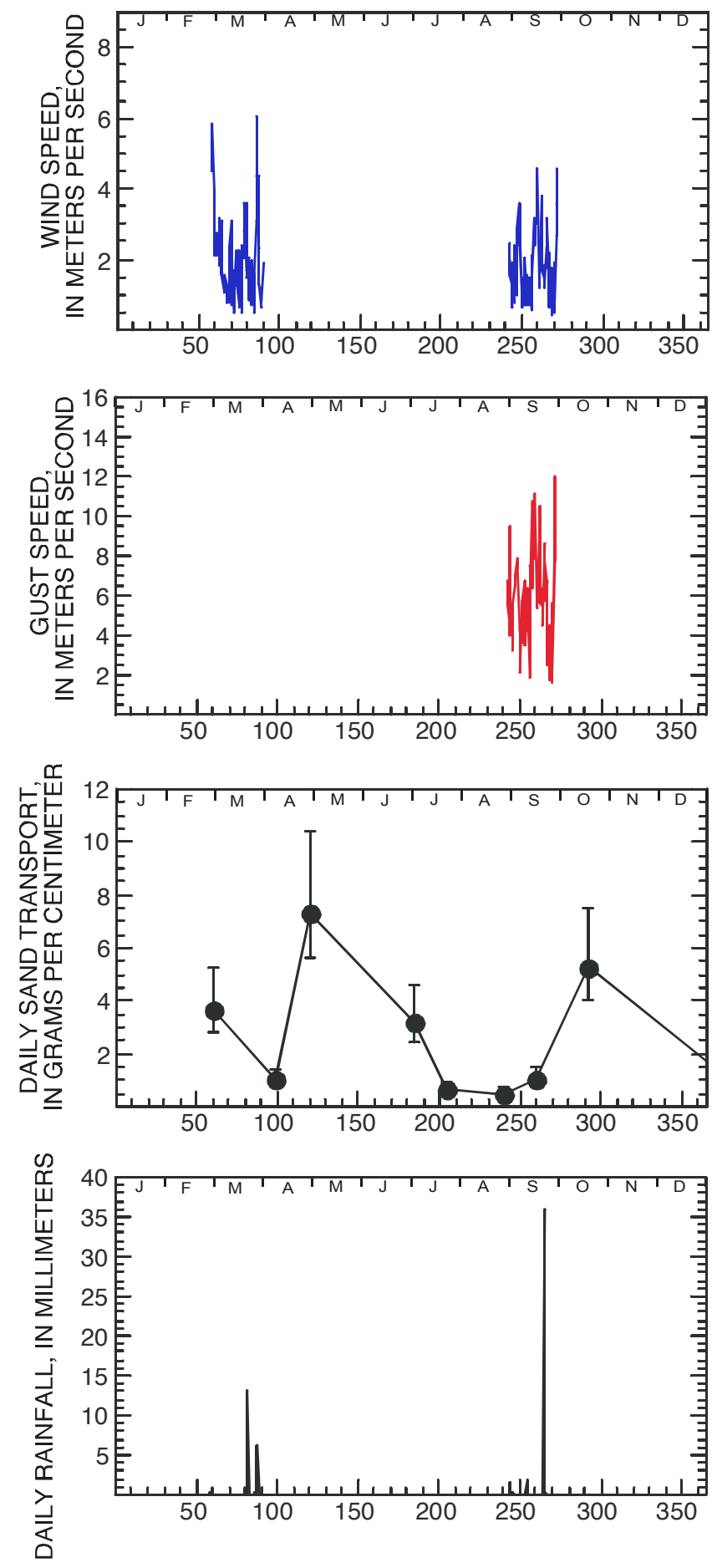

YEAR DAY
2008
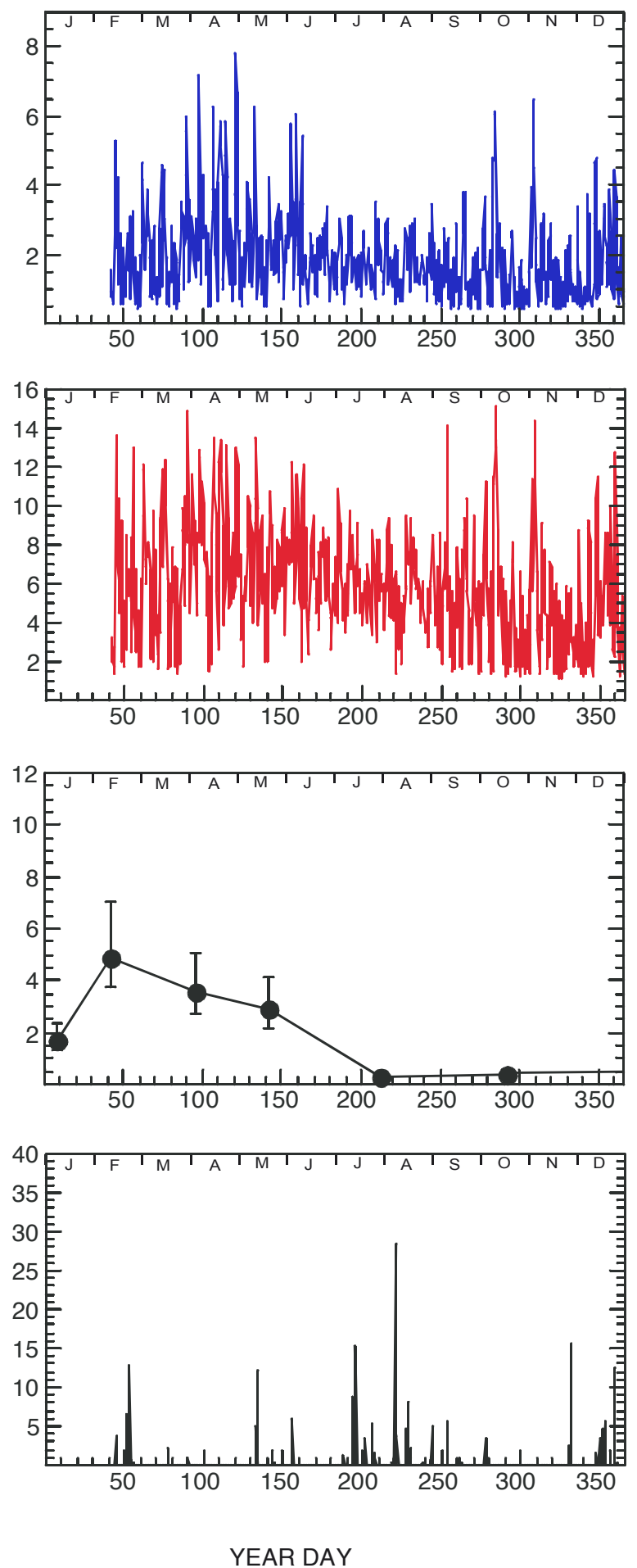

Figure 47. Wind, aeolian sand-transport, and rainfall data collected at the instrument station AZ C:13:0346 L in the Colorado River corridor, Grand Canyon, Ariz., in 2007 and 2008. Daily sand transport is plotted in grams, normalized to a width of $1 \mathrm{~cm}$. To obtain these values, total sand mass collected from four traps during each maintenance visit was divided by number of days since traps had last been emptied. Wind speed (blue plot) is presented as diurnal average values, using daytime (0600-1800 h) and nighttime (1800-0600 h) averages of data collected at 4-minute intervals. Gust speed (red plot) is shown as maximum values that occurred during each diurnal interval. Rainfall is plotted as daily (24-hour) totals. The station was not functioning during days $1-40$ of 2008 . Months are shown as single letter abbreviations at top of figure. 

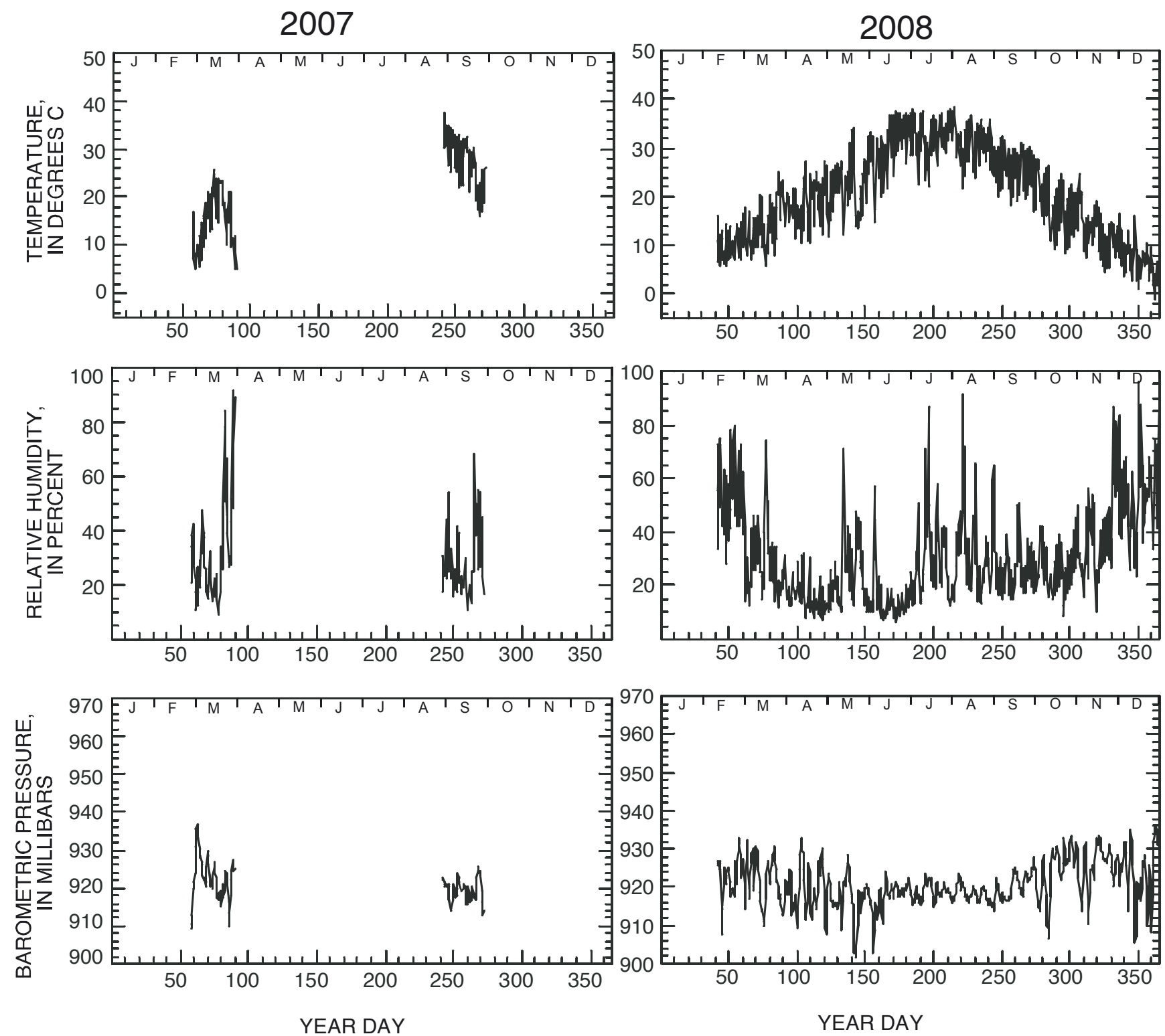

Figure 48. Temperature, humidity, and barometric pressure data collected at the instrument station AZ C:13:0346 L in the Colorado River corridor, Grand Canyon, Ariz., in 2007 and 2008. All parameters are plotted as diurnal averages (defined using 0600-1800 and $1800-0600$ hours). The station was not functioning during days $1-40$ of 2008 . Months are shown as single letter abbreviations at top of figure. 


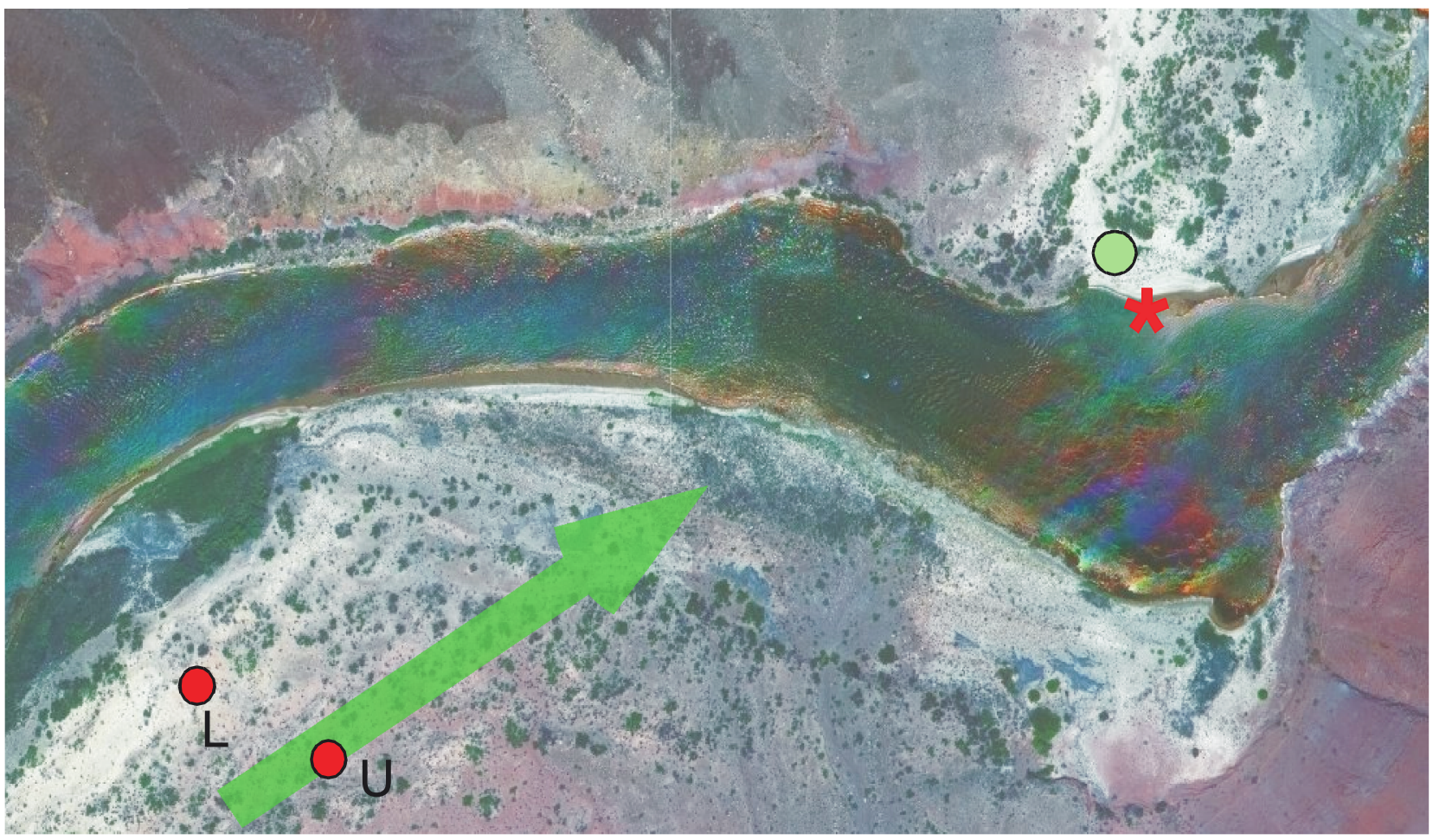

$$
\begin{aligned}
* \text { * Newly enlarged sandbar } \quad & =\text { Weather stations near AZ C:13:0346 } \\
& ==\text { Sand traps at AZ C:13:0321 }
\end{aligned}
$$

Figure 49. Aerial photograph of the area around AZ C:13:0346, in Grand Canyon, Ariz., with arrow indicating net direction of potential aeolian sediment transport measured at instrument station AZ C:13:0346 U in 2008. A vector sum of the $Q p$ proxy variable (equation 1), calculated using all available wind data from AZ C:13:0346 U in 2008, indicates net sediment transport from 237 degrees. (USGS photograph.) 


\section{4-MINUTE AVERAGE WIND SPEED, IN METERS PER SECOND \\ AND WIND DIRECTION, IN DEGREES}

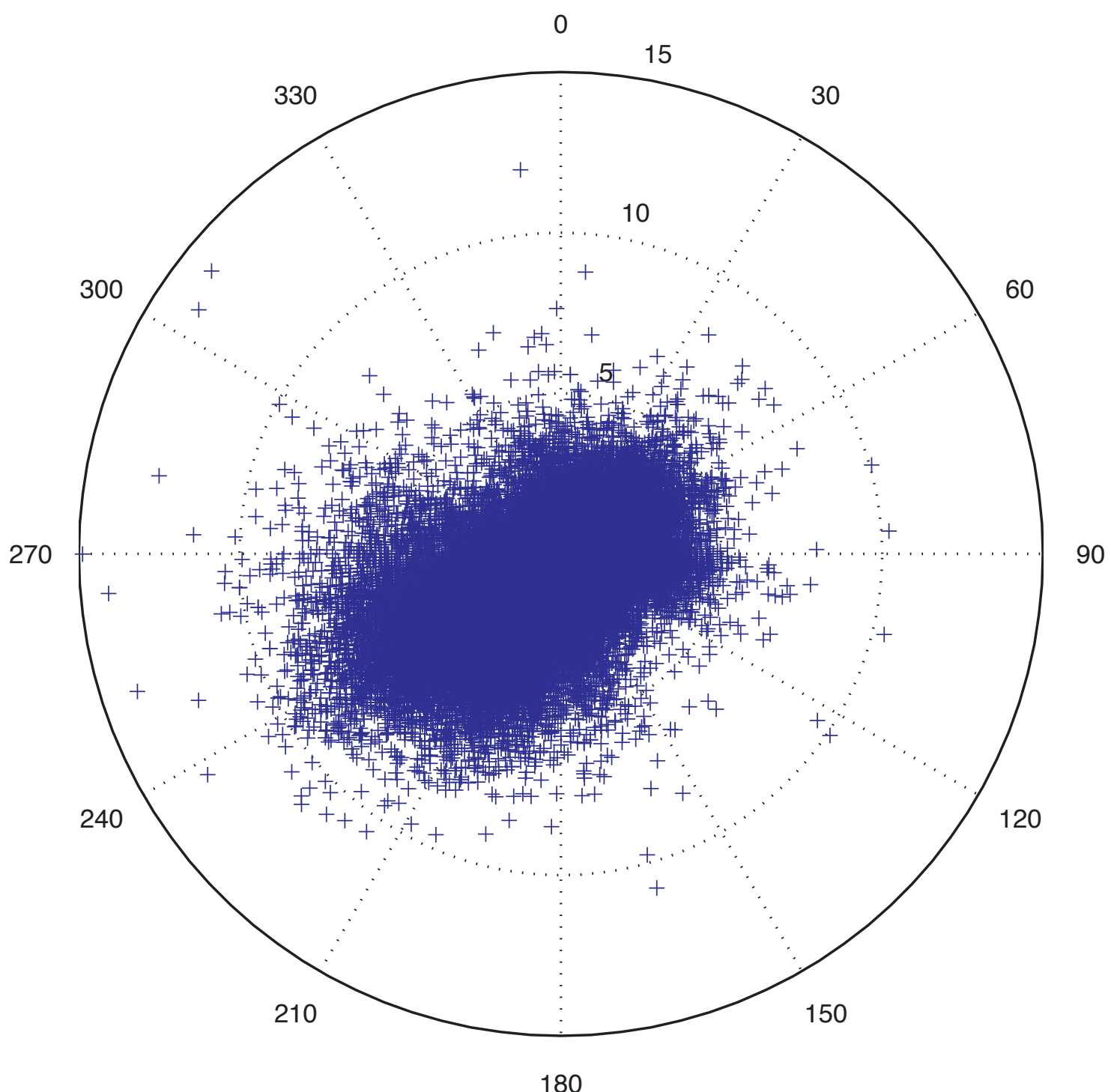

Figure 50. Magnitude and direction of wind velocity measured at the instrument station AZ C:13:0346 U in the Colorado River corridor, Grand Canyon, Ariz., at 4-minute resolution throughout 2008. Magnitude is indicated by the concentric circles, and compass bearing indicates direction from which the wind came. 


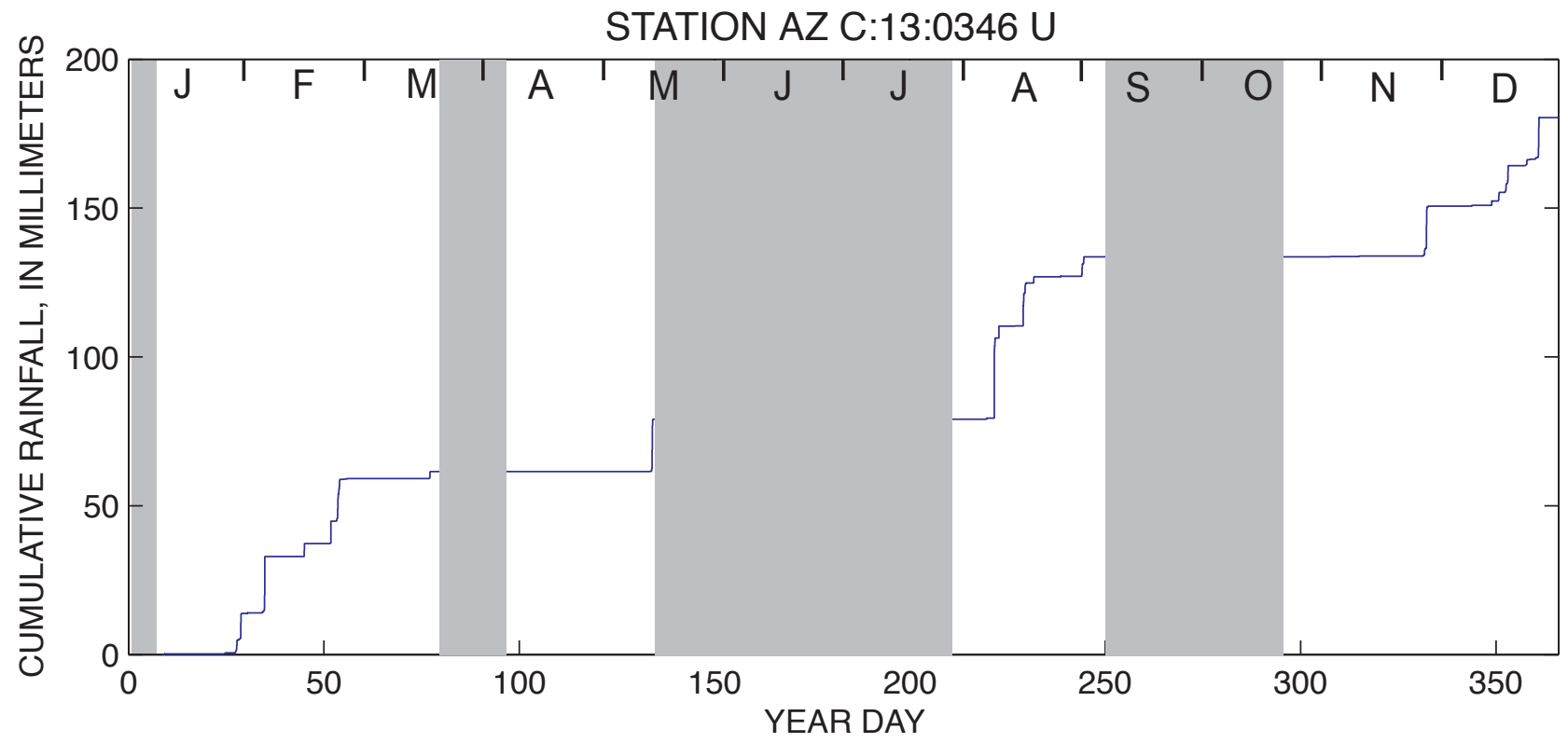

Figure 51. Cumulative 2008 rainfall record measured at AZ C:13:0346 U, compiled from data collected at 4-minute resolution. Gray shaded region indicates days when the station was not collecting data. Months are shown as single letter abbreviations at top of figure. 

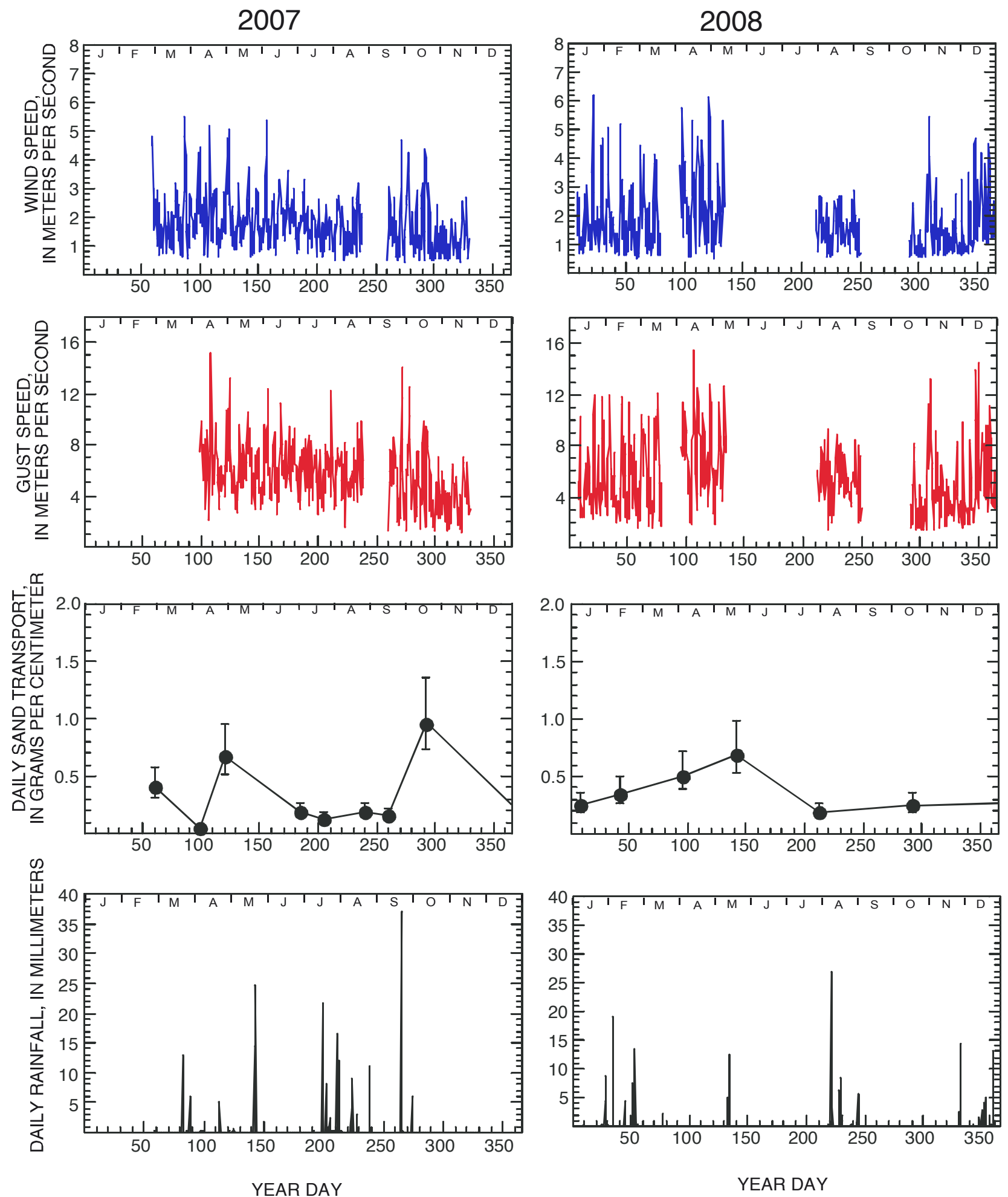

Figure 52. Wind, aeolian sand-transport, and rainfall data collected at the instrument station AZ C:13:0346 U in the Colorado River corridor, Grand Canyon, Ariz., in 2007 and 2008. Daily sand transport is plotted in grams, normalized to a width of $1 \mathrm{~cm}$. To obtain these values, total sand mass collected from four traps during each maintenance visit was divided by number of days since traps had last been emptied. Wind speed (blue plot) is presented as diurnal average values, using daytime (0600-1800 h) and nighttime (1800-0600 h) averages of data collected at 4-minute intervals. Gust speed (red plot) is shown as maximum values that occurred during each diurnal interval. Rainfall is plotted as daily (24-hour) totals. Data gaps during 2008 are discussed in the text. Months are shown as single letter abbreviations at top of figure. 

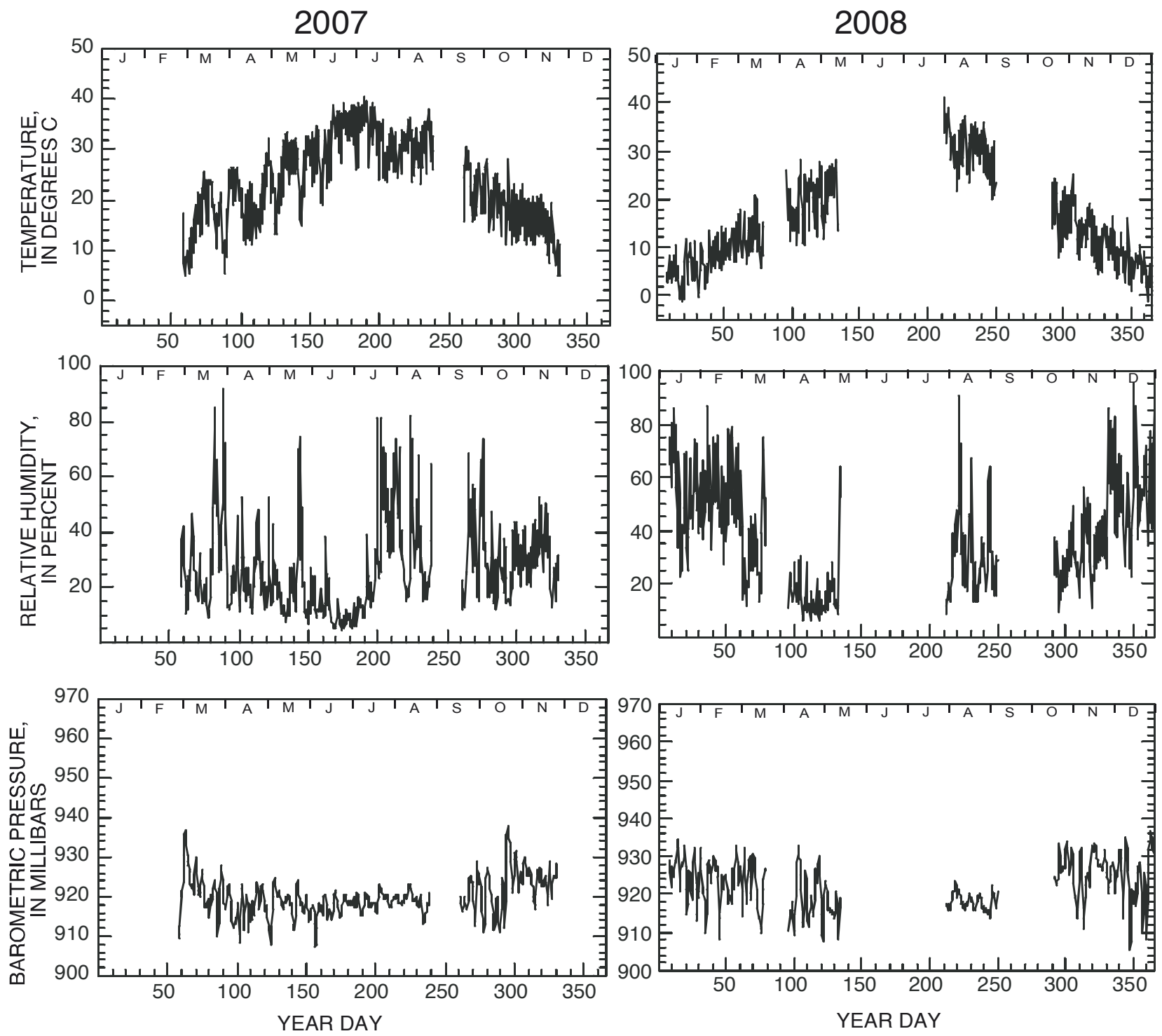

Figure 53. Temperature, humidity, and barometric pressure data collected at the instrument station AZ C:13:0346 U in the Colorado River corridor, Grand Canyon, Ariz., in 2007 and 2008. All parameters are plotted as diurnal averages (defined using 0600-1800 and 1800-0600 hours). Data gaps during 2008 are discussed in the text. Months are shown as single letter abbreviations at top of figure. 


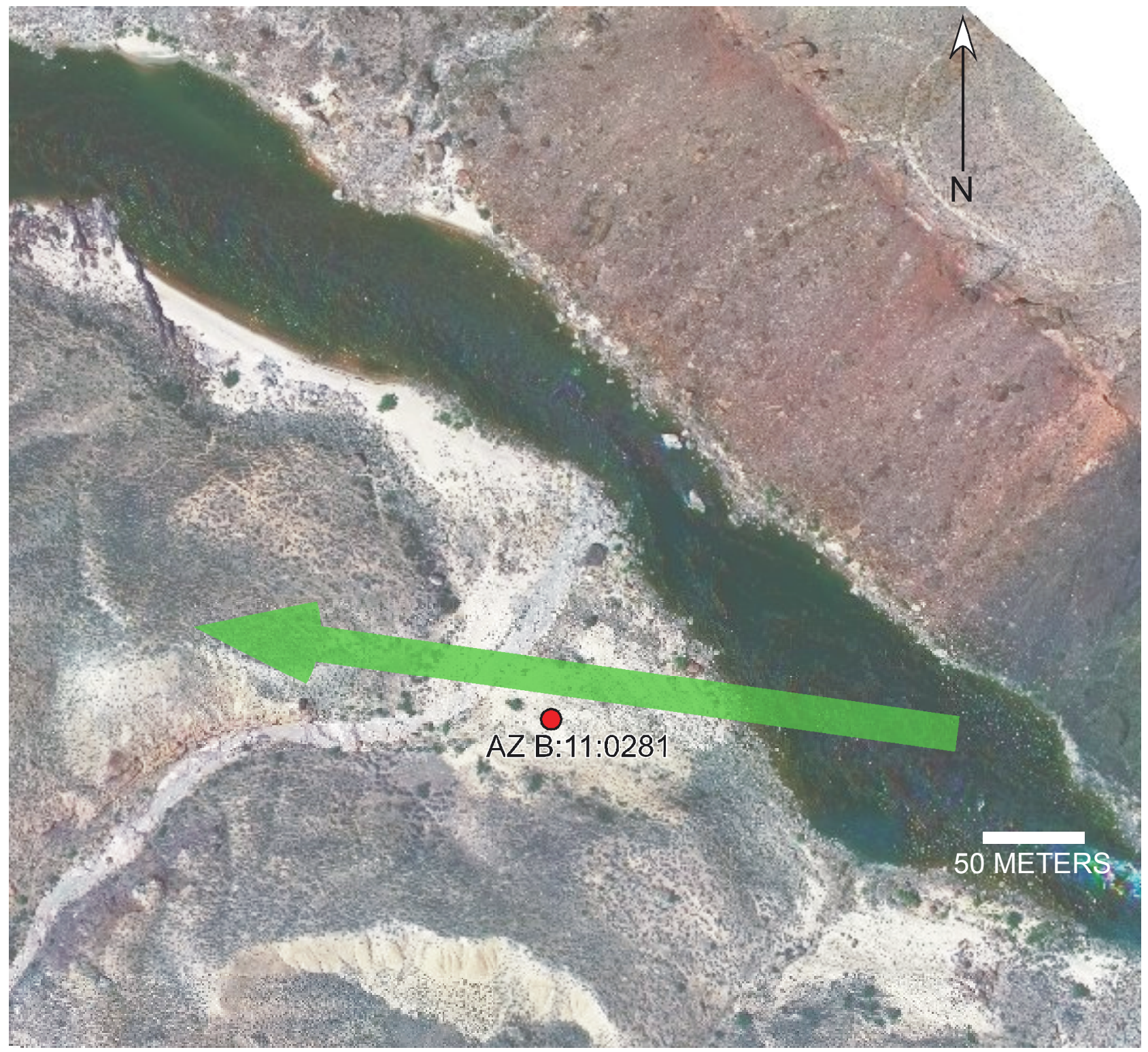

Figure 54. Aerial photograph of the area around the instrument station near AZ B:11:0281, in Grand Canyon, Ariz., with arrow indicating net direction of potential aeolian sediment transport measured in 2008. A vector sum of the $Q p$ proxy variable (equation 1), calculated using all available wind data from AZ B:11:0281 in 2008, indicates net sediment transport from 99 degrees. (USGS photograph.) 


\section{4-MINUTE AVERAGE WIND SPEED, IN METERS PER SECOND AND WIND DIRECTION, IN DEGREES}

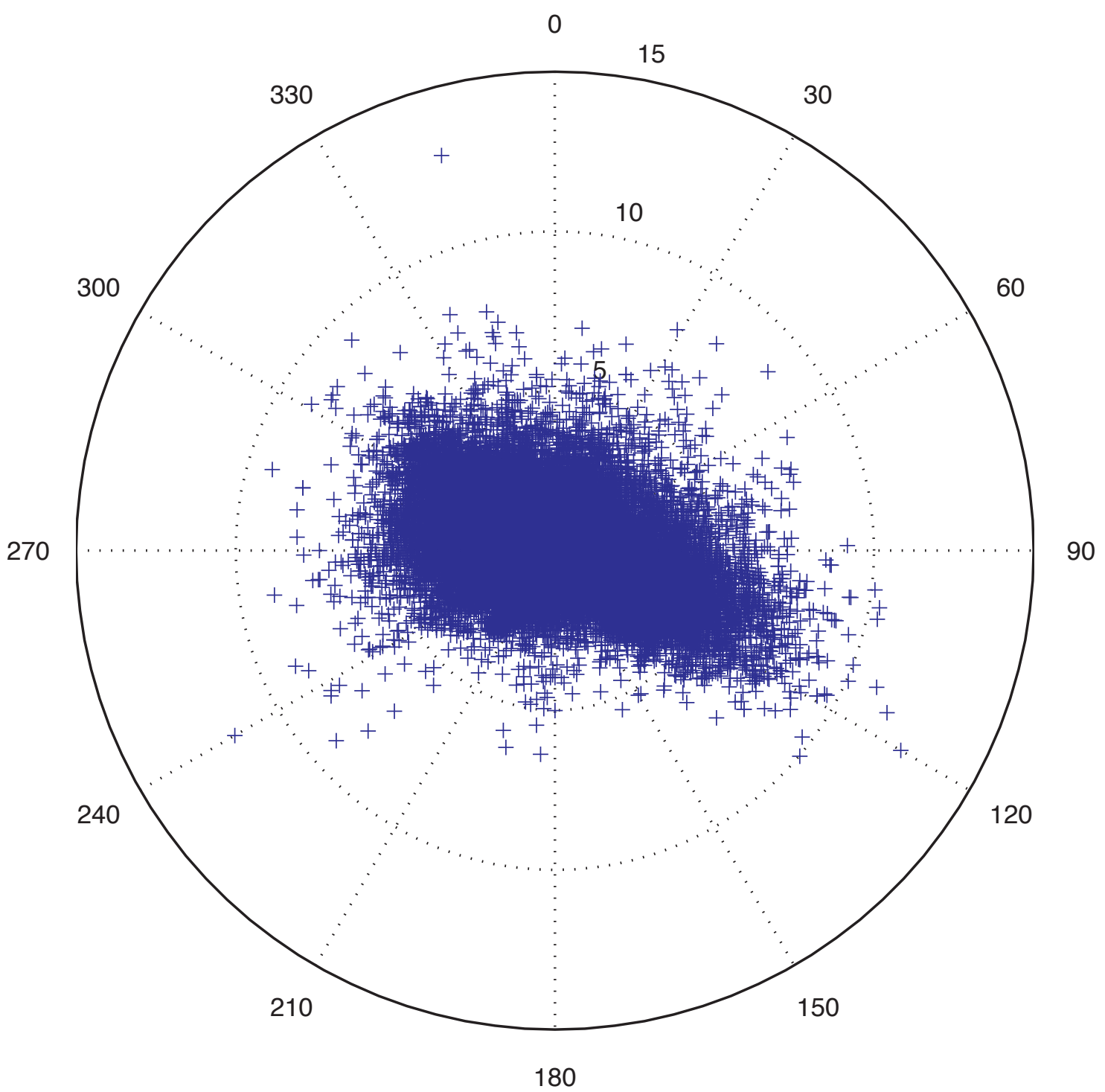

Figure 55. Magnitude and direction of wind velocity measured at the instrument station AZ B:11:0281 in the Colorado River corridor, Grand Canyon, Ariz., at 4-minute resolution throughout 2008. Magnitude is indicated by the concentric circles, and compass bearing indicates direction from which the wind came. 


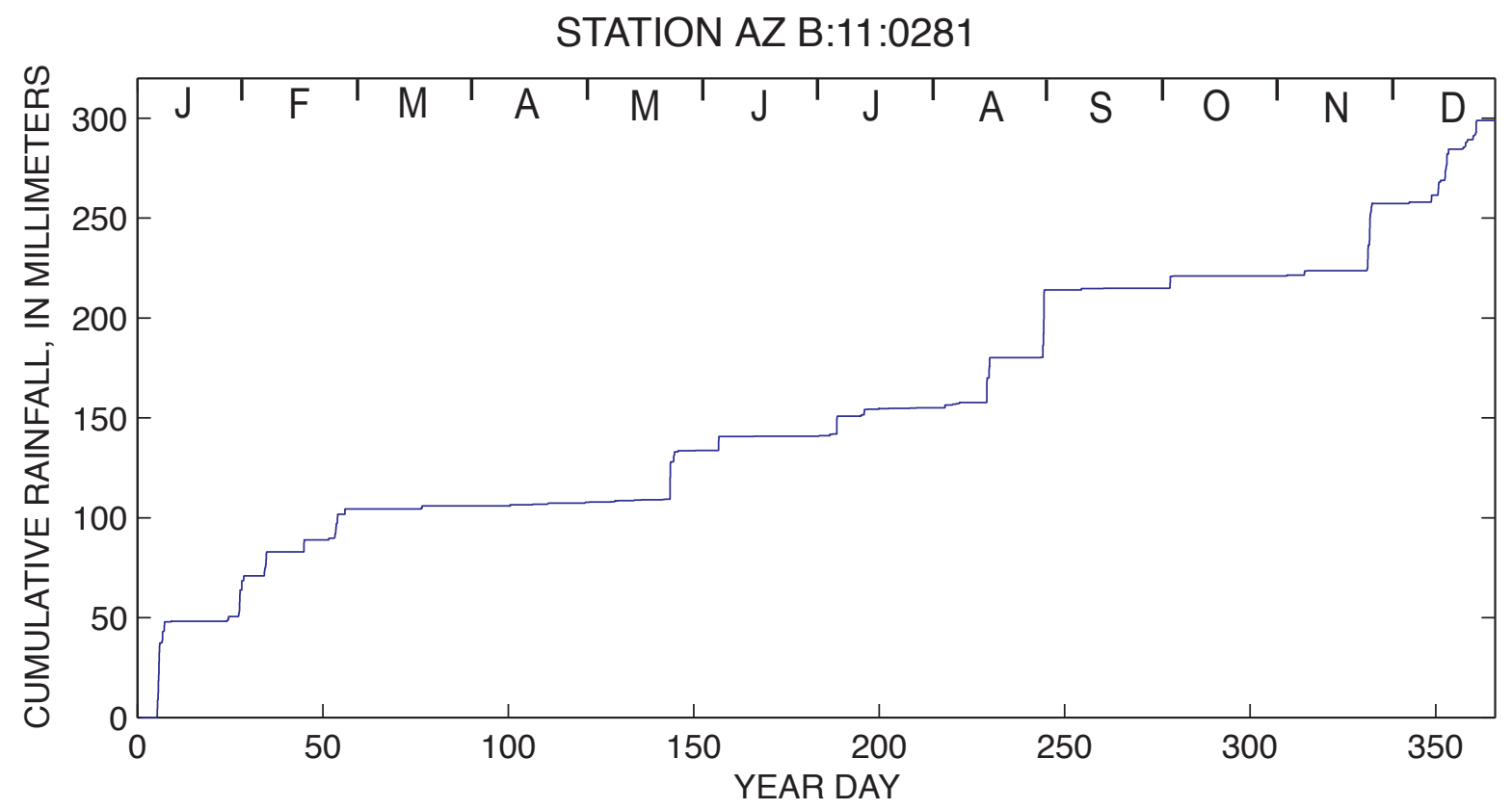

Figure 56. Cumulative 2008 rainfall record measured at AZ B:11:0281, compiled from data collected at 4-minute resolution. Months are shown as single letter abbreviations at top of figure. 

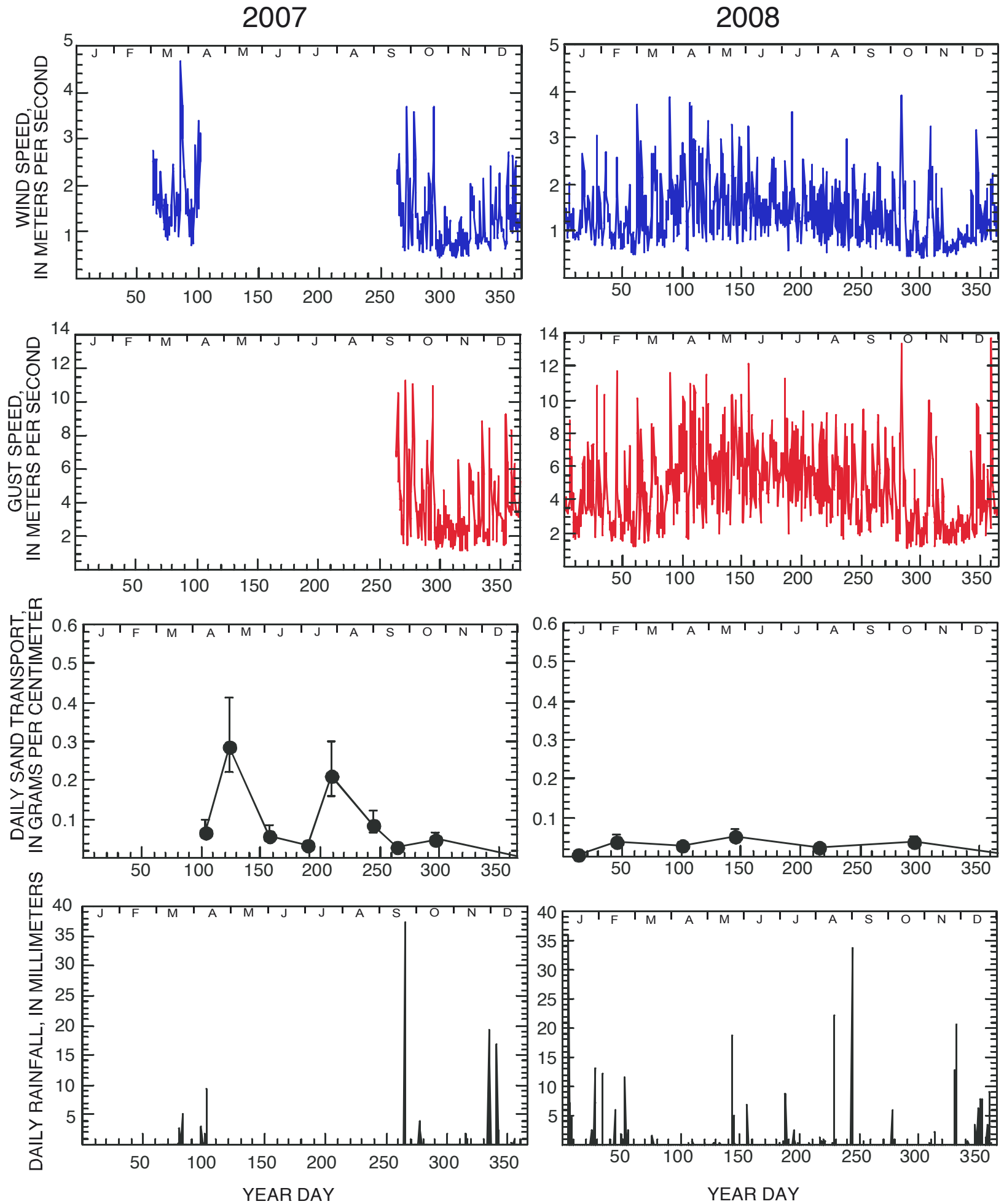

Figure 57. Wind, aeolian sand-transport, and rainfall data collected at the instrument station AZ B:11:0281 in the Colorado River corridor, Grand Canyon, Ariz., in 2007 and 2008. Daily sand transport is plotted in grams, normalized to a width of $1 \mathrm{~cm}$. To obtain these values, total sand mass collected from four traps during each maintenance visit was divided by number of days since traps had last been emptied. Wind speed (blue plot) is presented as diurnal average values, using daytime (0600-1800 h) and nighttime (1800-0600 h) averages of data collected at 4-minute intervals. Gust speed (red plot) is shown as maximum values that occurred during each diurnal interval. Rainfall is plotted as daily (24-hour) totals. Months are shown as single letter abbreviations at top of figure. 

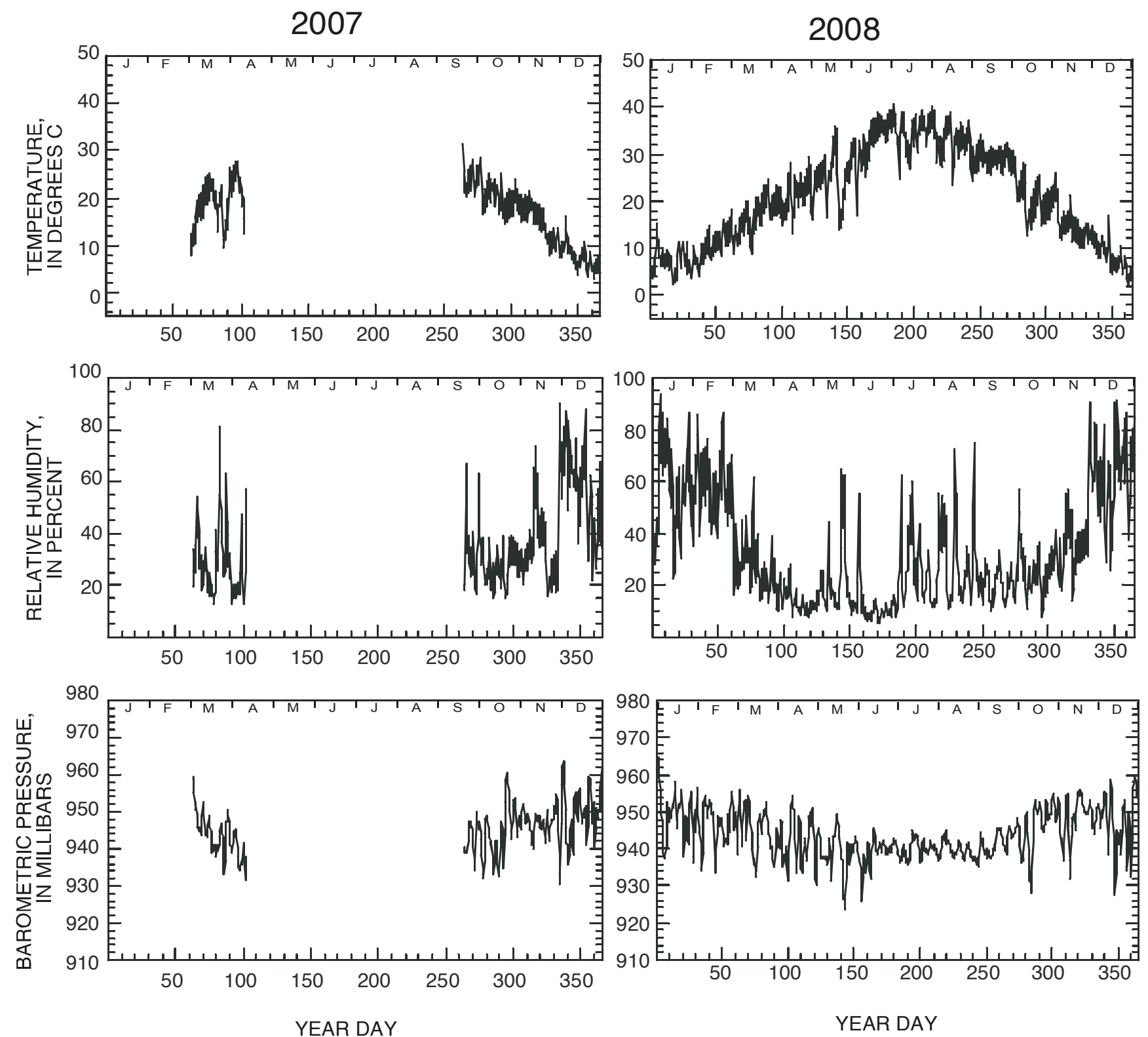

Figure 58. Temperature, humidity, and barometric pressure data collected at the instrument station AZ B:11:0281 in the Colorado River corridor, Grand Canyon, Ariz., in 2007 and 2008. All parameters are plotted as diurnal averages (defined using 0600-1800 and 1800-0600 hours). Months are shown as single letter abbreviations at top of figure. 


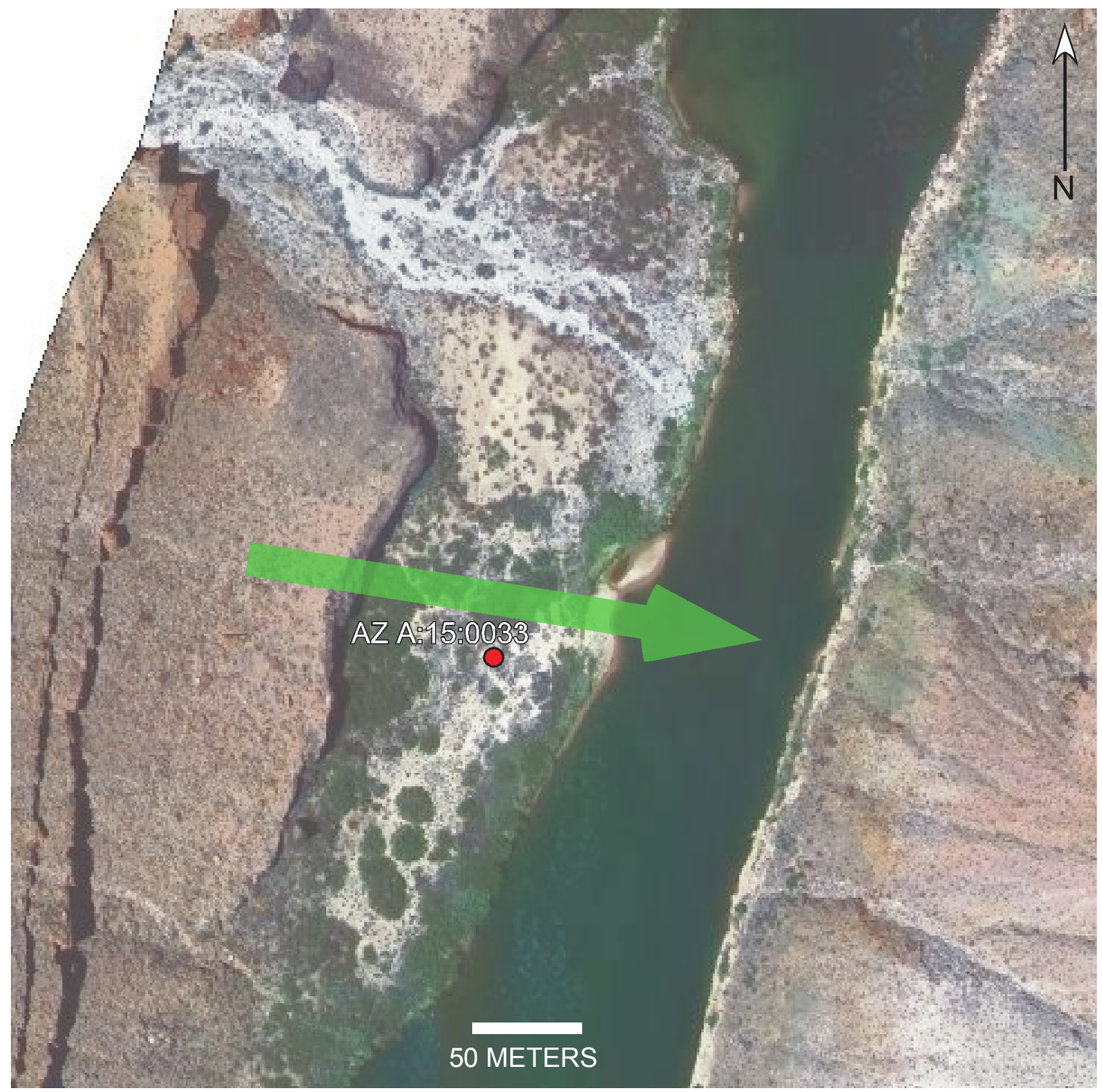

Figure 59. Aerial photograph of the area around the instrument station near AZ A:15:0033, in Grand Canyon, Ariz., with arrow indicating net direction of potential aeolian sediment transport measured in 2008. A vector sum of the $Q p$ proxy variable (equation 1), calculated using all available wind data from AZ A:15:0033 in 2008, indicates net sediment transport from 276 degrees. (USGS photograph.) 


\section{4-MINUTE AVERAGE WIND SPEED, IN METERS PER SECOND AND WIND DIRECTION, IN DEGREES}

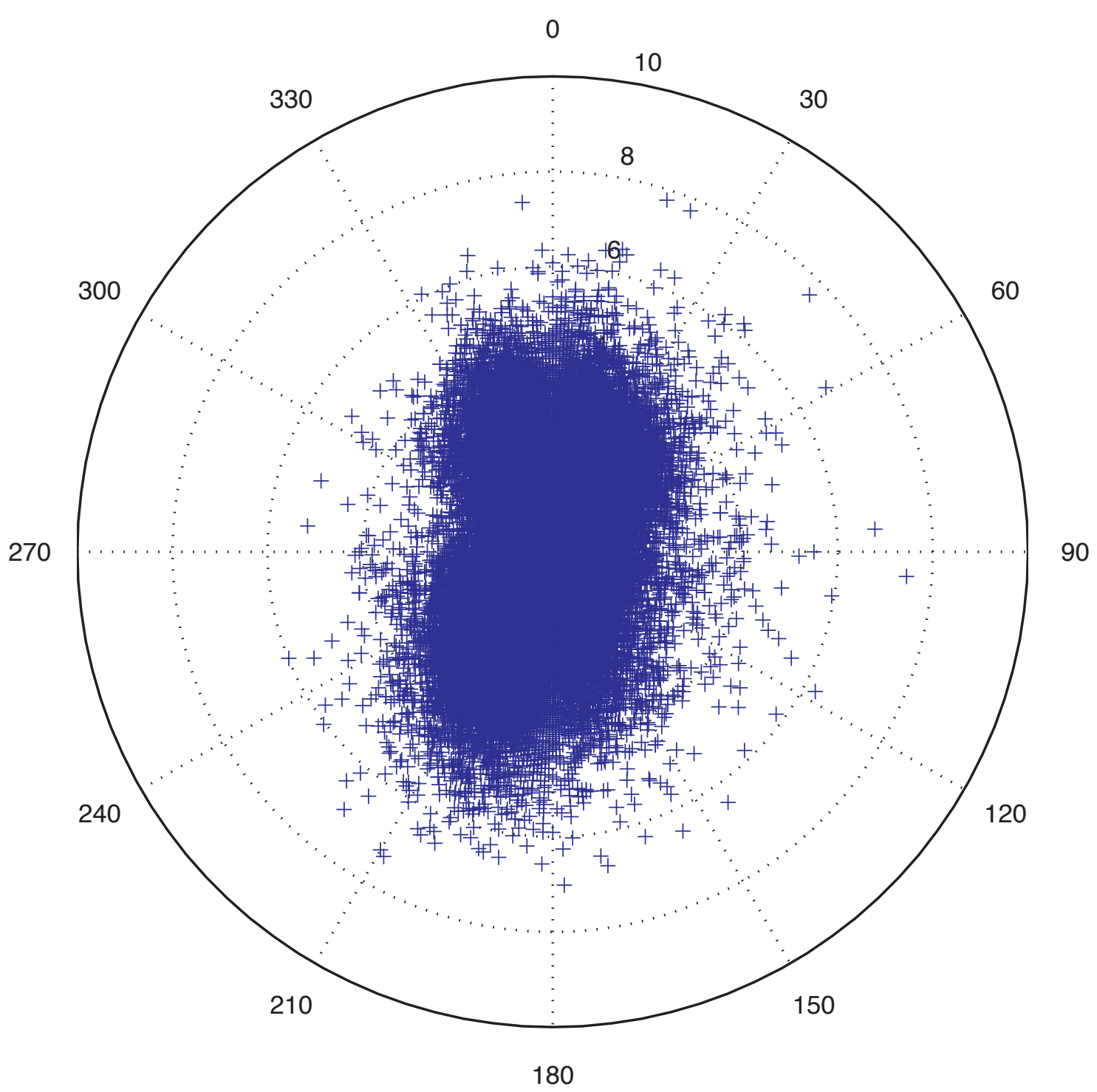

Figure 60. Magnitude and direction of wind velocity measured at the instrument station AZ A:15:0033 in the Colorado River corridor, Grand Canyon, Ariz., at 4-minute resolution throughout 2008. Magnitude is indicated by the concentric circles, and compass bearing indicates direction from which the wind came. 
STATION AZ A:15:0033

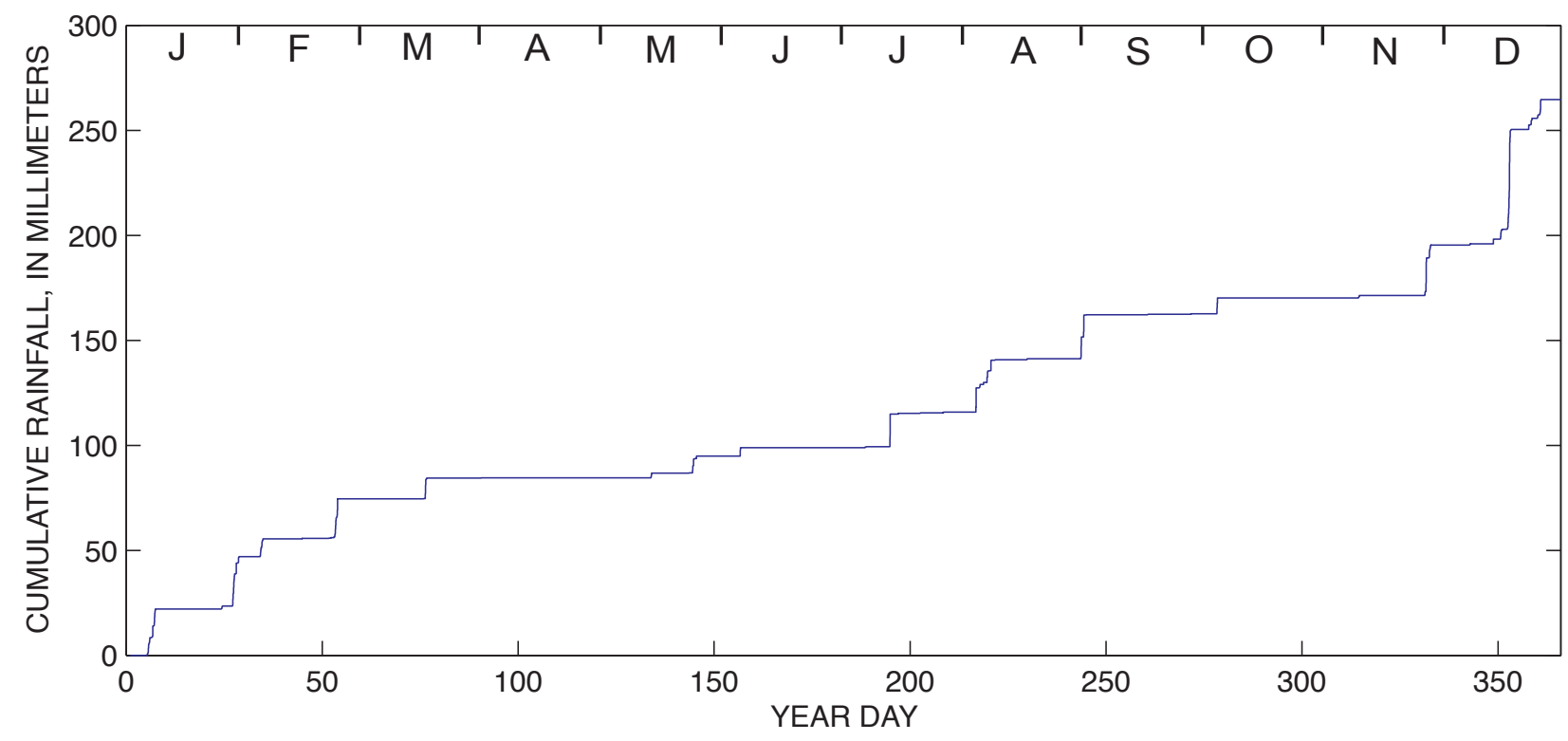

Figure 61. Cumulative 2008 rainfall record measured at AZ A:15:0033, compiled from data collected at 4-minute resolution. Months are shown as single letter abbreviations at top of figure. 

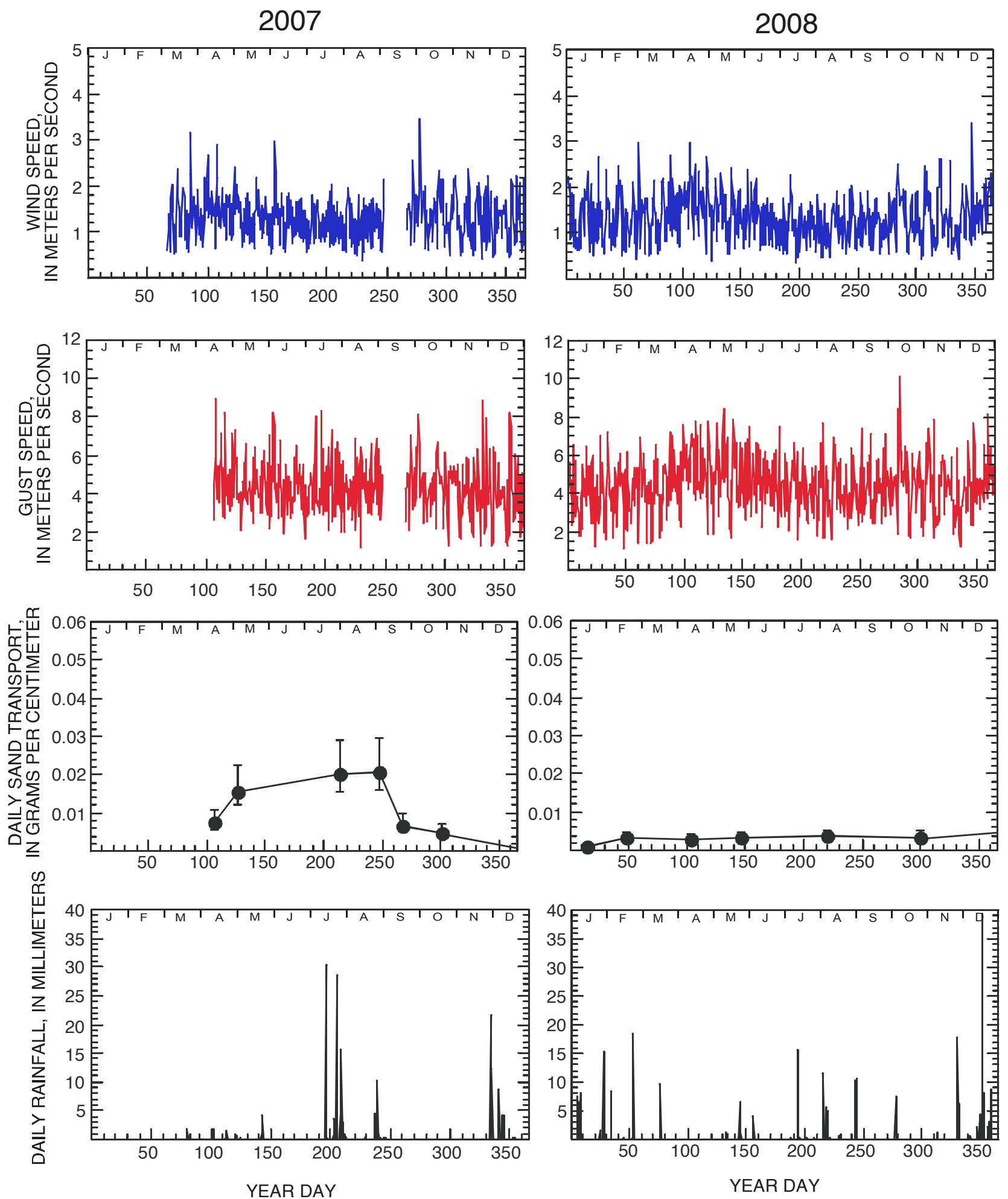

Figure 62. Wind, aeolian sand-transport, and rainfall data collected at the instrument station AZ A:15:0033 in the Colorado River corridor, Grand Canyon, Ariz., in 2007 and 2008. Daily sand transport is plotted in grams, normalized to a width of $1 \mathrm{~cm}$. To obtain these values, total sand mass collected from four traps during each maintenance visit was divided by number of days since traps had last been emptied. Wind speed (blue plot) is presented as diurnal average values, using daytime (0600-1800 h) and nighttime (1800-0600 h) averages of data collected at 4-minute intervals. Gust speed (red plot) is shown as maximum values that occurred during each diurnal interval. Rainfall is plotted as daily (24-hour) totals. Months are shown as single letter abbreviations at top of figure. 

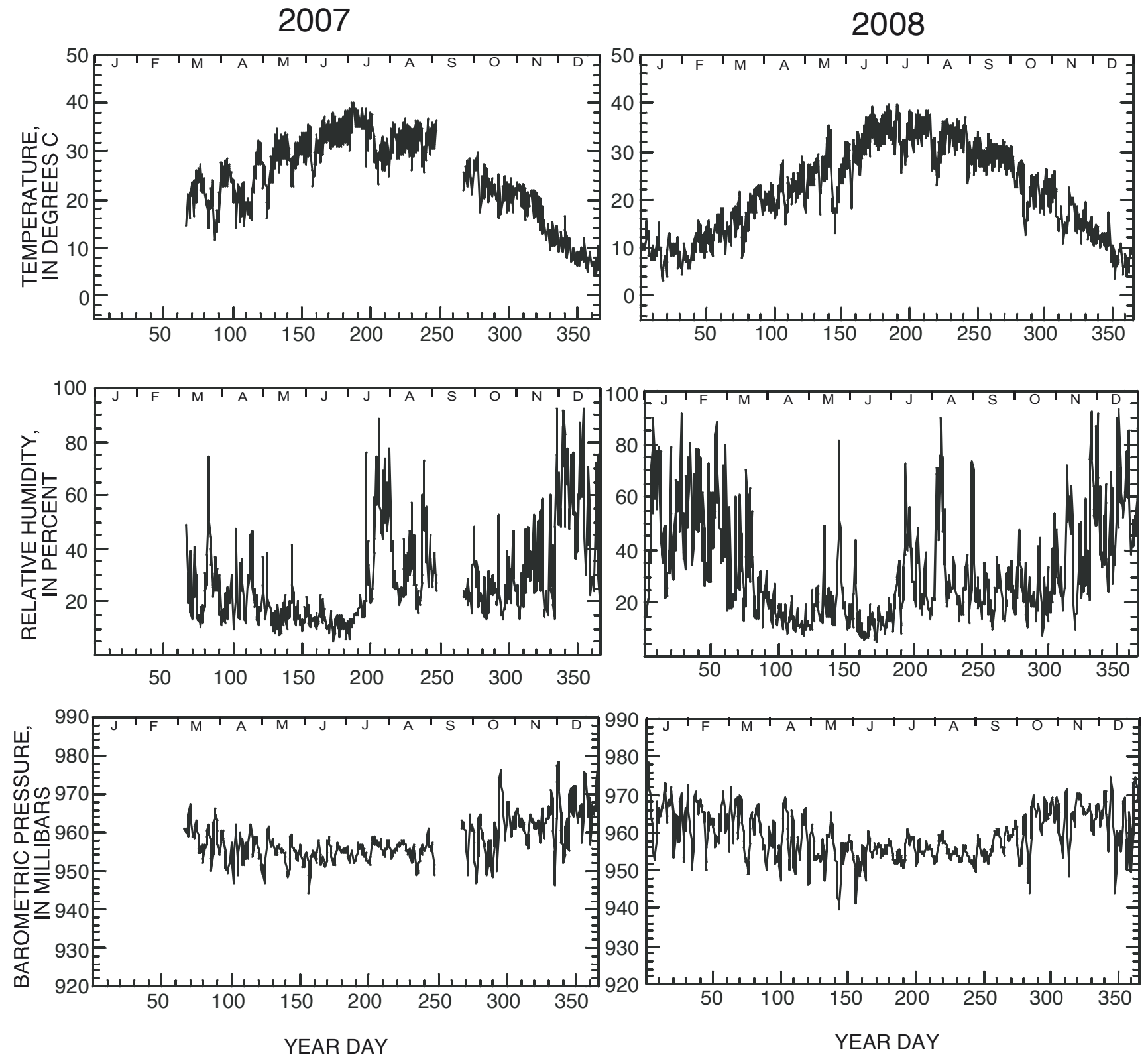

Figure 63. Temperature, humidity, and barometric pressure data collected at the instrument station AZ A:15:0033 in the Colorado River corridor, Grand Canyon, Ariz., in 2007 and 2008. All parameters are plotted as diurnal averages (defined using 0600-1800 and 1800-0600 hours). Months are shown as single letter abbreviations at top of figure. 


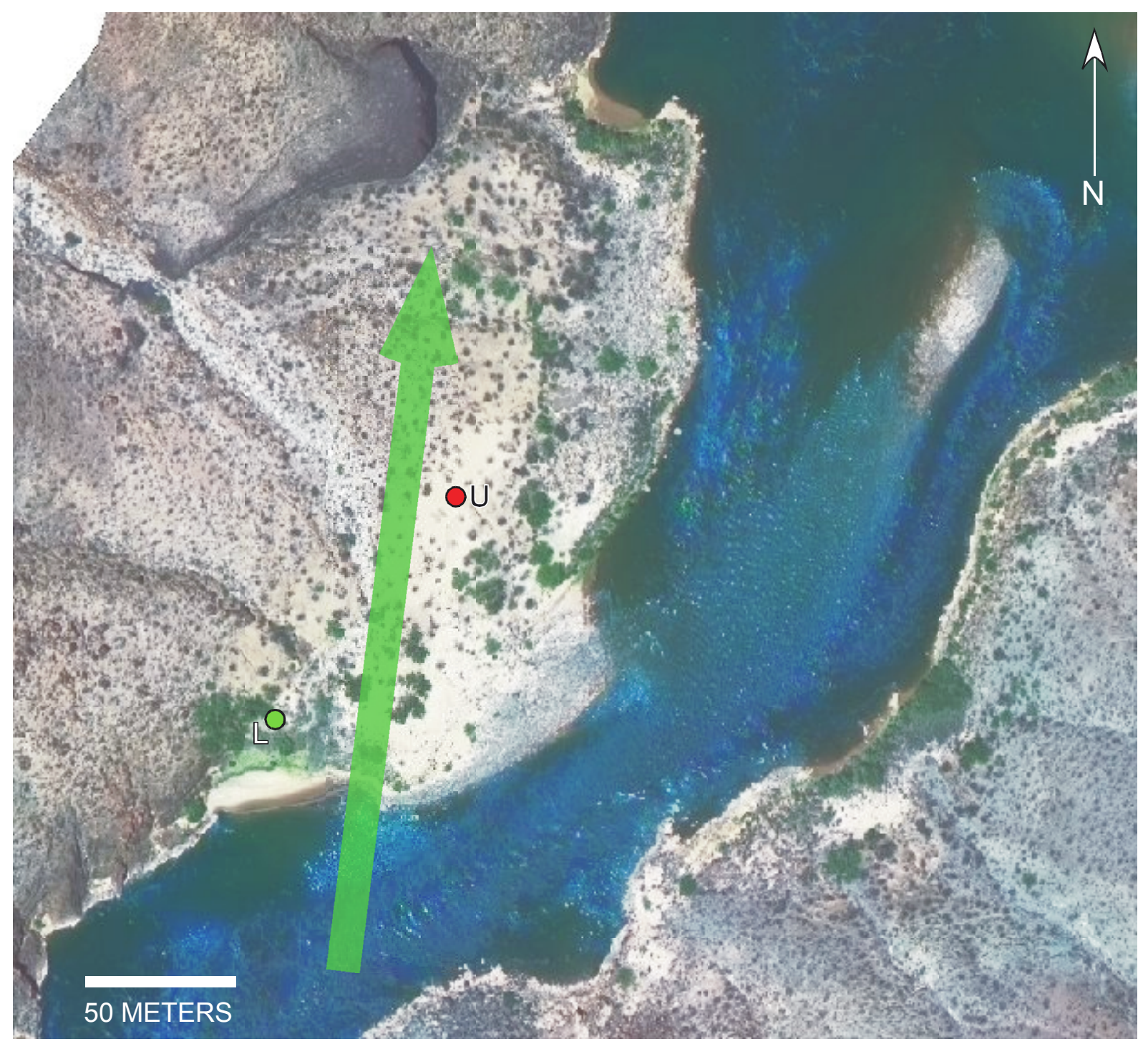

Figure 64. Aerial photograph of the area around the instrument station near AZ G:03:0072, in Grand Canyon, Ariz., with arrow indicating net direction of potential aeolian sediment transport measured at AZ G:03:0072 $\mathrm{U}$ in 2008. A vector sum of the $Q p$ proxy variable (equation 1), calculated using all available wind data from AZ G:03:0072 U in 2008, indicates net sediment transport from 187 degrees. (USGS photograph.) 


\section{4-MINUTE AVERAGE WIND SPEED, IN METERS PER SECOND AND WIND DIRECTION, IN DEGREES}

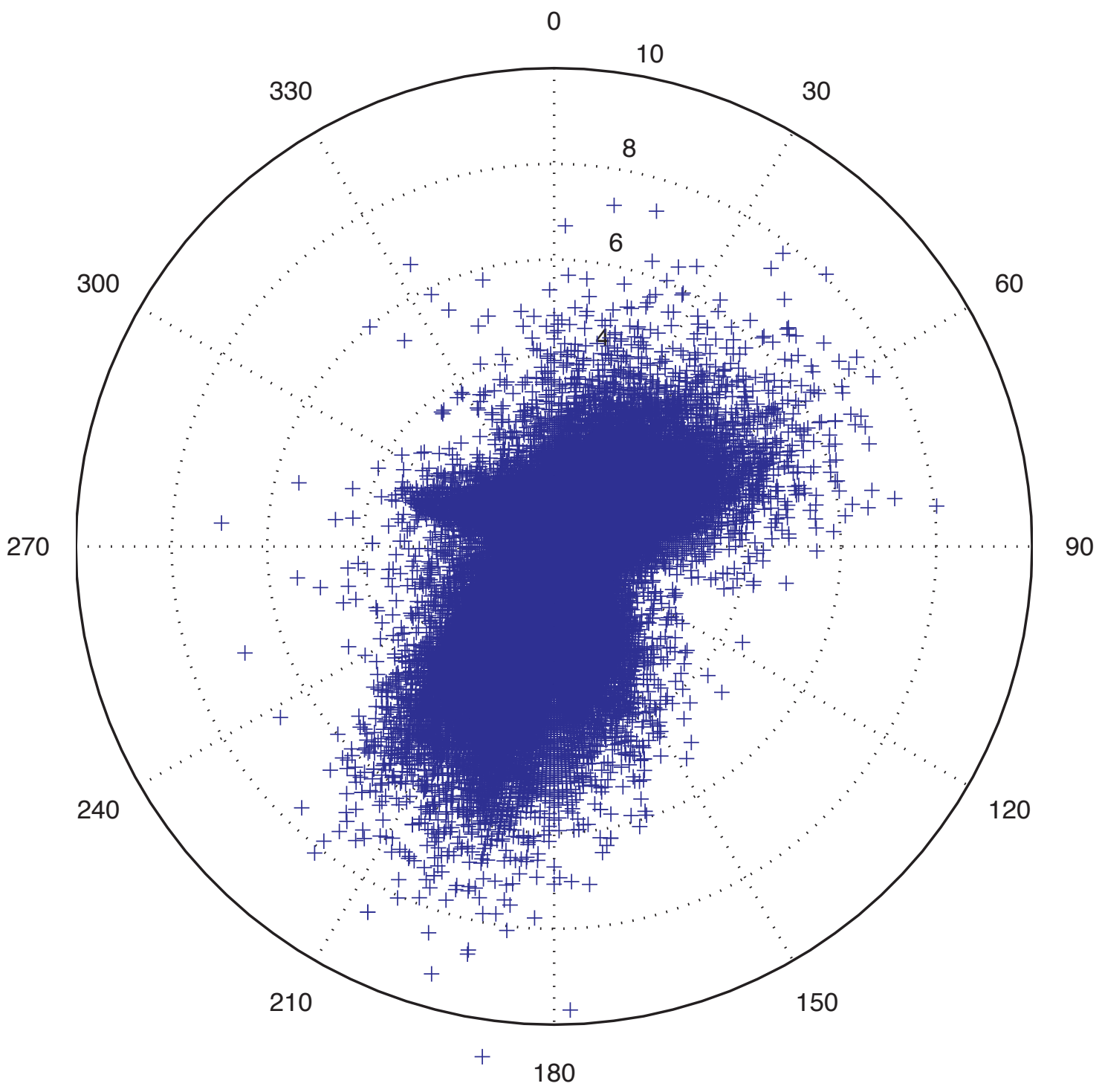

Figure 65. Magnitude and direction of wind velocity measured at the instrument station AZ G:03:0072 U in the Colorado River corridor, Grand Canyon, Ariz., at 4-minute resolution throughout 2008. Magnitude is indicated by the concentric circles, and compass bearing indicates direction from which the wind came. 
STATION AZ G:03:0072

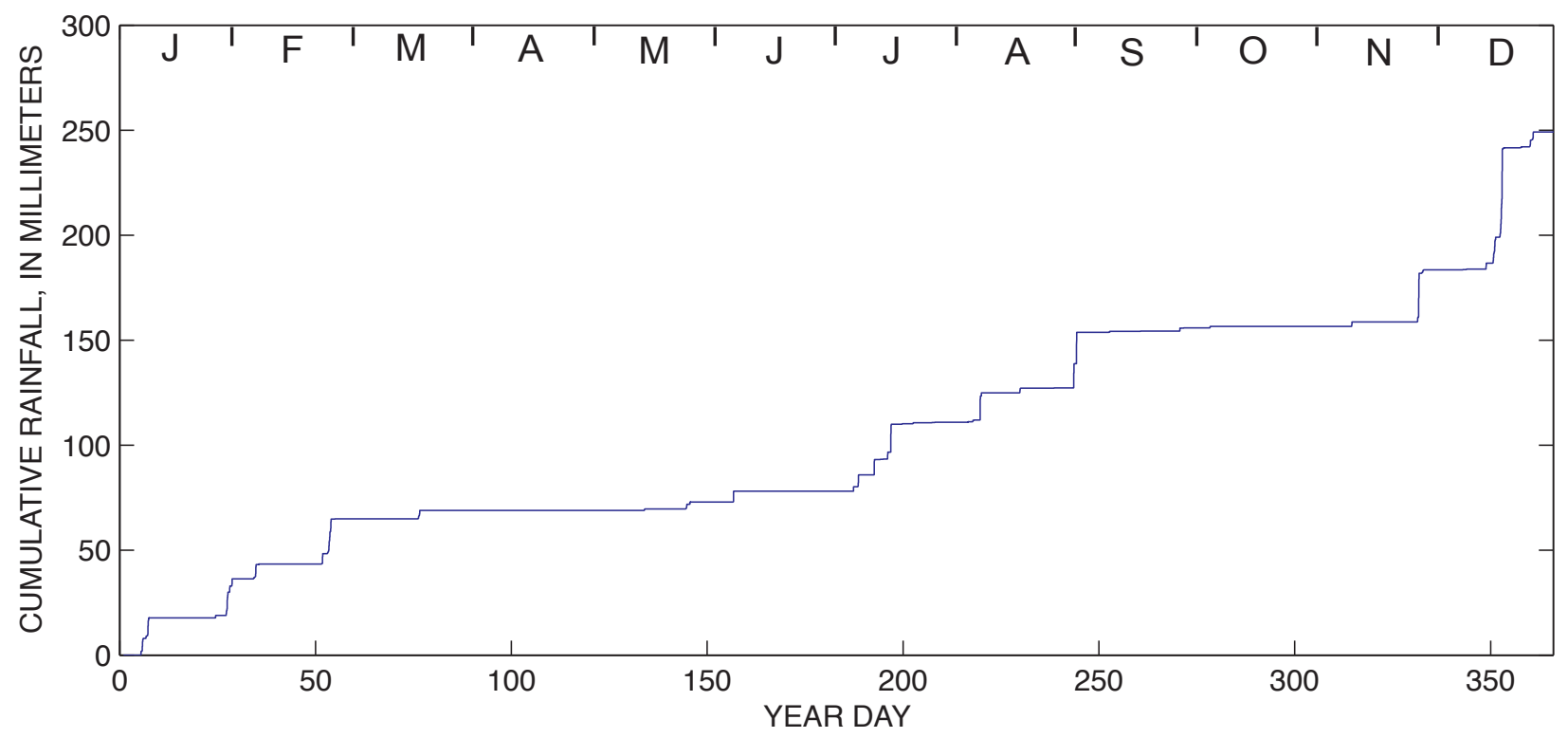

Figure 66. Cumulative 2008 rainfall record measured at $A Z \mathrm{G}: 03: 0072 \mathrm{U}$, compiled from data collected at 4-minute resolution. Months are shown as single letter abbreviations at top of figure. 

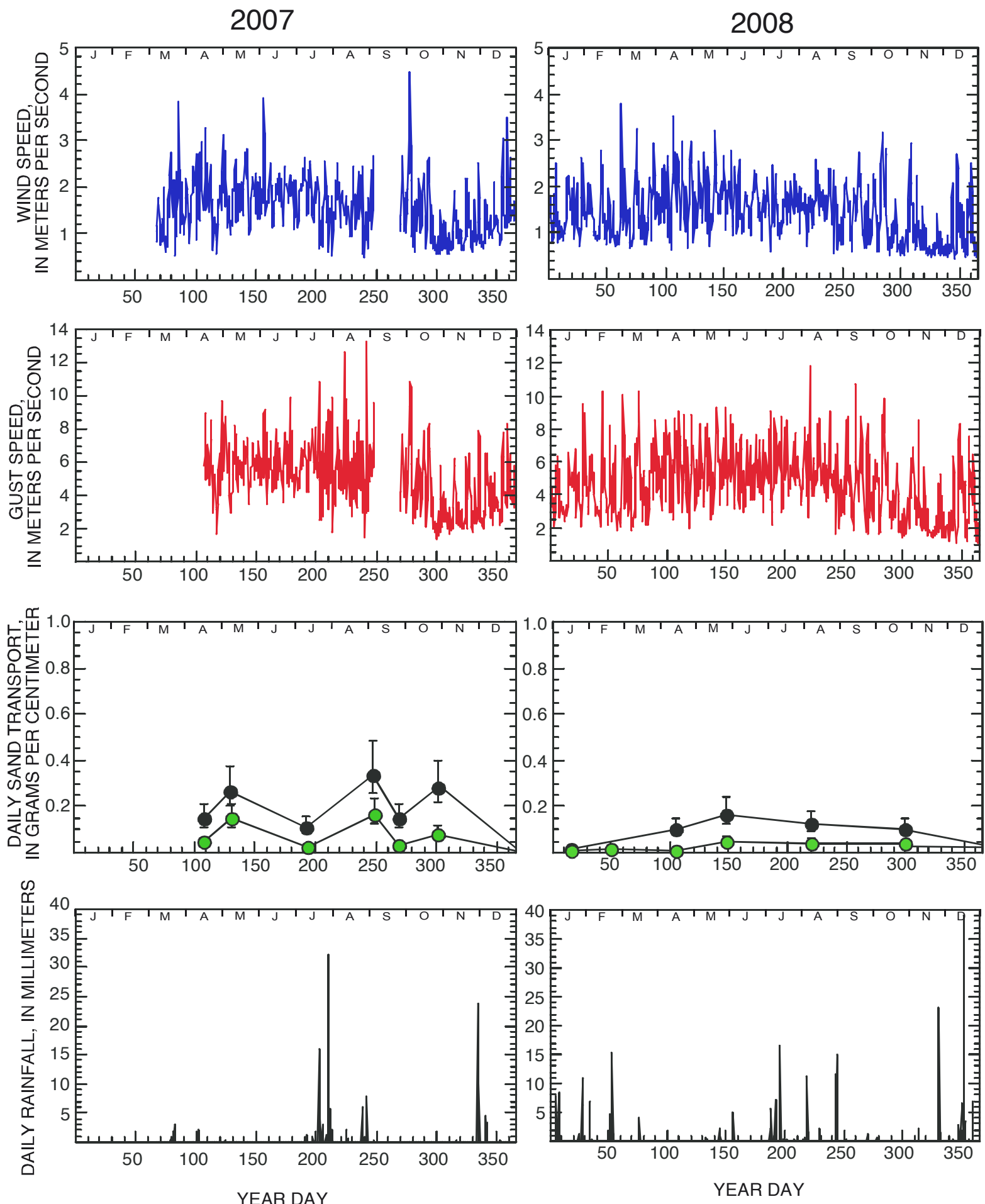

Figure 67. Wind, aeolian sand-transport, and rainfall data collected at the instrument station AZ G:03:0072 U, and aeolian sandtransport data collected in sand traps at AZ G:03:0072 L (green circles), in the Colorado River corridor, Grand Canyon, Ariz., in 2007 and 2008. Daily sand transport is plotted in grams, normalized to a width of $1 \mathrm{~cm}$. To obtain these values, total sand mass collected from four traps during each maintenance visit was divided by number of days since traps had last been emptied. Wind speed (blue plot) is presented as diurnal average values, using daytime $(0600-1800 \mathrm{~h})$ and nighttime $(1800-0600 \mathrm{~h})$ averages of data collected at 4-minute intervals. Gust speed (red plot) is shown as maximum values that occurred during each diurnal interval. Rainfall is plotted as daily (24-hour) totals. Months are shown as single letter abbreviations at top of figure. 

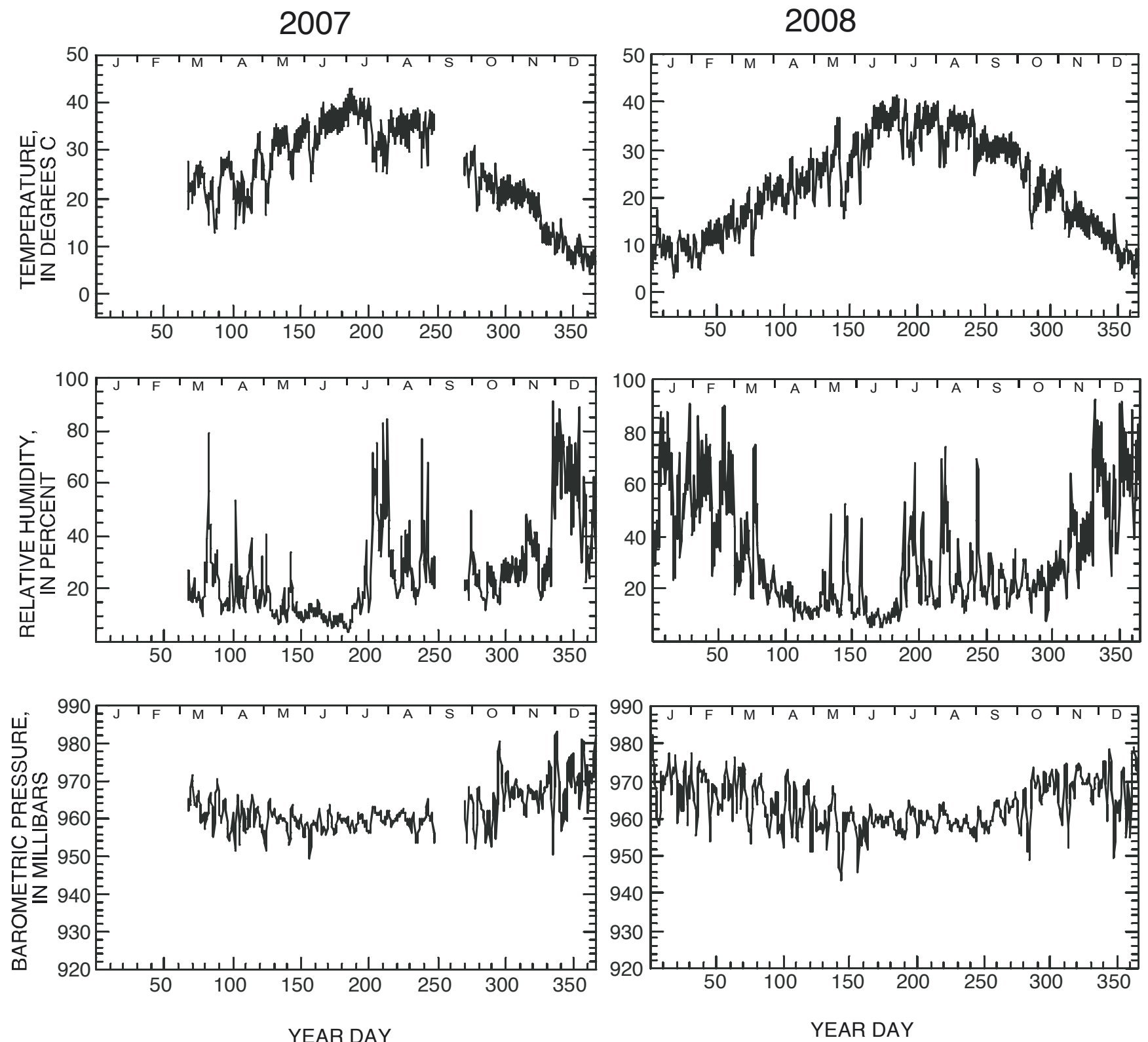

Figure 68. Temperature, humidity, and barometric pressure data collected the instrument station AZ G:03:0072 U in the Colorado River corridor, Grand Canyon, Ariz., in 2007 and 2008. All parameters are plotted as diurnal averages (defined using 0600-1800 and 1800-0600 hours). Months are shown as single letter abbreviations at top of figure. 


\section{Tables}

Table 1. Approximate river miles, station names, abbreviations, and equipment deployed at each study site, month in which the station was established, and setting of aeolian dunes at each site.

[Modern Fluvial Sourced [MFS], Relict Fluvial Sourced [RFS], or intermediate, receiving some sand from modern fluvial deposits and some from relict deposits)]

\begin{tabular}{|c|c|c|c|c|}
\hline $\begin{array}{c}\text { Approximate river } \\
\text { mile }\end{array}$ & Station name & Equipment & Date established & Dune field type \\
\hline 25 & AZ C:05:0031 L & weather station, sand traps & $2 / 23 / 2007$ & MFS \\
\hline 60 & AZ C:13:0365 L & weather station, sand traps & $2 / 9 / 2008$ & MFS \\
\hline 60 & AZ C:13:0006 & weather station, sand traps & $2 / 25 / 2007$ & MFS? \\
\hline 65 & AZ C:13:0336 U & weather station, sand traps & $2 / 26 / 2007$ & RFS \\
\hline 65 & AZ C:13:0336 L & sand traps & $2 / 9 / 2008$ & on cobble bar \\
\hline 70 & AZ C:13:0321 & sand traps & $2 / 10 / 2008$ & MFS \\
\hline 135 & AZ B:11:0281 & weather station, sand traps & $3 / 4 / 2007$ & intermediate \\
\hline 203 & AZ A:15:0033 & weather station, sand traps & $3 / 7 / 2007$ & RFS \\
\hline 223 & AZ G:03:0072 L & sand traps & $3 / 8 / 2007$ & MFS \\
\hline 223 & AZ G:03:0072 U & weather station, sand traps & $3 / 8 / 2007$ & MFS \\
\hline
\end{tabular}


Table 2. Total rainfall, in $\mathrm{mm}$, recorded daily at each of the weather stations.

[N/A indicates that the station did not collect data that day]

\begin{tabular}{|c|c|c|c|c|c|c|c|c|c|c|c|c|}
\hline Date & AZ C:05:0031 L & AZ C:05:0031 U & AZ C:13:0365 L & AZ C:13:0365 U & AZ C:13:0006 & AZ C:13:0336 U & AZ C:13:0346 L & AZ C:13:0346 U & AZ B:11:0281 & AZ A:15:0033 & AZ G:03:0072 U & $\begin{array}{l}\text { Year } \\
\text { Day }\end{array}$ \\
\hline $1 / 1 / 08$ & 0 & 0 & N/A & N/A & 0 & 0 & N/A & N/A & 0 & 0 & 0 & 1 \\
\hline $1 / 2 / 08$ & 0 & 0 & N/A & N/A & 0 & 0 & N/A & N/A & 0 & 0 & 0 & 2 \\
\hline $1 / 3 / 08$ & 0 & 0 & N/A & N/A & 0 & 0 & N/A & N/A & 0.05 & 0 & 0 & 3 \\
\hline $1 / 4 / 08$ & 0 & 0 & N/A & N/A & 0 & 0 & N/A & N/A & 0 & 0 & 0 & 4 \\
\hline $1 / 5 / 08$ & 10.11 & 11.86 & N/A & N/A & 54.46 & 15.24 & N/A & N/A & 35.86 & 7.49 & 7.67 & 5 \\
\hline $1 / 6 / 08$ & 4.32 & 4.67 & N/A & N/A & 8.18 & 6.76 & N/A & N/A & 7.19 & 6.45 & 1.45 & 6 \\
\hline $1 / 7 / 08$ & 3.58 & 3.86 & N/A & N/A & 12.57 & 15.16 & N/A & N/A & 4.85 & 8.15 & 8.56 & 7 \\
\hline $1 / 8 / 08$ & 0 & 0 & N/A & N/A & 0 & 0 & N/A & 0.03 & 0 & 0 & 0 & 8 \\
\hline $1 / 9 / 08$ & 0 & 0 & N/A & N/A & 0.03 & 0.20 & N/A & 0.20 & 0.23 & 0 & 0 & 9 \\
\hline $1 / 10 / 08$ & 0 & 0 & N/A & N/A & 0 & 0 & N/A & 0 & 0 & 0 & 0 & 10 \\
\hline $1 / 11 / 08$ & 0 & 0 & N/A & N/A & 0 & 0 & N/A & 0 & 0 & 0 & 0 & 11 \\
\hline $1 / 12 / 08$ & 0 & 0 & N/A & N/A & 0 & 0 & N/A & 0 & 0 & 0 & 0 & 12 \\
\hline $1 / 13 / 08$ & 0 & 0 & N/A & N/A & 0 & 0 & N/A & 0 & 0 & 0 & 0 & 13 \\
\hline $1 / 14 / 08$ & 0 & 0 & N/A & N/A & 0 & 0 & N/A & 0 & 0 & 0 & 0 & 14 \\
\hline $1 / 15 / 08$ & 0 & 0 & N/A & N/A & 0 & 0 & N/A & 0 & 0 & 0 & 0 & 15 \\
\hline $1 / 16 / 08$ & 0 & 0 & N/A & N/A & 0 & 0 & N/A & 0 & 0 & 0 & 0 & 16 \\
\hline $1 / 17 / 08$ & 0 & 0 & N/A & N/A & 0 & 0 & N/A & 0 & 0 & 0 & 0 & 17 \\
\hline $1 / 18 / 08$ & 0 & 0 & N/A & N/A & 0 & 0 & N/A & 0 & 0 & 0 & 0 & 18 \\
\hline $1 / 19 / 08$ & 0 & 0 & N/A & N/A & 0 & 0 & N/A & 0 & 0 & 0 & 0 & 19 \\
\hline $1 / 20 / 08$ & 0 & 0 & N/A & N/A & 0 & 0 & N/A & 0 & 0 & 0 & 0 & 20 \\
\hline $1 / 21 / 08$ & 0 & 0 & N/A & N/A & 0 & 0 & N/A & 0 & 0 & 0 & 0 & 21 \\
\hline $1 / 22 / 08$ & 0 & 0 & N/A & N/A & 0 & 0 & N/A & 0 & 0 & 0 & 0 & 22 \\
\hline $1 / 23 / 08$ & 0 & 0 & N/A & N/A & 0 & 0 & N/A & 0 & 0 & 0 & 0 & 23 \\
\hline $1 / 24 / 08$ & 0.33 & 0.25 & N/A & N/A & 1.32 & 0.46 & N/A & 0.33 & 2.39 & 1.42 & 1.22 & 24 \\
\hline $1 / 25 / 08$ & 0 & 0 & N/A & N/A & 0 & 0 & N/A & 0 & 0 & 0 & 0 & 25 \\
\hline $1 / 26 / 08$ & 0 & 0 & N/A & N/A & 0 & 0 & N/A & 0 & 0 & 0 & 0 & 26 \\
\hline $1 / 27 / 08$ & 1.68 & 1.88 & N/A & N/A & 4.50 & 3.38 & N/A & 4.32 & 13.23 & 15.34 & 11.07 & 27 \\
\hline $1 / 28 / 08$ & 4.60 & 4.47 & N/A & N/A & 6.65 & 4.95 & N/A & 8.92 & 7.06 & 8.15 & 6.32 & 28 \\
\hline $1 / 29 / 08$ & 0 & 0 & N/A & N/A & 0 & 0 & N/A & 0 & 0 & 0 & 0 & 29 \\
\hline $1 / 30 / 08$ & 0.03 & 0.03 & N/A & N/A & 0.03 & 0.08 & N/A & 0.20 & 0 & 0 & 0.03 & 30 \\
\hline
\end{tabular}


Table 2. Total rainfall, in $\mathrm{mm}$, recorded daily at each of the weather stations. N/A indicates that the station did not collect data that day. - Continued

\begin{tabular}{|c|c|c|c|c|c|c|c|c|c|c|c|c|}
\hline Date & AZ C:05:0031 L & AZ C:05:0031 U & AZ C:13:0365 L & AZ C:13:0365 U & AZ C:13:0006 & AZ C:13:0336 U & AZ C:13:0346 L & AZ C:13:0346 U & AZ B:11:0281 & AZ A:15:0033 & AZ G:03:0072 U & $\begin{array}{l}\text { Year } \\
\text { Day }\end{array}$ \\
\hline $2 / 1 / 08$ & 0 & 0 & N/A & N/A & 0 & 0 & N/A & 0 & 0 & 0 & 0 & 32 \\
\hline $2 / 2 / 08$ & 0 & 0 & N/A & N/A & 0 & 0 & N/A & 0.03 & 0 & 0 & 0 & 33 \\
\hline $2 / 3 / 08$ & 3.81 & 4.34 & N/A & N/A & 28.98 & 13.61 & N/A & 18.92 & 12.12 & 8.41 & 6.83 & 34 \\
\hline $2 / 4 / 08$ & 0 & 0 & N/A & N/A & 0 & 0 & N/A & 0 & 0 & 0.03 & 0.25 & 35 \\
\hline $2 / 5 / 08$ & 0 & 0 & N/A & N/A & 0 & 0 & N/A & 0 & 0 & 0 & 0 & 36 \\
\hline $2 / 6 / 08$ & 0 & 0 & N/A & N/A & 0 & 0 & N/A & 0 & 0 & 0 & 0 & 37 \\
\hline $2 / 7 / 08$ & 0 & 0 & N/A & N/A & 0 & 0 & N/A & 0 & 0 & 0 & 0 & 38 \\
\hline $2 / 8 / 08$ & 0 & 0 & N/A & N/A & 0 & 0 & N/A & 0 & 0 & 0 & 0 & 39 \\
\hline 2/9/08 & 0 & 0 & 0 & 0 & 0 & 0 & N/A & 0 & 0 & 0 & 0 & 40 \\
\hline $2 / 10 / 08$ & 0 & 0 & 0 & 0 & 0 & 0 & 0 & 0 & 0 & 0 & 0 & 41 \\
\hline $2 / 11 / 08$ & 0 & 0 & 0 & 0 & 0 & 0 & 0 & 0 & 0 & 0 & 0 & 42 \\
\hline $2 / 12 / 08$ & 0 & 0 & 0 & 0 & 0 & 0 & 0 & 0 & 0 & 0 & 0 & 43 \\
\hline $2 / 13 / 08$ & 3.20 & 2.67 & 4.62 & 5.31 & 4.45 & 3.68 & 3.73 & 4.24 & 5.92 & 0.30 & 0 & 44 \\
\hline $2 / 14 / 08$ & 0 & 0 & 0 & 0.03 & 0.13 & 0.15 & 0.10 & 0.13 & 0 & 0 & 0 & 45 \\
\hline $2 / 15 / 08$ & 0 & 0 & 0 & 0 & 0 & 0 & 0.03 & 0 & 0 & 0 & 0 & 46 \\
\hline $2 / 16 / 08$ & 0 & 0 & 0 & 0 & 0 & 0 & 0 & 0 & 0 & 0 & 0 & 47 \\
\hline $2 / 17 / 08$ & 0 & 0 & 0 & 0 & 0 & 0 & 0 & 0 & 0 & 0 & 0 & 48 \\
\hline $2 / 18 / 08$ & 0 & 0 & 0 & 0 & 0 & 0 & 0 & 0 & 0 & 0 & 0 & 49 \\
\hline $2 / 19 / 08$ & 0 & 0 & 0 & 0 & 0 & 0 & 0 & 0 & 0 & 0 & 0 & 50 \\
\hline $2 / 20 / 08$ & 9.19 & 9.88 & 4.47 & 4.42 & 4.98 & 7.37 & 6.63 & 7.54 & 0.81 & 0.05 & 4.85 & 51 \\
\hline $2 / 21 / 08$ & 0.03 & 0 & 0 & 0 & 0 & 0 & 0 & 0 & 0 & 0.30 & 0 & 52 \\
\hline $2 / 22 / 08$ & 0.23 & 0.28 & 14.78 & 14.76 & 21.44 & 16.46 & 12.67 & 13.49 & 11.53 & 18.47 & 15.39 & 53 \\
\hline $2 / 23 / 08$ & 0.03 & 0.03 & 0.94 & 1.04 & 1.04 & 0.81 & 0.53 & 0.56 & 0.58 & 0 & 1.19 & 54 \\
\hline $2 / 24 / 08$ & 1.32 & 1.42 & 3.56 & 3.81 & 2.97 & 0.36 & 0.20 & 0.20 & 2.51 & 0 & 0 & 55 \\
\hline $2 / 25 / 08$ & 0 & 0 & 0 & 0.03 & 0.03 & 0 & 0 & 0 & 0 & 0 & 0 & 56 \\
\hline $2 / 26 / 08$ & 0 & 0 & 0 & 0 & 0 & 0 & 0 & 0 & 0 & 0 & 0 & 57 \\
\hline $2 / 27 / 08$ & 0 & 0 & 0 & 0 & 0 & 0 & 0 & 0 & 0 & 0 & 0 & 58 \\
\hline $2 / 28 / 08$ & 0 & 0 & 0 & 0 & 0 & 0 & 0 & 0 & 0 & 0 & 0 & 59 \\
\hline $2 / 29 / 08$ & 0 & 0 & 0 & 0 & 0 & 0 & 0 & 0 & 0 & 0 & 0 & 60 \\
\hline
\end{tabular}


Table 2. Total rainfall, in $\mathrm{mm}$, recorded daily at each of the weather stations. N/A indicates that the station did not collect data that day.-Continued

\begin{tabular}{|c|c|c|c|c|c|c|c|c|c|c|c|c|}
\hline Date & AZ C:05:0031 L & AZ C:05:0031 U & AZ C:13:0365 L & AZ C:13:0365 U & AZ C:13:0006 & AZ C:13:0336 U & AZ C:13:0346 L & AZ C:13:0346 U & AZ B:11:0281 & AZ A:15:0033 & AZ G:03:0072 U & $\begin{array}{l}\text { Year } \\
\text { Day }\end{array}$ \\
\hline $3 / 1 / 08$ & 0 & 0 & 0 & 0 & 0 & 0 & 0 & 0 & 0 & 0 & 0 & 61 \\
\hline $3 / 2 / 08$ & 0 & 0 & 0 & 0.03 & 0 & 0 & 0 & 0 & 0 & 0 & 0 & 62 \\
\hline $3 / 3 / 08$ & 0 & 0 & 0 & 0 & 0 & 0 & 0 & 0 & 0.03 & 0 & 0 & 63 \\
\hline $3 / 4 / 08$ & 0 & 0 & 0 & 0 & 0 & 0 & 0 & 0 & 0 & 0 & 0 & 64 \\
\hline $3 / 5 / 08$ & 0 & 0 & 0 & 0 & 0 & 0 & 0 & 0 & 0 & 0 & 0 & 65 \\
\hline $3 / 6 / 08$ & 0 & 0 & 0 & 0 & 0 & 0 & 0 & 0 & 0 & 0 & 0 & 66 \\
\hline $3 / 7 / 08$ & 0 & 0 & 0 & 0 & 0 & 0 & 0 & 0 & 0 & 0 & 0 & 67 \\
\hline $3 / 8 / 08$ & 0 & 0 & 0 & 0 & 0 & 0 & 0 & 0 & 0 & 0 & 0 & 68 \\
\hline $3 / 9 / 08$ & 0 & 0 & 0 & 0 & 0 & 0 & 0 & 0 & 0 & 0 & 0 & 69 \\
\hline $3 / 10 / 08$ & 0 & 0 & 0 & 0 & 0 & 0 & 0 & 0 & 0 & 0 & 0 & 70 \\
\hline $3 / 11 / 08$ & 0 & 0.03 & 0 & 0 & 0 & 0 & 0 & 0 & 0 & 0 & 0 & 71 \\
\hline $3 / 12 / 08$ & 0 & 0 & 0 & 0 & 0 & 0 & 0 & 0 & 0 & 0 & 0 & 72 \\
\hline $3 / 13 / 08$ & 0 & 0 & 0 & 0 & 0 & 0 & 0 & 0 & 0 & 0 & 0 & 73 \\
\hline $3 / 14 / 08$ & 0 & 0 & 0 & 0 & 0 & 0 & 0 & 0 & 0 & 0 & 0 & 74 \\
\hline $3 / 15 / 08$ & 0 & 0 & 0 & 0.03 & 0 & 0 & 0 & 0 & 0 & 0.03 & 0.05 & 75 \\
\hline $3 / 16 / 08$ & 1.35 & 1.52 & 3.71 & 3.58 & 1.45 & 0.30 & 0.15 & 0.13 & 1.57 & 9.86 & 3.96 & 76 \\
\hline $3 / 17 / 08$ & 1.37 & 1.52 & 2.03 & 2.44 & 2.11 & 2.13 & 2.21 & 2.21 & 0 & 0 & 0 & 77 \\
\hline $3 / 18 / 08$ & 0 & 0 & 0 & 0 & 0 & 0 & 0 & 0 & 0 & 0 & 0 & 78 \\
\hline $3 / 19 / 08$ & 0 & 0 & 0 & 0 & 0 & 0 & 0 & 0 & 0 & 0 & 0 & 79 \\
\hline $3 / 20 / 08$ & 0 & 0 & 0 & 0.05 & 0 & 0 & 0 & N/A & 0 & 0 & 0 & 80 \\
\hline $3 / 21 / 08$ & 0 & 0 & 0 & 0 & 0 & 0 & 0 & N/A & 0 & 0 & 0 & 81 \\
\hline $3 / 22 / 08$ & 0 & 0 & 0 & 0 & 0 & 0 & 0 & N/A & 0 & 0 & 0 & 82 \\
\hline $3 / 23 / 08$ & 0 & 0 & 0 & 0 & 0 & 0 & 0 & N/A & 0 & 0 & 0 & 83 \\
\hline $3 / 24 / 08$ & 0 & 0 & 0 & 0 & 0 & 0 & 0 & N/A & 0 & 0 & 0 & 84 \\
\hline $3 / 25 / 08$ & 0 & 0 & 0 & 0 & 0 & 0 & 0 & N/A & 0 & 0 & 0 & 85 \\
\hline $3 / 26 / 08$ & 0 & 0 & 0 & 0.05 & 0 & 0 & 0 & N/A & 0 & 0 & 0 & 86 \\
\hline $3 / 27 / 08$ & 0 & 0 & 0 & 0 & 0 & 0 & 0 & N/A & 0 & 0 & 0 & 87 \\
\hline $3 / 28 / 08$ & 0 & 0 & 0 & 0.03 & 0 & 0 & 0 & N/A & 0 & 0 & 0 & 88 \\
\hline $3 / 29 / 08$ & 0.05 & 0 & 0 & 0.13 & 0 & 0 & 0 & N/A & 0 & 0 & 0 & 89 \\
\hline $3 / 30 / 08$ & 0.36 & 0.41 & 0.58 & 0.81 & 0.43 & 0.97 & 0.91 & N/A & 0.03 & 0.03 & 0 & 90 \\
\hline $3 / 31 / 08$ & 0 & 0 & 0 & 0 & 0 & 0 & 0 & N/A & 0 & 0 & 0 & 91 \\
\hline
\end{tabular}


Table 2. Total rainfall, in $\mathrm{mm}$, recorded daily at each of the weather stations. N/A indicates that the station did not collect data that day.-Continued

\begin{tabular}{|c|c|c|c|c|c|c|c|c|c|c|c|c|}
\hline Date & AZ C:05:0031 L & AZ C:05:0031 U & AZ C:13:0365 L & AZ C:13:0365 U & AZ C:13:0006 & AZ C:13:0336 U & AZ C:13:0346 L & AZ C:13:0346 U & AZ B:11:0281 & AZ A:15:0033 & AZ G:03:0072 U & $\begin{array}{l}\text { Year } \\
\text { Day }\end{array}$ \\
\hline $4 / 1 / 08$ & 0 & 0 & 0 & 0 & 0 & 0 & 0 & N/A & 0 & 0 & 0 & 92 \\
\hline $4 / 2 / 08$ & 0.03 & 0.03 & 0 & 0.30 & 0 & 0 & 0 & N/A & 0 & 0 & 0 & 93 \\
\hline $4 / 3 / 08$ & 0.03 & 0 & 0.03 & 0.03 & 0.03 & 0 & 0 & N/A & 0 & 0 & 0 & 94 \\
\hline $4 / 4 / 08$ & 0 & 0.03 & 0 & 0 & 0 & 0 & 0 & N/A & 0 & 0 & 0 & 95 \\
\hline $4 / 5 / 08$ & 0 & 0 & 0 & 0.08 & 0 & 0 & 0 & 0 & 0 & 0 & 0 & 96 \\
\hline $4 / 6 / 08$ & 0 & 0 & 0 & 0.23 & 0 & 0 & 0.03 & 0.03 & 0 & 0 & 0 & 97 \\
\hline $4 / 7 / 08$ & 0 & 0 & 0 & 0 & 0 & 0.03 & 0 & 0 & 0 & 0 & 0 & 98 \\
\hline $4 / 8 / 08$ & 0 & 0 & 0 & 0.30 & 0 & 0 & 0 & 0 & 0 & 0 & 0 & 99 \\
\hline $4 / 9 / 08$ & 0 & 0 & 0.08 & 0.05 & 0.10 & 0.10 & 0.05 & 0.03 & 0.53 & 0 & 0 & 100 \\
\hline $4 / 10 / 08$ & 0.03 & 0 & 0 & 0 & 0 & 0 & 0 & 0 & 0 & 0 & 0 & 101 \\
\hline $4 / 11 / 08$ & 0 & 0.03 & 0 & 0.03 & 0 & 0 & 0 & 0 & 0 & 0 & 0 & 102 \\
\hline $4 / 12 / 08$ & 0 & 0 & 0 & 0 & 0 & 0 & 0 & 0 & 0 & 0 & 0 & 103 \\
\hline $4 / 13 / 08$ & 0 & 0 & 0 & 0 & 0 & 0 & 0 & 0 & 0 & 0 & 0 & 104 \\
\hline $4 / 14 / 08$ & 0 & 0 & 0 & 0.03 & 0 & 0 & 0 & 0 & 0 & 0 & 0 & 105 \\
\hline $4 / 15 / 08$ & 0 & 0 & 0 & 2.84 & 0 & 0.05 & 0 & 0 & 0.23 & 0 & 0 & 106 \\
\hline $4 / 16 / 08$ & 0 & 0 & 0 & 0.08 & 0 & 0 & 0 & 0 & 0 & 0 & 0 & 107 \\
\hline $4 / 17 / 08$ & 0 & 0 & 0 & 0 & 0 & 0 & 0 & 0 & 0 & 0 & 0 & 108 \\
\hline $4 / 18 / 08$ & 0 & 0 & 0 & 0 & 0 & 0 & 0 & 0 & 0 & 0 & 0 & 109 \\
\hline $4 / 19 / 08$ & 0 & 0 & 0 & 0.74 & 0 & 0 & 0 & 0.03 & 0.56 & 0 & 0 & 110 \\
\hline $4 / 20 / 08$ & 0 & 0 & 0 & 0.13 & 0 & 0 & 0.05 & 0 & 0 & 0 & 0 & 111 \\
\hline $4 / 21 / 08$ & 0 & 0 & 0 & 0 & 0 & 0 & 0 & 0 & 0 & 0 & 0 & 112 \\
\hline $4 / 22 / 08$ & 0 & 0 & 0 & 0 & 0 & 0 & 0 & 0 & 0 & 0 & 0 & 113 \\
\hline $4 / 23 / 08$ & 0 & 0 & 0 & 0.05 & 0 & 0 & 0.03 & 0 & 0.03 & 0 & 0 & 114 \\
\hline $4 / 24 / 08$ & 0 & 0 & 0 & 0 & 0 & 0 & 0 & 0 & 0 & 0 & 0 & 115 \\
\hline $4 / 25 / 08$ & 0 & 0 & 0 & 0 & 0 & 0 & 0 & 0 & 0 & 0 & 0 & 116 \\
\hline $4 / 26 / 08$ & 0 & 0 & 0 & 0.03 & 0 & 0 & 0 & 0 & 0 & 0 & 0 & 117 \\
\hline $4 / 27 / 08$ & 0 & 0 & 0 & 0 & 0 & 0 & 0 & 0 & 0 & 0 & 0 & 118 \\
\hline $4 / 28 / 08$ & 0 & 0 & 0 & 0 & 0 & 0 & 0 & 0 & 0 & 0 & 0 & 119 \\
\hline $4 / 29 / 08$ & 0 & 0 & 0 & 1.35 & 0 & 0.03 & 0.05 & 0 & 0.38 & 0 & 0 & 120 \\
\hline $4 / 30 / 08$ & 0 & 0 & 0.03 & 1.70 & 0.05 & 0 & 0.10 & 0 & 0.15 & 0 & 0 & 121 \\
\hline
\end{tabular}


Table 2. Total rainfall, in $\mathrm{mm}$, recorded daily at each of the weather stations. N/A indicates that the station did not collect data that day.-Continued

\begin{tabular}{|c|c|c|c|c|c|c|c|c|c|c|c|c|}
\hline Date & AZ C:05:0031 L & AZ C:05:0031 U & AZ C:13:0365 L & AZ C:13:0365 U & AZ C:13:0006 & AZ C:13:0336 U & AZ C:13:0346 L & AZ C:13:0346 U & AZ B:11:0281 & AZ A:15:0033 & AZ G:03:0072 U & $\begin{array}{l}\text { Year } \\
\text { Day }\end{array}$ \\
\hline $5 / 1 / 08$ & 0 & 0 & 0 & 0 & 0 & 0 & 0 & 0 & 0.03 & 0 & 0 & 122 \\
\hline $5 / 2 / 08$ & 0 & 0 & 0 & 0 & 0 & 0 & 0 & 0 & 0 & 0 & 0 & 123 \\
\hline $5 / 3 / 08$ & 0 & 0 & 0 & 0 & 0 & 0 & 0 & 0 & 0 & 0 & 0 & 124 \\
\hline $5 / 4 / 08$ & 0 & 0 & 0 & 0 & 0 & 0 & 0 & 0 & 0 & 0 & 0 & 125 \\
\hline $5 / 5 / 08$ & 0 & 0 & 0 & 0.03 & 0 & 0 & 0 & 0 & 0 & 0 & 0 & 126 \\
\hline $5 / 6 / 08$ & 0 & 0 & 0.03 & 0 & 0 & 0 & 0 & 0 & 0.18 & 0 & 0 & 127 \\
\hline $5 / 7 / 08$ & 0.03 & 0.08 & 0 & 0.33 & 0 & 0 & 0 & 0 & 0.46 & 0 & 0 & 128 \\
\hline $5 / 8 / 08$ & 0 & 0 & 0 & 0 & 0 & 0 & 0 & 0 & 0.13 & 0 & 0 & 129 \\
\hline $5 / 9 / 08$ & 0.03 & 0 & 0 & 0.41 & 0 & 0 & 0 & 0 & 0 & 0 & 0 & 130 \\
\hline $5 / 10 / 08$ & 0 & 0 & 0 & 0 & 0 & 0 & 0 & 0 & 0 & 0 & 0 & 131 \\
\hline $5 / 11 / 08$ & 0 & 0 & 0 & 0.20 & 0 & 0 & 0 & 0 & 0 & 0 & 0 & 132 \\
\hline $5 / 12 / 08$ & 1.70 & 1.85 & 9.02 & 9.98 & 8.31 & 5.31 & 5.00 & 4.88 & 0.18 & 1.22 & 0.53 & 133 \\
\hline $5 / 13 / 08$ & 0.94 & 1.02 & 13.51 & 13.11 & 13.77 & 10.95 & 12.19 & 12.65 & 0.03 & 1.04 & 0.18 & 134 \\
\hline $5 / 14 / 08$ & 0 & 0 & 0 & 0 & 0 & 0 & 0 & N/A & 0.15 & 0 & 0 & 135 \\
\hline $5 / 15 / 08$ & 0 & 0 & 0 & 0 & 0 & 0 & 0 & N/A & 0.03 & 0 & 0 & 136 \\
\hline $5 / 16 / 08$ & 0 & 0 & 0 & 0 & 0 & 0 & 0 & N/A & 0.05 & 0 & 0 & 137 \\
\hline $5 / 17 / 08$ & 0 & 0 & 0 & 0 & 0 & 0 & 0 & N/A & 0 & 0 & 0 & 138 \\
\hline $5 / 18 / 08$ & 0 & 0 & 0 & 0 & 0 & 0 & 0 & N/A & 0 & 0 & 0 & 139 \\
\hline $5 / 19 / 08$ & 0 & 0 & 0 & 0 & 0 & 0 & 0 & N/A & 0 & 0 & 0 & 140 \\
\hline $5 / 20 / 08$ & 0 & 0 & 0.05 & 0.30 & 0 & 0 & 0 & N/A & 0.10 & 0 & 0 & 141 \\
\hline $5 / 21 / 08$ & 0.56 & 0.53 & 0.30 & 0.79 & 0.25 & 0.18 & 0 & N/A & 0.10 & 0 & 0 & 142 \\
\hline $5 / 22 / 08$ & 0.53 & 0.56 & 0.41 & 0.43 & 0.15 & 0.43 & 1.98 & N/A & 18.77 & 0.18 & 0.05 & 143 \\
\hline $5 / 23 / 08$ & 0.08 & 0.05 & 0.91 & 1.02 & 0.86 & 0.69 & 0.18 & N/A & 4.98 & 6.68 & 2.16 & 144 \\
\hline $5 / 24 / 08$ & 0 & 0 & 0 & 0 & 0 & 0.03 & 0.03 & N/A & 0.48 & 1.32 & 1.09 & 145 \\
\hline $5 / 25 / 08$ & 0 & 0.03 & 0 & 0 & 0 & 0 & 0 & N/A & 0.03 & 0 & 0 & 146 \\
\hline $5 / 26 / 08$ & 0.03 & 0 & 0 & 0 & 0 & 0 & 0 & N/A & 0.08 & 0 & 0 & 147 \\
\hline $5 / 27 / 08$ & 0 & 0 & 0 & 0 & 0 & 0 & 0 & N/A & 0 & 0 & 0 & 148 \\
\hline $5 / 28 / 08$ & 0 & 0 & 0 & 0.41 & 0 & 0 & 0 & N/A & 0.03 & 0 & 0 & 149 \\
\hline $5 / 29 / 08$ & 0 & 0 & 0 & 0.38 & 0 & 0 & 0 & N/A & 0.08 & 0 & 0 & 150 \\
\hline $5 / 30 / 08$ & 0 & 0 & 0 & 0.03 & 0 & 0 & 0 & N/A & 0 & 0 & 0 & 151 \\
\hline $5 / 31 / 08$ & 0 & 0.10 & 0 & 0.15 & 0 & 0 & 0 & N/A & 0 & 0 & 0 & 152 \\
\hline
\end{tabular}


Table 2. Total rainfall, in mm, recorded daily at each of the weather stations. N/A indicates that the station did not collect data that day.-Continued

\begin{tabular}{|c|c|c|c|c|c|c|c|c|c|c|c|c|}
\hline Date & AZ C:05:0031 L & AZ C:05:0031 U & AZ C:13:0365 L & AZ C:13:0365 U & AZ C:13:0006 & AZ C:13:0336 U & AZ C:13:0346 L & AZ C:13:0346 U & AZ B:11:0281 & AZ A:15:0033 & AZ G:03:0072 U & $\begin{array}{l}\text { Yea } \\
\text { Day }\end{array}$ \\
\hline $6 / 1 / 08$ & 0 & 0 & 0 & 0.36 & 0 & 0 & 0 & N/A & 0 & 0 & 0 & 153 \\
\hline $6 / 2 / 08$ & 0 & 0 & 0 & 0.48 & 0 & 0 & 0 & N/A & 0 & 0 & 0 & 154 \\
\hline $6 / 3 / 08$ & 0 & 0 & 0 & 0.28 & 0 & 0 & 0 & N/A & 0 & 0 & 0 & 155 \\
\hline $6 / 4 / 08$ & 1.60 & 1.91 & 7.16 & 8.28 & 9.30 & 4.98 & 5.84 & N/A & 6.93 & 3.99 & 5.16 & 156 \\
\hline $6 / 5 / 08$ & 0.05 & 0.05 & 0 & 0.05 & 0 & 0 & 0 & N/A & 0.05 & 0 & 0 & 157 \\
\hline $6 / 6 / 08$ & 0 & 0 & 0 & 0.13 & 0 & 0 & 0 & N/A & 0 & 0 & 0 & 158 \\
\hline $6 / 7 / 08$ & 0 & 0 & 0.03 & 1.52 & 0 & 0 & 0 & N/A & 0 & 0 & 0 & 159 \\
\hline $6 / 8 / 08$ & 0 & 0 & 0 & 0.05 & 0 & 0 & 0 & N/A & 0 & 0 & 0 & 160 \\
\hline $6 / 9 / 08$ & 0 & 0 & 0 & 0 & 0 & 0 & 0 & N/A & 0 & 0 & 0 & 161 \\
\hline $6 / 10 / 08$ & 0 & 0 & 0 & 0.28 & 0 & 0 & 0 & N/A & 0 & 0 & 0 & 162 \\
\hline $6 / 11 / 08$ & 0 & 0 & 0.05 & 0.03 & 0 & 0 & 0 & N/A & 0 & 0 & 0 & 163 \\
\hline $6 / 12 / 08$ & 0 & 0 & 0 & 0 & 0 & 0 & 0 & N/A & 0 & 0 & 0 & 164 \\
\hline $6 / 13 / 08$ & 0 & 0 & 0 & 0 & 0 & 0 & 0 & N/A & 0.05 & 0 & 0 & 165 \\
\hline $6 / 14 / 08$ & 0 & 0 & 0 & 0 & 0 & 0 & 0 & N/A & 0.03 & 0 & 0 & 166 \\
\hline $6 / 15 / 08$ & 0 & 0 & 0 & 0 & 0 & 0 & 0 & N/A & 0 & 0 & 0 & 167 \\
\hline $6 / 16 / 08$ & 0 & 0 & 0 & 0 & 0 & 0 & 0 & N/A & 0 & 0 & 0 & 168 \\
\hline $6 / 17 / 08$ & 0 & 0 & 0 & 0 & 0 & 0 & 0 & N/A & 0 & 0 & 0 & 169 \\
\hline $6 / 18 / 08$ & 0 & 0 & 0 & 0 & 0 & 0 & 0 & N/A & 0 & 0 & 0 & 170 \\
\hline $6 / 19 / 08$ & 0 & 0 & 0 & 0 & 0 & 0 & 0 & N/A & 0 & 0 & 0 & 171 \\
\hline $6 / 20 / 08$ & 0.03 & 0 & 0 & 0 & 0 & 0 & 0 & N/A & 0 & 0 & 0 & 172 \\
\hline $6 / 21 / 08$ & 0 & 0 & 0 & 0 & 0 & 0 & 0 & N/A & 0 & 0 & 0 & 173 \\
\hline $6 / 22 / 08$ & 0 & 0 & 0 & 0 & 0 & 0 & 0 & N/A & 0 & 0 & 0 & 174 \\
\hline $6 / 23 / 08$ & 0 & 0 & 0 & 0 & 0 & 0 & 0 & N/A & 0 & 0 & 0 & 175 \\
\hline $6 / 24 / 08$ & 0 & 0 & 0 & 0 & 0 & 0 & 0 & N/A & 0 & 0 & 0 & 176 \\
\hline $6 / 25 / 08$ & 0 & 0 & 0 & 0 & 0 & 0 & 0 & N/A & 0.03 & 0 & 0 & 177 \\
\hline $6 / 26 / 08$ & 0 & 0 & 0 & 0 & 0 & 0 & 0 & N/A & 0 & 0 & 0 & 178 \\
\hline $6 / 27 / 08$ & 0 & 0 & 0 & 0 & 0 & 0 & 0 & N/A & 0 & 0 & 0 & 179 \\
\hline $6 / 28 / 08$ & 0 & 0 & 0 & 0 & 0 & 0 & 0 & N/A & 0 & 0 & 0 & 180 \\
\hline $6 / 29 / 08$ & 0.03 & 0.03 & 0 & 0.03 & 0 & 0 & 0 & N/A & 0 & 0 & 0.03 & 181 \\
\hline $6 / 30 / 08$ & 0 & 0 & 0 & 0 & 0 & 0 & 0 & N/A & 0 & 0 & 0 & 182 \\
\hline
\end{tabular}


Table 2. Total rainfall, in $\mathrm{mm}$, recorded daily at each of the weather stations. N/A indicates that the station did not collect data that day.-Continued

\begin{tabular}{|c|c|c|c|c|c|c|c|c|c|c|c|c|}
\hline Date & AZ C:05:0031 L & AZ C:05:0031 U & AZ C:13:0365 L & AZ C:13:0365 U & AZ C:13:0006 & AZ C:13:0336 U & AZ C:13:0346 L & AZ C:13:0346 U & AZ B:11:0281 & AZ A:15:0033 & AZ G:03:0072 U & $\begin{array}{l}\text { Year } \\
\text { Day }\end{array}$ \\
\hline 7/1/08 & 0 & 0 & 2.13 & 2.51 & 1.63 & 0.03 & 0.08 & N/A & 0.36 & 0 & 0 & 183 \\
\hline $7 / 2 / 08$ & 0 & 0 & 0 & 0 & 0 & 0 & 0 & N/A & 0 & 0 & 0 & 184 \\
\hline $7 / 3 / 08$ & 0 & 0 & 0 & 0 & 0 & 0 & 0 & N/A & 0 & 0 & 0 & 185 \\
\hline $7 / 4 / 08$ & 0 & 0 & 0 & 0 & 0 & 0 & 0 & N/A & 0.66 & 0 & 0.05 & 186 \\
\hline $7 / 5 / 08$ & 1.02 & 0.89 & 0.64 & 0.69 & 0.05 & 0.30 & 0.10 & N/A & 0.18 & 0.03 & 2.11 & 187 \\
\hline $7 / 6 / 08$ & 6.43 & 6.96 & 11.28 & 11.81 & 22.66 & 0.66 & 1.17 & N/A & 8.86 & 0.41 & 5.56 & 188 \\
\hline 7/7/08 & 0 & 0 & 0 & 0 & 0 & 0 & 0 & N/A & 0 & 0 & 0 & 189 \\
\hline 7/8/08 & 0 & 0 & 0 & 0 & 0 & 0 & 0 & N/A & 0 & 0 & 0 & 190 \\
\hline 7/9/08 & 0 & 0 & 0 & 0 & 0 & 0 & 0 & N/A & 0.03 & 0 & 0 & 191 \\
\hline $7 / 10 / 08$ & 0 & 0 & 0 & 0.08 & 0 & 0 & 0 & N/A & 0.03 & 0 & 7.29 & 192 \\
\hline 7/11/08 & 0 & 0 & 0 & 0 & 0.03 & 0 & 0 & N/A & 0 & 0 & 0 & 193 \\
\hline $7 / 12 / 08$ & 0.03 & 0.03 & 13.08 & 12.12 & 3.18 & 7.04 & 8.66 & N/A & 0 & 15.49 & 0.05 & 194 \\
\hline 7/13/08 & 6.15 & 6.96 & 10.82 & 12.09 & 0.94 & 0 & 0.05 & N/A & 2.44 & 0 & 0 & 195 \\
\hline $7 / 14 / 08$ & 0.03 & 0.03 & 0.81 & 0.94 & 0.05 & 4.09 & 15.24 & N/A & 0.97 & 0.38 & 16.51 & 196 \\
\hline $7 / 15 / 08$ & 7.01 & 5.92 & 0 & 0 & 0 & 0 & 0 & N/A & 0.03 & 0 & 0.05 & 197 \\
\hline 7/16/08 & 0 & 0 & 0 & 0 & 0 & 0 & 0 & N/A & 0 & 0 & 0.03 & 198 \\
\hline 7/17/08 & 0 & 0 & 0 & 0 & 0 & 0 & 0 & N/A & 0.36 & 0 & 0.28 & 199 \\
\hline 7/18/08 & 4.11 & 4.01 & 0 & 0 & 0 & 0 & 0 & N/A & 0 & 0 & 0 & 200 \\
\hline 7/19/08 & 0.05 & 0.08 & 0 & 0 & 0 & 0 & 0.03 & N/A & 0 & 0.03 & 0 & 201 \\
\hline $7 / 20 / 08$ & 1.37 & 1.27 & 0.15 & 0.13 & 0.03 & 0.66 & 3.51 & N/A & 0.10 & 0.20 & 0.48 & 202 \\
\hline $7 / 21 / 08$ & 0 & 0 & 0.84 & 0.64 & 21.72 & 0.41 & 0 & N/A & 0 & 0 & 0 & 203 \\
\hline $7 / 22 / 08$ & 0 & 0 & 0 & 0 & 0 & 0 & 0 & N/A & 0 & 0 & 0 & 204 \\
\hline $7 / 23 / 08$ & 0 & 0 & 0 & 0 & 0 & 0 & 0 & N/A & 0 & 0 & 0 & 205 \\
\hline $7 / 24 / 08$ & 0 & 0 & 0 & 0.03 & 0 & 0.43 & 5.41 & N/A & 0 & 0 & 0 & 206 \\
\hline $7 / 25 / 08$ & 0.74 & 0.89 & 0 & 0.03 & 0.38 & 0.53 & 1.65 & N/A & 0 & 0.08 & 0.03 & 207 \\
\hline $7 / 26 / 08$ & 0.18 & 0.23 & 0.30 & 0.25 & 0 & 0.66 & 1.07 & N/A & 0.18 & 0.25 & 0.18 & 208 \\
\hline $7 / 27 / 08$ & 1.24 & 1.14 & 4.65 & 4.80 & 0 & 0 & 0 & N/A & 0 & 0 & 0 & 209 \\
\hline $7 / 28 / 08$ & 0 & 0 & 3.20 & 3.56 & 2.97 & 0.03 & 0.10 & N/A & 0.05 & 0 & 0 & 210 \\
\hline $7 / 29 / 08$ & 0 & 0 & 0 & 0 & 0 & 0 & 0 & N/A & 0 & 0 & 0 & 211 \\
\hline 7/30/08 & 0 & 0 & 0 & 0 & 0 & 0 & 0 & 0 & 0 & 0 & 0 & 212 \\
\hline $7 / 31 / 08$ & 0 & 0 & 0 & 0 & 0 & 0 & 0 & 0 & 0 & 0 & 0 & 213 \\
\hline
\end{tabular}


Table 2. Total rainfall, in $\mathrm{mm}$, recorded daily at each of the weather stations. N/A indicates that the station did not collect data that day.-Continued

\begin{tabular}{|c|c|c|c|c|c|c|c|c|c|c|c|c|}
\hline Date & AZ C:05:0031 L & AZ C:05:0031 U & AZ C:13:0365 L & AZ C:13:0365 U & AZ C:13:0006 & AZ C:13:0336 U & AZ C:13:0346 L & AZ C:13:0346 U & AZ B:11:0281 & AZ A:15:0033 & AZ G:03:0072 U & $\begin{array}{l}\text { Yea } \\
\text { Day }\end{array}$ \\
\hline $8 / 1 / 08$ & 0 & 0 & 0 & 0 & 0 & 0 & 0 & 0.03 & 0 & 0 & 0 & 214 \\
\hline $8 / 2 / 08$ & 0.20 & 0.41 & 0 & 0 & 0 & 0 & 0 & 0 & 0 & 0 & 0 & 215 \\
\hline $8 / 3 / 08$ & 6.81 & 5.99 & 0 & 0 & 0 & 0 & 0 & 0 & 0 & 11.63 & 0.25 & 216 \\
\hline $8 / 4 / 08$ & 0.03 & 0.03 & 0.03 & 0.05 & 0 & 0 & 0 & 0.03 & 1.37 & 1.57 & 0.63 & 217 \\
\hline $8 / 5 / 08$ & 0.03 & 0.08 & 0 & 0 & 0 & 0 & 0 & 0 & 0 & 1.02 & 0.15 & 218 \\
\hline $8 / 6 / 08$ & 0.05 & 0 & 1.32 & 1.40 & 6.81 & 0.28 & 0.33 & 0.36 & 0.51 & 5.49 & 11.40 & 219 \\
\hline $8 / 7 / 08$ & 1.57 & 1.22 & 0 & 0 & 0 & 0 & 0 & 0 & 0.18 & 5.03 & 1.52 & 220 \\
\hline $8 / 8 / 08$ & 1.65 & 1.55 & 48.13 & 51.61 & 8.28 & 13.39 & 28.30 & 26.87 & 0.58 & 0.20 & 0.05 & 221 \\
\hline $8 / 9 / 08$ & 0.30 & 0.28 & 0.38 & 0.36 & 0 & 0 & 3.76 & 4.04 & 0 & 0.03 & 0 & 222 \\
\hline $8 / 10 / 08$ & 0 & 0 & 0 & 0 & 0 & 0 & 0 & 0 & 0 & 0 & 0 & 223 \\
\hline $8 / 11 / 08$ & 0 & 0 & 0 & 0 & 0 & 0 & 0 & 0 & 0 & 0 & 0 & 224 \\
\hline $8 / 12 / 08$ & 0 & 0 & 0 & 0 & 0 & 0 & 0 & 0 & 0 & 0 & 0 & 225 \\
\hline $8 / 13 / 08$ & 0 & 0 & 0 & 0 & 0 & 0.05 & 0.03 & 0.03 & 0 & 0 & 0 & 226 \\
\hline $8 / 14 / 08$ & 0 & 0 & 0 & 0 & 0 & 0 & 0 & 0 & 0 & 0 & 0 & 227 \\
\hline $8 / 15 / 08$ & 2.21 & 1.55 & 0.71 & 0.69 & 0.51 & 2.29 & 4.75 & 6.15 & 0.23 & 0 & 0 & 228 \\
\hline 8/16/08 & 5.41 & 5.13 & 9.37 & 8.94 & 5.28 & 8.53 & 8.26 & 8.31 & 22.25 & 0.51 & 2.13 & 229 \\
\hline $8 / 17 / 08$ & 2.21 & 2.13 & 3.20 & 3.38 & 1.78 & 0 & 0 & 0 & 0 & 0 & 0.05 & 230 \\
\hline $8 / 18 / 08$ & 17.48 & 16.87 & 3.71 & 4.88 & 1.04 & 27.76 & 2.08 & 2.03 & 0 & 0 & 0 & 231 \\
\hline $8 / 19 / 08$ & 0 & 0 & 0 & 0 & 0 & 0 & 0 & 0 & 0 & 0 & 0 & 232 \\
\hline $8 / 20 / 08$ & 0 & 0 & 0 & 0 & 0 & 0 & 0 & 0 & 0 & 0 & 0 & 233 \\
\hline $8 / 21 / 08$ & 0 & 0 & 0 & 0 & 0 & 0 & 0 & 0 & 0 & 0 & 0 & 234 \\
\hline $8 / 22 / 08$ & 0 & 0 & 0 & 0 & 0 & 0 & 0 & 0 & 0 & 0 & 0 & 235 \\
\hline $8 / 23 / 08$ & 0 & 0 & 0 & 0 & 0 & 0 & 0 & 0 & 0 & 0 & 0 & 236 \\
\hline $8 / 24 / 08$ & 0 & 0 & 0.05 & 0.08 & 0 & 0 & 0 & 0 & 0 & 0 & 0.05 & 237 \\
\hline $8 / 25 / 08$ & 0.03 & 0.03 & 0.30 & 0.41 & 0.30 & 0.23 & 0.25 & 0.25 & 0.05 & 0 & 0.03 & 238 \\
\hline $8 / 26 / 08$ & 0 & 0 & 0 & 0 & 0 & 0 & 0 & 0 & 0 & 0 & 0 & 239 \\
\hline $8 / 27 / 08$ & 0 & 0 & 0.03 & 0 & 0 & 0 & 0 & 0 & 0 & 0 & 0 & 240 \\
\hline $8 / 28 / 08$ & 0 & 0 & 0 & 0 & 0 & 0 & 0 & 0 & 0 & 0 & 0 & 241 \\
\hline $8 / 29 / 08$ & 0 & 0 & 0 & 0 & 0 & 0 & 0 & 0 & 0 & 0 & 0 & 242 \\
\hline 8/30/08 & 2.36 & 2.72 & 2.69 & 2.77 & 4.78 & 0.15 & 0.51 & 0.76 & 0.13 & 10.29 & 11.56 & 243 \\
\hline $8 / 31 / 08$ & 19.13 & 20.37 & 19.20 & 20.09 & 8.43 & 4.98 & 5.00 & 5.74 & 33.71 & 10.54 & 14.94 & 244 \\
\hline
\end{tabular}


Table 2. Total rainfall, in $\mathrm{mm}$, recorded daily at each of the weather stations. N/A indicates that the station did not collect data that day.-Continued

\begin{tabular}{|c|c|c|c|c|c|c|c|c|c|c|c|c|}
\hline Date & AZ C:05:0031 L & AZ C:05:0031 U & AZ C:13:0365 L & AZ C:13:0365 U & AZ C:13:0006 & AZ C:13:0336 U & AZ C:13:0346 L & AZ C:13:0346 U & AZ B:11:0281 & AZ A:15:0033 & AZ G:03:0072 U & $\begin{array}{l}\text { Year } \\
\text { Day }\end{array}$ \\
\hline $9 / 1 / 08$ & 0 & 0 & 0 & 0 & 0 & 0 & 0 & 0 & 0 & 0.08 & 0 & 245 \\
\hline $9 / 2 / 08$ & 0 & 0 & 0 & 0 & 0 & 0 & 0 & 0 & 0 & 0 & 0 & 246 \\
\hline $9 / 3 / 08$ & 0 & 0 & 0 & 0 & 0 & 0 & 0 & 0 & 0 & 0 & 0 & 247 \\
\hline $9 / 4 / 08$ & 0 & 0 & 0 & 0 & 0 & 0 & 0 & 0 & 0 & 0 & 0 & 248 \\
\hline $9 / 5 / 08$ & 0 & 0 & 0 & 0 & 0 & 0 & 0 & 0 & 0 & 0 & 0 & 249 \\
\hline $9 / 6 / 08$ & 0 & 0 & 0 & 0 & 0 & 0 & 0 & N/A & 0 & 0 & 0 & 250 \\
\hline $9 / 7 / 08$ & 0 & 0 & 0 & 0 & 0 & 0 & 0 & N/A & 0 & 0 & 0 & 251 \\
\hline $9 / 8 / 08$ & 0 & 0 & 0 & 0.03 & 0 & 0 & 0 & N/A & 0.03 & 0 & 0.48 & 252 \\
\hline 9/9/08 & 0.13 & 0.20 & 0 & 0.03 & 0.10 & 0 & 0.03 & N/A & 0.05 & 0 & 0 & 253 \\
\hline 9/10/08 & 9.80 & 9.19 & 0.46 & 0.38 & 0.08 & 1.88 & 5.49 & N/A & 0.69 & 0 & 0 & 254 \\
\hline 9/11/08 & 0 & 0 & 0 & 0 & 0 & 0 & 0 & N/A & 0 & 0 & 0 & 255 \\
\hline $9 / 12 / 08$ & 0 & 0 & 0 & 0 & 0 & 0 & 0 & N/A & 0 & 0 & 0 & 256 \\
\hline $9 / 13 / 08$ & 0 & 0 & 0 & 0 & 0 & 0 & 0 & N/A & 0 & 0 & 0 & 257 \\
\hline $9 / 14 / 08$ & 0 & 0 & 0 & 0 & 0 & 0 & 0 & N/A & 0 & 0 & 0 & 258 \\
\hline $9 / 15 / 08$ & 0 & 0 & 0 & 0 & 0 & 0 & 0 & N/A & 0 & 0 & 0 & 259 \\
\hline $9 / 16 / 08$ & 0.03 & 0.03 & 0.08 & 0.18 & 0.03 & 0 & 0.33 & N/A & 0.05 & 0.20 & 0.18 & 260 \\
\hline $9 / 17 / 08$ & 0.03 & 0.05 & 0 & 0 & 0 & 0.30 & 1.07 & N/A & 0 & 0 & 0 & 261 \\
\hline 9/18/08 & 0 & 0 & 0.10 & 0.15 & 0 & 0.38 & 0 & N/A & 0 & 0 & 0 & 262 \\
\hline 9/19/08 & 2.46 & 2.57 & 0 & 0 & 0 & 0.03 & 0.28 & N/A & 0.03 & 0 & 0 & 263 \\
\hline 9/20/08 & 0 & 0 & 0 & 0 & 0 & 0 & 0 & N/A & 0 & 0 & 0 & 264 \\
\hline $9 / 21 / 08$ & 0 & 0 & 0 & 0.03 & 0 & 0 & 0 & N/A & 0 & 0 & 0 & 265 \\
\hline $9 / 22 / 08$ & 0 & 0 & 0 & 0.03 & 0 & 0 & 0 & N/A & 0 & 0 & 0 & 266 \\
\hline $9 / 23 / 08$ & 0 & 0 & 0 & 0 & 0 & 0 & 0 & N/A & 0 & 0 & 0 & 267 \\
\hline $9 / 24 / 08$ & 0 & 0 & 0 & 0 & 0 & 0 & 0 & N/A & 0 & 0 & 0 & 268 \\
\hline $9 / 25 / 08$ & 0.10 & 0.05 & 0 & 0 & 0 & 0 & 0 & N/A & 0 & 0 & 0 & 269 \\
\hline $9 / 26 / 08$ & 0 & 0.03 & 7.32 & 8.89 & 5.23 & 0.91 & 0 & N/A & 0 & 0.08 & 1.40 & 270 \\
\hline $9 / 27 / 08$ & 0.38 & 0.30 & 0 & 0 & 0 & 0 & 0 & N/A & 0 & 0.20 & 0.05 & 271 \\
\hline $9 / 28 / 08$ & 0 & 0 & 0 & 0 & 0.23 & 0 & 0 & N/A & 0.05 & 0 & 0 & 272 \\
\hline 9/29/08 & 0.03 & 0 & 0 & 0 & 0 & 0 & 0 & N/A & 0 & 0 & 0.03 & 273 \\
\hline 9/30/08 & 0 & 0 & 0 & 0 & 0 & 0 & 0 & N/A & 0 & 0 & 0 & 274 \\
\hline
\end{tabular}


Table 2. Total rainfall, in $\mathrm{mm}$, recorded daily at each of the weather stations. N/A indicates that the station did not collect data that day.-Continued

\begin{tabular}{|c|c|c|c|c|c|c|c|c|c|c|c|c|}
\hline Date & AZ C:05:0031 L & AZ C:05:0031 U & AZ C:13:0365 L & AZ C:13:0365 U & AZ C:13:0006 & AZ C:13:0336 U & AZ C:13:0346 L & AZ C:13:0346 U & AZ B:11:0281 & AZ A:15:0033 & AZ G:03:0072 U & $\begin{array}{l}\text { Year } \\
\text { Day }\end{array}$ \\
\hline $10 / 1 / 08$ & 0 & 0 & 0 & 0 & 0 & 0 & 0 & N/A & 0 & 0 & 0 & 275 \\
\hline $10 / 2 / 08$ & 0 & 0 & 0 & 0.03 & 0 & 0 & 0 & N/A & 0 & 0 & 0 & 276 \\
\hline $10 / 3 / 08$ & 0 & 0 & 0 & 0 & 0 & 0 & 0 & N/A & 0 & 0 & 0 & 277 \\
\hline $10 / 4 / 08$ & 0.79 & 0.79 & 1.27 & 0.97 & 1.12 & 1.55 & 3.56 & N/A & 6.05 & 7.49 & 0.71 & 278 \\
\hline $10 / 5 / 08$ & 0 & 0 & 0 & 0 & 0 & 0 & 0.03 & N/A & 0.05 & 0 & 0 & 279 \\
\hline $10 / 6 / 08$ & 0 & 0 & 0 & 0 & 0 & 0 & 0 & N/A & 0 & 0 & 0 & 280 \\
\hline $10 / 7 / 08$ & 0 & 0 & 0 & 0 & 0 & 0 & 0 & N/A & 0 & 0 & 0 & 281 \\
\hline $10 / 8 / 08$ & 0 & 0 & 0 & 0 & 0 & 0 & 0 & N/A & 0 & 0 & 0 & 282 \\
\hline $10 / 9 / 08$ & 0 & 0 & 0 & 0.03 & 0 & 0 & 0 & N/A & 0 & 0 & 0 & 283 \\
\hline $10 / 10 / 08$ & 0 & 0 & 0 & 0.15 & 0 & 0 & 0.05 & N/A & 0.03 & 0 & 0 & 284 \\
\hline $10 / 11 / 08$ & 0 & 0 & 0.03 & 0.25 & 0 & 0.03 & 0.05 & N/A & 0 & 0 & 0 & 285 \\
\hline $10 / 12 / 08$ & 0 & 0 & 0 & 0 & 0 & 0 & 0 & N/A & 0 & 0 & 0 & 286 \\
\hline $10 / 13 / 08$ & 0 & 0 & 0 & 0 & 0 & 0 & 0 & N/A & 0 & 0 & 0 & 287 \\
\hline $10 / 14 / 08$ & 0 & 0 & 0 & 0 & 0 & 0 & 0 & N/A & 0 & 0 & 0 & 288 \\
\hline $10 / 15 / 08$ & 0 & 0 & 0 & 0 & 0 & 0 & 0 & N/A & 0 & 0 & 0 & 289 \\
\hline $10 / 16 / 08$ & 0 & 0 & 0 & 0 & 0 & 0 & 0 & N/A & 0 & 0 & 0 & 290 \\
\hline $10 / 17 / 08$ & 0 & 0 & 0 & 0 & 0 & 0 & 0 & N/A & 0 & 0 & 0 & 291 \\
\hline $10 / 18 / 08$ & 0 & 0 & 0 & 0 & 0 & 0 & 0 & 0 & 0 & 0 & 0 & 292 \\
\hline $10 / 19 / 08$ & 0 & 0 & 0 & 0 & 0 & 0 & 0 & 0 & 0 & 0 & 0 & 293 \\
\hline $10 / 20 / 08$ & 0 & 0 & 0.03 & 0 & 0 & 0 & 0 & 0 & 0 & 0 & 0 & 294 \\
\hline $10 / 21 / 08$ & 0 & 0 & 0 & 0 & 0 & 0 & 0 & 0 & 0 & 0 & 0 & 295 \\
\hline $10 / 22 / 08$ & 0 & 0 & 0 & 0 & 0 & 0 & 0 & 0 & 0 & 0 & 0 & 296 \\
\hline $10 / 23 / 08$ & 0 & 0 & 0 & 0 & 0 & 0 & 0 & 0 & 0 & 0 & 0 & 297 \\
\hline $10 / 24 / 08$ & 0 & 0 & 0 & 0 & 0 & 0 & 0 & 0 & 0 & 0 & 0 & 298 \\
\hline $10 / 25 / 08$ & 0 & 0 & 0 & 0 & 0 & 0 & 0 & 0 & 0 & 0 & 0 & 299 \\
\hline $10 / 26 / 08$ & 0 & 0 & 0 & 0 & 0 & 0 & 0 & 0 & 0 & 0 & 0 & 300 \\
\hline $10 / 27 / 08$ & 0 & 0 & 0 & 0 & 0 & 0 & 0 & 0 & 0 & 0 & 0 & 301 \\
\hline $10 / 28 / 08$ & 0 & 0 & 0 & 0 & 0 & 0 & 0 & 0 & 0 & 0 & 0 & 302 \\
\hline $10 / 29 / 08$ & 0 & 0.03 & 0 & 0 & 0 & 0 & 0 & 0 & 0 & 0 & 0 & 303 \\
\hline $10 / 30 / 08$ & 0 & 0 & 0 & 0 & 0 & 0 & 0 & 0 & 0 & 0 & 0 & 304 \\
\hline $10 / 31 / 08$ & 0 & 0.03 & 0 & 0 & 0 & 0 & 0 & 0 & 0 & 0 & 0.03 & 305 \\
\hline
\end{tabular}


Table 2. Total rainfall, in $\mathrm{mm}$, recorded daily at each of the weather stations. N/A indicates that the station did not collect data that day.-Continued

\begin{tabular}{|c|c|c|c|c|c|c|c|c|c|c|c|c|}
\hline Date & AZ C:05:0031 L & AZ C:05:0031 U & AZ C:13:0365 L & AZ C:13:0365 U & AZ C:13:0006 & AZ C:13:0336 U & AZ C:13:0346 L & AZ C:13:0346 U & AZ B:11:0281 & AZ A:15:0033 & AZ G:03:0072 U & $\begin{array}{l}\text { Year } \\
\text { Day }\end{array}$ \\
\hline $11 / 1 / 08$ & 0 & 0 & 0 & 0 & 0 & 0 & 0 & 0 & 0 & 0 & 0 & 306 \\
\hline $11 / 2 / 08$ & 0 & 0 & 0 & 0.05 & 0 & 0 & 0.05 & 0.05 & 0.03 & 0 & 0 & 307 \\
\hline $11 / 3 / 08$ & 0 & 0 & 0 & 0 & 0 & 0 & 0 & 0 & 0 & 0 & 0 & 308 \\
\hline $11 / 4 / 08$ & 0.10 & 0.08 & 0 & 0.05 & 0 & 0 & 0.05 & 0 & 0.38 & 0 & 0 & 309 \\
\hline $11 / 5 / 08$ & 0.03 & 0 & 0 & 0.03 & 0.05 & 0 & 0 & 0 & 0 & 0 & 0 & 310 \\
\hline $11 / 6 / 08$ & 0 & 0 & 0 & 0 & 0 & 0 & 0 & 0 & 0 & 0 & 0 & 311 \\
\hline $11 / 7 / 08$ & 0 & 0 & 0 & 0 & 0 & 0 & 0 & 0 & 0 & 0 & 0 & 312 \\
\hline $11 / 8 / 08$ & 0 & 0 & 0 & 0 & 0 & 0 & 0 & 0 & 0 & 0 & 0 & 313 \\
\hline $11 / 9 / 08$ & 0.56 & 0.58 & 2.44 & 2.36 & 2.59 & 0.20 & 0.10 & 0.15 & 2.16 & 1.17 & 2.11 & 314 \\
\hline $11 / 10 / 08$ & 0 & 0 & 0 & 0 & 0 & 0 & 0.03 & 0.03 & 0.03 & 0 & 0 & 315 \\
\hline $11 / 11 / 08$ & 0 & 0 & 0 & 0 & 0 & 0 & 0 & 0 & 0 & 0 & 0 & 316 \\
\hline $11 / 12 / 08$ & 0 & 0 & 0 & 0 & 0 & 0 & 0 & 0 & 0 & 0 & 0 & 317 \\
\hline $11 / 13 / 08$ & 0 & 0 & 0 & 0 & 0 & 0 & 0 & 0 & 0 & 0 & 0 & 318 \\
\hline $11 / 14 / 08$ & 0 & 0 & 0 & 0 & 0 & 0 & 0 & 0 & 0 & 0 & 0 & 319 \\
\hline $11 / 15 / 08$ & 0 & 0 & 0 & 0 & 0 & 0 & 0 & 0 & 0 & 0 & 0 & 320 \\
\hline $11 / 16 / 08$ & 0 & 0 & 0 & 0 & 0 & 0 & 0 & 0 & 0 & 0 & 0 & 321 \\
\hline $11 / 17 / 08$ & 0 & 0 & 0 & 0 & 0 & 0 & 0 & 0 & 0 & 0 & 0 & 322 \\
\hline $11 / 18 / 08$ & 0 & 0 & 0 & 0 & 0 & 0 & 0 & 0 & 0 & 0 & 0 & 323 \\
\hline $11 / 19 / 08$ & 0 & 0 & 0 & 0 & 0 & 0 & 0 & 0 & 0 & 0 & 0 & 324 \\
\hline $11 / 20 / 08$ & 0 & 0 & 0 & 0 & 0 & 0 & 0 & 0 & 0 & 0 & 0 & 325 \\
\hline $11 / 21 / 08$ & 0 & 0 & 0 & 0 & 0 & 0 & 0 & 0 & 0 & 0 & 0 & 326 \\
\hline $11 / 22 / 08$ & 0 & 0 & 0 & 0 & 0 & 0 & 0 & 0 & 0 & 0 & 0 & 327 \\
\hline $11 / 23 / 08$ & 0 & 0 & 0 & 0 & 0 & 0 & 0 & 0 & 0 & 0 & 0 & 328 \\
\hline $11 / 24 / 08$ & 0 & 0 & 0 & 0 & 0 & 0 & 0 & 0 & 0 & 0 & 0 & 329 \\
\hline $11 / 25 / 08$ & 0 & 0 & 0.03 & 0 & 0 & 0 & 0 & 0 & 0 & 0 & 0 & 330 \\
\hline $11 / 26 / 08$ & 3.71 & 4.22 & 4.22 & 5.00 & 3.76 & 2.72 & 2.62 & 2.44 & 12.90 & 17.96 & 23.16 & 331 \\
\hline $11 / 27 / 08$ & 10.11 & 10.39 & 14.38 & 16.36 & 13.13 & 12.07 & 15.54 & 14.35 & 20.78 & 6.15 & 1.60 & 332 \\
\hline $11 / 28 / 08$ & 0 & 0 & 0 & 0 & 0 & 0 & 0 & 0 & 0 & 0 & 0 & 333 \\
\hline $11 / 29 / 08$ & 0 & 0 & 0 & 0 & 0 & 0 & 0 & 0 & 0 & 0 & 0 & 334 \\
\hline $11 / 30 / 08$ & 0 & 0 & 0 & 0 & 0 & 0 & 0 & 0 & 0 & 0 & 0 & 335 \\
\hline
\end{tabular}


Table 2. Total rainfall, in $\mathrm{mm}$, recorded daily at each of the weather stations. N/A indicates that the station did not collect data that day.-Continued

\begin{tabular}{|c|c|c|c|c|c|c|c|c|c|c|c|c|}
\hline Date & AZ C:05:0031 L & AZ C:05:0031 U & AZ C:13:0365 L & AZ C:13:0365 U & AZ C:13:0006 & AZ C:13:0336 U & AZ C:13:0346 L & AZ C:13:0346 U & AZ B:11:0281 & AZ A:15:0033 & AZ G:03:0072 U & $\begin{array}{l}\text { Yea } \\
\text { Day }\end{array}$ \\
\hline $12 / 1 / 08$ & 0 & 0 & 0 & 0 & 0 & 0 & 0 & 0 & 0 & 0 & 0 & 336 \\
\hline $12 / 2 / 08$ & 0 & 0 & 0 & 0 & 0 & 0 & 0 & 0 & 0 & 0 & 0 & 337 \\
\hline $12 / 3 / 08$ & 0 & 0 & 0 & 0 & 0 & 0 & 0 & 0 & 0 & 0 & 0 & 338 \\
\hline $12 / 4 / 08$ & 0 & 0 & 0 & 0 & 0 & 0 & 0 & 0 & 0 & 0 & 0 & 339 \\
\hline $12 / 5 / 08$ & 0 & 0 & 0 & 0 & 0 & 0 & 0 & 0 & 0 & 0 & 0 & 340 \\
\hline $12 / 6 / 08$ & 0 & 0 & 0 & 0 & 0 & 0 & 0 & 0 & 0 & 0 & 0 & 341 \\
\hline $12 / 7 / 08$ & 5.38 & 6.02 & 0.86 & 0.97 & 0.48 & 0.03 & 0 & 0 & 0.63 & 0.53 & 0.15 & 342 \\
\hline $12 / 8 / 08$ & 0.48 & 0.58 & 0.41 & 0.84 & 0.41 & 0.23 & 0.36 & 0.28 & 0.05 & 0 & 0.25 & 343 \\
\hline $12 / 9 / 08$ & 0 & 0 & 0 & 0 & 0 & 0 & 0 & 0 & 0 & 0 & 0 & 344 \\
\hline $12 / 10 / 08$ & 0 & 0 & 0 & 0 & 0 & 0 & 0 & 0 & 0 & 0 & 0 & 345 \\
\hline $12 / 11 / 08$ & 0 & 0 & 0 & 0 & 0 & 0 & 0 & 0 & 0 & 0 & 0 & 346 \\
\hline $12 / 12 / 08$ & 0 & 0 & 0 & 0 & 0 & 0 & 0 & 0 & 0 & 0 & 0 & 347 \\
\hline $12 / 13 / 08$ & 7.92 & 8.08 & 3.15 & 3.66 & 1.37 & 2.62 & 1.50 & 1.42 & 3.45 & 2.18 & 2.77 & 348 \\
\hline $12 / 14 / 08$ & 0 & 0 & 0 & 0 & 0 & 0 & 0 & 0 & 0.03 & 0 & 0 & 349 \\
\hline $12 / 15 / 08$ & 0 & 0 & 1.90 & 2.21 & 2.31 & 3.73 & 3.38 & 2.97 & 6.40 & 4.44 & 5.69 & 350 \\
\hline $12 / 16 / 08$ & 0 & 0 & 0.03 & 0.03 & 0.05 & 1.50 & 0.03 & 0 & 0.99 & 0.33 & 6.71 & 351 \\
\hline $12 / 17 / 08$ & 5.64 & 5.03 & 11.76 & 13.41 & 7.44 & 4.55 & 4.57 & 3.96 & 7.98 & 39.32 & 39.14 & 352 \\
\hline $12 / 18 / 08$ & 0.81 & 0.61 & 2.79 & 3.10 & 2.34 & 4.88 & 5.54 & 5.00 & 7.67 & 8.20 & 3.48 & 353 \\
\hline $12 / 19 / 08$ & 0 & 0 & 0 & 0 & 0 & 0 & 0 & 0 & 0 & 0 & 0 & 354 \\
\hline $12 / 20 / 08$ & 0 & 0 & 0 & 0 & 0 & 0 & 0 & 0 & 0 & 0 & 0 & 355 \\
\hline $12 / 21 / 08$ & 0 & 0 & 0 & 0 & 0 & 0 & 0 & 0 & 0 & 0 & 0 & 356 \\
\hline $12 / 22 / 08$ & 0 & 0 & 3.28 & 2.97 & 4.24 & 2.21 & 1.98 & 1.93 & 1.32 & 2.06 & 0.46 & 357 \\
\hline $12 / 23 / 08$ & 0 & 0 & 1.07 & 0.97 & 1.37 & 0.30 & 0.15 & 0.18 & 3.40 & 3.28 & 0 & 358 \\
\hline $12 / 24 / 08$ & 0 & 0 & 0 & 0 & 0 & 0 & 0 & 0 & 0 & 0 & 0.05 & 359 \\
\hline $12 / 25 / 08$ & 2.13 & 2.18 & 4.39 & 4.11 & 3.25 & 6.96 & 12.42 & 13.08 & 9.17 & 8.84 & 6.99 & 360 \\
\hline $12 / 26 / 08$ & 0 & 0.03 & 0.38 & 0.20 & 0.23 & 0.36 & 0.43 & 0.91 & 0.41 & 0.03 & 0 & 361 \\
\hline $12 / 27 / 08$ & 0 & 0 & 0 & 0 & 0 & 0 & 0 & 0 & 0 & 0 & 0 & 362 \\
\hline $12 / 28 / 08$ & 0 & 0 & 0 & 0 & 0 & 0 & 0 & 0 & 0 & 0 & 0 & 363 \\
\hline $12 / 29 / 08$ & 0 & 0 & 0 & 0 & 0 & 0 & 0 & 0 & 0 & 0 & 0 & 364 \\
\hline $12 / 30 / 08$ & 0 & 0 & 0 & 0 & 0 & 0 & 0 & 0 & 0 & 0 & 0 & 365 \\
\hline $12 / 31 / 08$ & 0 & 0 & 0 & 0 & 0 & 0 & 0 & 0 & 0 & 0 & 0 & 366 \\
\hline
\end{tabular}


Table 3. Vector sums of the sediment-transport proxy variable, $Q p$ (equation 1), by month for each weather station.

[Vector sums are reported as the magnitude of $Q p\left(\mathrm{in} \mathrm{m}^{3} / \mathrm{s}^{3}\right)$ followed by the direction from which this net transport would occur, in degrees. A, These calculations were made irrespective of rain events. $B$, vector sums re-calculated using wind data only from time when sand is assumed to have been dry enough to transport sand. These calculations (in $B$ ) omit wind data collected within 48 hours after a rain event]

$A$

\begin{tabular}{lllllll}
\hline \multicolumn{1}{c}{ Station } & \multicolumn{1}{c}{ Jan-08 } & \multicolumn{1}{c}{ Feb-08 } & \multicolumn{1}{c}{ Mar-08 } & \multicolumn{1}{c}{ Apr-08 } & May-08 \\
\hline AZ C:05:0031 L & 23602,113 & 1034,174 & 3381,185 & 7509,226 & 3076,213 & 2193,204 \\
AZ C:05:0031 U & 35533,131 & 4220,227 & 8192,223 & 28440,233 & 1246,240 & 1196,232 \\
AZ C:13:0365 L & N/A & 2593,162 & 5008,3 & 30345,162 & 5392,179 & 4055,171 \\
AZ C:13:0365 U & N/A & 35537,164 & 54449,140 & 218650,144 & 114910,145 & 96566,145 \\
AZ C:13:0006 & 2008, 104 & 2665,123 & N/A & N/A & N/A & N/A \\
AZ C:13:0336 U & 121610, 68 & 64089,81 & 58197,109 & 220560,159 & 60948,151 & 83669,169 \\
AZ C:13:0346 L & N/A & 30223,250 & 92445,253 & 274710,253 & 68605,252 & 84766,253 \\
AZ C:13:0346 U & 64706, 240 & 40092,237 & 24653,235 & 127980,243 & 21784,237 & N/A \\
AZ B:11:0281 & 1103, 102 & 3742,100 & 3002,268 & 6414,73 & 4064,96 & 702,68 \\
AZ A:15:0033 & 1023,315 & 1157,314 & 1913,353 & 2346,189 & 303,200 & 2090,196 \\
AZ G:03:0072 & 2212,182 & 376,191 & 6429,171 & 12983,188 & 6745,171 & 8953,197
\end{tabular}

\begin{tabular}{llllllll}
\hline \multicolumn{1}{c}{ Station } & \multicolumn{1}{c}{ Jul-08 } & \multicolumn{1}{c}{ Aug-08 } & \multicolumn{1}{c}{ Sep-08 } & \multicolumn{1}{c}{ 0ct-08 } & \multicolumn{1}{c}{ Nov-08 } & \multicolumn{1}{c}{ Dec-08 } & Net vector \\
\hline AZ C:05:0031 L & 87,276 & 2165,256 & 308,189 & 10048,228 & 622,163 & 918,241 & 32164,174 \\
AZ C:05:0031 U & 3741,217 & 5915,239 & 2338,232 & 23400,249 & 2093,224 & 4363,238 & 82308,211 \\
AZ C:13:0365 L & 1446,206 & 75,345 & 559,71 & 6273,134 & 4519,47 & 6212,94 & 45383,152 \\
AZ C:13:0365 U & 59997,148 & 32926,149 & 34728,147 & 124190,133 & 40231,123 & 59420,120 & 858790,142 \\
AZ C:13:0006 & N/A & N/A & N/A & 175,91 & 4090,130 & 2494,91 & 10999,115 \\
AZ C:13:0336 U & 27644,170 & 18910,164 & 19884,173 & 42598,149 & 41264,134 & 94084,112 & 691470,133 \\
AZ C:13:0346 L & 10752,237 & 14434,246 & 18971,256 & 75264,256 & 45624,251 & 62182,246 & 748550,252 \\
AZ C:13:0346 U & N/A & 8548,227 & 1622,246 & 983,178 & 28435,235 & 64495,228 & 381070,237 \\
AZ B:11:0281 & 7725,111 & 6267,113 & 7075,107 & 15267,105 & 2787,99 & 3078,40 & 52521,99 \\
AZ A:15:0033 & 880,199 & 488,225 & 182,248 & 1422,345 & 2041,349 & 1459,258 & 5856,276 \\
AZ G:03:0072 & 6399,198 & 6587,189 & 4501,195 & 6028,186 & 2564,195 & 2940,183 & 65861,187 \\
\hline
\end{tabular}


Table 3. Vector sums of the sediment-transport proxy variable, $Q p$ (equation 1), by month for each weather station.-Continued $B$

\begin{tabular}{|c|c|c|c|c|c|c|}
\hline Station & Jan-08 & Feb-08 & Mar-08 & Apr-08 & May-08 & Jun-08 \\
\hline AZ C:05:0031 L & 21220,110 & 726,145 & 3180,140 & 7552,227 & 1528,204 & 2072,204 \\
\hline AZ C:05:0031 U & 32526,121 & 2279,245 & 7105,222 & 27646,233 & 7640,240 & 11007,232 \\
\hline AZ C:13:0365 U & N/A & 16508,163 & 8228,105 & 15319,151 & 12418,148 & 27301,146 \\
\hline AZ C:13:0006 & 662,131 & 1651,127 & N/A & N/A & N/A & N/A \\
\hline AZ C:13:0346 L & N/A & 19664,259 & 71435,253 & 111500,254 & 60948,253 & 77168,254 \\
\hline AZ C:13:0346 U & 22163,237 & 13404,241 & 23691,236 & 100060,243 & 19292,239 & N/A \\
\hline AZ B:11:0281 & 688,278 & 3327,105 & 1274,221 & 1248,19 & 1470,92 & 972,5 \\
\hline AZ A:15:0033 & 1590,349 & 1147,336 & 1776,353 & 2418,188 & 584,196 & 2068,196 \\
\hline
\end{tabular}

\begin{tabular}{llllllll}
\hline \multicolumn{1}{c}{ Station } & \multicolumn{1}{c}{ Jul-08 } & \multicolumn{1}{c}{ Aug-08 } & \multicolumn{1}{c}{ Sep-08 } & \multicolumn{1}{c}{ Oct-08 } & \multicolumn{1}{c}{ Nov-08 } & \multicolumn{1}{c}{ Dec-08 } & Net vector \\
\hline AZ C:05:0031 L & 133,244 & 1899,271 & 84,79 & 9735,229 & 675,188 & 1083,230 & 26995,169 \\
AZ C:05:0031 U & 1540,213 & 625,218 & 716,227 & 21827,249 & 1639,227 & 4044,247 & 76494,215 \\
AZ C:13:0365 L & 1411,193 & 264,183 & 258,102 & 4203,134 & 4063,48 & 1452,88 & 40262,158 \\
AZ C:13:0365 U & 19439,149 & 18139,149 & 10962,146 & 12527,139 & 8524,121 & 7684,122 & 151870,146 \\
AZ C:13:0006 & N/A & N/A & N/A & 175,91 & 3864,131 & 230,66 & 6419,127 \\
AZ C:13:0336 U & 18124,170 & 10048,170 & 8784,178 & 38151,153 & 35926,136 & 28399,68 & 415870,137 \\
AZ C:13:0346 L & 6928, 238 & 5730,245 & 4105,261 & 20566,252 & 2171,71 & 27646,249 & 374710,254 \\
AZ C:13:0346 U & N/A & 1957,221 & 774,253 & 983,178 & 10677,234 & 255561,230 & 445970,234 \\
AZ B:11:0281 & 984,108 & 1659,107 & 737,116 & 3738,106 & 256,65 & 2982,91 & 13756,97 \\
AZ A:15:0033 & 790,199 & 439,199 & 162,337 & 1351,344 & 2090,345 & 1532,239 & 4837,281 \\
AZ G:03:0072 & 2340, 201 & 3736,194 & 2077,192 & 5641,185 & 1502,192 & 2014,194 & 52188,187 \\
\hline
\end{tabular}


Table 4. Area and volume of sand above the $226 \mathrm{~m}^{3} / \mathrm{s}(8,000 \mathrm{ft} / \mathrm{s})$ stage on sandbars near sites monitored for this project. $A$, topographic surveys of sandbars were conducted several weeks before (February 2008) and several weeks after the March 2008 high-flow experiment (HFE), and again in October 2008, to evaluate changes caused by the high flow. $B$, topographic surveys of sandbars were conducted in October 2008, 7 months after the March HFE.

$A$

\begin{tabular}{|c|c|c|c|c|c|c|c|c|}
\hline Site near sandbar & $\begin{array}{l}\text { Before HFE } \\
\text { February } \\
2008 \\
\text { area }\left(\mathrm{m}^{2}\right)\end{array}$ & $\begin{array}{c}\text { Before HFE } \\
\text { February } \\
2008 \\
\text { volume }\left(\mathrm{m}^{3}\right)\end{array}$ & $\begin{array}{c}\text { After HFE } \\
\text { March } 2008 \\
\text { area }\left(\mathrm{m}^{2}\right)\end{array}$ & $\begin{array}{l}\text { Before HFE } \\
\text { March } 2008 \\
\text { volume }\left(\mathrm{m}^{3}\right)\end{array}$ & $\begin{array}{c}\text { Change in } \\
\text { area }\left(\mathrm{m}^{2}\right)\end{array}$ & $\begin{array}{l}\text { Change in } \\
\text { area (\%) }\end{array}$ & $\begin{array}{c}\text { Change in } \\
\text { volume (m3) }\end{array}$ & $\begin{array}{c}\text { Change in } \\
\text { volume (\%) }\end{array}$ \\
\hline AZ C:05:0031 & 653 & 1,493 & 659 & 1,610 & 6 & 0.9 & 117 & 7.8 \\
\hline AZ C:13:0365 & 1,874 & 3,224 & 1,558 & 3,670 & -316 & -16.9 & 446 & 13.8 \\
\hline AZ C:13:0321 & 6,620 & 4,418 & 8,964 & 11,213 & 2,344 & 35.4 & 6,795 & 153.8 \\
\hline AZ C:13:0336 & 1,353 & 2,475 & 3,103 & 4,705 & 1,750 & 129.3 & 2,230 & 90.1 \\
\hline
\end{tabular}

$B$

\begin{tabular}{|c|c|c|c|c|c|c|}
\hline Site near sandbar & $\begin{array}{c}\text { After HFE } \\
\text { October } 2008 \\
\text { area }\left(\mathrm{m}^{2}\right)\end{array}$ & $\begin{array}{c}\text { After HFE } \\
\text { October } 2008 \\
\text { volume }\left(\mathrm{m}^{3}\right)\end{array}$ & $\begin{array}{l}\text { (Mar. to Oct.) } \\
\text { Change in area } \\
\left(\mathrm{m}^{2}\right)\end{array}$ & $\begin{array}{l}\text { (Mar. to Oct.) } \\
\text { Change in area } \\
(\%)\end{array}$ & $\begin{array}{l}\text { (Mar. to Oct.) } \\
\text { Change in } \\
\text { volume }\left(\mathrm{m}^{2}\right)\end{array}$ & $\begin{array}{c}\text { (Mar. to Oct.) } \\
\text { Change in } \\
\text { volume }(\%)\end{array}$ \\
\hline AZ C:13:0365 & 2,143 & 3,559 & 585 & 37.5 & -111 & -3.0 \\
\hline AZ C:13:0006 & 256 & 444 & 13 & 5.3 & -44 & -9.0 \\
\hline AZ C:13:0321 & 2,889 & 3,904 & -214 & -6.9 & -801 & -17.0 \\
\hline
\end{tabular}


This page was intentionally left blank. 


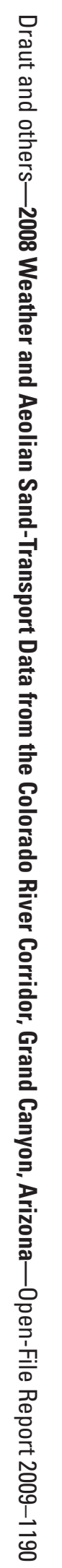

